
FROM MONOLOGUE TO DIALOGUE 
‘To be means to communicate dialogically. When dialogue ends, everything ends.'

M.M. Bakhtin 1984a:252.

Cover illustration: A host reading a request from a listener at the community radio station Pamor in the Parangtritis area south of Yogyakarta, 2002 
V E R H A N D E L I N G E N VAN HET KONINKLIJK INSTITUUT VOOR TAAL-, LAND- EN VOLKENKUNDE

264

EDWIN JURRIËNS

\title{
FROM MONOLOGUE TO DIALOGUE
}

\author{
Radio and reform in Indonesia
}

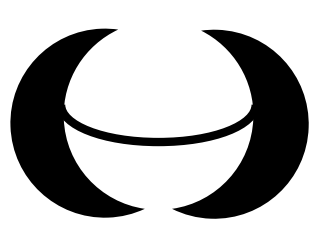

KITLV Press

Leiden

2009 
Published by:

KITLV Press

Koninklijk Instituut voor Taal-, Land- en Volkenkunde

(Royal Netherlands Institute of Southeast Asian and Caribbean Studies)

PO Box 9515

2300 RA Leiden

The Netherlands

website: www.kitlv.nl

e-mail: kitlvpress@kitlv.nl

KITLV is an institute of the Royal Netherlands Academy of Arts and Sciences (KNAW)

Cover: Creja ontwerpen, Leiderdorp

ISBN 9789067183543

(C) 2009 Koninklijk Instituut voor Taal-, Land- en Volkenkunde

No part of this publication may be reproduced or transmitted in any form or by any means, electronic or mechanical, including photocopy, recording, or any information storage and retrieval system, without permission from the copyright owner.

Printed in the Netherlands 


\section{Contents}

I Introduction

Facts and fiction 1

Radio journalism, the public sphere, dialogism 3

Words of gratitude 7

II Reformasi and the medium of radio

Why radio? 9

A short history of Indonesian radio 11

Language and power; New Order's heteroglossia 14

Against monologism; Pasemon and plesetan 17

Reformasi; Carnival and dialogism 20

III Media and publicness

The Depok School and the migration of concepts 25

Habermas, the bourgeois public sphere and the mass media 29

Radio Republik Indonesia; Public radio and the Broadcasting Law 32

Komisi Penyiaran Indonesia; Monitoring the publicness of broadcasting 35

'More than just music'; News radio and segmentation 38

What is new about the news? 43

IV Radio journalism, transition, Indonesianness

The New Order and development journalism 49

Control and contestation 53

KBR 68H and Internews Indonesia; Independent journalism, peace journalism, transparency 57

Indonesia Media Law and Policy Centre; Meta-journalism 65

Friedrich Naumann Stiftung; Contests, inserts and virtual interactivity 68 
$\mathrm{V} \quad$ The actors of interactive radio journalism

The genre of the audience participation programme 79

Hosts addressing their audiences 81

The authority of experts 89

Editors and gatekeepers 92

VI The activity of interactive radio journalism

Multi-sided journalism 98

'News-interaktif-solutif'; From practical solutions to sustainable development 102

'Wandering around the city'; Virtual travel and regional awareness 106

Talk-back radio and the refeudalization of the public sphere? 114

Media literacy 118

VII The discipline of talking

The media of the Bali Post Group 121

Global FM; 'Don't be unwilling to talk' 124

The discipline of talking; 'Global terkini' and 'Jumpa pendengar' 126

Contests for listeners; Awarding 'Social empowerment personalities' 132

VIII Radio komunitas and the imagination of community

Accessibility, participation, self-awareness 142

Aura and the everyday 144

Community radio in Central Java 146

Campus radio in Yogyakarta 149

Grassroots theatre, Brecht; Umfunktionierung and Verfremdung 153

Nostalgia for aura 156

IX Conclusion; Reformasi and the dialogical public sphere

List of abbreviations

Bibliography

Index 


\section{Chapter i}

\section{Introduction}

\section{Facts and fiction}

When journalism has been stifled, literature has to talk. Because journalism talks facts, while literature talks the truth. Facts can be embargoed, manipulated or covered with black ink, but the truth appears automatically, as a reality. Journalism is bound by 1001 restrictions - from business to politics - to present itself, but literature's only restriction is honesty itself. Literary books can be banned, but the truth and literature become one with the air, immune to criticism and irresistible. To cover the facts is a political act, to cover the truth is the most stupid thing on earth that man can do. (Seno Gumira Ajidarma 1997:1.)

According to the Indonesian writer and journalist Seno Gumira Ajidarma (1997:7), 'the truth' that is found in literature functions as a type of 'meta-journalism', revealing the mechanisms behind journalism. Literature would be able to explore and comment on journalism, and other things in life, because it is fiction that is not bound by any rules but the rules of literature itself. In other words, it is literature's relative boundlessness that facilitates the truth to emerge. Journalism, on the other hand, would not be able to comment on itself because it is supposed to be about nothing but facts. Ajidarma (1997:1) rightly points out the irony that these facts, in spite of their alleged nature, actually vary with different political and economic interests.

Ajidarma's anthology of short stories Ketika jurnalisme dibungkam sastra harus bicara ('Literature has to talk when journalism has been stifled', 1997), from which the quote was derived, was published during President Suharto's totalitarian New Order (1967-1998). During this regime, which was characterized by a climate of censorship and self-censorship of the Indonesian press, there was indeed a need for literature to talk and tell the truth. Elsewhere (Jurriëns 2004) I have analysed examples of 'talking' verbal art in West Java during the late New Order, including the television drama 'Inohong di Bojongrangkong' ('The leader of Bojongrangkong', a fictional West Javanese village), the musical genre of Pop Sunda (Sundanese pop music) and the radio programme 'Dongeng plesetan' ('Tales of punning'). These media expressions addressed the issue of the globalization of West Javanese society by providing 
artistic meta-commentary on the role and impact of the media, amongst others. During the same period, journalists also made use of literary techniques such as allusion and parody to inform people about politically sensitive issues in an indirect manner, relatively safe from censorship and bans.

This is not to deny that literature, apart from containing 'the truth', can also become a vehicle for 'facts' in Ajidarma's sense. For instance, the Suharto regime exercised propaganda and deliberately engaged in the 'aestheticization of politics' (Benjamin 1977:42) by using attractive and thus convincing verbal art such as wayang golek (wooden puppet theatre) (Weintraub 2004) rather than, or in addition to, less alluring information genres such as news bulletins. This book seeks to demonstrate that 'the truth' and 'facts', rather than being universal and unchangeable, take different forms under different social and historical circumstances, and that contemporary Indonesian journalism also has the capacity to be 'honest' and meta-journalistic.

The book will focus on changes and continuities in the field of journalism since the 1998 fall of Suharto and start of the process of social and political reform known as Reformasi. Although this period of 'transition' has left many economic, legislative and other major problems unresolved, it has certainly contributed to a greater freedom of speech in Indonesia. Ironically, this new freedom seems to have deprived some verbal art of its socio-critical vigour. For example, West Javanese audiences have complained that media productions like 'Inohong di Bojongrangkong', Pop Sunda and 'Dongeng plesetan' have outlived their social and artistic ideals and are now more concerned with their commercial viability and marketing strategies. At the same time, however, exciting developments have taken place elsewhere in the creative field. In Indonesian literature, for instance, young female authors have given expression to Reformasi as a kind of Bakhtinian 'carnival' by giving unconventional attention to the body and sexuality, thereby undermining the traditional canon and reversing the hierarchy of the literary establishment.

New forms of creativity can also be found in the field of journalism. During the New Order, the officially approved journalism was the regime's interpretation of development journalism - which, in effect, was government propaganda - although journalists also attempted to make readers and audiences read or listen 'between the lines' by using allusive, quasiliterary journalistic devices. Since Reformasi, journalists have received the legal and political space also to develop or re-develop other concepts of journalism, including meta-journalism. This emancipatory tendency has been accompanied and sometimes stimulated by the development of various new communication technologies, such as satellite systems and the Internet. Returning to Ajidarma, one could say that in an era in which Indonesian journalism is stifled to a lesser extent, it is much more capable to speak for itself. Unfortunately, the other, negative side of Indonesia's new freedom of speech 
is that journalists have been increasingly confronted with violent threats from militant groups in society, and often struggle to live up to the ethical standards of their profession.

Radio journalism, the public sphere, dialogism

This book will specifically focus on contemporary Indonesian radio journalism, which has been shaped by, and made significant contributions to, the socio-political process that led to the fall of Suharto and initiated the call for reform. Its dynamics have been influenced by the end of state-ruled Radio Republik Indonesia's (RRI, Radio of the Republic of Indonesia) monopoly on the production of news programmes in 1998. This officially allowed commercial and other non-governmental radio institutions to develop their own journalistic ideas and practices. Some of these institutions had already tested the limits of New Order state control by combining news with genres less vulnerable to censorship, such as talk shows, music programmes and radio plays.

I will discuss how the radio institutions in interaction with their audiences have attempted to envision and realize a virtual, but at the same time very concrete, space for people to meet and publicly discuss matters considered relevant to the society in which they live. This Reformasi-type of 'radio-active' publicness will be compared with Jürgen Habermas' notion of the 'bourgeois public sphere'. Although I will also analyse radio programmes on general social issues, special attention will be paid to journalistic ideas and practices with a meta-journalistic character, which provide a direct sense of the intensive process of both journalists and audiences exploring and negotiating the boundaries of the new press freedom.

I will also argue that the new ideas and practices, in triggering audience engagement in journalistic affairs, constitute a reaction against the New Order official culture of 'monologism' - which was precisely aimed at keeping audiences at a distance - and share characteristics with a Bakhtinian type of 'dialogism'. This dialogism is broader and goes beyond mere participation in 'normal' dialogue, as it also concerns the 'ideological becoming' of the participants involved. Although dialogism can manifest itself in literally dialogic conversation, here it also refers to journalistic concepts, programme genres and institutional organization forms specifically constructed to enhance media literacy and thus ideological awareness of the public. The whole process of Reformasi could not exist without these concepts, genres and organization forms, and their analysis will make real and tangible what is meant by the seemingly vague and broad ideas of freedom of speech, social reform and democracy, which have been so often and loudly propagated in Indonesia in recent years. 


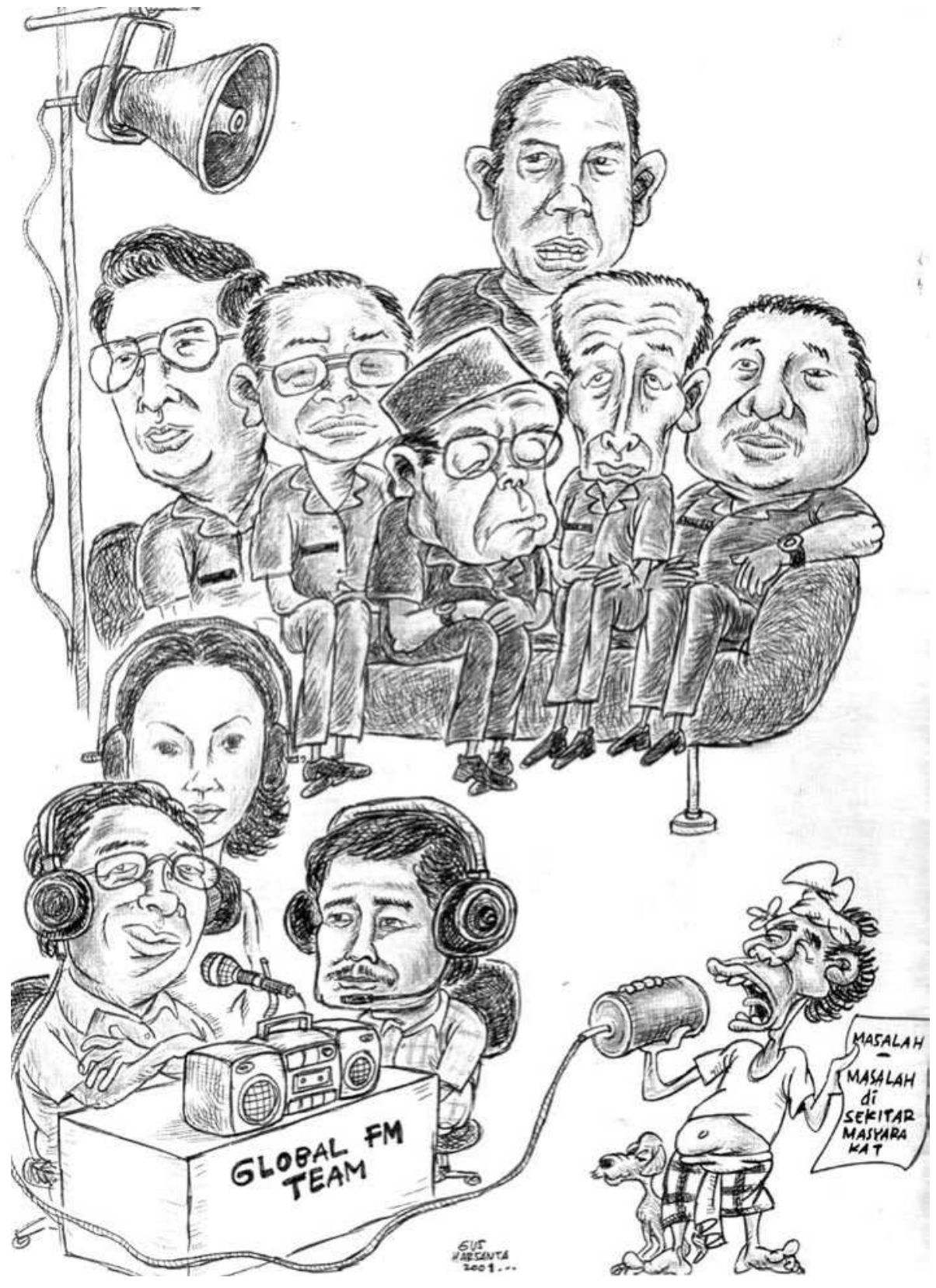

The Balinese radio station Global FM presents itself as the mediator of dialogue in the public sphere, 2001 
I will try to promote dialogue myself by identifying, respecting and talking back to the sources that informed this book. Part of this approach is that I will restrict the use of the omniscient narrator style and avoid irony altogether. Even in times of postmodern and postcolonial concerns with 'the Other', Western scholarship on Indonesia sometimes still displays a rather distanced, cynical or patronizing view of the country and its people, or merely reads as an intellectual exercise for the author's own sake. With its focus on media and everyday life, this book is also meant to increase the acceptance and appreciation of cultural studies among Indonesia scholars.

I will focus, to a certain extent, on the success stories of Reformasi in order to provide a clear picture of the motivations and achievements of the actors behind the process. In spite of an academic trend to downplay the process of reform and to over-emphasize the continuities between the New Order and post-New Order periods, and in spite of the many problems Indonesia still has to deal with - environmental destruction, human rights violations, the journalistic problems mentioned earlier - the one achievement that has been outstanding and cannot be denied is the enhanced freedom of the media, including radio.

This book consists of nine chapters. Chapters II and III explain the political and historical macro-contexts of late- and post-New Order radio journalism, and include an exploration of notions such as Reformasi, dialogism and public sphere. Chapters IV to VIII analyse the intermediate and micro-levels of specific institutions, journalistic concepts and programme genres. The chapters discuss different groups of actors in Indonesian radio journalism and show that the boundaries between those groups have been questioned and undermined in times of reform. Chapter IX, the concluding chapter, summarizes the contributions of these groups to Reformasi.

Chapter II will provide a short historical overview of the development of the medium of radio in Indonesia. It will also introduce the Bakhtinian concepts of 'heteroglossia', 'carnival' and 'dialogism' in order to describe the cultural climates in which radio developed during the New Order and Reformasi. I will argue that alternative creative forces during the New Order were in constant heteroglossic interaction with the culture officially approved and propagated by the government. The alternative forces paved the way for Reformasi, which in Bakhtinian carnivalesque manner has partially succeeded in reversing power structures in society. Actors in the field of (radio) journalism have attempted to provide a dialogic answer to the monologism of New Order's official culture by engaging audiences in news production and enhancing their media literacy and ideological awareness.

Chapter III will analyze how radio journalism, taking advantage of the reduction of state power in the wake of Suharto's fall, has contributed to the creation of a public sphere where Indonesian civil society is able to manifest 
itself. I will discuss several relevant sources that have introduced the idea of the public sphere in the Indonesian media and compare their approaches with those of Habermas, arguably the most original thinker on the public sphere. I will address RRI's attempts to change from a state institution to a formally public organization, but also identify 'publicness' as a value rather than a media category. In fact, I will demonstrate that media segmentation and commercialism have been crucial factors in spreading ideas and practices of publicness in the Indonesian radio scene.

Chapter IV will discuss the transition from the New Order interpretation of development journalism and control of media institutions and professional organizations, to post-New Order radio institutions and journalistic concepts that partly live up to Habermas' idea of the bourgeois public sphere. At the same time, I will provide a critique of their 'bourgeoisness' and also put the local character or 'Indonesianness' of Reformasi into perspective by demonstrating the influence of foreign media organizations and non-governmental organizations (NGOs) on the restructuring of the Indonesian media landscape.

Chapter V will explore a specific genre of radio journalism, the interactive current affairs talk show, which has a highly dialogic character in at least a literal sense. Several of the key actors in the post-Suharto radio-active public sphere will be identified, including hosts, reporters, invited experts, listeners, editors and gate-keepers. I will also explain how the genre can function as a so-called 'oppositional' public sphere, which - unlike Habermas' bourgeois public sphere - is oriented towards the process rather than the outcome of discursive interchange.

Chapter VI will focus on the discursive and practical consequences or impact of the interactive radio shows. It will discuss how interactivity has contributed to the development of the concept of 'multi-sided journalism' as a specific manifestation of Bakhtinian dialogism and an alternative to New Order's monological journalism. It will also identify how interactivity has provided solutions to practical problems ranging from relatively small affairs such as car thefts to more complex issues such as sustainable development. Finally, it will analyse the impact of the interactive shows on listener identity and 'ideological becoming', particularly in terms of regional awareness and media literacy. At the same time, it will illustrate that Habermasian fears of the 'refeudalization' of the public sphere are certainly not without grounds in an Indonesian media landscape where commercial and ideological interests often clash with the interests of the public.

Chapter VII will specifically focus on the role of listeners participating in interactive radio discourse. The case of the commercial news station Global FM in Bali will illustrate that listeners in post-Suharto Indonesia have not only been invited and taken the opportunity to talk about social and political 
affairs, but also about the rights and responsibilities of the actors involved in public discourse, including the radio listeners themselves. Their conversations with hosts, reporters, experts and other participants are not only dialogues in a literal sense, but also in terms of Bakhtin's 'ideological becoming' or Ajidarma's meta-journalistic 'truth'.

Chapter VIII, the chapter before the Conclusion, is about so-called community radio, which constitutes a 'third way' alternative to both government and commercial radio. In community radio, audiences have the opportunity not only to participate in radio discourse and programme production, but also to get involved in media management and ownership. I will argue that community radio completely reverses traditional, hierarchical relations in radio communications and comes close to Bertolt Brecht's ideal of Umfunktionierung, or the 'refunctioning' of radio into a genuinely 'two-way' medium. At the same time, I will demonstrate that community radio is not necessarily more public or dialogic than government or commercial radio, but may in fact hide the ideological role of mediation and represent a false nostalgia for the 'aura' of unmediated communications.

\section{Words of gratitude}

This book is based on a diversity of sources, including scholarly literature, personal interviews and recordings of radio programmes. The majority of the programmes date from 2001 and 2002, and include genres such as news bulletins, live reports, interviews, talk shows, features and editorials. The programmes were produced and broadcast by radio institutions in or near the capitals of six Indonesian provinces - Jakarta (Special Capital District of Jakarta), Bandung (West Java), Yogyakarta (Special District of Yogyakarta), Surabaya (East Java), Tabanan (Bali) and Padang (West Sumatra).

I conducted six months of field research between 2001 and 2003 as part of my affiliation as postdoctoral fellow to the research project 'Indonesian Mediations; The Imaging and Imagining of Community in Post-Suharto Indonesia' at Leiden University. This project was part of the Netherlands Organization for Scientific Research (NWO) and Royal Netherlands Academy of Arts and Sciences (KNAW) research programme 'Indonesia in Transition'. I received additional funding for field research from the Netherlands Foundation for the Advancement of Tropical Research (WOTRO). I did part of the editing when I was a research fellow at the International Institute for Asian Studies (IIAS), Leiden, in early 2008. I wish to express my gratitude to my dearest colleagues from the Indonesian Mediations project - Patricia Spyer, Ben Arps, P.M. Laksono, Emma Baulch, Katinka van Heeren, Wiwik Sushartami and Jos Janssen - the Indonesia in Transition programme man- 
ager Henk Schulte Nordholt, and my colleagues from the School of Asian, African, and Amerindian Studies (CNWS) and IIAS for their kind support.

After being appointed as lecturer in Indonesian Language and Culture at The University of New South Wales in Canberra (UNSW@ADFA) in 2004, I continued working on the book with generous financial support from the university. Many thanks to Minako Sakai, Paul Tickell, Ida Nurhayati and other staff at UNSW@ADFA for hiring me, introducing me to the Australian academic world and making me feel at home. UNSW@ADFA has proved to be a relatively secure and peaceful place for academics to develop their teaching, thinking and writing on a continuous basis, without being disturbed too much by the bureaucratic and competitive demands of the contemporary academic system. The city of Canberra has also provided a healthy natural and social environment, which completely undermines the tired cliché of the urban capital that forces people into hasty, consumerist lifestyles.

Special acknowledgements are due to the scholars, media practitioners and institutions in Indonesia who helped me with the research, particularly Veven Sp. Wardhana, Masduki, Errol Jonathans, Hinca I.P. Pandjaitan, Christiana Chelsia Chan, Jaringan Radio Komunitas Yogyakarta, Global FM, Suara Surabaya, Unisi, Mara, Kantor Berita Radio 68H, Internews Indonesia, the Friedrich Naumann Stiftung and the Indonesia Media Law and Policy Centre. I dedicate this book to them as an expression of my admiration for their creative and often courageous work. Finally, my sincerest regards to my wife, daughter, family, extended family and friends, for all their love and support. 


\section{Chapter iI}

\section{Reformasi and the medium of radio}

This chapter will introduce the two key themes of this book: radio and Reformasi. The first part of the chapter will provide a working definition of Reformasi and address several cultural-historical factors that contributed to the role of radio as a medium of socio-political reform. These factors include the medium's long history and wide availability in Indonesia. The second part will give a conceptual analysis of Reformasi and explain how - rather than why - radio journalism has contributed to reform.

As Reformasi can only be understood in relation to the regime to which it was opposed, the second part will first give a picture of the cultural climate during the New Order. Using the Bakhtinian metaphor of 'heteroglossia', it will describe the tension and interaction between the official culture promoted and propagated by the Suharto government on the one hand, and the alternative, unofficial cultural practice in society on the other. A second Bakhtinian idea, 'carnival', will be introduced to illustrate how the forces that were present below the surface of officialdom during the New Order have been released during Reformasi. Finally, a third Bakhtinian idea, 'dialogism', will be used as a concept for the analysis of the specific way contemporary radio journalism has attempted to break with the monologism of official New Order culture, namely by engaging audiences and making them medialiterate and ideologically aware.

\section{Why radio?}

In historical, sociological and political studies on Indonesia, Reformasi is usually described as a socio-political process aimed at ending malpractices associated with Suharto's New Order regime - such as the vices represented by the popular acronym KKN, which stands for korupsi, kolusi dan nepotisme ('corruption, collusion and nepotism') - and introducing social, political, economic and cultural reform towards a more open and democratic society (Schwarz 2004:xiii-xiv, 308-10). The process was initiated by oppositional groups during the late New Order and officially sanctioned by the political 
successors of Suharto. The urge for reform was strengthened by the economic crisis that had severely hit Indonesia and the rest of South-East Asia since mid-1997 (Schwarz 2004:337-48).

The most visible and persistent social actors calling for reform were the students (Schwarz 2004:354-8), while the main channel for expressing the need for change were the audio-visual media. After the step-down of Suharto, the media and other physical or virtual meeting places have remained a central institutional pillar on which Indonesia's public sphere 'under reform' is based. Thoughts on Reformasi have been expressed and debated by individuals and groups in public spaces such as university campuses and warung (food and coffee stalls), during mass manifestations such as rallies and demonstrations, and in all types of political, religious or social organization. The media that have been used for the dissemination of reformist ideas include newspaper articles, radio and television programmes, Video Compact Disc (VCD) recordings, mobile phone conversations, e-mail messages and Internet websites, and works of art such as literary writings, paintings, sculptures, music concerts and theatre performances (Spyer et al. 2002:177-82). The Reformasi goals of curbing government interference in and control over society, and enhancing people's freedom of speech and organization, are served not only by specific media content, but also by the very facilitation of physical and virtual forums for ordinary people to express and distribute their ideas in public.

Quantitative data suggest that radio was the most popular medium towards the end of the Suharto regime. According to figures of Badan Pusat Statistik (Indonesian Central Agency for Statistics), in 199569.4 per cent of the 45,653,084 Indonesian households owned a radio set. On the assumption of an average of five users per set, there would have been an audience of more than 158 million radio listeners (Hinca I.P. Pandjaitan et al. 2000:14). The same agency calculated that 43.4 per cent of the households owned a television set, which, on the same assumption of five users per set, implied an audience of more than 98 million television viewers, while the total readership of newspapers and magazines was estimated to be around 72 million (Hinca I.P. Pandjaitan et al. 2000:14). Radio's popularity and strategic and influential role as a channel of reform is due to features that are partly technological in nature and partly cultural - referring to the specific ways in which the medium has been explored and exploited in Indonesia - such as the orality and aurality of radio programmes, the relatively low price and portable size of radio receivers, the high speed and large reach of broadcast transmission, and the possibility for listeners to interact in on-air discourse (Masduki 2001:1-8).

Due to the aurality of radio programmes and the inexpensiveness and portability of radio receivers, radio can be enjoyed by different groups in different localities, including illiterate people in the remotest of sites, who do not have access to the print media or other information and entertainment 
sources. Radio does not only have a large reach, but is also faster in disseminating information than most other media due to the relatively straightforward production process of radio broadcasts. Finally, due to the ambient character of radio sounds, radio listeners - unlike the consumers of visual or audio-visual media such as newspapers, television programmes or Internet websites - do not have to situate themselves around and focus their attention on a piece of media equipment, but have the flexibility to engage in other activities while receiving the media content, such as driving a car, performing household duties or working in a shop (H.A. Muis 1997:23).

Due to its specific production, transmission and reception facilities, and significant in the context of Reformasi calls for regional autonomy, Indonesian radio has become a source of local information and entertainment and a means of strengthening people's civil awareness and local or regional cultural identity. Due to its connectivity with the print media, telephone and the Internet, Indonesian radio has also become interactive, enabling listeners to become listener-participants and contribute to programme content and broadcast production (Errol Jonathans 2000:36-7). This blurring of the boundaries between production and reception has become a further stimulus for the local or regional outlook and aspirations of radio stations in the Indonesian villages, cities and provinces.

Because of its specific features, either of an Indonesian or a more general nature, radio has obtained an aura of aural omnipresence. Paradoxically, its very omnipresence has made radio a medium too common or intangible to be noticed. As a consequence, it has been called 'the forgotten medium' (Pease and Dennis 1995) or 'the invisible medium' (Lewis and Booth 1989) in several of the relatively few non-technical publications on radio. Radio deserves better, as it was not only the first electronic mass medium in human history, but it also served as a model for the technology and cultural practices on which other, more recent media are based, such as television and the Internet. Again, it needs to be stressed that the role of radio in contemporary Indonesia is not the product of technological development as such, but builds on changes in the cultural use and socio-political function of the medium since its first introduction in the Netherlands East Indies. If radio is not to be forgotten, Indonesian radio deserves attention in particular, because of its influential role in Indonesian social and political history, including the struggle for Independence of the 1940s.

\section{A short history of Indonesian radio}

The first radio society in the Netherlands East Indies was the Bataviaasche Radio Vereeniging (BRV, Batavian Radio Society), which was founded in 
1925, only six years after the world's first music broadcasts. Before the Second World War, the radio scene in the Netherlands East Indies was heterogeneous, including government radio as well as private radio, and Dutch stations as well as autochthonous ones. The radio scene became centralized in 1942, when the Japanese occupation forces placed all radio stations under the control of their Propaganda and Information Department. This early history of radio in Indonesia has been well documented. ${ }^{1}$ Most references on Indonesian radio mention the role of the medium in broadcasting the Declaration of Independence, 17 August 1945.

On the evening of 17 August 1945, the Indonesian Republicans managed to elude Japanese control of the Jakarta Hoso Kyoku station and broadcast the Declaration of Independence read by Sukarno earlier that morning. The following day a crackling broadcast - in Indonesian, with an English translation - was beamed around the country and around the globe from Bandung where young Republicans had hooked the local radio into the Central Telegraph Office's shortwave transmitter, telling the world that Indonesia was of age. (Sen and Hill 2000:81-2.)

Indonesia would become known as the 'microphone republic' with Sukarno, alias the penyambung lidah rakyat ('the people's tongue') as its first president (McDaniel 1994:214-5). During Sukarno's Old Order (1949-1965) regime, Radio Republik Indonesia (RRI) had a monopoly on radio broadcasting and together with newspapers and later television was an important tool for nation building. During Suharto's New Order, RRI retained its monopoly on news production but lost its popularity to the hundreds of private radio stations that had been officially allowed to become its competitors. After the fall of Suharto in 1998 and during the successive era of social and political reform (Reformasi), regulations to obtain broadcasting licences relaxed and the number of private radio stations in Indonesia skyrocketed to more than one thousand (Hinca I.P. Pandjaitan et al. 2000:15). The 2002 Undang-Undang Penyiaran or 'Broadcasting Law', particularly articles 13 (paragraph 2) and 21 to 24 , officially accepted community radio as a third category besides government and commercial radio.

Other media legislation of the Reformasi era, the Ministerial Decree of 5 June 1998 issued by Minister of Information Yunus Yosfiah, offered an important incentive for the development of radio journalism, as it allowed private stations to produce their own news programmes (Samuel 2002:318; Sen 2003:585). Talk-back shows on current affairs, which during the late New Order played an important role as alternative news bulletins on private radio, 
gained popularity as the Reformasi genre par excellence, where ordinary listeners could give expression to their new freedom of speech. The Ministerial Decree also allowed the relay of programmes from international stations such as BBC World Service, Voice of America, Radio Australia, Radio Nederland and Deutsche Welle, while it reduced the number of news broadcasts that commercial stations were obliged to relay from RRI from eighteen to four times a day. Finally, the Ministerial Decree made an end to the status of standard Indonesian as the only official broadcast language and sanctioned a practice that had already been much in use, namely broadcasting in regional languages and local dialects (Hinca I.P. Pandjaitan 2002:4-5).

Although private radio stations demanded and anticipated the right to produce their own news programmes many years before the fall of the New Order, for many of them radio journalism - that is, journalism that suits the medium of radio - is still a new phenomenon. Being aware of and having to cope with their lack of financial means and human resources, they rely on support from the local print media, some of the few local radio stations with sufficient resources or longer tradition in news provision such as RRI, Suara Surabaya, Mara and Unisi, or international institutions such as Internews and the Friedrich Naumann Stiftung. The support they receive from these organizations includes broadcasting equipment, news programmes for relay, and training courses in journalism.

The growing number of radio stations that dedicate themselves to news and information that is either relayed or self-produced is not only the result of new policies and legislation, or the zealous pursuit of Reformasi ideals, but is also inspired by business interests. These interests are served by and have given shape to the commercial strategy of segmentation, which is the central force behind the structure of the contemporary Indonesian private radio scene. Segmentation means that stations attempt to distinguish themselves from their competitors by specializing in specific broadcast style and content. In this way, they try to attract precise parts or 'segments' of the audience, whose needs and interests have been partly created by the radio stations themselves.

Indonesian radio knew segmentation as early as the 1930s. That was the period of the so-called 'eastern' radio stations or radio ketimuran, private stations monitored by Dutch colonial rule and catering for an autochthonous market (Samuel 2002:305). Segmentation highly increased in the 1980s, when stations began to broadcast on FM and had to fight for a profitable share of the overcrowded media market (Lindsay 1997:118-9). Nowadays, Indonesia counts more than 1,000 officially registered private stations, which create their own segments by focusing on themes as diverse as current affairs, business information, pop music, jazz, youth culture, regional identity, women's affairs, humour and religion (Jurriëns 2004:58-9). Chapter III will describe in 
detail how this type of market segmentation has provided the macro-structural context for the development of contemporary Indonesian radio journalism. The remainder of this chapter will provide a conceptual analysis of the more general cultural climates of the New Order and Reformasi.

\section{Language and power; New Order's heteroglossia}

As mentioned before, the dynamics of Reformasi, including its 'radio-activity', cannot be understood without a picture of the cultural climate it developed in and reacted against, that of the New Order. New Order's cultural climate provided a multi-layered picture, with one layer of official culture approved and propagated by the government and the bureaucracy, and another layer of counter-culture produced by artists, intellectuals, youth, workers and other groups in civil society. The official culture aimed at controlling society and had homogenizing effects. The counter-culture displayed diversity and aimed at self-expression, liberation and the subversion of the restrictive official system. In order to disclose the tension and interaction between the two layers as well as the differences and continuities between the cultural climates of the New Order and Reformasi, I will use the Bakhtinian concept of heteroglossia.

In an article on the creation of Malay and Dutch in the Netherlands East Indies, Henk Maier (1993) showed how heteroglossia applied to an earlier period of Indonesian history. Maier argued that initially a linguistic heteroglossia existed in the Indies, or

a complex interaction of utterances, discourses, speech-genres, 'languages' which - far from being unitary, far from circling around generally accepted centres of authority - formed a continuum of mostly spoken forms, in a number of not very clear defined domains and a great amount of variation (Maier 1993:47).

Since the nineteenth century, the Dutch colonial system attempted to control the centrifugal forces in society and create discursive uniformity through administration, literacy, education and print. As a result, Malay, Dutch, Javanese and several other languages became standardized and 'heteroglossia was transformed into polyglossia' (Maier 1993:49, 56).

Maier (1993:54) acknowledged, however, that the colonial centripetal forces of standardization and unification could never entirely stop heteroglossia from pervading everyday discourse. In similar vein, I argue that in New Order Indonesia the monologism of the official bureaucracy never succeeded in fully controlling or destroying the diverse and centrifugal dynamics of civil society. In fact, the New Order situation could be seen as an example of heteroglossia par excellence, in which centrifugal forces existed 
and progressed amidst and due to their interaction with centripetal forces. According to Bakhtin himself

the centripetal forces of the life of language, embodied in a 'unitary language', operate in the midst of heteroglossia. [...] this stratification and heteroglossia, once realized, is not only a static invariant of linguistic life, but also what insures its dynamics: stratification and heteroglossia widen and deepen as long as language is alive and developing. Alongside the centripetal forces, the centrifugal forces of language carry on their uninterrupted work; alongside verbal-ideological centralization and unification, the uninterrupted processes of decentralization and disunification go forward. (Bakhtin 1981:271-2.)

In other words, the New Order was characterized by a dynamic interaction between the monologism of official culture and the heteroglossia of society rather than a static condition of monoglossia or polyglossia, or one or more stable, unified languages and social systems (Morris 1994:248). One source of information that provides concrete examples of monologism and heteroglossia during the New Order is the edited volume Bahasa dan kekuasaan ('Language and power', Yudi Latif and Idi Subandy Ibrahim 1996). The volume contains analyses of discursive practices that can be regarded as metaphors or metonyms for developments in the wider field of Indonesian culture before Reformasi.

Virginia Matheson Hooker, for instance, analysed the language used by Suharto in his annual speeches to commemorate Indonesian Independence Day, 17 August. According to Matheson Hooker (1996:71; see also Matheson Hooker 1993:284), the New Order speeches were'restrained, planned, directed and directing, leaving the listeners at a distance, not being negotiable through dialogue or questions'. Their style was illustrative of New Order's grip on Indonesian cultural life in general.

In his landmark monograph on Indonesian television, Philip Kitley (2000) specifically addresses the New Order control of journalism in the electronic media. According to Kitley (2000:202), the news on state Televisi Republik Indonesia (TVRI, Television of the Republic of Indonesia), which was the only 'hard' news available on Indonesian television for more than 35 years (1962-1998), constituted a ritual to 'naturalize hierarchy and the controlling knowledge, authority, and social commitment of state officials'. Similar to the news on state radio, the prime focus and bulk of broadcasting time was on the president and other high officials conducting ceremonial activities such as meetings and visits. Ordinary people were represented in a passive way, only there to confirm the authority of the officials and the existing power hierarchy in society, while the mediating role of TVRI and its journalists was effaced as much as possible (Kitley 2000:193-204).

Several scholars, including Matheson Hooker (1993:285-8) and James 
Siegel (1986), who base themselves on the work of Benedict Anderson - one of the pioneers in thinking about the relationship between language and power in Indonesian studies - have explained New Order's monologism with its distancing, homogenizing and controlling impact on society in terms of 'kramanization'. Kramanization refers to the use of speech levels in Javanese, in which, very roughly, krama is the 'higher' level that is used by speakers with speech partners they are less familiar with, or who have a higher social status than themselves, and ngoko the 'lower' level that is used by speakers with speech partners they are familiar with or who have a lower social status than themselves. In Anderson's (1990:142) view, standard Indonesian is analogous to krama, while bahasa Jakarta ${ }^{2}$ has developed into the Indonesian equivalent of ngoko. Anderson (1990:144-51) uses the metaphors of ngoko and krama as he believes that the formalization and homogenization of Indonesian language and culture is due to their 'Javanization' or submission to 'Javanese modalities' and the 'Javanese mind'.

It cannot be denied that Sukarno, Suharto and many other high officials in post-colonial Indonesia were from Javanese descent and had a preference for using Javanese symbols to exercise power, control society and privilege the Javanese to a certain extent. However, I consider the search for and display of power symbols as a tendency inherent to virtually any bureaucracy in the world rather than a typical manifestation of Javanese feudalism. The problem is that Anderson's characterization is, if not essentialist, at least a generalization. If formal Indonesian was Javanized, why did so many Javanese flee from it and take refuge in their own, intimate mother-tongue - which is Javanese, with or without speech-levels - similar to other ethnic groups taking refuge in their local or regional mother tongue? And why did many artists and intellectuals employing counter-cultural strategies during the Suharto regime have a Javanese cultural background (Mochtar Pabottingi 1996:159)?

Genres such as the presidential Independence Day speeches and the TVRI and RRI news bulletins strongly controlled the working conditions of media producers and the viewing experiences and life perceptions of audiences, but they did not depict the complete picture of everyday reality during the New Order. It would be naïve and untrue to suppose that all the political statements and cultural policies of high officials were received and accepted at face value, and hardly underwent any distortion or deconstruction by the Indonesian public. In fact, society questioned, reversed and undermined

2 Bahasa Jakarta incorporates elements from bahasa prokem (youth language), bahasa Betawi (the language of the autochthonous population) and other regional and foreign languages, see Loven (2003:138-43) for a detailed description. According to Anderson (1990:142), bahasa Jakarta, with its 'intimate, jazzy, cynical character' constitutes a 'satisfying counterpoint to the formal, official language of public communication'. 
preferred readings and hierarchical structures through literary strategies and other cultural means.

\section{Against monologism; Pasemon and plesetan}

Mochtar Pabottinggi (1996:156-8), in his contribution to the Bahasa dan kekuasaan volume and in reaction against Anderson's argument of the kramanization of Indonesian language and society, gave concrete examples of artists, academics, religious groups and youth who rejected elitism or 'politesse' in language use. One of his examples was the use of bahasa prokem, a colloquial language especially popular among the Jakartan youth and characterized by specific infixes (-ok), suffixes (-in, used with transitive verbs), particles (sih, dong, kok for different forms of emphasis), personal pronouns (gue [I], lu [you]) and abbreviated forms (reduction of me- with transitive and intransitive verbs) (see Prathama Rahardja and Chambert-Loir 1990). According to Pabottinggi (1996:157), this type of counter-strategy reflected people's awareness of the ideological character of (New Order) discourse.

Intellectuals are also aware of language as discourse, that is, they are aware of language practices that systematically privilege certain parties, while setting aside other parties. The sharper the reasoning skill of an intellectual, the stronger [s] he will reject elitism or 'politesse' in language use - a practice that actually often hides social evils. Just ask our students what they believe the term 'to be pacified' [a euphemism for 'to be put in jail'] means; what they think of the jargon/song 'Tomorrow is full of hope' [a nationalistic song]; or what their opinion is about the city of Jakarta being bombarded with posters that carry the entirely bombastic 'Magical Seven' slogans [the 'Saptamarga' military oath about the seven duties of the Armed Forces, for instance]. (Mochtar Pabottinggi 1996:157.)

A beautiful essay about the dynamics of the relationship between New Order's official culture and the heteroglossia of creative forces in society is Goenawan Mohamad's 'Kesusastraan, pasemon' ('Literature, pasemon', 1993). ${ }^{3}$ The central concept of Mohamad's essay is pasemon, which means 'a facial expression that shows, without any words, an attitude at a particular moment' (Goenawan Mohamad 1993:117). It can also mean 'analogy' (kias) or 'allusion' (sindiran).

3 Mohamad's essay is based on a speech he gave in Leiden, 25 May 1992, after becoming the first person to receive the Professor Teeuw Award. This award is named after Hans Teeuw, who held the chair of Indonesian Language and Literature at Leiden University from 1955 until 1976. Since 1992, the biennial award has been handed alternately to a Dutch and an Indonesian scholar or public figure for their contribution to the development or better understanding of Indonesian culture. I attended the festive ceremony as a second-year student of Professor Henk Maier, Teeuw's successor in Leiden. Mohamad's speech would make an everlasting impression on me. 
It is based on the word semu, which suggests something that 'not is what it is' but at the same time also 'resembles a certain characteristic' (Goenawan Mohamad 1993:117). In short, with pasemon people express themselves playfully and create a world in which meanings are context-dependent, never fixed and endlessly postponed. It is one of the main constituents of the 'fun' of writing and reading literature (Goenawan Mohamad 1993:118).

For Mohamad, pasemon referred not only to a literary device, but also to the general condition of Indonesian literature. He even considered it a symptom of Indonesian society as 'a society that had undergone culture as a trauma' (Goenawan Mohamad 1993:118). His personal experience of 'culture as a trauma' reflected the cultural experiences of many other Indonesians who grew up in post-colonial Indonesia. For instance, for many it was traumatic that the state education system forced them to use a standardized regional or national language different from their local mother tongue. Also traumatic was that their 'own', local culture became excluded from, as well as suppressed and immersed by, a set of regional and national model cultures officially sanctioned as 'cultural peaks' (Goenawan Mohamad 1993:119; Yampolsky 1995:702-4). Some people attempted to overcome their feelings of rootlessness and cultural loss by creatively engaging in Indonesia's national language and literature. Ironically, however, the national language and literature underwent their own traumatic moments (Goenawan Mohamad 1993:118-21). It is in the latter, national cultural context that pasemon developed its double function as index of trauma and force of playfulness and liberation.

According to Mohamad (1993:120), for the first generation of modern Indonesian authors (1920s and 1930s), who called themselves pujangga ('men of letters'), the national Indonesian language and literature were creative means to break away from the old colonial structures and produce a new sense of community. During Sukarno's Old Order and especially Suharto's New Order, the Indonesian language would become the language of education, bureaucracy and mass media, and gradually develop into an official language far removed from the discursive realities of everyday life. Mohamad (1993:121) argues that this official language was devoid of any Bakhtinian 'carnival', as it did not stimulate the senses and severely restricted individual expression, creative interaction, and wordplay.

In the work of artists and also in everyday interaction, pasemon would represent people's awareness of being encapsulated in a cultural system of officialdom, homogeneity and creative poverty, but also their capability to undermine the system and bring back creativity, playfulness and sensuousness. This double-sidedness of pasemon has been manifested in the tendency of Indonesian literary artists from the late 1960s until the late 1980s to create 'meaningless' works. Their works can be seen as a reaction against the slogans 
and speeches of politicians of the 1960s and the impersonal language of the bureaucracy since the 1970s. Within the literary world, it can also be considered a statement against the emphasis on meaning, coherence and totality of the writers of the Angkatan 1945 ('1945 Generation') and the socialist-realism of the left-wing writers of the 1960s (Goenawan Mohamad 1993:124-5).

Examples of 'meaningless' works are Rendra's theatre without dialogues (late 1960s), Putu Wijaya's 'deconstruction' theatre and particularly Sutardji Calzoum Bachri's mantera poetry. ${ }^{4}$ These works can be seen as pasemon, as they signal creative revolt and escape, but also express disappointment with Indonesia's cultural and political climate. Mohamad argues that literary artists were so disappointed with the Indonesian language that they started to create not just 'meaningless' but almost 'wordless' works of art, which only had room for silence and displayed no intimacy or playfulness. This development seemed to mark the end of pasemon as well as Indonesian literature in general. Nevertheless, Mohamad (1993:126-8) concluded his essay with optimism about the future of Indonesian literature, expecting that the pasemon play with words and meanings would find its fullest potential again.

Apart from the 'meaningless' and 'wordless' works of art, there have been many other strategies in Indonesian literature, media and society to undermine official culture and give expression to thoughts and feelings on a grassroots level. Some of these strategies are even closer to Mohamad's concept of pasemon than the examples mentioned in his speech and essay. One outstanding strategy is plesetan, which means 'slip of the tongue'. It also refers to deliberate punning and word games, in which humorous effects are achieved by interchanging words and their meanings on the basis of sound association (Jurriëns 2004:154; Zimmer 1998). It has been popular in youth culture, the mass media and literature especially since the early 1990s.

Ariel Heryanto (1996) distinguishes three types of plesetan. The first type is word play for entertainment, not serving any explicit ideological goals. The second type aims at reversing hierarchies and power relations, for instance by turning around names of official institutions or making a curse sound respectful. It is used as a counter-strategy by or on behalf of the weak, poor or suppressed in society. The third type is plesetan as a radical and serious discipline, which is not merely oriented towards laughter or the reversal of

4 Goenawan Mohamad 1993:125. Contrary to Mohamad, I would describe these works as 'opaque' rather than 'meaningless'. They are opaque, as that they do not provide a transparent window on reality. This does not imply meaninglessness, though, but rather a different way of meaning production. In these works, meaning is not produced through modes of representation, but modes of presentation, relating to the materiality or physical appearance of a work of art. For further explanation of the often overlooked concepts of presentation, opacity and materiality, see Jurriëns 2004:1-3, 15-31. 
social power relations, but questions and undermines any grand narrative with truth claims (Heryanto 1996:102-3). This discipline is similar to poststructuralist traditions that work to 'de-doxify cultural representations and their undeniable political import' (Hutcheon 1989:3). Heryanto considers the Balinese poet Putu Wijaya as its representative par excellence. ${ }^{5}$

The second and third types of plesetan are manifestations of pasemon, as they combine word play with the recognition of and potential for emancipation from cultural trauma. During the New Order, the radio programme 'Dongeng plesetan' ('Tales of punning', Bandung) used these types of plesetan for delivering socio-political criticism and undermining notions of Sundanese cultural essentialism (Jurriëns 2004:147-66). A pasemon-like counter-cultural strategy used by journalists from the written press was to make their readers 'read between the lines' (McDaniel 1994:289). For instance, they would visibly juxtapose contradictory statements of government officials in their articles but refrain from drawing any explicit conclusions, thus conveying political analysis while reducing the risk of censorship or worse. Returning again to Ajidarma, when Indonesian journalism was stifled, it used literary devices such as pasemon to speak. Now, in times of Reformasi, journalism has obtained more opportunities 'to speak for itself', using concepts and styles further removed from the world of literature and closer to the world of journalism proper.

\section{Reformasi; Carnival and dialogism}

A fruitful metaphor for describing the development from 'underground' heteroglossia during the New Order to public reform during Reformasi is Will Derks' 'mycelium' (2004). The mycelium, analogous to Deleuze and Guatarri's idea of the rhizome, is the underground network of the mushroom, which 'produces its fruiting bodies above ground now here, now there, then again elsewhere' (Derks 2004:188). Derks uses the metaphor to describe the mushrooming of regional literary centres in contemporary Indonesia, 'bringing forth many separate centres of literary fruition, depending on certain auspicious circumstances in these particular spots' (Derks 2004:188). Although not all Reformasi-linked activities are necessarily multi-centred, the idea of the mycelium is useful for identifying the presence, development and greater or lesser interconnectivity of creative forces in Indonesian civil society that were denied the sunlight by the New Order officials, and have come to sprout at different places, different moments and in different shapes since the fall of President Suharto. 
Reformasi can also be seen as a process which, by vehemently unleashing the anger and creative energy that had been stored in society for so long, has reversed and undermined social hierarchies in a manner relatively similar to Bakhtin's carnival.

carnival celebrated temporary liberation from the prevailing truth and from the established order; it marked the suspension of all hierarchical rank, privileges, norms, and prohibitions. Carnival was the true feast of time, the feast of becoming, change, and renewal. It was hostile to all that was immortalized and completed. [...] This temporary suspension, both ideal and real, of hierarchical rank created during carnival time a special type of communication impossible in everyday life. This led to the creation of special forms of marketplace speech and gesture, frank and free, permitting no distance between those who came in contact with each other and liberating from norms of etiquette and decency imposed at other times. (Bakhtin 1984b:10.)

There are some profound differences, though, between Reformasi and common celebrations of real-life carnival. Firstly, while these celebrations are temporary, Reformasi has often been described as a 'transition' process (Schulte Nordholt 2002:3-4) that gives no clear indication of when or how its main objectives will be achieved. Secondly, contrary to Bakhtin's carnival ideal, real-life celebrations are often controlled by the official system aiming for nothing but the maintenance or restoration of the old order (Holquist 1984:xviii; Stam 1989:95). The main thinkers and actors behind Reformasi certainly do not wish for the come-back of a New Order-like cultural and political system, but attempt to move Indonesian society into new directions amidst unforeseen and unpredictable circumstances.

A clear illustration of Bakhtinian carnival in Indonesian society is some of the recent developments in written literature. Since the late 1990s, young authors have produced writings with playful and explicit descriptions of the body, sexuality and other social taboos. Many of these authors are female, which makes their emergence on the literary scene itself a carnivalesque event, as it reverses the conventional roles of male author and female reader, and destabilizes the foundations of the literary establishment as well as social hierarchy in general. Commenting on the early Reformasi works of Rieke Diah Pitaloka, Djenar Maesa Ayu and Maftuhah Jakfar, three women of the new generation of writers, the Indonesian feminist scholar Julia Suryakusuma (2004:366) argues that

On one hand, the writings of these women were very individual, reflecting their inner voices: their anger, pain, anguish, desires, hopes, as well as their spiritual yearnings. But at the same time their works were the expression of a collective sentiment and pain, a reflection of the condition, indeed, the turmoil of the times, and an expression of the crie de coeur ['cry from the heart'] of the Indonesian people. (Suryakusuma 2004:366.) 
Djenar Maesa Ayu, for instance, has written short stories that address themes such as incest and paedophilia. According to Suryakusuma (2004:371-6), her specific treatment of sexual taboos - as in her short story 'Saya menyusu ayah' ('I suckled father') - should be seen as an effort to deconstruct patriarchical structures and reverse the roles of men and women in society. Suryakusuma (2004:379) also believes that Ayu's exploration of 'the profane' or 'the dark side of life' should encourage the Reformasi movement to try and expose the dark sides of Indonesia's past and present, as 'only by opening up and lifting the veil of our dark side will we [the Indonesian people] be able to engage in the process of self-healing which has been delayed for too long'.

People have also channelled the energies unleashed after the fall of Suharto through (radio) journalism, which in several of its manifestations is characterized by an attempt at dialogism in response to the monologism of New Order's official culture. This dialogism functions as a type of metajournalism and can be found in journalistic concepts, programme genres and institutional organization forms that are designed to engage and emancipate civil society. Dialogism here does not merely imply dialogue in a literal sense, as in a conversation between two or more people, but also people's 'ideological becoming' in Bakhtinian sense (Bakhtin 1981:342-6).

According to Bakhtin (1981:276-7), dialogue is the condition of every word or 'living utterance'. This means that words or utterances never stand on their own, but are always shaped by their previous, present and forthcoming dialogic interactions with other words, in always different socio-ideological contexts (Bakhtin 1981:279-80). People's ability to play with words and their contexts contributes to their ideological development, as it gives them insight into the idea of the relative, context-bound character of the meaning of words.

Bakhtin identifies two types of discourse, 'authoritative discourse' and 'internally persuasive discourse'. He argues that authoritative discourse hampers people's ideological development by demanding unconditional obedience and not permitting any play with words and their contexts (Bakhtin 1981:343). Similar to authoritative discourse, internally persuasive discourse is also directed at shaping people's 'ideological interrelations with the world' (Bakhtin 1981:342). However, unlike the structure of authoritative discourse, 'the semantic structure of an internally persuasive discourse is not finite, it is open; in each of the new contexts that dialogize it, this discourse is able to reveal ever newer ways to mean' (Bakhtin 1981:346).

In this book, I will analyse dialogic organization forms and discursive practices that are 'persuasive' rather than 'authoritative', as they are neither free from ideological and commercial motivations nor deny any opportunity for further play, negotiation and contestation. They 'reveal ever newer ways to mean' by providing meta-journalistic comments on the role of news radio 
and their audiences in post-Suharto Indonesia. In this way, they contribute to the ideological becoming of media producers and consumers, who are in the process of breaking with the legacy of New Order's official culture, including its authoritative discourse and monologism. In other words, dialogism in this book does not merely relate to radio journalism that is open to civil engagement and participation, but radio journalism that makes people aware of the ideological underpinnings of the media and other forms of discourse and social organization. 



\section{Chapter iiI}

\section{Media and publicness}

This book focuses on concrete manifestations of 'publicness' in radio programmes, genres and institutional forms. However, publicness also has a history as an idea much discussed in Indonesia, especially since the end of the New Order when the space for society to express itself in public expanded dramatically. This chapter will address a part of that history, relating to discussions in society about ways to give shape and manage the newly conquered public space, and specifically the efforts of Indonesian academics and NGO activists to disseminate the notion of public media.

Many of the debates that produced the context for the new ideas and practices in post-Suharto radio journalism have been directly or indirectly inspired by Jürgen Habermas' work. In this chapter, I will compare the 'Indonesian' debates with Habermas' thoughts on the public sphere and identify several heuristic tools that will be used for the analysis of case-studies in the following chapters. One recurring issue in the debates has been the call for independent bodies monitoring the public quality of the Indonesian radio scene. I will discuss the main monitoring body for radio and television broadcasting that came into being during Reformasi, the Komisi Penyiaran Indonesia (KPI, Indonesian Broadcasting Commission). I will also focus on Radio Republik Indonesia's (RRI) attempts to change from a governmentcontrolled institution to a formally public one. At the same time, I will argue that publicness is a value rather than a media category, which - contrary to Habermas' ideas - is not necessarily negatively affected by contemporary forces such as commercialism and media segmentation.

\section{The Depok School and the migration of concepts}

One pioneering group with a specific interest in the relation between radio and the public sphere has been the scholar-activists affiliated to the Communications Department of Universitas Indonesia (UI, University of Indonesia), including Victor Menayang, Effendi Gazali and Dedy Hidayat. These cosmopolitan media experts, who had their education at universities 
in the United States and Europe, call themselves the 'Depok School' (Effendi Gazali 2002a:ix, 2002c:55), which refers to the location of their university in the Jakartan suburb of Depok. More interestingly, the name is also a clear allusion to the Frankfurter Schule, the school of thought of which Habermas is considered to be a late representative. Since 2005, members of the group have been involved in innovative television production, including the popular genre of political parody (Jurriëns 2008).

In 2002, Gazali published an edited volume about radio and the public interest with contributions from the school members and several other media scholars and NGO activists. Depok School's central thought presented in the volume was that a media institution can only be considered 'public' if it accepts supervision and evaluation by the audience.

A Public Broadcasting Institution is a broadcasting institution that has a vision to improve the quality of public life, the quality of a nation's life and also the quality of the relations between nations in general. It also has a mission to become a forum for discussing, articulating and serving the needs of the public. This broadcasting institution significantly acknowledges the supervising and evaluating role of the public in its position as audience and active participant. Therefore, a Public Broadcasting Institution is neither a Government Broadcasting Institution nor a broadcasting institution that is only based on the laws of the market. (Effendi Gazali 2002b:44, see also 2002a:ix and 2002c:55.)

According to the Depok School members, the supervising and evaluating role of the audience should be institutionalized in Institutes for the Supervision of Public Media that reflect the diversity of the public (Effendi Gazali 2002a:ix, 2002c:55). They make a distinction between organizations that are publicly owned and organizations that serve the public interest, arguing that serving the public interest is the duty of any media institution regardless of its funding or institutional organization (Effendi Gazali 2002c:53). They rightly point out that public funding can be an important strategy of anchoring a broadcasting organization in society, but only if it contributes to the organization's accessibility and accountability to the public (Effendi Gazali 2002b:41-4). The examples of Televisi Republik Indonesia (TVRI) and RRI during the New Order confirmed that this is not always the case.

The Depok School defines the public sphere (ranah publik) as a 'public space' (ruang publik) independent from the economic system and the state, where members of the public conduct rational discussions, formulate their opinions and monitor the government (Dedy N. Hidayat 2002:15; see also Effendi Gazali 2002d:85). This notion of the public sphere is based on the ideas of Habermas and his interpreters, particularly Craig Calhoun (1992), which have migrated to Indonesia through the Depok School's research projects and workshops, among others. Since 2001, the Depok School has 
been active in ten Indonesian provinces and cooperated with more than two hundred local NGOs, universities, media organizations and regional parliaments (Effendi Gazali 2002a:ix).

Although the Depok School claims the idea of independent institutions for the supervision of broadcasting activities and the representation of the public interest, similar ideas have been put forward by other Indonesian organizations since early Reformasi. In 2000, the Media Law Department of Internews Indonesia published a book on the role of radio in developments related to otonomi daerah, or regional autonomy. It included an article by Louie Tabing, the Philippine-born vice-president for Asia of the World Association of Community Radio Broadcasters (AMARC), who pleaded for dewan penyiaran ('broadcasting boards') which, similar to Depok School's supervising institutions, had to monitor community broadcasting activities and check whether the people involved gave a fair representation of the diversity of groups in each community (Tabing 2000:133).

Another organization known as Komunitas Televisi Publik Indonesia (KTVPI, Community for Indonesian Public Television) has focused on developing similar strategies for making media institutions transparent and accountable to the public. KTVPI was established as part of the NGO Yayasan Sains, Estetika dan Teknologi (Science, Aesthetics and Technology Foundation) in 1999. It is run by the acclaimed Indonesian film director Garin Nugroho, the media scholar and head of Lembaga Penelitian, Pendidikan dan Penerbitan Yogyakarta (LP3Y, Yogyakarta Institute for Research, Education and Publication), Ashadi Siregar and several other media practitioners, scholars and activists. KTVPI's main task is to contribute ideas that help TVRI transform from a government institution into a public television station (Garin Nugroho 2002:viii; Kitley 2003:111-2). According to Siregar (2000:10), TVRI's transparency and accountability as a public medium should be safeguarded by the establishment of independent institutions that monitor TVRI's broadcast content and financial structure.

An early pioneer in introducing more general concepts of civil society and the public sphere in Indonesia is the scholar Muhammad A.S. Hikam, whose work almost reads as a blueprint for Reformasi. In his 1996 monograph Demokrasi dan civil society ('Democracy and civil society'), Hikam already addressed themes such as the authoritarianism of the New Order regime, the need for democratization, and the key role of civil society in reforming Indonesia's socio-political system. According to Hikam (1996:3, 84, 217), civil society consists of areas of social life that are independent from the state, have a voluntary and self-supporting character, and adhere to the rules of civil law. Hikam's $(1996: 3,85-6,217)$ public sphere is a part of this civil society and provides a space for citizens to communicate with each other in freedom.

Similarly, the US-based scholar Adam Seligman (1992:9) has defined the 
public sphere as 'a sphere of civil society (or civil life) beyond the state and yet transcending purely individual existence'. Seligman's (1992:122) civil society encompasses social identities and activities that are not directly controlled by the state and go beyond the intimate sphere of family life. This type of civil society has both private and public aspects, as it depends on the participation of individuals in collective life. The very privacy of the participating individuals guarantees that collective identity and activity goes beyond the state and is civil indeed.

The public space of interaction in civil society is a public space only insofar as it is distinguished from these social actors who enter it as private individuals. Where there is no private sphere, there is, concomitantly, no public one: both must exist in dialectic unity for sense to be made of either one. (Seligman 1992:5.)

In democracies, the state guarantees the possibility of public life with a personal face - beyond the state as an impersonal locus of authority (Calhoun 1992:8) - by institutionalizing, respecting and stimulating citizenship or 'the values of membership and participation in collective life' (Seligman 1992:101). This type of citizenship is not merely about individuals exercising their private rights, but about individuals sharing a sense of solidarity with each other (Seligman 1992:118).

According to Hikam (1996), during Indonesia's parliamentary democracy of the 1950s, social and political organizations in civil society could grow because of the support of the people and the lack of intervention by the political elite. During the Guided Democracy of the late 1950s and 1960s, however, civil organizations lost their independence and were used by the ruling power for mass mobilization and self-legitimization (Muhammad A.S. Hikam 1996:4). Eventually, during the New Order, the state had strengthened its presence in almost every aspect of public life. The Indonesian middle class had also grown, but depended too much on the state to become a tool for counter-balancing state power as in Western societies (Muhammad A.S. Hikam 1996:5). NGOs, although large in numbers, were equally powerless, as they could not survive without the financial and political support from the government and international sponsors. The press, another potential pillar of civil society, had seen the creation of large business conglomerates, but was curbed by bans, censorship and government-controlled licence procedures (Muhammad A.S. Hikam 1996:6).

Hikam (1996:32) predicted that any attempt at democratic reform in Indonesia would be accompanied by a period of transition in which different parties, including the old ones, would compete to secure a spot in the new social and political establishment. Almost in prediction of the South-East Asian economic crisis of 1997, he argued that the reform process would be strongly influenced by economic, political and social developments on a global level 
(Muhammad A.S. Hikam 1996:33). Basing himself on the democratization process in Eastern Europe almost a decade earlier (Muhammad A.S. Hikam 1996:76-95), he also rightly indicated that the main initiators of reform would be intellectuals - particularly students - the middle class, and joint forces of farmers and labourers (Muhammad A.S. Hikam 1996:58).

Hikam, who would later become the Minister of Research and Technology under President Abdurrahman Wahid (1999-2001), used the English term 'civil society' and based himself on Western sources such as De Tocqueville and Habermas. Other scholars and activists have explained the concept of civil society in Indonesian terms and used non-Western sources including Islamic traditions. In recent years, civil society has been referred to as masyarakat sipil (sipil is the Indonesian spelling of 'civil', masyarakat means 'society'), masyarakat warga/kewargaan ('citizens society') and masyarakat madani ('city's society') (Wolters 2002:139-40; Muhammad A.S. Hikam 1996:3). In the last interpretation, developed by liberal Islamic scholars such as Nurcholis Madjid and Dawam Rahardjo, madani is derived from madina ('city'), an Arabic equivalent of Latin 'civil'. However, for Muslims, madani also bears connotations with Madina, the city where the Prophet Muhammad established the first Islamic state and constitution (Wolters 2002:140; Hefner 2000:189).

\section{Habermas, the bourgeois public sphere and the mass media}

As mentioned earlier, many of the 'Indonesian' public sphere, public media and civil society concepts have their roots in Habermasian thought. Habermas' own work as well as Calhoun's interpretation used by the Depok School identifies discourse or communicative action as a crucial factor in shaping and coordinating the public sphere. Habermas (1989b:231-2) defines the public sphere as an institutionalized and accessible forum that offers citizens the opportunity to conduct rational debate and reach consensus about topics related to the state and other authorities.

By 'public sphere' we mean first of all a domain of our social life in which such a thing as public opinion can be formed. Access to the public sphere is open in principle to all citizens. [...] It is no accident that these concepts of the public sphere and public opinion were not formed until the eighteenth century. [...] It was then that one learned to distinguish between opinion and public opinion, or opinion publique. [...] Public opinion, in terms of its very idea, can be formed only if a public that engages in rational discussion exists. Public discussions that are institutionally protected and that take, with critical intent, the exercise of political authority as their theme have not existed since time immemorial - they developed only in a specific phase of bourgeois society, and only by virtue of a specific constellation of interests could they be incorporated into the order of the bourgeois constitutional state. (Habermas 1989b:231-2.) 
Habermas has traced the roots of contemporary notions of the public sphere to eighteenth century Europe, which saw the rise of the modern state, capitalist economic activity and bourgeois society. Capitalism, one of the foundations of the bourgeois public sphere, completed the privatization of civil society by allowing people individual control of property and production. Two other foundations were the increasing availability of information and education, which enabled the public to go beyond common opinion and develop considered thoughts. People with the appropriate financial and cultural capital had access to the institutions of the public sphere - including meeting places such as coffee houses (England), salons (France) and table societies (Germany) and print media and literary works such as journals of opinion, novels and theatre plays (Calhoun 1992:12-5). According to Habermas (1989a:37; cited in Calhoun 1992:13), the potential of the public sphere to represent civil society as a whole was not necessarily diminished by its specific admission criteria, as 'it always understood and found itself immersed within a more inclusive public of all private people, persons who - insofar as they were propertied and educated - as readers, listeners, and spectators could avail themselves via the market of the objects that were subject to discussion'.

Habermas (1989b:236) regrets that in contemporary Western society the foundations of the public sphere have been undermined by a process of 'refeudalization'. Refeudalization means that state and civil society are no longer distinct, but have become interlocked, with the state penetrating the private realm on the one hand and private organizations assuming public power on the other. As a consequence, the public sphere has come to resemble an arena where legislators stage displays for their constituents, and special interest groups seek to increase the prestige of their own positions (Calhoun 1992:21, 26). The different parties in this arena prefer to negotiate mutually beneficial compromises with each other rather than to organize truly critical discussions to the benefit of society as a whole.

With the interlocking of the public and private domains, not only do political agencies take over certain functions in the sphere of commodity exchange and social labor; societal powers also take over political functions. This leads to a kind of 'refeudalization' of the public sphere. Large-scale organizations strive for political compromises with the state and with one another, behind closed doors if possible; but at the same time they have to secure at least plebiscitarian approval from the mass of the population through the deployment of a staged form of publicity. (Habermas 1989b:235-6.)

Another aspect of refeudalization has been the 'externalization of the inner life' by citizens reducing the private sphere to family affairs and withdrawing from 'their socially controlled roles as property owners into the purely "personal" ones of their noncommittal use of leisure time' (Habermas 
1989:159; cited in Calhoun 1992:22). As a consequence, rational debate has been replaced by 'apolitical sociability' and the passive consumption of popular culture. Habermas here follows the same critique of mass culture in which earlier members of the Frankfurter Schule played a prominent role (Calhoun 1992:22-3).

According to Habermas, the refeudalization of society has been reinforced by the modern audio-visual mass media such as radio, film and television, which have a far greater immediacy than the print media and are capable of creating a 'secondary realm of intimacy' with the audience (Calhoun 1992:24). States and corporations have exploited this immediacy by turning politicians into media stars and instilling motivations in the audience that respond to specific political or commercial interests. At the same time, however, the media give the audience an image of itself as a group of private citizens that contributes responsibly to public opinion rather than a group of media consumers that is being persuaded and manipulated (Calhoun 1992:24-6).

A concrete illustration of Habermas' argument about the use and abuse of the immediacy of the electronic media is Timothy Cook's (1998) analysis of broadcast journalism. Cook (1998:12) argues that, particularly in the United States, broadcast journalists and politicians are involved in 'a constant but implicit series of negotiations over who controls the agenda, what can be asked, where and how, and what a suitable answer will be'. This 'negotiation of newsworthiness' contaminates journalism's function as the 'Fourth Estate' or 'Fourth Branch of State' (Schultz 1998), which is meant to secure the autonomy of the public sphere - of which the press is a part itself - and serve the 'exercise of citizenship' (Hjarvard 1998:211). The Fourth Estate depends on journalists remaining independent from and critically examining the other three branches of state: those of executive, legislative and judicial power, respectively. In reality, however, the standards of professional journalism are often weakened by government officials using border-crossing strategies to have direct access to the media, turn journalists into accomplices and use the press in their own interest.

\footnotetext{
Linking media strategies and governing strategies has become an attractive option for officials, whether to communicate to an ever more complex and dispersed political system, to influence the context in which other officials decide inside and outside their own institutions, or to make policy itself by the use of performative language. Officials have furthered the importance of news making by hiring professional public information officers who bring the journalistic perspective into the governmental process. (Cook 1998:16.)
}

The fruitfulness of Habermas' theory of the bourgeois public sphere is that it provides a heuristic tool for the disclosure and analysis of these and other problems that are at the heart of twentieth and twenty-first century capital- 
ist society. In spite, or perhaps because, of its impact and productivity, the theory has also provoked much controversy and criticism. A point of criticism I share with others (for instance, Calhoun 1992:33) is that the modern media are not necessarily as uniform and anti-democratic as Habermas suggests. Alternative, democratic media strategies certainly exist, as some of the examples from the contemporary Indonesian radio landscape in this book will demonstrate.

\section{Radio Republik Indonesia; Public radio and the Broadcasting Law}

Not surprisingly, media scholars, practitioners and activists evaluating the publicness of Indonesian radio have had a special interest in RRI. Some of their research findings and recommendations have been translated into legal documents officially sanctioning RRI's status as public broadcasting institution. The most influential of these legal documents, the 2002 Broadcasting Law states in article 14 that RRI 'has an independent, neutral, non-commercial character and functions to provide services in the people's interest'. The 2005 Government Regulations Numbers 11 and 12 confirm RRI's new status in more detailed and operational terms.

Until 2000, RRI held the status of government broadcasting institution under the Department of Information (Departemen Penerangan), which meant that it was owned, ruled and financed by the government. In the transition period from 2000 to 2005, it was a state-owned corporation (BUMN, badan usaha milik negara) under the Department of Finance (Departemen Keuangan), which meant that it had to search for its own funding but not strive to make profits. As a public broadcasting institution, RRI now consists of a supervisory board (dewan pengawas) and a board of directors (dewan direksi). The supervisory board includes five delegates from the public, the government and RRI and has the duty to elect and monitor the board of directors. The board of directors also consists of five members and is involved in policy-making and broadcast coordination. ${ }^{1}$ The Broadcasting Law, specifically article 15, mentions that RRI is allowed and expected to receive its income from a diversity of sources, including listener fees, the national budget, advertisements and voluntary contributions.

In 2006, RRI owned 52 national and regional stations as well as one international service for Indonesian-language listeners overseas, called Voice of Indonesia. RRI's broadcasting priorities are news, education, culture and

1 'Tentang kami'. http://www.rri-online.com/modules.php?name=TentangRRI (accessed 13-7-2006). 
music. The national head station in Jakarta has six different programma, or channels (abbreviated to Pro I, II, III, IV, V and VI, respectively) on six different frequencies. Pro I focuses on adult listeners in the Jakarta region, Pro II on Jakartan youth, Pro III on news and information, Pro IV on culture, Pro V on education and Pro VI on classical music and foreign languages. The majority of regional RRI stations have three different channels (abbreviated to Pro I, II and III, respectively), each with its own frequency. Pro I targets rural communities, Pro II urban audiences, while Pro III positions itself as a news and information channel. ${ }^{2}$

When I interviewed employees of the regional RRI stations in Bandung, Denpasar and Padang in 2001 and 2002, when RRI was still a BUMN or perusahaan jawatan (state 'service enterprise'), there was much uncertainty about whether RRI's future direction would be governmental, commercial or public. One of the fundamental changes underwent by RRI was that it could rely less on government funding and had to start searching for alternative sources of income. RRI Padang, for instance, established its own Marketing and Company Development (Pemasaran dan Pengembangan Usaha) department, which attempted to earn money from selling air time to advertisers, attracting sponsors for talk shows and renting out broadcasting equipment to private radio stations and media training institutes. ${ }^{3}$

At the same time, the Padang staff hoped that their station would not become entirely commercial, as this would automatically lead to the redundancy and forced dismissal of staff. One of the strategies to make RRI Padang more attractive for (potential) advertisers and sponsors, and simultaneously give it a more public image, was to start the production and broadcasting of infotainment and interactive talk shows on current affairs, including 'Padang bicara' ('Padang talks') and 'Dinamika seputar kota' ('The dynamics around the city'). They also tried to introduce a more informal, colloquial broadcast language and break with the monological, stiff and distanced presentation style practiced during the New Order. ${ }^{4}$

The Padang staff was dissatisfied that RRI, in spite of the Reformasi agenda of decentralization and regional autonomy, continued to adhere to a hierarchical, centre-oriented structure of one head office (cabang utama, or 'main branch') in Jakarta and numerous branch offices in the regions, which in order of size or importance were called cabang madya ('middle branches'), cabang muda ('young branches', including RRI Padang) and cabang pratama ('sub-branches'). They also complained that the regional stations still had to

2 'Sejarah'. http://www.rri-online.com/modules.php?name=Tentang RRI\&op=sejarah (accessed 13-7-2006).

3 Idham Hamid, personal communication, Padang, 20-8-2002.

4 Mustawar Lubis, personal communication, Padang, 20-8-2002. 
share their income with the head office. ${ }^{5}$

The key element of RRI's new, post-BUMN status of public organization is the supervisory board, which elects and monitors the board of directors. This is the kind of supervisory body for public radio that the Depok School and other media scholars and activists had pleaded for. ${ }^{6}$ Article 14 of the 2002 Broadcasting Law included a general description of dewan pengawas, while Government Regulation No. 12 of 2005 contained specific details about the board's modus operandi. According to the Government Regulation, the government seeks feedback from the public in nominating candidates for the supervisory board to the Indonesian parliament (Dewan Perwakilan Rakyat, DPR). The members of parliament eventually decide on the five board members, who are elected for a period of five years and can only be re-elected once (Peraturan Pemerintah 2005b, Articles 8 and 19).

Government Regulation No. 12 as well as two other related 2005 Government Regulations - the No. 11 on public broadcasting in general and the No. 13 specifically on TVRI - have not been without controversy. For instance, KPI has criticized the Government Regulations for giving the Minister of Communications and Informatics (Menteri Komunikasi dan Informatika) the right to issue licenses to public media organizations. According to KPI, this authorizes the government to intervene in public broadcasting and reinstates RRI and TVRI as state rather than public media organizations, whereas the right to issue licences should lie with KPI in its capacity as independent institution. ${ }^{7}$

The conflict about the issuing of broadcasting licences was caused by the unclear, multi-interpretable word negara ('state') in article 33 of the Broadcasting Law, which says that 'the state gives licences and organizes broadcasting'. According to KPI, 'state' here refers to KPI and not the Minister of Communications and Informatics. Later in 2005, the same interpretation problems about the same word arose with four other government regulations on broadcasting - the Numbers 49, 50, 51 and 52 on foreign, private, community and subscription channels, respectively. ${ }^{8}$ This prompted KPI to request the Indonesian Supreme Court (Mahkamah Agung) for a judicial review of all seven government regulations. ${ }^{9}$ So far, the first three regulations have been

5 Mustawar Lubis, personal communication, Padang, 20-8-2002.

6 'Diingatkan, pentingnya dewan pengawas RRI'.

http://www.kompas.co/kompas-cetak/ 0505/16/Politikhukum/1753698.htm (accessed 16-5-2005).

7 'KPI tolak tiga PP Penyiaran baru'.

http://www.hukumonline.com/detail.asp?id=12601 \&cl=berita (accessed 8-4-2005).

8 'Kronologi kontroversi Peraturan Pemerintah tentang Penyiaran'.

http://www.kpi.go.id/index.php?categoryid=52\&p2_articleid=98 (accessed 17-7-2006).

9 'Peraturan Pemerintah'.

http://www.kpi.go.id/index.php?categoryid=23 (accessed 17-7-2006). 
in force in their original formulations, while the application of the last four regulations has been postponed several times.

\section{Komisi Penyiaran Indonesia; Monitoring the publicness of broadcasting}

While RRI and TVRI have their own supervisory boards to monitor their publicness, KPI has the task to monitor the publicness of the Indonesian media landscape as a whole. According to a statement on the KPI website, KPI was a product of the 2002 Broadcasting Law, which stated that broadcasting was a public affair that needed to be regulated by an independent body. ${ }^{10}$ This was a radical change from Indonesia's first broadcasting law of 1997, which stated that the government was in charge of regulation. KPI believes regulation is necessary, as the accessibility of the broadcasting spectrum is restricted due to physical limitations on the availability of frequencies. The commission's two basic principles that make broadcasting organizations serve the interests of the public are 'diversity of content' and 'diversity of ownership'.

The democratization process in Indonesia positions the public as the main owner and controller of the broadcasting domain. Because frequencies are public property and have a limited character, their use should serve the public interest as much as possible. Serving the public interest as much as possible means that broadcasting media have to function as healthy public information providers. Information can be found in various forms, from news to entertainment, science etc. The basis of healthy information provision is 'Diversity of Content' and 'Diversity of Ownership' as mentioned in Broadcasting Law No. 32 of 2002. These two principles are the foundations of every policy formulated by KPI. ${ }^{11}$

In order to guarantee diversity of content and diversity of ownership, KPI admonishes broadcasting organizations to abide by Broadcasting Law Article 18, which strictly forbids media monopolies; and article 31, which stipulates that radio and television stations aiming to expand their transmission area need to have a local branch or cooperate with a local media organization in every region within their scope. KPI uses these and related articles from the Broadcasting Law not only as tools to fight the centralization and monopolization of news and information, but also to give concrete meaning to the idea of regional autonomy and stimulate regional economic and socio-cultural development. ${ }^{12}$

Neither KPI nor the 2002 Broadcasting Law have been without their crit-

10 'Dasar pembentukan'. http://www.kpi.go.id/index.php?categoryid=11 (accessed 17-7-2006).

11 'Dasar pembentukan'. http://www.kpi.go.id/index.php?categoryid=11 (accessed 17-7-2006).

12 'Dasar pembentukan', http://www.kpi.go.id/index.php?categoryid=11 (accessed 17-7-2006). 
ics. One of the most prominent among these critics is LP3Y and KTVPI's Ashadi Siregar, who argues that KPI and the Broadcasting Law restrict the freedom of media organizations by controlling and interfering in their broadcast content. Siregar would prefer the Broadcasting Law only to function as a complement to the Undang-Undang Telekomunikasi ('Telecommunications Law'), which is about issues related to frequency use and transmission technology. The Broadcasting Law could specifically deal with the technological complexities and business implications of these issues, while an independent monitoring body such as KPI could function as a weapon against government officials seeking personal political or financial benefit from the telecommunications business. ${ }^{13}$

According to Siregar, citizens who feel offended by certain broadcast content do not need a broadcasting law or KPI to handle their case, as existing, more general legal means could deal with misconduct by the media as not fundamentally different from misconduct by ordinary citizens. He argues that KPI in its current form, similar to Dewan Pers ('Press Council') during the New Order, seems to function as an extension of the government in curbing the media. He also disagrees with the Broadcasting Law stating that KPI and its regional offices are to be controlled by (diawasi oleh) the national and regional parliaments, and believes a better, less authoritarian formulation would be that the KPI offices have to be accountable to (bertanggung jawab kepada) the parliaments. He also believes that Indonesia is less in need of a broadcasting law or broadcasting commission than an imperative for the government and the media industry to meet society's right on information, for instance in the form of an information act on the freedom and accessibility of information. ${ }^{14}$

Siregar's argument that media producers and consumers are being curbed by KPI and the Broadcasting Law, and KPI's own fear of the growing influence of the Department of Communications and Informatics, illustrates that the concept of publicness is highly contested among Indonesian politicians, media practitioners, activists and scholars. By law and in practice, KPI deals with issues related to broadcast content itself. However, although the spectre of New Order's infamous Departemen Penerangan ('Department of Information') is still haunting KPI, the commission - which, interestingly, during its first term (2004-2007) was headed by the Depok School's Victor Menayang - takes every opportunity to show that it dedicates itself painstakingly to the task of representing the public and improving the quality of

13 'UU Penyiaran; Menghidupkan kembali otoritarianisme'.

http://www.suarapembaruan.com/News/2003/02/17/Editor/edi03.htm (accessed 17-2-2003).

14 'UU Penyiaran; Menghidupkan kembali otoritarianisme'.

http://www.suarapembaruan.com/News/2003/02/17/Editor/edi03.htm (accessed 17-2-2003). 
Indonesian broadcasting. One of KPI's services is its website which contains forms for the public to lodge complaints about media institutions or media content. On the basis of their comments, KPI issues warnings to television stations for screening materials considered harmful - such as representations of sex, violence or superstitious beliefs - or for not being objective in their news reporting. ${ }^{15}$ Documents with these warnings are accessible to the general public on the KPI website.

An example of a KPI warning was a letter sent to thirteen television stations on 22 March 2006. In the letter, KPI reminded the stations that they were using 'broadcast frequencies that were owned by the public and therefore had to be used in the interest of the public and with respect for the social order of values and norms'. ${ }^{16}$ The attachment to the letter contained a detailed list of complaints about specific programmes. The complaints were about obscenity and disrespect for religious values in soap operas and films (for instance, Indosiar's screening of the US movie 'American pie'); vulgar lyrics and dance movements in music programmes (for instance, TVRI's 'Channel dangdut' ['The dangdut channel']); superstition and mysticism in reality shows (for instance, SCTV's 'Di sini ada setan' ['Here is a bad spirit']) and violence in fiction (for instance, martial arts in Global TV's 'Film Mandarin' ['Mandarin films']) and news or investigative programmes (for instance, TPI's 'Sidik kasus' ['Case investigation']). KPI emphasized that it was acting on behalf of the people (masyarakat) and considered taking legal action against stations that refused to stop broadcasting offensive materials and improve the quality of their programmes as part of its responsibility.

KPI has received many complaints from the people that television stations have recently become increasingly daring in showing vulgar, sexually-oriented materials in comedy programmes, sinetron [Indonesian soap opera], music performances, music video-clips, talk shows, variety shows, films and features and documentaries. Similarly, there have also been many complaints about violent content in sinetron, news, films and features. The presence of these programmes demonstrates that national private television stations have excessively violated Broadcasting Law No. 32 and the Guidelines for Broadcasting Conduct/Broadcast Programme Standards (P3-SPS), which have been declared valid from August 2004. Therefore $\mathrm{KPI}$, as part of its responsibility to act in accordance with the people's mandate and uphold the law, is left with no other choice than to follow the road of justice and proceed with actions against violations of the Broadcasting Law. ${ }^{17}$

In other letters, KPI admonished television stations for broadcasting graphic images of casualties, as in reports on a Mandala aircraft crash, September 
2005, and social unrest in Papua, March 2006. The commission also issued warnings against stations breaching the rules of objectivity in current affairs programmes. TVRI, for instance, was warned for its 12 July 2006 edition of the talk show 'Mimbar demokrasi' ('Pulpit of democracy'), which was hosted by Anas Urbaningrum, head of the Politics and Regional Autonomy division of Partai Demokrat (PD, Democratic Party). Especially since PD is also President Yudhoyono's party, KPI argued that 'Mr Anas Urbaningrum's presence as a presenter in this programme created the impression that TVRI was becoming a tool for government interests [again] ${ }^{18}$ Other warnings concerned the use of hidden cameras in humorous reality shows, violence and nudity in live broadcast, and misleading information about SMS tariffs and prize-winner notifications in phone-in quizzes. ${ }^{19}$

KPI's website shows letters from television stations in response to the warnings, in which they usually promise to increase their programme standards. The website's folder on radio programmes and institutions is still empty, perhaps because the absence of visual material makes radio less likely to be offensive, or because the high density and diversity of radio programmes simply makes it a medium too hard to monitor. KPI's ultimate penalty for a media organization continuously harming the public interest is to withdraw its broadcasting licence.

\section{'More than just music'; News radio and segmentation}

As acknowledged by institutions such as the Depok School and KPI, the publicness of media organizations is a matter of the values they represent rather than their official status. The fact that media organizations may represent commercial interests or entertain links with the national government or international media organizations and NGOs does not necessarily reduce their publicness, but calls for a Habermasian evaluation of how these institutions confirm or cross the borders between the public and the private, the local and the global and civil society and the state, and to what extent they resist or contribute to the 'refeudalization of society' and the 'externalization of inner life'.

My case-studies will focus on activities developed by Indonesian radio institutions that can be roughly divided into the following three categories: 1. Activities that represent the ideals of the Habermasian public sphere,

18 'Dasar pembentukan'. http://www.kpi.go.id/index.php?categoryid=11 (letter to the head of TVRI, 21 April 2005; accessed 17-7-2006).

19 'Dasar pembentukan'. http://www.kpi.go.id/index.php?categoryid=11 (letter to the head of TVRI, 21-4-2005; accessed 17-7-2006). 
2. Activities that include alternative strategies for representing the public interest, and 3. Activities that are controversial with regard to the public values they are supposed to defend. The first category includes the institutional structures and programmes of the radio news agencies Kantor Berita Radio $68 \mathrm{H}$ and Internews Indonesia (Chapter IV), the second category community radio (Chapter VIII) and the talk shows and off-air activities of commercial stations (Chapters V, VI and VII), and the third category the programmes and concepts of Radio Mora, a commercial station with a mixed format of news, information about legal issues and entertainment (Chapter VI). This is a rough division made for the sake of the argument, as there is also much overlap between the three categories.

The main factor on the macro level of media management that determines the organizational structures, journalistic concepts, programme contents, broadcast styles, broadcast languages, advertising strategies and off-air activities of the majority of radio stations that will be discussed is the commercial strategy of segmentation. Segmentation means that radio managers give their stations a particular identity by imagining and thus partly creating a target audience or segment of the Indonesian listeners' market. Their decisions on how to create and represent a specific community of listeners are reflected, in a very concise manner, in the genre of the jingle.

Jingles are short sung or narrated commercials, usually accompanied by music, broadcast for self-promotion and containing general information about a station or details about a specific programme or off-air activity. Jingles constitute one of the immediate reference points for listeners to make sense of the discursive flow they are confronted with when tuning in to the radio. The Jakarta news station Trijaya, for instance, identifies itself as 'the real radio' providing 'more than just music' (in English) in jingles that are broadcast several times an hour. These signature tunes are illustrative of commercial stations in the post-Suharto radio landscape trying to get rid of the image of only providing entertainment to the audience. What is 'real' about Trijaya is that its broadcast content includes not 'just music', but also news and current affairs.

Trijaya is part of a national network of radio stations that also consists of SCFM (Surabaya), Prapanca (Medan), Trijaya Yogyakarta (Yogyakarta), Trijaya Semarang (Semarang), Mercurius Top (Makassar) and Voice of Papua (Jayapura). This network is part of the Bimantara business group (see Chapter VI). The programmes of Trijaya Jakarta are also broadcast via World Space, a radio satellite service that can be received anywhere in Indonesia, major parts of Asia and the north of Australia. The network aims at a middle- or high-income audience of urban business people. ${ }^{20}$ One of the ways in which 
it addresses and partly creates this type of audience is by means of the broadcast content and jingles for the programme 'Thank God it's Friday'. This programme is produced in Jakarta and broadcast by the majority of the network stations. The following jingle produced by SCFM, the member station in Surabaya, shows that which is supposedly of interest to the listeners of 'Thank God it's Friday' and the network's audience in general. The jingle was directed at potential advertisers.

Do you want young professionals to know and try your company's new products? You also have to communicate your company's professional services so that they reach their target. Everything is discussed interactively in 'Thank God it's Friday'. Every Friday from 7 until 9 a.m. on SCFM. Apart from the analysis of new products, 'Thank God it's Friday' also includes: lifestyle talk, weekend destination and celebrity profile. Make sure 'Thank God it's Friday' accompanies you on your Friday morning exclusively on 104.7 SCFM. ${ }^{21}$

The jingle confirms that the Trijaya audience is believed to consist of a group of business people, including the radio station's potential advertisers, who are in their early professional career (profesional muda). The special themes of 'Thank God it's Friday' (lifestyle talk, weekend destination and celebrity profile) also imply that the listeners would feel the urge to create their own 'lifestyle' inspired by Western capitalist notions of luxury, have the time and money to participate in recreational activities during the weekend, and find the lives of celebrities intriguing or even a source of inspiration.

Another example of segmentation is Suara Padang ('The Voice of Padang') in Padang, West Sumatra, which is also a news station, but with a profile very different from Trijaya's. Suara Padang's slogan is 'Berita dan dakwah', indicating that the radio station's two main foci are news (berita) and Islamic proselytizing (dakwah). Suara Padang relays national and international news from the Indonesian radio news agency Kantor Berita Radio 68H and the Voice of America, while it gathers news about Padang and West Sumatra from its own reporters and local newspapers. ${ }^{22}$ Two of its Islamic programmes are the interactive talk show 'Masail islamiyah' ('Islamic problems'), in which listeners can ask questions about religious issues to experts in the studio, and 'Mutiara hikmah' ('Pearls of religious wisdom'), which consists of jingles

21 Anda ingin profesional muda tahu dan mencoba produk baru perusahaan Anda? Layanan profesional perusahaan Anda juga harus dikomunikasikan agar tepat sasaran. Semuanya dibahas secara interaktif di 'Thank God it's Friday'. Setiap Jumat pagi jam 7 hingga 9 di SCFM. Selain ulasan produk baru di 'Thank God it's Friday' juga ada: bincang lifestyle, weekend destination dan profil selebritis. Pastikan 'Thank God it's Friday' hadir menemani Jumat pagi Anda hanya di 104.7 SCFM (Jurriëns, transcription of a 27-7-2002 broadcast).

22 Yusirwan Yusuf, head of Suara Padang, personal communication, Padang, 19-8-2002. 
with interpretations of Koran verses and is broadcast at least once an hour. At Suara Padang, news and religion remain relatively separate domains, though, as there are no broadcasts in which a specifically Islamic view on topical issues is expressed.

Suara Padang creates and promotes its profile by means of its signature song, which follows the verse structure of pantun, ${ }^{23}$ a Malay literary genre that is very popular in West Sumatra.

\author{
Radio Suara Padang FM \\ Appears sweet and enchanting \\ Radio Suara Padang FM \\ Is here as your friend

\section{Radio Suara Padang FM \\ Full of information \\ And proselytizing that alludes \\ To the blessing of an eternal life}

Padang FM is here together with you

To entertain you all

Padang FM is here together with you

To accompany you in happiness and sorrow ${ }^{24}$

The radio station's management acknowledges that the main reason to combine news and religion is commercial and pragmatic rather than purely religious. It is a strategy to distinguish the station from its competitors and safeguard the crew against verbal or physical attacks from angry mobs that question their religious or patriotic integrity. The crew knows from experience that relaying news from a rich variety of sources, including Western news providers sometimes considered anti-Islamic or anti-Indonesian, involves inevitable risks. Especially when Suara Padang relayed Voice of America broadcasts during the war in Afghanistan in 2001, they received many verbal and physical threats from discontented listeners. ${ }^{25}$

The segmentation of the Indonesian radio landscape as illustrated by Trijaya and Suara Padang can be seen as a typical manifestation of the mar-

23 For a concise description of pantun, see Teeuw 1994.

24 Radio Suara Padang FM / Tampil manis mempesona / Radio Suara Padang FM / Hadir sebagai teman Anda // Radio Suara Padang FM / Sarat dengan informasi / Serta dakwah mengiasi / Berkah hidup yang abadi // Padang FM hadir bersama / Untuk hibur Anda semua / Padang FM hadir bersama / Temani Anda suka dan duka.

25 Yusirwan Yusuf, personal communication, Padang, 19-8-2002. 
keting and consumer orientation of contemporary mass culture. According to Habermas, such segmentation reflects fragmentation rather than diversification, and contributes to the disintegration of the bourgeois public sphere. It would undermine the formation of a mass-based solidarity by failing to facilitate critical discussion to the benefit of all (Livingstone and Lunt 1994:27; Calhoun 1992:25). It would also be symptomatic of the segmentation of society at large, where the sounding board of an educated stratum tutored in the public use of reason has been shattered' and 'the public is split apart into minorities of specialists who put their reason to use non-publicly and the great mass of consumers whose receptiveness is public but uncritical' (Habermas 1989a:175; cited in Calhoun 1992:26).

Seligman (1992:128) explains that this altered relationship between cultural producers and consumers is a negative and paradoxical consequence of the very success of the public sphere, in particular the wide-spread implementation and dissemination of the idea of the use of reason: 'By bringing ever increasing realms of life into the realm of Reason, it also denuded them of any value (especially ethical value) beyond that instrumental calculus of means-end relationship.' Following Max Weber, it is this 'disenchantment of the world' that has left us with 'specialists without spirit, sensualists without heart' (Seligman 1992:128).

However, there are both theoretical and empirical grounds for arguing that the segmentation of society and the media is not necessarily negative and disruptive, but can also bring positive contributions to public life. Some of my case-studies of Indonesian private radio will demonstrate that certain manifestations of mass culture, similar to Habermas' bourgeois public sphere, contain rational-critical debate and address society as a whole. ${ }^{26}$ Other case-studies will show that Habermas' concept itself is in need of a critical re-examination. In this book such a re-examination, more or less in line with Seligman's critique of the idea of reason, will lead to the argument that says, perhaps paradoxically, that rational-critical debate or the capability to address society as a whole are not necessarily required for media such as Indonesian private radio to facilitate and improve public life.

26 I am aware that the 'externalization of inner life' as manifested in the pleasure of producing, receiving or interacting with media content can, in certain cases, serve important social goals or subvert or redefine existing political and social structures too. However, this is not the direction in which I want to lead this book, see also my discussion of 'phatic performance' in Chapter V. 
What is new about the news?

It should be emphasized that Indonesian radio journalism since the late New Order, while being influenced by Habermasian and other imported intellectual thought, is certainly not about journalists, programme producers and audiences neatly applying internationally accepted journalistic concepts to the local context. It is rather about the dynamic struggle of these actors to come to terms with the renewed freedom of expression in their country. Perhaps not surprisingly, audience participation programmes have become dominant as both a symbol of and space for this struggle. With specific regard to such programmes, it does not make much sense to try and give a precise definition of Indonesia's new radio journalism, or judge whether it is good or bad, or 'real' or 'fake', journalism. More useful, as a start, is to try and explain the broader socio-political context that gave this journalism the shape it has.

In her work on the relationship between politics and the written press during the New Order and Reformasi periods, Angela Romano (2003:132) quotes sociologist Gaye Tuchman's definition that 'news imparts to events their public character as it transforms mere happenings into publicly discussable events'. While this is a useful working definition, Romano (2003:40-6, 132, 2005:9) rightly observes that censorship and self-censorship during the New Order prevented many potentially newsworthy issues from entering the public domain by classifying them as politically sensitive, or not in line with the regime's interpretation of a 'free but responsible' press. Since the late 1990s, journalists and media organizations have tried to free themselves from the legacy of these (self-)restrictions by adopting a new paradigm much closer to the ideal of journalism as a watchdog of politics and society (Romano 2003:657). According to Romano (2003:66), two tasks have become priorities for the Indonesian press: firstly, to establish mechanisms for protecting and promoting press freedom; secondly, to increase the professional and ethical standards of the press. As a result, there has been a boom in the creation and revision of government legislation, scholarly literature and practical training courses on print and broadcast journalism (Romano 2003:66).

Masduki (2001:xiii) - Indonesian academic, radio journalist and former head of the Yogyakarta branch of Aliansi Jurnalis Independen (AJI, Alliance of Independent Journalists) - appropriately describes the early post-Suharto period as a 'try and error' (sic) phase of Indonesian journalism, particularly radio journalism. He explains how radio during the New Order positioned itself predominantly as a medium of entertainment (hiburan), not journalism. He regards this tendency as a symptom of the self-censorship of the Indonesian media, who were forced to restrain themselves from any reporting that went against the interests of the government. As a result, the media 'became more and more alienated from the people's real needs', while the 


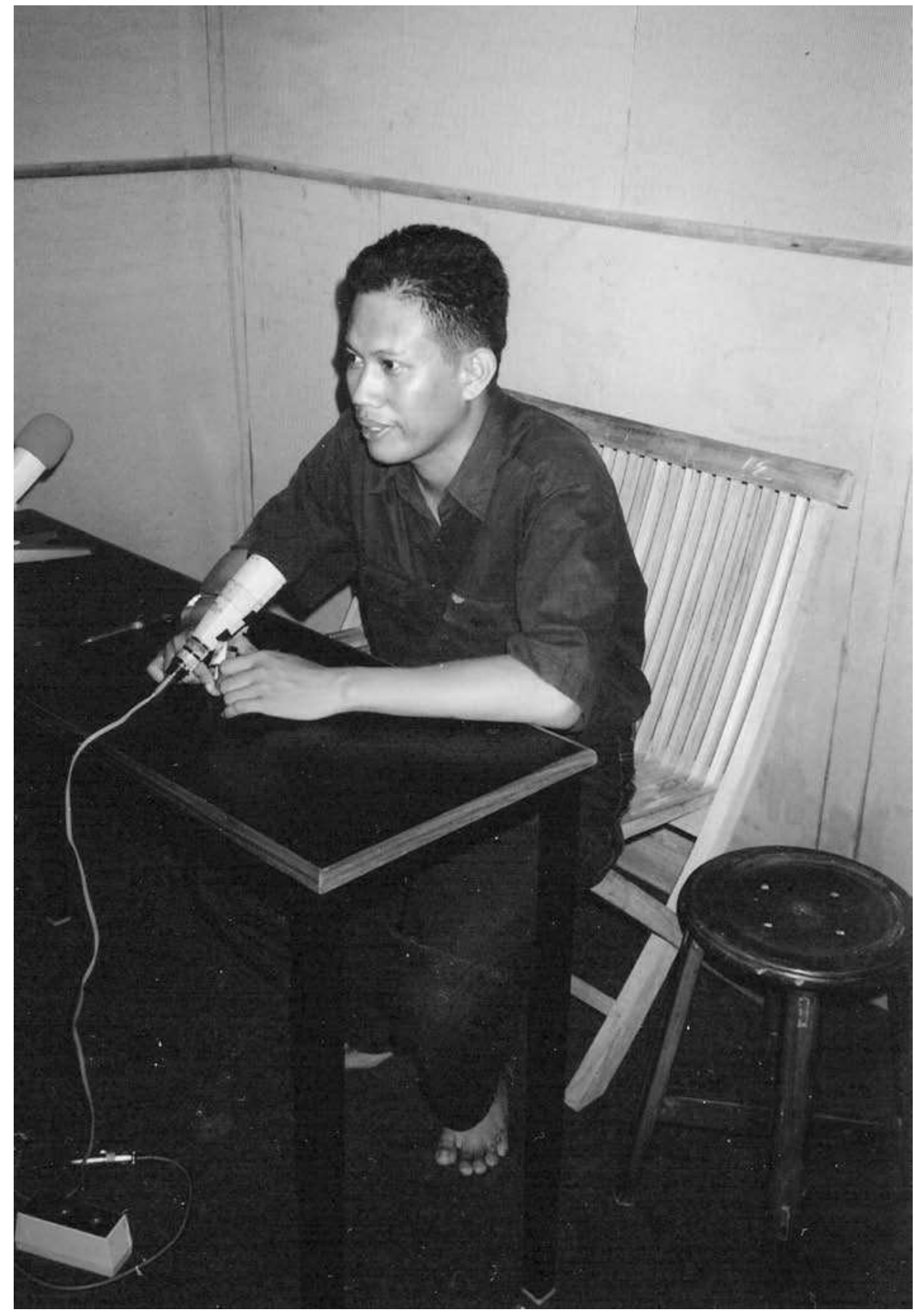

The Indonesian media scholar and radio journalist Masduki, 2001 
people 'became isolated, unaware of their critical function and the fundamental rights they should have received from the government in power' (Masduki 2001:1).

According to Masduki (2003:141), the period between 1998 and 2001 saw some of the most important developments in the history of Indonesian broadcast journalism. Five of the main developments were: 1 . The broadcasting media giving priority to market interests rather than government interests, 2. The introduction of a different ownership paradigm, with community, public and profit-oriented media replacing private, state and non-profit media, 3 . The creation of journalistic content as an alternative to entertainment, 4 . The promotion of the interactive dialogue format in response to the tradition of reactive monologue known from the state broadcasters during the New Order period, and 5. The introduction of digital broadcasting via satellite and the Internet as a technological alternative to analogue broadcasting. Masduki (2003:180) argues that the main challenge for Indonesian radio journalism is 'to secure that the public space that has opened up remains public property'.

Masduki's (2001:3) ideal of Indonesian radio - much in line with Habermas' ideal of the bourgeois public sphere - is that it does not merely distribute information, but also facilitates listeners to have debates, reach consensus, influence government policies and create a sense of community. In Indonesian radio's transitional period of trial and error, many other media practitioners, scholars and NGO activists also attempt to have the listeners and their interests back at the centre of attention of the radio producers and their programmes. This explains why audience participation has become such a popular, although not always effective, concept and practice in the early development of nongovernmental radio journalism. In his book tellingly titled Socrates di radio ('Socrates on the radio') - referring to the strategy of the Greek philosopher to ask people simple but provocative questions, thus stimulating them to talk, reason and discover the truth about things 'themselves' - Suara Surabaya's programme manager, Errol Jonathans, confirms the centrality of the listener, as a representative of the Indonesian public, to the process of Reformasi in general and Indonesian broadcast journalism in particular.

If Reformasi is considered as the spiritual essence of the change of the Indonesian people, radio has to accept wholeheartedly the laws of the 'listener's platform' as a service prerequisite as well as an easy chance to secure its existence in broadcasting, both idealistically and commercially. Thus the information service via interactive opinion or talk shows - in addition to news packages - turns out to constitute a part of Reformasi. (Errol Jonathans 2006:100.)

Suara Surabaya and other radio stations have attempted to reach out to the listener's life world by developing their own versions of interactive radio 
journalism (see Chapter VI) and creating news bulletins that include live interviews and so-called sisipan, or 'inserts' with sounds representing the ambience of an event (Masduki 2003:145; see also Chapter IV). Romano (2003:117-8, 134) explains that such concern with the recipient of media content was rare in New Order print journalism. She argues that President Suharto and other political figures engaged with the media 'in a fashion that prevented direct accountability through public interrogation of his [the president's] actions or policies', while business leaders were also often reluctant to share information with journalists. Only NGOs, academics, religious leaders and certain retired generals were relatively easy to approach and obtain information from (Romano 2003:138). The 'little people' were almost never accessed as a source of information or opinion (Romano 2003:141).

According to Jonathans (2000:52-3), the positive aspect of having listeners as news sources is that it gives them the opportunity to express their 'loyalty' to radio and develop a sense of 'owning' the medium. This sense of ownership can be strengthened by interactive radio journalism as well as other news genres that people can easily understand and identify with, such as infotainment (Jonathans 2006:102; Masduki 2003:2-3) and Suara Padang's mixed format of news and religion. At the same time, interactive radio journalism does not necessarily turn listeners into critical thinkers, and brings with it the risk of listeners creating news that is biased, unstructured or superficial (Masduki 2004:28, 32).

According to Masduki (2004:18-28), journalistic development is also hampered by more general social, political and economic aspects of the Reformasi period. For instance, by companies attempting to create monopolies in the media market, politicians issuing legislation that restricts press freedom, individuals and groups in society exercising physical violence against journalists, and journalists and other media practitioners adhering to low professional and moral standards. This explains the strong efforts of media practitioners, scholars and activists to defend the freedom of the press and increase the standards of the journalism profession (Romano 2003:66).

In his book Kebebasan pers dan kode etik jurnalistik ('Press freedom and the journalistic code of ethics', 2004), Masduki explains that two positive results of these efforts have been the 1999 Press Law and the Kode Etik Wartawan Indonesia (KEWI, Indonesian Journalists Code of Ethics) (see also Romano 2003:66-7). The Code of Ethics was signed in Bandung, 1999, by 26 professional organizations including AJI, Persatuan Wartawan Indonesia (PWI, Association of Indonesian Journalists) and Himpunan Praktisi Penyiaran Indonesia (HPPI, Association of Indonesian Broadcasting Practitioners). The first statement of their declaration was that 'Indonesian journalists respect the people's right to obtain correct information' (Masduki 2003:54). This confirms the centrality of the concept of 'the people' (masyarakat) in the attempts to 
reform the Indonesian print and broadcasting press. Important articles in the first paragraph of the Press Law are Article 11 on the people's 'right of reply' (hak jawab) and Article 10 on the journalists' 'right of refusal' (hak tolak). Media consumers can use the right of reply to object to unfair treatment in the media (Romano 2003:67), while journalists can use the right of refusal to protect the identity of their news sources (Masduki 2003:81-2). Both articles are meant to strengthen relations between journalists and the public and secure the independence and ethical standard of the press.

Masduki (2003:171), being a university lecturer himself, believes the key to the improvement of Indonesian radio is high-quality journalism courses in tertiary education. According to Masduki (2003:177-8), the current curricula do not have a specific focus on radio journalism, but offer a methodology purely based on the principles of print journalism. He strongly recommends the institutions and their lecturers to have a better understanding of the characteristics of radio broadcasting, and also be prepared to send their students for practical training periods to local radio stations (Masduki 2003:173-4).

Local and international media institutions and NGOs have also emphasized the importance of education, and organized workshops on such diverse concepts as independent journalism, peace journalism, meta-journalism and interactive journalism. The following chapter will discuss these institutions and their activities and concepts in detail. The analysis will confirm that the trial and error period of contemporary Indonesian radio journalism - with its attempts at dialogism, and its focus on business and the public interest - is a dynamic, but far from complete or flawless project in reaction to the monological information culture of the authoritarian New Order regime. 



\section{Chapter iv}

\section{Radio journalism, transition, Indonesianness}

This chapter will explain how print and broadcast journalism during the New Order were affected by Bakhtinian heteroglossia, and how the institutional structures, journalistic concepts and programme genres of radio during Reformasi have reflected characteristics of Bakhtinian carnival. Firstly, it will analyse how the New Order regime used the concept of development journalism and different forms of legislation as tools to establish monologism as the dominant mode of discourse in the Indonesian public sphere. Secondly, it will discuss several strategies employed by journalists, audiences and other groups in civil society in heteroglossic reaction against the officially approved discursive monologism. Thirdly, it will identify alternative journalistic concepts and organization forms that have been developed during Reformasi, some of which have a dialogical character.

I will specifically focus on four institutions that have had considerable impact on the reform of the Indonesian radio landscape due to the nationwide scope of their broadcasts, training programmes, and other activities including the organization of competitions for radio stations. These institutions are Kantor Berita Radio 68H, Internews Indonesia, the Indonesia Media Law and Policy Centre and the Indonesian branch of the Friedrich Naumann Stiftung, which all have connections with or are aided by foreign organizations. In line with my discussion of the introduction and development of the idea of the public sphere in Indonesia, the case-studies will confirm that Reformasi cannot be understood as merely a local, uniquely Indonesian phenomenon, but has to be situated in the field of dynamic interactions between regional, national and international social, political and cultural forces.

\section{The New Order and development journalism}

During the New Order, Radio Republik Indonesia (RRI) and Televisi Republik Indonesia (TVRI) had monopolies on the production of news broadcasts. 
Commercial radio and television stations were obliged to relay the RRI and TVRI news bulletins and only allowed to produce so-called 'soft' news of their own, or news that was at least 24 hours after an event and never before any official reactions were known (Kitley 2000:255; Sen and Hill 2000:128). Soft news was also different from 'hard' news in style and content, as it was not supposed to contain harsh criticism of government affairs (compare Hjarvard 1998:216).

RRI and TVRI's style of broadcast journalism was a specific interpretation of development journalism, designed to serve New Order's five-year Pembangunan ('Development') programmes for advancing the country's economy. ' 'Development journalism' is an international concept, which allegedly has its roots in a seminar on the relationship between broadcasting, education and development organized by UNESCO in Bangkok, May 1967 (Tobing 1991:27). It was fully developed by the members of the Press Foundation of Asia (PFA) - a Manila-based non-profit organization for the training of journalists from Asian countries - who attempted to employ 'Western media ideology - including the separation of press and state - to advance their profession and, in turn, the development of their countries' (Tobing 1991:27-8). Journalism according to the original PFA concept did not rely merely on government sources reporting the positive effects of their own policies and activities, but had an independent and investigative character (Tobing 1991:47).

During the 1970s and 1980s, development journalism further evolved in the context of UNESCO debates on the imbalances in the global distribution of information resources. In these debates, Third World representatives pleaded for replacing or modifying the Western capitalist notion of 'free flow of information' with the new notion of 'balanced flow of information' in order to create and support a New World Information and Communication Order (NWICO). ${ }^{2}$ They argued that one of the ways in which NWICO could be achieved was through strict government control of the media (McPhail 1987:77, 105). Western UNESCO members, particularly the United States, were abhorred by the idea of national media borders and referred to article 19 of the United Nations' Universal Declaration of Human Rights, which guarantees freedom of opinion and expression as well as the right to use any type of medium to search, receive and distribute information. ${ }^{3}$

$1 \quad$ Tobing 1991:4; McDaniel 1994:224, 298-9; Kitley 2000:178-9.

2 McPhail 1987:73-6; Ansah 1986:65. At the 20th UNESCO General Assembly in Paris, 1978, their plea resulted in a compromise on a 'free and balanced flow of information', see McPhail 1987:105.

$3 \quad$ McPhail 1987:166; Ansah 1986:78; Muted voices 1996. Apart from budgetary disagreement, their dissent with the call for more state interference in communication affairs was one of the 
The protesting Western nations ignored the idea that inequalities in information resources can indeed lead to so-called 'media imperialism' (Ansah 1986), 'electronic colonialism' (McPhail 1987) or 'communications diplomacy and propaganda' (Hale 1975), and have the same impact as mercantile or military colonialism. Using radio, television or other media, nations no longer need to occupy or be physically present in other nations in order to dominate and influence their economic, cultural and political systems (Jurriëns 2004:12-4). Media imperialism includes the Frankfurter Schule notion of the 'aestheticization of politics', which refers to genres that are alluring and effectively hiding ideological messages, such as advertisements and entertainment programmes (Hale 1975:xiv).

Specifically regarding journalism, media scholar Paul Ansah (1986:65-6) has identified the following indices of media imperialism.

The imbalance in the flow of news between the North and the South; the distortions in the news about developing countries; the preponderant influence of the transnational news agencies; and the paucity of the horizontal flow of news among developing countries in the South, thus compelling people in those countries to see one another from the perspective of foreign correspondents whose value systems, ideological options and even prejudices are often reflected in the reports. (Ansah 1986:65-6.)

Apart from promoting national economic development, development journalism has also functioned as a tool for Third World countries to fight media imperialism, pursue cultural and informational autonomy and establish solidarity ties with other developing countries (Kitley 2000:178). At the same time, however, the national governments of many of these countries, including Indonesia, have used the developmental and anti-imperialist aspects of development journalism as an excuse to control the media and silence the opposition (Tobing 1991:35, 47). The Indonesian journalist and novelist Mochtar Lubis, who was a member of UNESCO's NWICO commission, clearly referred to his own country when he declared that it was

hypocritical that members representing some Third World countries demanded a balanced flow of information at the international level, but denied the same thing domestically, where information is vertical - one way - from the top down to the people (McDaniel 1994:287).

Philip Kitley (2000:190) considered the development journalism of TVRI news programmes as 'rituals of power' and part of the 'public relations' activities of

reasons why the United States withdrew from UNESCO in 1984. Only one year later, UNESCO lost another influential member, Great Britain, which took the same stand as the United States, see McPhail 1987:255, 277. 
state officials and departments responsible for official development projects. According to Kitley (2000:204), the way in which the programmes represented members of the public was merely 'a rite of incorporation, endlessly reinforcing the view that development is for all, while still maintaining the position that there is a complex, graded hierarchy of state officials whose job it is to control and manage, not on their own behalf, but pro bono publico'. In other words, TVRI's interpretation of development journalism was a form of monologism disguised as dialogism.

RRI applied this style of journalism in current affairs programmes as well as special bulletins on rural development. Programmes such as 'Siaran pedesaan' ('Village broadcast') and 'Jam rumah tangga' ('Household hour') were broadcast during the evening hours and contained information about the panca usaha, or 'five endeavours' of the Department of Agriculture ${ }^{4}$ and topics considered relevant to rural women such as health, family planning and food preparation (McDaniel 1994:224). To ensure that the public would take notice of this type of information in radio broadcasts and other media, the government organized formal Listener, Reader and Viewer Groups (Kelompok Pendengar, Pembaca dan Pemirsa) best known by the acronym of Kelompencapir (McDaniel 1994:239, 299).

During the early 1990s, the Department of Radio, Television and Film claimed that each of the approximately 72,000 Indonesian villages and cities had their own Kelompencapir. The groups discussed developmental information received from the mainstream media and participated in practical projects such as the building and maintaining of fish cultivation systems or chicken flocks (McDaniel 1994:239). Annual competitions were held for radio listeners to encourage greater participation in local development projects and facilitate the evaluation of radio programmes. In these contests, listeners had to answer questions about law and development and demonstrate skills related to village community life, such as the diagnosis of livestock illnesses, the preparation of foods and the tapping of rubber (McDaniel 1994:239-40).

The RRI programmes and off-air activities may have helped local communities in dealing with developmental issues. At first sight, the programmes, contests and listener discussion groups also seem to be similar to some of the interactive programmes and activities of the post-New Order period, such as the Friedrich Naumann Stiftung contests for radio stations (later in this chapter) and the Global FM contests for radio listeners (Chapter VIII). However, while today the public is often dialogically involved in the production of radio programmes and the organization of developmental activities,

4 These include better irrigation, use of high-yield seeds, use of fertilizers, fighting disease and pests, and improved soil cultivation, see McDaniel 1994:224. 
they were denied any serious creative opportunities or management responsibilities in monological, New Order-style development journalism. During Reformasi, broadcast journalism has also moved from the 'governmentsay-so journalism' of the Suharto period and closer to the original Press Foundation of Asia (PFA) development journalism concept, which values the government watchdog function of journalists as much as their developmental potential (Tobing 1991:47).

\section{Control and contestation}

Echoing some of the international debates on NWICO, New Order's official view on the press was that it had to be 'free but responsible' in contrast to the 'libertine' and 'irresponsible' Western press. This meant that the press had to act as a guardian of Pancasila ${ }^{5}$ and avoid sensational reporting about ethnicity, religion, race and 'inter-group' (that is, class) relations (suku, agama, ras and antargolongan, respectively, commonly abbreviated to the acronym SARA) ${ }^{6}$

Apart from promoting development journalism, the government used formal legal means and government institutions, particularly the notorious Department of Information, to control the written press, radio and television (Hill 1995:63-5). Indonesian media institutions were obliged to have official print or broadcasting licences, while their employees had mandatory membership of government-controlled professional organizations. The government could ban media institutions or force them to self-censorship by withdrawing, or threatening to withdraw, their licences. Journalists who did not follow the official rules ran the risks of intimidation, prison or even death (Sen and Hill 2000:56, 67-9; Hill 1995:37-54).

Newspapers and magazines could only be published by companies with a Surat Izin Usaha Penerbitan Pers (SIUPP, Press Publishing Company Permit) and journalists had to become members of Persatuan Wartawan Indonesia (PWI), which functioned as the only official Indonesian journalists' association from 1969 until 1998 (Sen and Hill 2000:53, 55; Hill 1995:67-73). Commercial radio stations had to become members of Persatuan Radio Siaran Swasta Nasional Indonesia (PRSSNI, Indonesian National Association for Commercial Broadcast Radio), which was responsible for broadcasting

5 Pancasila ('the Five Principles') is Indonesia's state ideology promoting the following five values: 1 . Belief in the one and only God, 2. Just and civilized humanity, 3. The unity of Indonesia, 4. Democracy guided by the inner wisdom of deliberations of representatives, and 5. Social justice for all the Indonesian people.

$6 \quad$ Sen and Hill 2000:53, 12; Hill 1995:16; McDaniel 1994:245; Kitley 2000:171; Jurriëns 2004:165. 
licence recommendations and functioned as the only official private radio organization from 1977 until 1998 (Lindsay 1997:113-4; Sen and Hill 2000:878). When commercial television came into being during the late 1980s and early 1990s, broadcasting licences all went to family members and close business partners of Suharto (Kitley 2000:230-1).

In spite of the ideological and legal restrictions on the media, the New Order could not prevent the alternative journalistic ideas and practices that were developed in Indonesia or introduced from abroad. While the bureaucracy used the counterbalancing of international information as a pretext for curbing domestic journalism, civil society used international news sources as a means to break free from the shackles of national propaganda and identity formation. In other words, the monoglossic boredom of official culture was resisted and renegotiated by the heteroglossic energies in society, which were inspired by unpredictable combinations of international, national and regional influences.

International news providers entered the country in several ways. Spillover transmission from Malaysia and Singapore could easily be picked up by standard television equipment in the Indonesian border regions of North Sumatra and West Kalimantan (Kitley 2000:220-1). Ironically, this spillover was facilitated by Indonesia's prestigious Palapa satellite. Palapa was launched in 1976 and turned Indonesia into the third country in the world, after the United States and Canada, with a domestic satellite. It was able to cover the whole archipelago and proved to be extremely successful in building national awareness (Kitley 2000:46-54). In the 1980s, affluent Indonesians who had installed their own satellite dishes could receive foreign news services transmitted by international satellites (Kitley 2000:221-4; Sen and Hill 2000:116-9). Foreign news and culture was also accessed on video cassette (McDaniel 1994:276-80; Kitley 2000:217-20) and later VCD and the Internet.7

Initially, the Indonesian policy makers attempted to stop unwanted foreign influences from penetrating and 'corrupting' Indonesian culture by taking measures such as a ban on commercials on national television (Kitley 2000:63-71). When they understood the ineffectiveness of those measures, they agreed with the establishment of domestic commercial television, which was believed to be easier to control and capable of distracting the attention of the Indonesian public from foreign information providers (Kitley 2000:229). Another incentive for domestic commercial television was Suharto's business partners, who urged the president for the expansion of commercial opportunities in the field of the media. ${ }^{8}$

$7 \quad$ Hill and Sen 1997, 2005:33-54; Sen and Hill 2000:194-211.

8 According to the critical radio and television talk show host Wimar Witoelar (1997:158), Suharto's business partners were not interested in television as such, but only regarded the 
Many Indonesian radio listeners tuned in to international broadcasters such as Radio Australia, Radio Nederland, BBC London, Deutsche Welle and Voice of America in order to enjoy different topics and viewpoints than the ones from RRI and other domestic media. ${ }^{9}$ In 1996, Jakarta-based Institut Studi Arus Informasi (ISAI, Institute for the Studies on Free Flow of Information) published a book with transcripts of international radio broadcasts that were recorded by Mohamad Sunjaya, a radio host and journalist from the commercial radio station Mara in Bandung. Sunjaya's (1996:vi) description of his experience of listening to the foreign channels after the 1994 shock-banning of the three esteemed current affairs magazines Tempo, Editor and DeTik (Hill 1995:41-3) illustrates the relevance of these channels to Indonesian listeners, especially in times of crisis.

Fortunately I had the hobby of listening to foreign radio stations such as Radio Australia, Radio Nederland, BBC London, Radio Voice of Germany (Deutsche Welle) and Radio Voice of America (Voice of America). I received the information I was hoping for from these foreign radio stations, which reached Indonesia with their broadcasts. During the period after the banning [of Tempo, Editor and DeTik], I listened to the news and comments from the foreign radio broadcasters daily. At dawn, sometimes still feeling sleepy, I listened to the quality comments from Joss Wibisono in his studio in Hilversum, the Netherlands. Until night-time, I listened to the news and interviews presented by Liston Siregar or Panusunan Simanjuntak [both at BBC London]. I took them with me wherever I went, I listened to the foreign radio broadcasts all day long. (Mohamad Sunjaya 1996:vi.)

Until the 1998 Decree from the Minister of Information, which officially allowed Indonesian radio to relay foreign broadcasts, these international news providers could only be listened to in private, if not in secret. Since the Decree, many commercial stations have made the international relays an integral part of their broadcasting schedules and also used the foreign journalistic styles as a source of inspiration for the production of their own news programmes.

As early as the late 1970s, Sunjaya with some of his colleagues from West Javanese radio pioneered so-called 'alternative radio journalism' (jurnalisme radio alternatif), or journalistic alternatives to RRI's monological development journalism. In 1979, they founded the Lembaga Produksi Siaran (LPS, Broadcast Production Institute) division of the PRSSNI branch in West Java. LPS produced a daily ten-minute 'Jurnal radio' ('Radio journal') on regional current affairs, which was co-produced and broadcast by the regional PRSSNI

medium as a business investment that could contribute to the growth of some of their companies' bigger plants, such as the petrochemical industry.

9 Imran Hasibuan and Sitok Srengenge 1996; Sen and Hill 2000:95; Browne 1978:318-38; Hodge 1995. 
member stations. ${ }^{10}$ The programme was tolerated by the local political rulers, in spite of its news content and probably due to its cleverly chosen journal format. Interestingly, Sunjaya (1996:vii) called the journal a form of 'development information' (informasi pembangunan), as it included information that came from and was targeted at community life in the West Javanese cities and villages. Unlike RRI's development journalism, which Sunjaya preferred to call 'salon journalism', LPS's programme combined an informal style with a critical approach, closer to the original PFA development journalism concept. Sunjaya was fired as editor-in-chief of LPS in 1991, after 'Jurnal radio' had reported on student demonstrations in Bandung.

Another example of heteroglossic resistance during the New Order was the establishment of AJI in 1994. AJI was founded by former journalists from Tempo, Editor, DeTik and several other media in protest against the 1994 bans and as an alternative to PWI (Sen and Hill 2000:55). Tempo journalists also continued the publication of their magazine on the Internet, a medium that was virtually beyond the control of the government. ${ }^{11}$ The Tempo editors even won two court cases challenging the Minister of Information's authority to impose the ban, although the Supreme Court eventually upheld the Minister's appeal (Sen and Hill 2000:6). The editors' bravery in going to court received much sympathy from the general public, including several military leaders and members of parliament (Hill 1995:42-3).

During Reformasi, the Indonesian news media have continued to contest New Order's cultural legacy by employing the latest communication technologies, establishing or strengthening bonds with international media organizations, redefining development journalism or developing alternative journalistic concepts and practices. News broadcast organizations with international links, such as Kantor Berita Radio $68 \mathrm{H}$, Internews, Indonesia Media Law and Policy Centre and Friedrich Naumann Stiftung, seem to have followed in the footsteps of the international radio channels that provided the Indonesian audience with alternative information and viewpoints during the New Order. A main difference with the pre-1998 situation is that foreign information sources, international journalistic cooperation and local nongovernmental news media are now officially accepted, integrated parts of Indonesia's re-opened public sphere.

10 Billy M. Sobirin, personal communication, 3-10-2001; Jurriëns 2004:58; Sen and Hill 2000:97.

11 Steele 2005:233-69; Sen and Hill 2000:200; Hill and Sen 2005:30 
KBR $68 \mathrm{H}$ and Internews Indonesia; Independent journalism, peace journalism, transparency

Kantor Berita Radio 68H (KBR 68H, Radio News Agency 68H) and Internews Indonesia are two radio news agencies, which were founded in Jakarta in 1999 and 1998, respectively. Both institutions made use of the enhanced freedom of speech and liberal media legislation of the early Reformasi period to secure their spot in Indonesian broadcast journalism. They do not actively broadcast, but produce programmes to be broadcast by client stations, usually commercial radio, which can receive the programmes on $\mathrm{CD}$ or via satellite or the Internet. The programmes include news bulletins, features and current affairs talk shows. Apart from producing programmes, KBR $68 \mathrm{H}$ and Internews Indonesia also organize broadcast journalism courses and provide equipment and funding to local radio stations. With their nation-wide network of client stations, they have become serious competitors of RRI and its regional branches.

KBR $68 \mathrm{H}$ was established with funding from The Asia Foundation, the Media Development Loan Fund and the Dutch Embassy, among others. The agency covers its operational costs with funding from international governmental and non-governmental organizations and with income from commercial activities. Internews Indonesia was founded as part of the US non-profit organization Internews Network. The network has twenty offices worldwide and is also active in states of the former Soviet Union and other (former) conflict areas such as Bosnia-Herzegovina, the Federal Republic of Yugoslavia, Israel, Palestine, Timor Loro Sae and Iran. Its donors include the United States Agency for International Development (USAID), the Dutch Government, the United States Information Agency (USIA), the Ford Foundation and Rockefeller Financial Services.

KBR $68 \mathrm{H}$ was founded by a community of internationally trained, cosmopolitan Indonesian journalists, artists and intellectuals who call themselves Komunitas Utan Kayu (Utan Kayu Community). Apart from the radio news agency, they run the radio station Radio $68 \mathrm{H}$, the discussion, training and publishing centre ISAI, the art gallery Galeri Lontar, the theatre group Teater Utan Kayu (TUK, Utan Kayu Theatre) and the bookshop Toko Buku Utan Kayu (Utan Kayu Bookshop), which are all based at 68H Utan Kayu Street. Goenawan Mohamad built the infrastructure for this community in 1994, when he bought four shops at Utan Kayu with the intention of creating a place for journalists and others to meet. This was a reaction to the banning of Tempo, which was headed by Mohamad as editor-in-chief. The formal structure of the Utan Kayu Community gave protection to those Tempo journalists who decided to go underground, uphold their own journalistic standards and continue publishing their banned magazine in electronic form on the Internet. 


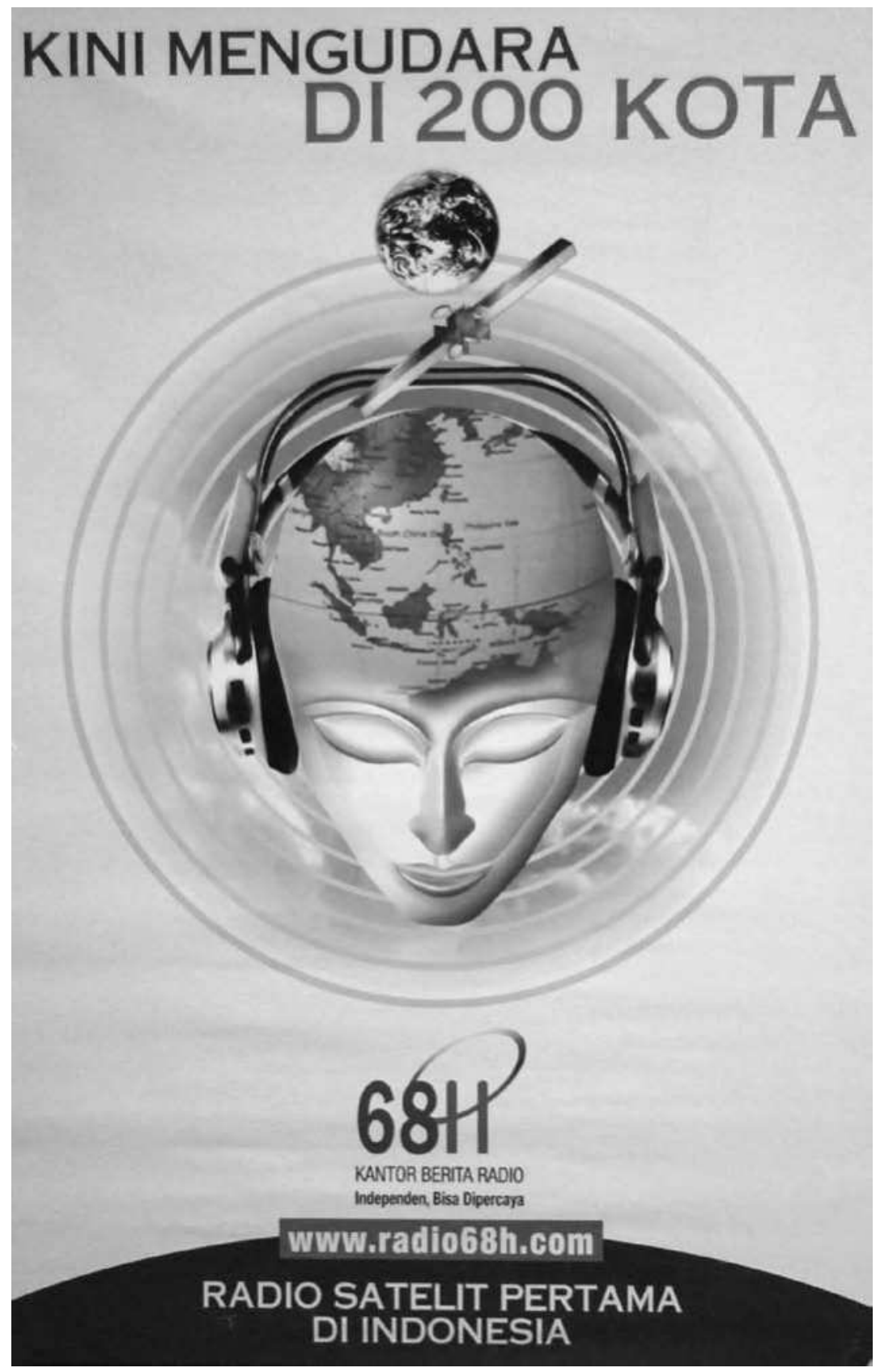

A poster illustrating Kantor Berita Radio $68 \mathrm{H}$ 's connectivity between radio and satellite technology 
The Utan Kayu complex and community revive memories of the infrastructure and ambience of the eighteenth century coffee houses, salons and table societies discussed by Habermas. At the centre of the complex is a kedai or small restaurant, surrounded by the theatre, the gallery, the bookshop, and the publishing and radio production facilities. The kedai is the place where Indonesian and foreign journalists, artists and scholars come together in order to have a coffee or a meal and participate in critical debates about topics such as journalism, art, literature, politics, religion and class. The conclusions or consensus reached during some of these discussions are made public through the radio broadcasts, current affairs magazines, literary works, theatre plays, paintings, sculptures, journalism courses, handbooks, interviews, speeches and other media of the Utan Kayu community.

In 2001, KBR $68 \mathrm{H}$ had a network of more than two hundred radio stations that made use of its programmes, while Internews Indonesia distributed its broadcasts to more than fifty radio partners nationwide. KBR $68 \mathrm{H}$ enables the exchange of information between different regions in Indonesia by broadcasting programmes produced by its regional client stations, thus providing listeners in Manado, North Sulawesi with news that was produced in Aceh, and listeners in Aceh with news from Bandung, West Java, for instance. This type of information-sharing constitutes a serious challenge to RRI's infrastructure of regional branches, which was the only national radio network permitted during the New Order. ${ }^{12}$

KBR $68 \mathrm{H}$ proudly makes the listeners aware of its extensive information network, as in the following jingle for the news bulletin 'Kabar baru' ('New information').

'Kabar baru 68H'. 'Kabar baru': listen to it carefully. Every hour from 6 a.m. until 9 p.m. Western Indonesian Time on your radio. A variety of reliable, independent and topical information, arriving faster from various corners of the fatherland. 'Kabar baru': economic problems, politics and social turbulences in various regions from Aceh to Papua. Listen to it carefully. Exclusively from Kantor Berita Radio $68 \mathrm{H}$, Jakarta. ${ }^{13}$

Member stations also try to gain prestige and commercial benefit from their cooperation with KBR $68 \mathrm{H}$. Suara Padang, for instance, always mentions the strong ties between 'Jakarta' and 'Padang' - or, implicitly, the political and

12 Santoso, personal communication, Jakarta, 18-10-2001.

13 'Kabar baru 68H'. 'Kabar baru': simak setiap jam mulai pukul 6 pagi hingga 9 malam WIB di radio anda. Beragam informasi aktual independen dan bisa dipercaya hadir lebih cepat dari berbagai penjuru tanah air. 'Kabar baru': masalah ekonomi, politik, pergolakan sosial di berbagai daerah dari Aceh sampai Papua. Simak hanya dari Kantor Berita Radio 68H, Jakarta (Jurriëns, transcription of a 14-10-2002 broadcast). 
economic centre and the regional periphery - when announcing a 'Kabar baru' relay from KBR 68H: 'From S. Parman Street 188 [the Suara Padang address] this was a syndication of Radio Suara Padang and Kantor Berita Radio 68H, Jakarta.' 14

In 2001, KBR $68 \mathrm{H}$ produced and transmitted fifteen programmes daily, consisting of twelve short news bulletins ('Kabar baru'), two longer news bulletins: 'Buletin pagi' ('Morning bulletin') and 'Buletin sore' ('Afternoon bulletin') and one special feature programme, including features about politics: 'Perspektif baru' ('A new perspective'), law: 'Reformasi hukum' ('Law reform'), arts and culture: 'Apresiasi' ('Appreciation'), human rights: 'Hak asasi manusia' ('Human rights'), the economy: 'Obrolan ekonomi' ('Economy chats'), the environment: 'Bumi kita' ('Our earth') and regional autonomy: 'Daerah bicara' ('The region talks').

Internews Indonesia has produced similar programmes. From 1999 until 2001, it had weekly features about topical socio-political problems: 'Kilas balik' ('Flashback'), gender issues: 'Jurnal perempuan' ('Women's journal') and the position of marginalized groups in society: 'Mata hati' ('The mind's

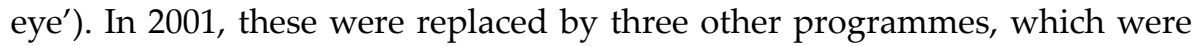
about the environment: 'Sahabat alam' ('Friends of nature'), public affairs: 'Suara bangsaku' ('The voice of my nation') and health: 'Sehat Indonesiaku' ('My healthy Indonesia'), respectively.

With their institutional structures and programmes, KBR $68 \mathrm{H}$ and Internews Indonesia have presented themselves as 'Third way' alternatives to government and commercial organizations. They are dedicated to representing the interests of the Indonesian public and promoting independent journalism, as illustrated by the following statement on KBR $68 \mathrm{H}$ 's website.

The Internet and satellite are only tools. What matters is the people behind these technologies. Radio $68 \mathrm{H}$ is supported by professional journalists who really understand the function of journalism. We are here to serve the interest of the public and meet its right on information. Amidst the euphoria of freedom, we are aware of the importance of clear, honest and clarifying information. Our journalists are trained to develop an independent attitude, to refuse to submit to [state] power or financial interests. ${ }^{15}$

This discourse is the discourse of Reformasi, expressed by people looking for a definitive break with Indonesia's totalitarian past and trying to steer the new process of reform. ${ }^{16}$ At the same time, it resembles or repeats the discourse of

14 Dari Jalan S. Parman 188 inilah sindikasi Radio Suara Padang dengan Kantor Berita Radio $68 \mathrm{H}$, Jakarta (Jurriëns, transcription of 2002 broadcasts).

15 http://news.radio68h.com/profile.php (accessed 18-10-2001).

16 A striking aspect of their statement is that satellite is considered merely a tool. As discussed 
international NGOs, including the concepts of independent journalism, civil society and the public sphere. The international Internews Network website, for instance, also contains statements about supporting 'independent media in emerging democracies' through 'innovative television and radio programming and internet content'. ${ }^{17}$ The institutional structures and journalistic practices of post-New Order institutions such as KBR $68 \mathrm{H}$ and Internews Indonesia can only be fully understood within the total spectrum of regional, national and global forces.

In their statements, KBR $68 \mathrm{H}$ and Internews Network both mentioned independent journalism as a key instrument for the press to serve the public interest, promote democracy, and uphold other Reformasi ideals. Independent journalism can be seen as one among several alternatives to the monological, government-controlled development journalism of the New Order. It can also be seen as a generic genre consisting of several subgenres, which each have their own style and focus points, but all share the value of journalistic independence.

$\mathrm{KBR} 68 \mathrm{H}$ and Internews Indonesia have also promoted their own version of another form of journalism that has come to the fore since Reformasi, so-called 'peace journalism'. Peace journalism can be considered as either an individual genre or one of the subgenres of independent journalism. The Internews Network website indirectly referred to peace journalism in the latter sense, by mentioning the usefulness of independent journalism as a tool 'to reduce conflict within and between countries'. ${ }^{18}$ The role of the media in conflict resolution has become prominent after the multiple outbreaks of communal violence in the Moluccas, Kalimantan, Sulawesi and other regions in the late 1990s.

National and international organizations have promoted peace journalism and related journalistic concepts about more specific problems, such as multicultural conflicts and discrimination against women, through the organization of workshops and the publication of books. For instance, the Indonesian NGO Lembaga Studi Pers dan Pembangunan (LSPP, Institute for Press and Development Studies) has published a series of journalism handbooks in cooperation with The Asia Foundation and USAID Jakarta, including titles such as Jurnalisme damai; Bagaimana melakukannya? ('Peace journalism; How to conduct it?', 2001), Konflik multikultur; Panduan bagi jurnalis ('Multicultural

\footnotetext{
before, during the Suharto regime the introduction of the domestic Palapa satellite (1976) was a highly prestigious project designed to serve the equally prestigious project of nation-building, see Kitley 2000:46-63. The people involved in $\mathrm{KBR} 68 \mathrm{H}$, representing a turn from the state to civil society, critically examine to what extent such projects are serving the public interest.

17 http://www.internews.org/about/about.htm (accessed 19-10-2001).

18 http://www.internews.org/about/about.htm (accessed 19-10-2001).
} 
conflicts; A guide for journalists', 2000) and Konvensi tentang penghapusan segala bentuk diskriminasi terhadap perempuan; Panduan meliput bagi jurnalis ('The convention for the abolition of every form of discrimination against women; A reporting guide for journalists', 1999). ${ }^{19}$

In one of her articles, Patricia Spyer (2005) illustrates how independent journalism and peace journalism have been translated from abstract concepts promoted by international and national NGOs into concrete Indonesian journalistic practices. The article focuses on the moral dilemmas of domestic journalists working in the Moluccas and other conflict areas in post-Suharto Indonesia. On the one hand, these journalists feel they have the right and obligation to freely report on a conflict. On the other hand, they are prepared to make compromises on their journalistic principles in order to minimize the risk of their reporting causing a conflict to increase. According to Spyer (2005:153), this moral dilemma has led to a 'proactive, stripped-bare form of reporting', which is devoid of any references to the religious, ethnic or other affiliations of the parties involved in a conflict. One of her cases is a newspaper journalist from Ternate, who explains that if a house of worship has been burnt down somewhere in the Moluccas, he will report on the event, but not mention whether the destroyed building is a church or a mosque (Spyer 2005:155).

This type of journalism seems to depart from the Reformasi ideal of 'transparency', as it is aimed at peace and safety rather than critical illumination (Spyer 2005:152). According to Spyer (2002:33), by leaving out the crucial details of an event, the peace-minded journalists deny the public the chance to come to terms with what has happened. Their reporting can lead to a 'spectralization' of conflicts and violence (Spyer 2002:33), potentially causing more conflicts and violence and completely reversing the original intentions of the journalists.

One can imagine that when violence comes to be seen as lacking an identifiable origin, when it lurks both nowhere and potentially everywhere, when its source is largely unseen, that this can engender a terrible fear. Without a clear object to fix on or turn to for reassurance, the response to such an engulfing fear may, in the right circumstances, be a recourse to violence. (Spyer 2005:160.)

Although, for very understandable reasons, this type of reporting exists in post-New Order Indonesia, it is certainly not the only type of peace journalism developed and practiced by Indonesian journalists. In certain radio talk shows and news bulletins, reporters or hosts explicitly mention the origins of

19 Darpan A. Winangun, LSPP publishing manager, personal communication, Jakarta, 10-102001. 
a conflict or the names of the parties involved, or deliberately take provocative, thought-provoking stands. This includes KBR 68H's talk show 'Hak asasi manusia' ('Human rights'), which, unlike the peace journalists that refrain from being transparent, addresses sensitive issues in a direct manner.

An example is the 9 October 2001 broadcast of 'Hak asasi manusia', which contained an interview between host Andi Budiman and liberal Muslim leader Muslim Abdurrahman on the US invasion in Afghanistan. The producers constructed the interactive programme to have a peaceful or cathartic effect by providing it with a provocative starting point for discussion. It started with Abdurrahman trying to understand and expressing certain sympathy for the motives behind the US invasion. Although many KBR $68 \mathrm{H}$ listeners disagreed with a fellow-Muslim country being invaded, Abdurrahman's respected status as local Muslim leader saved the discussion from an early death.

Before listeners could phone in and participate in the programme, the host warmed up the conversation with Abdurrahman by asking him about his personal opinion about the invasion. Abdurrahman responded that he could understand that the US government was angry and wanted to find and punish the people guilty of the attack on the World Trade Center. He did not consider the US actions a form of state terrorism or an attack on Islam, assuming the bombings were restricted to military targets and not designed to cause any civilian casualties. According to Abdurrahman, the Taliban were guilty of many crimes themselves and not representing the thoughts and ideals of Afghan society or the Islamic world in general. He also did not agree with the destruction of US assets or the intimidation of US citizens in Indonesia, especially since Islam was an accepted religion in the US and many US citizens went to the streets in protest against the war plans of their government.

The majority of listeners who participated in the interactive discussion was sceptical about the US and their allies, believing their main reason to go to war was economic interests. One of the listeners, Ms Yetti from Kediri, East Java, requested Abdurrahman to confirm whether he really sympathized with the allied forces, as she personally thought their decision to bomb Afghanistan was premature.

Yetti: I just noticed that you also said that the bombings conducted by America on, where on... on Afghanistan, were reasonably fair, according to you. According to me, they are not, because of America's own political attitude. You see how unfair they are towards Palestine. What America is doing now is apparently because the Afghan government does not want to indicate where Osama Bin Laden is, as there are still doubts about his case. While America already had the courage, so to say, to immediately bomb this place, thereby affecting the Islamic community itself. So if things flare up in Indonesia, I think it is rather... er... maybe because of a feeling of solidarity with fellow Muslims. But I would not agree if there would be destruc- 
tions of American assets by the Indonesian people in Indonesia. So, I would like to ask you about your attitude, how you just justified the American bombings.

Budiman: Fine, thank you, Ms Yetti. Maybe you can explain it again, Brother Muslim.

Abdurrahman: Well, Ms Yetti, I did not say that it was fair. But as long as America is selective in [bombing] military installations and so on, according to me, it is still in proportion, as they actually have a reason to search for 'the mass murderer' [in English] via the Taliban regime that protects him. Therefore, in my opinion, if it goes beyond military targets and the like, it cannot be justified, of course. ${ }^{20}$

This example shows that the hosts and invited guests of certain interactive radio shows have the courage to take provocative stands or address sensitive issues in a direct, 'transparent' manner. KBR $68 \mathrm{H}$ has promoted its own type of transparent peace journalism also in other programmes and jingles. The following jingle for the religious affairs talk show 'Agama dan toleransi' ('Religion and tolerance'), for instance, did not avoid but explicitly addressed the complex and sensitive issue of religious pluralism.

Should a person who is different be treated as an enemy? Can a difference in religion become a reason to quarrel? Listen carefully to the programme 'Agama dan toleransi' every Thursday 3:30 p.m. Western Indonesian Time. Together with me, Udin Apsar Abdallah, and renowned social personalities in Indonesia. Live from Kantor Berita Radio $68 \mathrm{H}$, Jakarta. ${ }^{21}$

20 Yetti: Saya tadi menyimak ya, Anda sempat berkata bahwa pengeboman yang dilakukan oleh Amerika ke mana, ke Afghanistan, menurut Anda itu cukup adil gitu. Kalau menurut saya kok nggak gitu. Karena sikap politik Amerika sendiri kan, Anda lihat ya, bagaimana tidak adilnya Amerika terhadap Palestina gitu. Sedangkan yang dilakukan Amerika sekarang itu kayaknya karena pemerintah Afghanistan itu tidak mau menunjukkan di mana Osama Bin Laden itu, karena kasusnya sendiri kan masih diduga gitu. Sedangkan Amerika sudah berani, istilahnya, langsung mengebom ke ini, yang dampaknya ke masyarakat Islam sendiri. Jadi seandainya ada gejolak di Indonesia, saya pikir ya cukup ini, mungkin karena rasa solidaritasnya terhadap sesama Muslim gitu. Tapi saya tidak setuju ya, apabila di Indonesia ini terjadi perusakan-perusakan yang dilakukan oleh masyarakat Indonesia terhadap aset-aset Amerika. Jadi ingin saya tanyakan bagaimana itu tadi, yang sikap Anda membenarkan pengeboman Amerika.

Budiman: Baik, terima kasih, Bu Yetti. Mungkin bisa dijelaskan kembali, Kang Muslim.

Abdurrahman: O ya, Ibu Yetti, saya tidak mengatakan bahwa itu adil ya. Tapi sejauh Amerika kemudian selektif ya untuk instalasi militer dan sebagainya begitu, menurut saya masih proporsional, karena mereka sebenarnya dengan alasan untuk mencari 'the mass murderer' itu melalui rezim Taliban yang protective terhadap dia. Oleh karena itu, menurut hemat saya, kalau lebih dari sasaran-sasaran militer dan sasaran-sasaran yang semacam itu, tentu tidak bisa dibenarkan (Jurriëns, transcription of a 9-10-2001 broadcast).

21 Apakah orang yang berbeda harus dimusuhi? Apakah beda agama dapat menjadi alasan untuk bertikai? Simak acara 'Agama dan toleransi' setiap hari Kamis pukul 15:30 Waktu Indonesia Bagian Barat. Bersama saya Udin Apsar Abdallah dan para tokoh masyarakat terkemuka di Indonesia. Langsung dari Kantor Berita Radio 68H, Jakarta (Jurriëns, transcription of a 14-8-2002 broadcast). 


\section{Indonesia Media Law and Policy Centre; Meta-journalism}

KBR $68 \mathrm{H}$ and Internews Indonesia have also promoted another type of transparency, namely media transparency, by developing broadcasting ideas and practices with a meta-journalistic character. Especially the Indonesia Media Law and Policy Centre (IMLPC), which started as the Media Law division of Internews Indonesia and developed into an independent institute in 2001, has given prominence to meta-journalism. IMLPC's mission is to enhance the professionalism of the Indonesian press, particularly the non-governmental broadcasting media with their short experience in news production. The IMLPC also informs the public about media legislation and negotiates with parliament and other relevant parties about the drafting of new media laws. Its activities include the organization of workshops, the publication of books and brochures, and the production of radio and television programmes on issues related to media law and policy. ${ }^{22}$

IMLPC's programmes are distributed as broadcast material on CD to local radio stations nationwide. I will focus on the $2001 \mathrm{CD}$ series 'Mengawal kebebasan pers' ('Pioneering/monitoring press freedom'), ${ }^{23}$ which was produced in collaboration with Dewan Pers (the Indonesian Press Council) and the Jakarta-based commercial radio station MsTri. The series was meta-journalistic, as it contained information about the rights and obligations of both journalists and audiences in the context of Indonesia's renewed press freedom, and aimed at enhancing the media literacy of the Indonesian public. Themes included 'violence against the mass media by the masses' (kekerasan terhadap media massa oleh massa, June 2001), 'how to correctly recognize a journalist' (bagaimana mengenali wartawan dengan benar, August 2001) and 'who holds responsibility in a talk show' (siapa yang bertanggung jawab dalam sebuah talk show, June 2001).

Each feature took approximately 25 minutes and consisted of the host's narrative, inserts with comments from media experts, background music and special sound effects. The host was Hinca I.P. Pandjaitan, media lawyer and head of IMLPC. From 2001 until 2006, Pandjaitan also hosted the weekly TVRI talk show 'Dewan Pers menjawab' ('The Press Council responds'), in which issues are addressed similar to those in the IMLPC series. In each radio feature, Pandjaitan's narrative was accompanied by Western classical music, probably to enhance the status of the programme and create a serious

22 Louis C. Schramm, personal communication, Jakarta, 18-9-2001.

23 Mengawal can either mean 'to pioneer' or 'to monitor', depending on whether it is derived from the noun awal ('beginning') or from the noun kawal ('guard, watch'). Thus mengawal enables a play with two concepts - pioneering and monitoring - that are both considered relevant in the early stage of Indonesia's renewed journalistic freedom during Reformasi. 
but pleasant atmosphere. Comments from experts and special sound effects were used to illustrate certain key issues or provide dramatic emphasis. For instance, when Pandjaitan talked about violence against the media, the sounds of broken glass and people screaming could be heard.

In the programmes, Pandjaitan tirelessly reminded journalists and the general public that their right to obtain and provide information was protected by 'the supremacy of the law'. While different parties with or without any legal knowledge have used and abused this phrase in the context of Reformasi, Pandjaitan always referred to specific legislation such as the Second Amendment to the 1945 Constitution of the Republic of Indonesia, the 1999 Press Law and particularly the 1999 Human Rights Law. Pandjaitan often quoted article 14 of the Human Rights Law, which states that 'every person has the right to seek, obtain, own, store, process and convey information by any type of medium available'. The frequent references to this type of legislation were to emphasize that the state was legally prohibited to monopolize and 'monologize' the news as during the New Order. At the same time, Pandjaitan used different case-studies to argue that journalists and the general public had to develop the right ethics and skills to avoid or counter media abuse, and give real meaning to the information freedom of the Reformasi era.

For instance, in the programme on the theme 'who holds responsibility in a talk show', Pandjaitan discussed the publication of President Abdurrahman Wahid's health reports by the commercial television station Metro TV. He posed the question whether Metro TV and its informants had acted ethically in accordance with their right to convey information or whether they were in breach of other legislation that prohibits people from offending the president of Indonesia. The programme did not solve the problem in a direct manner, but presented the details of the case as well as references to relevant legislation to encourage the listeners to search for answers themselves.

The programme on the theme 'how to recognize a real journalist' was also about the ethics of the journalism profession. It talked about wartawan gadungan ('fake journalists'), sometimes also called wartawan bodrek ${ }^{24}$ ('Bodrex journalists') or wartawan amplop ('envelope journalists'). ${ }^{25}$ These self-proclaimed journalists use fake press cards and force people to pay money for being interviewed for a story that will never be published. In the programme, Pandjaitan provided the public with practical and legal information about how to recognize and deal with the bogus journalists. Indirectly, he also criti-

24 Bodrek is derived from the painkiller brand Bodrex, which in one of its commercials depicts a mass of people hunting for the medicine. Fake journalists usually also operate in groups, hunting for money: Veven Sp. Wardhana, personal communication, 18-10-2001.

25 These are fake or 'real' journalists demanding envelopes with money from interviewees. 
cized 'real' journalists who, in order to earn something in addition to their official salary - which is often very meagre indeed - ask interviewees for envelopes with money in exchange for publicity.

The programme on the theme 'violence against the mass media by the masses' was about audience behaviour. It analysed why Indonesia during Reformasi has experienced groups in society expressing their anger with the media by threatening journalists or destroying their offices. The programme discussed and defended the rights and functions of the press and warned the public about sentences for violent behaviour against journalists. Pandjaitan also informed the listeners about alternative, non-violent ways of expressing their dissatisfaction with media reports, such as their 'right of reply' (hak jawab) and their right to demand rectification (hak koreksi).

IMLPC's programmes provide counter-evidence against Habermas' claim that mass culture and media segmentation would automatically lead to passive consumerism. The programmes live up to the expectations of the bourgeois public sphere to the extent that they are institutionalized, reach large parts of society through IMLPC's extensive network of client stations, and voice consensus among media scholars and practitioners involved in rational debates on state-related issues. Rather than contributing to the 'refeudalization of society' and the 'externalization of inner life', IMLPC and other postNew Order media organizations such as KBR $68 \mathrm{H}$ and Internews Indonesia have shown awareness of these Habermasian fears - which can manifest themselves in tangible instances of media abuse indeed - in their attempts at making audiences media literate and media savvy.

The IMLPC programme series addressed themes that were considered of immediate relevance to the Indonesian public struggling with the challenges of Reformasi, such as law reform, regional autonomy and human rights. At the same time, the themes and ways of discussion transcended the Indonesian situation and the borders of the Indonesian nation-state, as they were also derived from and applicable to situations and nation-states elsewhere. Similar to KBR $68 \mathrm{H}$ and Internews Indonesia, IMLPC receives inspiration from the civil society and public sphere idiom used by the extensive network of international NGOs of which it is a part. This means that the institutional structures and programmes of KBR $68 \mathrm{H}$, Internews Indonesia and IMLPC contradict Habermas' implicit claim that the boundaries of the public sphere follow the boundaries of the nation-state (Calhoun 1992:37) and call for the study of civil society and the public sphere in an international perspective. Some of the programmes express a type of patriotism that confirms Indonesia's national motto of 'unity in diversity' (bhinneka tunggal $i k a$ ), as reflected in titles such as KBR 68H's 'Suara bangsaku' ('The voice of my nation') and Internews Indonesia's 'Sehat Indonesiaku' ('My healthy Indonesia'). This is a new type of patriotism, or rather, 'cosmopatriotism' 
(Jurriëns and De Kloet 2007), which replaces the narrow nationalist rhetoric of the New Order and is fuelled by global or cosmopolitan experiences.

Similar to the criticism on Habermas' notion of the bourgeois public sphere, the programme content of KBR 68H, Internews Indonesia and IMLPC has been criticized for being elitist and exclusive, as it is based on the professional input of media insiders rather than experiences shared by the common public. In this respect, radio stations broadcasting programmes such as the pre-recorded episodes of IMLPC's 'Mengawal kebebasan pers' confront their audiences with finalized products and the consensus reached by others. As my analysis of 'Hak asasi manusia' shows, KBR $68 \mathrm{H}$ gives the listeners of regional stations relaying its talk shows the opportunity to phone in to the studio in Jakarta and have their opinions broadcast in the whole archipelago. These opportunities are limited, though, as conversations are predominantly between hosts and invited experts. There are also other constraints on participation such as the expense of telephone calls, which makes it more difficult for less affluent listeners from outside Jakarta to have their voices represented.

Local radio stations that broadcast $\mathrm{KBR} 68 \mathrm{H}$, Internews Indonesia and IMLPC programmes have also received comments from their listeners that the programme content is Jakarta-centred and often not relevant to local circumstances. Some of these listeners perceived the Utan Kayu Community as an elite society of intellectuals, separated from the rest of Indonesian society and, similar to Habermas' bourgeois public sphere, only accessible to people with the appropriate educational background or social network. ${ }^{26}$ In short, the three institutions and their programmes are dialogical in their attempts at enhancing the media literacy and ideological awareness of the public, but not in the narrower, more literal sense of directly involving audiences in debates on the media and other socio-political issues, due to the institutions positioning themselves as the representatives - rather than the presenters - of the public.

\section{Friedrich Naumann Stiftung; Contests, inserts and virtual interactivity}

Another influential international organization that has been active in promoting alternatives to the New Order's monological development journalism on a national scale is the Friedrich Naumann Stiftung (FNS). While KBR $68 \mathrm{H}$, Internews Indonesia and IMLPC have used programme production and jour-

26 This view was expressed by Yusirwan Yusuf, head of Suara Padang, Padang: personal communication 19-8-2002, and Kecuk Sahana, Production Manager of Unisi, Yogyakarta: personal communication 30-8-2001, among others. 
nalism workshops as their main strategies to develop Indonesian radio journalism, FNS has focused on the organization of annual competitions for best radio news programmes. The type of journalism promoted by FNS is 'virtual interactivity', which has its own specific dialogic qualities and is a fourth journalistic genre or sub-genre besides independent journalism, peace journalism and meta-journalism that has come to the fore since the late 1990s.

FNS was founded in Germany in 1958 by the first president of the Federal Republic of Germany, Theodor Heuss (1884-1963). Heuss named the organization after his political mentor, Friedrich Naumann (1860-1919), a leading liberal politician and one of the founders of the Weimar Republic (1919-1933). FNS 'sees itself as an agent of organized liberalism and is connected with the Free Democratic Party (FDP)' (Radio awards 2000b, 2001). The organization works in the spirit of Naumann, who believed that political education builds democracy by enabling the political participation and emancipation of citizens. FNS provides political education based on the principles of 'legal security and the rule of law, freedom of the media and of information, human rights, tolerance, pluralism, the application of the subsidiarity principle and market oriented economic reforms' ${ }^{\prime 27}$ The organization has a worldwide network with offices in Europe, Asia, Africa and North and South America.

FNS has worked in Indonesia since the late 1960s, 'mainly promoting political dialogue and strengthening civil society' (Radio awards 2000b, 2001). The Indonesian office has five departments: Administration, Publications, Government and Parliament, Law, and Journalism. The journalism department organizes training courses for radio journalists in cooperation with Deutsche Welle and provides a selected number of radio stations with broadcasting equipment such as computers, mixing panels and tape recorders. The department also organizes courses for journalists from the print media, including training on creating political cartoons. Every two months, Indonesian media representatives and parliamentarians are invited to go to Germany and meet German politicians and FNS members from other countries. These meetings give the invited guests the opportunity to conduct comparative research on topics such as how to organize general elections in a democratic way, and how to utilize the media in covering those events. ${ }^{28}$

A key element in FNS Indonesia's mission of disseminating democracy through broadcast journalism is its annual Lomba Program Radio, or 'Radio Programme Competition'. This competition, which has been organized since

27 With this particular suggestion for economic reform, FNS clearly links its liberal program to the ideology of capitalism. This may explain why it attributes an important role to commercial media institutions in the Indonesian process of Reformasi, apart from emphasizing their potential for high-quality news production.

28 Firqie Firmansyah, personal communication, 15-8-2002. 


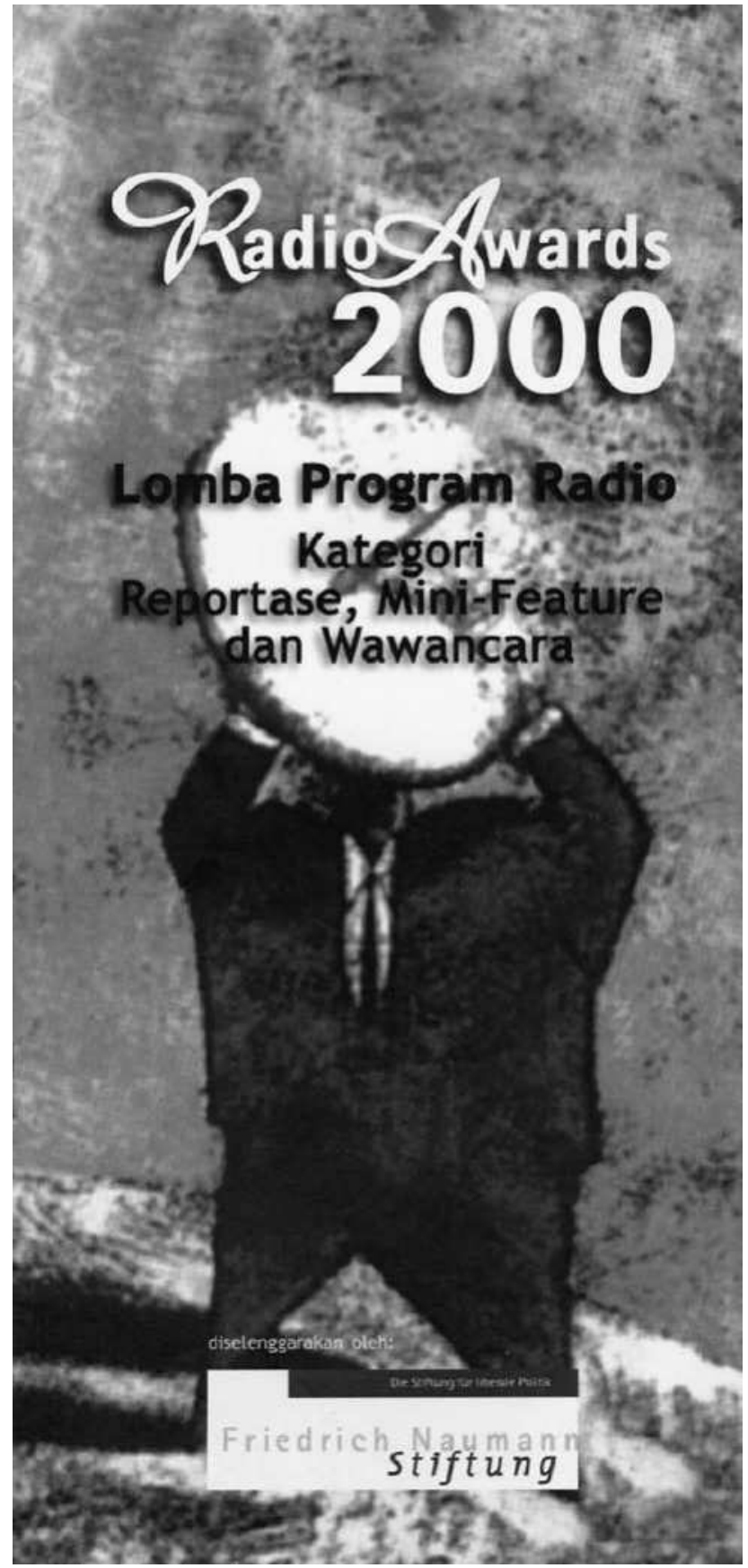

The Friedrich Naumann Stiftung 'Radio awards 2000' brochure 
1999, focuses each year on a different theme. In 1999 the theme was the general elections, in 2000 the performance of the members of parliament, and in 2001 regional autonomy. Radio stations compete with each other in three different categories: reportage, mini-feature and interview. Information on the competition and the conditions of participation are announced on posters and several mailing lists on the Internet, and sent to commercial radio stations and branches of PRSSNI and AJI. Stations that are interested in the competition have to send a recording and its transcript to FNS.

Each year, FNS Indonesia sends its jury's reports and cassettes or CDs with recordings of the prizewinning programmes to commercial radio stations nationwide. The jury's reports are informed by the political education ideals of the international NGO, but also the journalistic ideas and practices of local Indonesian radio stations such as Suara Surabaya. Suara Surabaya is not only where the head of the jury, Errol Jonathans, works, but also the radio station with the greatest prestige and longest history in news production in Indonesia. Suara Surabaya does not participate in the FNS competition because of Jonathans' involvement in the jury. By establishing connections with such a reputable radio journalist and exploiting the popularity of the competition format, FNS has successfully distinguished itself from other international and national media training institutions such as $\mathrm{KBR} 68 \mathrm{H}$, Internews Indonesia and IMLPC, and partially set a standard for Indonesian radio journalism.

The use of competitions for enhancing the quality of radio are embedded in what Karen Strassler (2004) has called an Indonesian 'culture of contests'. Strassler observes that contests are very common in Indonesia, especially for inviting popular participation in state programmes and commercial ventures. She describes how the New Order used contests for promoting state initiatives - ranging from family planning to tourism development and neighbourhood security watches - to the public. According to Strassler (2004:9), these types of contest, ' $[\ldots]$ while apparently celebrating achievement and innovation [...] actually function to reinforce existing structures of authority and to homogenize expression in accord with dominant ideologies'.

Examples from the New Order were the contests organized for radio audiences participating in Kelompencapir and state-sponsored competitions for Sundanese wayang golek (wooden puppet theatre). According to Andrew Weintraub (2001:99), the wayang contests 'represented attempts to recruit performers as vehicles for popularizing the government's program of national development'. Following the official evaluation criteria used for the contests, the performances had to 'thematize mental and spiritual development', 'communicate the instructions of development to the masses' and use language that was 'good and correct' (Weintraub 2001:93). Although the contests partially codified Sundanese wayang golek according to the New Order 
guidelines, dalang (puppeteers) also resisted state co-optation and continued to respond to the audience's taste for entertainment, communication and innovation. It was precisely dalang with the ability to respond to the expectations and concerns of the public which gained special popularity and prestige (Weintraub 2001:88).

New Order's political marketing rooted the tradition of organizing and participating in contests in Indonesian culture. During Reformasi contests have remained popular, including competitions for radio stations and outstanding radio listeners. Like the New Order contests, the Reformasi radio competitions are not free from ideology, as they are used to represent (foreign) political viewpoints or commercial interests. However, unlike the New Order contests, the latter competitions do aim, in Strassler's words (2004:9), at 'achievement and innovation' and attempt to be dialogical. In the contests for either radio stations or radio listeners, the participants are not merely asked to repeat or apply fixed ideas in a competitive situation, but encouraged to think about the very principles of radio communications and to suggest improvements and change of organizational forms, production modes, programme formats, journalistic concepts and audience behaviour. Most Indonesian media institutions are also aware of the ideological underpinnings of their cooperation with (foreign) political or commercial counterparts, and often show a very pragmatic attitude to those partnerships by calculating to what extent they serve the aims of the institutions themselves.

In the 2001 Friedrich Naumann Stiftung (FNS) competition with the theme of regional autonomy, 44 radio stations participated with 104 programmes in total. Although the organizers tried to stimulate the participation of radio stations from regions such as Sumatra, Sulawesi, Kalimantan and Eastern Indonesia, the majority of the participating stations (29) was from the traditional political and economic centre of Java (Radio awards 2001:2, 7). The head of the jury was Errol Jonathans, while the other jury members were specialists either in the field of radio journalism or regional autonomy.

While the jury's report of 2000 noticed an improvement in the quality of the competing radio programmes compared to the preceding year, the 2001 report regretted a decline in journalistic quality. According to the jury, it was difficult to find programmes that matched good knowledge of regional autonomy with good skills in radio broadcasting. Some programmes met the production criteria but failed to deliver satisfying analyses of regional autonomy, while other programmes provided useful discussions on the topic that were poorly presented. The jury believed that radio makers had to take into account four aspects of radio production to create successful programmes on regional autonomy. Firstly, they had to find a balance between radio's role as a public medium on the one hand, and its function as an institution with specific ideological or commercial interests on the other. Secondly, they had 
to have good knowledge of the topic, to be able to provide not only information, but also education, criticism and ideas for solutions. Thirdly, they had to be able to present the programme content in an attractive manner without compromising the quality of the information provided. Fourthly, they had to have a sense of radio's impact on the audience's perception and knowledge of the topic (Radio awards 2001:10-3).

In order to explain what FNS considered 'good' radio journalism particularly in terms of presentation, I will discuss two reports from that which they considered their most successful competition, the 2000 competition on the theme of 'our representatives in parliament'. The first report was on the firstprize programme in the reportage category produced by the former news agency Quadrant News Centre in Jakarta. The programme was about the outbreak of social unrest and demonstrations after an incident in which the army had taken several student activists into custody. What the jury appreciated about this programme was its ability to give the atmosphere of the event through the dynamic presentation of the reporter and the sound recording from the demonstration as well as a declaration of the local head of police.

The strength and unique quality of this reportage lies in the packaging, which presents several sound elements that are lively through the strength of the 'ambience' of the demonstrators' voices. The dynamics of this atmosphere are combined with a dynamic announcing technique that follows the rhythm of the event. An auxiliary element that strengthens the reportage is the sound bite from the declaration of the Head of the Metro Jaya Regional Police. Overall, the report flows harmoniously and is able to bring the listeners into the atmosphere of the demonstration, as if they were participants at the same location as the reporter. (Radio awards 2000b:8.)

The second report was on the third-prize programme in the same category. It was produced by Ria FM in Solo and discussed the false testimony by the chief director of the plantation firm PTPN IX in Central Java. The report was positive about the presentational style of the programme, particularly the way that the reporter explained the facts of the event. However, it also stated that the quality of the programme could have been enhanced if a greater sense of the atmosphere surrounding the event was provided.

The different evaluation of the first- and third-prize programmes shows that a central element in the radio journalism FNS attempts to promote, is the ability to provide the atmosphere of the reported event. Reporters can give the audience a sense of atmosphere by including sound-bites from people directly involved in the event, such as eyewitnesses, or ambient sounds from the event itself. In the jargon of Indonesian radio journalists, these sounds and sound-bites are called sisipan or 'inserts' (the English term is sometimes used) as they are inserted in the narrative of a reporter or programme host 
(Masduki 2001:31-3; Jonathans 2000:81). Inserts are a relatively new phenomenon in Indonesian radio journalism as they were rarely used in the formal and distanced RRI bulletins, which all commercial stations were obliged to relay during the New Order. ${ }^{29}$ According to Masduki (2001:31-2), inserts have enhanced the credibility of Indonesian news programmes and made them more 'factual' (factual), 'lively' (hidup), 'attractive' (atraktif) and 'sharp' (tajam).

The following description of the first-prize programme in the category mini-feature of the 2000 competition provides a concrete example of the function of radio inserts. The mini-feature produced by KBR $68 \mathrm{H}$ was 'MPR tetap pertahankan TNI/Polri hingga 2009' ('MPR maintains TNI/Polri until $\left.2009^{\prime}\right)$. It was on the proposal of one of the People's Consultative Council (Majelis Permusyawaratan Rakyat, MPR) committees to extend the position of the Indonesian National Army (Tentara Nasional Indonesia, TNI) and the Police of the Republic of Indonesia (Polisi Republik Indonesia, POLRI) in the council until 2009. The army and police had seats in MPR and Dewan Perwakilan Rakyat (DPR) as part of their dwifungsi ('dual function', that is, both security and politics-related) since 1960 (Vatikiotis 1993:60-91). In the light of Reformasi and the democratization of the political system, this dual function was under reconsideration.

The mini-feature reported several reactions in politics and society about the proposed plan of the MPR committee. First, the female presenter reported on the political parties that were in the process of voting for or against the proposal. Then her discussion was that groups in society were disappointed that the position of the army and police in MPR would be maintained. Before and after this section, sounds from students' demonstrations in front of the MPR building could be heard, including slogans such as 'Usir, usir TNI' ('Chase away, chase away the army'). The presenter continued with summarizing the opinion of one of the members of the Partai Demokrasi Indonesia-Perjuangan (PDI-P, Indonesian Democracy Struggle Party) faction who supported the proposal, as he thought that the army and police would otherwise establish their own political party and become even more influential in politics. The summary was followed by sound-bites from the original statement of the PDI-P member. Finally, the presenter discussed the opinion of the Minister of Defence, Yono Sudarsono, who was against the plan and wanted the army and police discharged immediately from their political functions. This final part of the feature also included sound-bites from Sudarsono's statement.

On the audio-cassette with recordings of all the awarded programmes, the FNS jury praised the producers of the mini-feature particularly for their selection of information sources and ability to display the atmosphere. 
The strength of this feature lies in the texture of several audio elements that feature human interest perspectives. The ambient sounds of demonstrators who refuse the decision complement the depth of the discussion about the topic. The choice of balanced and credible informants constitutes the other strength of this programme. ${ }^{30}$

The jury's reports made it clear that, according to the FNS standard, 'liveliness' and 'attractiveness' - as mentioned in Masduki's description of sisipan - referred to the function of inserts to stimulate the imagination of the audience and give them the impression of being physically present at the reported event. Masduki's other notions of 'factuality' and 'sharpness', however, are more complicated when applied to cases of sisipan in Indonesian news programmes. They probably refer to the fact that radio stations also use inserts to claim that their reports are 'live' and that their reporters are on the spot of the reported events. Factuality and sharpness also imply the Reformasi ideal of transparency, or the fight against the legacy of New Order leaders covering up the 'real' facts.

Mora in Bandung is an example of an Indonesian commercial radio station that has partly based its image on notions of factuality and sharpness or liveness in news reporting. Mora is known for its bulletins with local news, which are broadcast every half hour. In these bulletins, the studio hosts have direct contact with Mora reporters in the field. The jingle that accompanies the reports contributes to the image of the radio station as a fast and reliable news provider. The jingle suggests speed and liveness by announcing the reports as 'interruptions' (interupsi). It underlines the accuracy of the reports by stating that the information they contain has been 'checked' (teruji). The news bulletins themselves have inserts with background noises and on-the-spot interviews to signify the presence of the Mora reporters at the site of the reported events.

When radio stations use inserts to suggest liveness as in the case of Mora, they give the illusion of providing a window on the world, as if the sounds they transmit are undistorted and the listeners can hear for themselves what is happening on the site of the event. However, such usage of inserts poses questions about the authenticity of the represented sounds and sound-bites, as they are usually edited and are thus distorted and manipulated in the process of mediation. By stressing immediacy or transparency, the stations seem to obscure their own role in the process of mediation. In other words, inserts do not necessarily make a report more 'factual' and 'sharp' than monologic narration.

30 Kekuatan feature ini ada pada rajutan berbagai elemen audio yang menampilkan sisisisi minat insani. Suara-suara ambience demonstran yang menolak keputusan ini melengkapi kedalaman bahasan topik. Pemilihan nara sumber yang berimbang dan kredibel merupakan kekuatan lain program ini, see Radio awards 2000a. 
Nevertheless, irrespective of whether they are used to create immediacy, inserts certainly make the audience feel more engaged with the news event. Where liveliness is concerned, engagement is triggered by the programme's presentation and the allure of the sheer materiality of the inserted sounds. In the case of a report being seen as live, this is mainly based on the information value of the represented event and the supposed transparency of the inserted sounds and the programme as a whole. In other words, inserts stimulate a kind of 'virtual interactivity' in which the audience responds emotionally and intellectually to a programme and news.

In engaging or involving the audience, this virtual interactivity is dialogical and breaks with and reacts against the monologism and detachment of the journalistic styles and other public discourse officially approved by the New Order. It is not necessarily dialogical in the Bakhtinian sense of enhancing the media literacy and ideological awareness of the audience, and certainly not dialogical in the narrow sense of 'real' interactivity. 'Interactive journalism' that gives listeners the opportunity to directly contribute to broadcasts constitutes a different, fifth dominant genre or subgenre in post-Suharto radio journalism, and will be discussed in detail in the following chapter. 


\section{Chapter v}

\section{The actors of interactive radio journalism}

Indonesian radio has witnessed the development of 'interactivity' since the late 1980s. ${ }^{1}$ Interactivity here refers to 'talk-back' or 'phone-in' radio, or interactivity in a narrow sense, in which the audience has direct on-air contact with the host and other participants and actively contributes to the production of radio discourse by using the medium of the telephone. Indonesian radio stations have been interactive in a broader sense by targeting specific audiences or market segments. These audiences or market segments are partly created by the radio stations themselves, as they develop in response to the radio stations' own perceptions of groups and needs in society.

Jennifer Lindsay (1997) has demonstrated how private radio throughout Indonesian radio history has appealed to local audiences by focusing on local broadcast content, including regional music and performing arts. Krishna Sen (2003:575) has called this broader type of interactivity 'socially produced interactivity' contrasting it with the 'technologically given one of the Internet'. However, this observation does not address the problem of where technology ends and social production begins, nor does it take into account that 'local audiences' and 'regional culture' have been the products of marketing strategies of private radio as far back as the 1930s. ${ }^{2}$

This is not to underestimate the capability of Indonesian radio to simultaneously create and represent trends and traditions that are alive on a regional or local level, due to techno-cultural features such as the orality and aurality of radio communications, the instantaneousness of broadcast transmission, the relatively cheap production costs of programmes, and the cheapness and portable size of radio receivers. During the New Order, radio stations also developed a close relationship with local audiences, not always devoid of political content, as an effect of government policies that restricted the reach of private radio broadcasts. Ironically, these policies were developed out of

$1 \quad$ Samuel 2002:309; Sen 2003:584; Lindsay 1997:116; Jurriëns 2007.

2 This was the period of the so-called 'Eastern' radio stations or radio ketimuran, private stations monitored by Dutch colonial rule that catered for an autochthonous market, see Lindsay 1997:109; Sen and Hill 2000:81. 
fear of the potentially political impact of private radio. ${ }^{3}$

Although only Radio Republik Indonesia (RRI), the state radio station, was allowed to have a national scope and broadcast news, private radio stations found creative ways to circumvent regulations and produce their own news and information, especially by exploring their 'social interactivity'. They inserted commentary on regional current affairs in radio drama, 'soft' information bulletins and interviews with studio guests and listeners. As mentioned before, the Bandung radio station Shinta produced 'Dongeng plesetan', a Sundanese parody-drama on West Javanese politics and society (Jurriëns 2004:147-66), while a restricted number of other stations, including Trijaya (Jakarta), Mara (Bandung), Unisi (Yogyakarta) and Suara Surabaya (Surabaya) had the courage to pioneer talk-back programmes on topical issues (Samuel 2002:308; Sen 2003:580-2).

Today, the number of current affairs programmes on Indonesian radio is still relatively small, as most commercial stations lack the financial means or journalistic skills required for news production. The majority of talk-back programmes are concrete examples of an Habermasian 'externalization of inner life', in which listeners exhibit aspects of their private life, while participating in activities such as requesting songs and sending greetings to members of an audience of overhearers. Due to their lack of political content, the programmes can be considered as instances of 'phatic performance', a discursive category Ben Arps (2003) has linked to the sending of personal messages on air in Banyuwangi, East Java. Arps, contradicting Habermas, demonstrates that such activity is less trivial than it may seem and serves important social goals, as it enables interaction between radio listeners, provides the participants with the pleasure of being heard or overheard, and creates or confirms social networks.

At the same time there has been a progressive growth in talk-back radio that is of a shared public interest not only because of the social functions it serves, but also because of the social issues it represents. The broadcast content of this latter type of talk-back radio includes topics such as current affairs, art and culture, health and sexuality, the environment, religion, law and regional autonomy. With slogans such as 'Informasi dari anda, untuk anda' ('Information from you and for you'), ${ }^{4}$ commercial radio stations have attempted to involve the audience in news and information production, reduce programme production costs, compensate for the lack of professional radio journalists and make the news and information relevant to local or regional circumstances. 
In this chapter, I will not explore further the potentially subversive aspects of 'phatic performance', but focus on current affairs talk shows. After a general introduction about the 'audience participation programme' genre, I will discuss the role and function of the different actors involved in Indonesian talk-back radio since the late New Order, including hosts, invited experts, listeners, reporters, editors and gatekeepers. In Chapter VI, I will analyse the effects of the on-air behaviour of these participants and describe what Indonesian interactive radio discourse does in terms of the journalistic and social practices it has brought into being. Chapter VII will specifically focus on the group of the listeners and its experiences in interactive radio journalism.

The genre of the audience participation programme

I will use Sonia Livingstone and Peter Lunt's excellent work on television talk shows as a framework for the analysis of Indonesian interactive news radio. According to Livingstone and Lunt (1994:37, 175), the audience participation programme is a genre that challenges traditional distinctions in discourse theory, for instance between text and audience, production and reception, sender and receiver, interpersonal communication and mass communication, current affairs and entertainment, ideas and emotions, and argument and narrative. It combines elements from various media genres, including current affairs, documentary and soap opera, but is at the same time distinctively different from each of them.

The audience discussion or participation programme is not quite current affairs or consumer affairs though it deals with current issues as they affect ordinary lives. It uses experts but is not documentary. It shows the impact of current issues on ordinary people's everyday lives through story-telling but is not soap opera. Like the soap opera, it constructs the viewer as community member and repository of common sense, but it takes issues beyond the private domain of the domestic and local, for the viewer is also constructed as citizen, with a duty to be informed about and act upon the wider world. (Livingstone and Lunt 1994:38-9.)

The discussions between participants in audience participation programmes also comprise different narratives or debate styles, such as the classical debate', 'the romantic narrative', 'the therapy session', or combinations of one or more of these (Livingstone and Lunt 1994:56). In the classical debate, audience members and experts discuss social problems with each other under the guidance of a host. Each party receives equal opportunity to present their opinion in a rational and orderly manner. The discussion partners aim at reaching a conclusion by the end of the programme (Livingstone 
and Lunt 1994:57-8). This style of debate can be found in the Trijaya talk shows. The romantic narrative does not necessarily aim at a conclusion, but rather encourages ordinary people to talk about their personal experiences. Audience participation programmes evolve into therapeutic sessions when the host helps audience members to express their emotions and overcome their problems (Livingstone and Lunt 1994:61-8). In the talk shows of Jakarta News FM and Mora, such self-disclosure does not only serve to cure purely personal problems, but also social diseases of Reformasi.

The audience participation programme with the classical debate style shares several characteristics with Habermas' bourgeois public sphere, as it constitutes an institutionalized, publicly accessible forum where rational debate takes place and consensus may be reached. Livingstone and Lunt (1994:58) rightly put the publicness of these debates into perspective by addressing the controlling power of the host, the prominence of experts over lay participants and the restricted opportunity for listeners to express themselves. These observations partly hold true for Trijaya's concept of 'multisided journalism' (see Chapter VI).

Livingstone and Lunt (1994:160-1) argue that many audience participation programmes are in fact manifestations of a different kind of public sphere, the so-called 'oppositional public sphere'. In the oppositional public sphere, people express opinions that are rich in diversity, validate accounts of lived experience in the life-world, and search for compromise rather than consensus. According to Habermas (1989b:236; Livingstone and Lunt 1994:174), this alternative type of public sphere is subject to corruption and refeudalization because it allows the representatives of official power or commercial interest to engage in direct dialogue with normal citizens, thereby transforming publicness into public relations. My example of radio station Mora (Chapter VI) will illustrate that such refeudalization is indeed one of the symptoms of the Reformasi radio landscape.

On the other hand, the dialogue as manifested in audience participation programmes 'may also afford opportunities for accountability, the identification of contradictions between policy/expertise and everyday life, space for ordinary people to generate and validate common experiences, and so forth' (Livingstone and Lunt 1994:174). According to Livingstone and Lunt (1994:32), the programmes usually do not represent a public unified by the successful outcome of communication between different parties, as would be the case in the bourgeois public sphere, but rather diverse publics exploring the possibilities and restrictions of communication. This exploration of the rules and boundaries of discursive interchange can be found in Indonesian radio talk shows and contests for listeners that aim at enhancing the media literacy of audiences. 


\section{Hosts addressing their audiences}

The participants in radio discourse play different roles and fulfil different functions in accordance with the profile of a radio station and the narrative(s) or debate style(s) of a specific programme. Two of the main functions of a programme host are to sell the image of a radio station by addressing and attracting listeners, and to regulate the flow of radio discourse by guiding interactive discussions and choosing the right moments to insert music and commercials. A direct and effective manner for hosts to establish close emotional or ideological ties with the listeners, and identify them as or turn them into their listeners, is the use of clearly identifiable modes of address. In general, Indonesian radio hosts use two different modes of address: either referring to the listeners' status or main activities, or expressing a friendship or family-like relationship between the radio station and the audience.

Examples of the first mode of address are used by the hosts of the commercial stations El Shinta (Jakarta), Trijaya (Jakarta) and Unisi (Yogyakarta), who address their listeners as eksekutif muda ('young executives'), profesional muda ('young professionals') and intelektual muda ('young intellectuals'), respectively. ${ }^{5}$ Although they address the listeners as 'young', youth is not necessarily their main target audience. Young rather refers to 'dynamic', to people who live in a cosmopolitan environment such as Jakarta or a cultural and educational centre such as Yogyakarta, are willing to develop, and capable of adapting themselves to changing circumstances. 'Executives' and 'professionals' represent businessmen and office people, and 'intellectuals' students or people with a higher educational background. These modes of address may boost the self-confidence of the listeners and make them feel part of a larger community of people with similar backgrounds. At the same time, the modes of address are meant to provide the radio stations with a reputation of high quality, as they suggest that the listeners have to have certain skills to be able to follow the programmes, or that the programmes may further enhance the listeners' professional and intellectual abilities.

The hosts of other radio stations use more informal modes of address, referring to their listeners as friends of relatives. For instance, at Global FM (Tabanan) saudara ('brothers and sisters') is used, at Mora (Bandung) sobat ('friends'), at Suara Surabaya (Surabaya) kawan ('friends' or 'comrades') and at Suara Padang (Padang) bapak ibu sahabat setia ('ladies and gentlemen, loyal friends') ${ }^{6}$ With these modes of address, the hosts make it clear that they are trustworthy conversation partners, who understand and respect the opinions 
and way of life of their listeners. The listeners are turned into members of a radio community, who do not merely share the same professional or intellectual interests, but also the same feelings and emotions. Hosts also use such modes of address to confirm the position of their radio stations as 'the voice' of a region - reflected in names such as Suara Surabaya ('The Voice of Surabaya') and Suara Padang ('The Voice of Padang') - and strengthen the regional attachment of the listeners, exploiting the fact that the region in Indonesia is a geographical or administrative concept that bears the connotations of a family unity or friendship bond.

In Indonesian radio talk shows, not only standardized modes of address are used, but also more personal references for introducing oneself or welcoming someone else. Hosts, listeners, experts and other participants usually take time in informing each other about their names, the places where they live and other noteworthy personal details. These introductions can be seen as media equivalents of the Indonesian social tradition of mengikat silaturahmi (establishing friendship bonds), in which new connections are established or old friendship bonds reconfirmed. However, after the slow and relaxed introduction ceremony, newly introduced persons often quickly change the mood of the conversation by accelerating their speech and expressing their opinion in sharp, clear and serious wording. ${ }^{7}$

Modes of address in a literal, narrow sense are just one set of rhetorical devices used by radio hosts in order to contribute to the construction of the image of a radio station and the creation of a community of listeners. They use other devices that meet the requirements of specific speech situations or programme genres, and confirm the talk show host in a specific role. A host can play such diverse roles as 'the chair of a debate, the adored hero of a talk show, a referee, a conciliator, a judge, the compère of a game show, a therapist, the host of a dinner-party conversation, a manager or a spokesperson' (Livingstone and Lunt 1994:56). I will provide concrete examples of Indonesian hosts in three of their major roles: 'consoler-therapist' (in programmes of Jakarta News FM and Mora), 'star-hero' (Jakarta News FM's host Ratna Sarumpaet) and 'chair of debate' (in Trijaya's programme 'Jakarta first channel', see Chapter VI). I will also describe the roles of invited experts, editors and gatekeepers in Indonesian radio programmes.

An example of the host as consoler-therapist can be found in Jakarta News FM's two-hour Saturday morning talk show 'Ngobrol sama Dono' ('Chatting with Dono'), which is hosted by the radio station's head Nor Pud Binarto together with a comedian known as Dono Warkop. In the show, the two hosts

7 I noticed this in talk shows of Trijaya, El Shinta, Jakarta News FM (all three in Jakarta), Mora, Mara (both in Bandung), Unisi (Yogyakarta), Suara Surabaya, SCFM (both in Surabaya) and Global FM (Tabanan). 
discuss a news item of the week in a very relaxed and humorous manner, with possibilities for listeners to phone in and express their own opinions in a preferably similar mood. By discussion and releasing the tension from controversial issues, the hosts attempt to free people from their frustrations and console them. The hosts also have the flexibility to insert commercial breaks or musical interludes whenever they feel that the participants in the discussion become too emotional or tired, or otherwise lose direction. Usually they announce the necessity of such mood-changing breaks or interludes with the subtle, tranquilizing phrase 'let's have a break now' (break dulu). ${ }^{8}$

The hosts of 'Ngobrol sama Dono' follow in the footsteps of a long tradition of Indonesian radio hosts who, almost similar to the way in which traditional Malay consoler-storytellers (penglipur lara) tell tales to relieve or amuse their audiences (Maier 2004:92), attempt to console listeners or distract them from their daily sorrows. Whereas consolation before Reformasi was mainly offered in broadcasts with entertainment such as music, radio drama and quizzes, now it is also provided in programmes with a journalistic edge. The consolation offered in 'Ngobrol sama Dono' can be seen as a specific manifestation of peace journalism, in which social problems are not avoided, but addressed and put in a peaceful therapeutic or humorous perspective.

A similar kind of peace journalism can be found in the talk show 'Mora interaktif' ('Interactive Mora') produced by the commercial station Mora in Bandung. For instance, in a 27 September 2001 broadcast on the US invasion in Afghanistan, the host urged the listeners not to get involved in 'sweeping', the activity of harassing foreigners in Indonesia. The host used several consoling devices to make the listener-participants in the interactive dialogue feel at ease as well as to lessen tensions in society at large. He created a relaxed and intimate atmosphere by speaking slowly, using a soft voice, mixing codes between Indonesian and Sundanese, using Sundanese expressions such as the hospitality device someah ke semah ('be friendly to guests'), making jokes and spreading peaceful messages. ${ }^{9}$ One of the listener-participants joined in code-switching and joking by making a wordplay or plesetan of the expression 'sweeping', thus pointing to the very meaninglessness of violence against foreigners.

8 Based on recordings of 2001 broadcasts and Nor Pud Binarto, personal communication, Jakarta, 11-8-2001.

9 While the Mora hosts try to be therapeutic by calming down the audience, other hosts rather attempt to make their listeners cope with the problems of daily life by 'energizing' them. The hosts of commercial youth stations such as Swaragama in Yogyakarta represent joy and energy by playing loud pop music and using fast speech, trendy language (bahasa gaul) and much laughter. 
Host (H): [In Indonesian] Bandung citizens, all of us er, [in Sundanese] please don't participate in 'sweeping'. There is no reason at all to 'sweep' American tourists here. [...] What is 'sweeping' actually? Don't do it, friends of Mora, [in Indonesian] we don't need to hate other people. No, towards other people, we, the West Javanese people, will surely remain er, [in Sundanese] what's the expression, 'friendly to guests'. There is that expression 'be friendly to guests'. What does it mean? Hello?

Listener (L): Hello?

$\mathrm{H}$ : Yes, good afternoon.

L: Good afternoon.

H: Who am I speaking to, Sir?

L: Budi.

$\mathrm{H}$ : Hi Mr Budi, how are you?

L: Not too bad. I am still on the road.

$\mathrm{H}$ : Alright. Mr Budi, are you friendly to guests?

L: You must be joking!

$\mathrm{H}$ : Hehehe. But not after guests have been at our place for seven days in a row, right, hehehe.

L: What about that 'sweeping', 'sweeping' [is something you should do] in a pool.

H: Hehehe, that's 'swimming', Sir, hehehe. You're just twisting it.

$[\ldots]{ }^{10}$

While this type of dialogue may not meet the criteria of Habermas' critical-rational debate nor explicitly address the deeper causes of the war in Afghanistan, both host and listeners showed that they tried to come to terms with the effects of the war by using Bakhtinian parody, which undermines traditional conventions in language and society and illustrates or contributes

10 H: Warga Bandung kita semua, ah ulah ikut-ikutan sweeping atuh. Teu puguh-puguh ada turis Amerika di ieu disweeping. [...] Naon atuh 'sweeping' teh? Urang mah ulah, ya, sobat Mora, kita mah tidak perlu ya, untuk benci terhadap orang. Kemudian apa sama orang, tidak, kita tuh tetap ya, sebagai orang Jawa Barat anu, naon kitu istilahna teh, 'someah ka semah'. Ieuh, aya istilah eta teh someah ka semah, maksudna teh naon? Halo?

L: Halo?

$\mathrm{H}$ : Ya, wilujeng wengi.

L: Wilujeng wengi.

$\mathrm{H}$ : Sareng saha ieu, Pa?

L: Budi.

H: Ha Pa Budi, damang?

L: Alhamdulillah, di jalan keneh.

H: Oh kitu. Pa Budi, someah ka semah?

L: He, atuh!

H: Hehehe. Kecuali semahna tos tujuh dinten di urang terus nya, hehehe.

L: 'Sweeping', teh kumaha, 'sweeping', di kolam renang.

$\mathrm{H}$ : Hehehe, 'swimming' atuh Pa, hehehe. He, sok dibolak-balik wae.

[...] (Jurriëns, transcription of a 27-9-2001 broadcast). 
to people's ideological awareness. The Mora dialogue also demonstrated that plesetan has not declined in popularity since the New Order, but found a new place among other, more 'transparent' journalistic devices to talk about politics and society.

Unlike the consoler-therapist host, other hosts of Indonesian radio talk shows do not necessarily aim at making their conversation partners feel at ease or giving them enough opportunity to talk. They belong to the category of 'star' or 'hero' hosts, who often present themselves as experts in a particular field and behave in an authoritarian way. While their attitude is partly meant to create an image and sell their own name and the name of the radio station, it sometimes also serves to set an example of critical thinking and to train the listener-participants to formulate their own opinions coherently and concisely.

An example of a star-hero trying to achieve both goals is Ratna Sarumpaet, a well-known Indonesian actress, playwright, stage-director and human rights activist, who is also presenter of the Jakarta News FM talk show 'Sabtu bersama Ratna' ('Saturday with Ratna'). The title of the show immediately confirms the star-status of the host, as the sheer mentioning of her name is thought to attract listeners and provide the programme with authority in the same way as the names of popular international television talk show hosts such as Oprah Winfrey do. Sarumpaet's star-status is confirmed by the presentational style and rhetorical devices she uses in her discussions with listeners and other conversation partners.

At the start of the 20 October 2001 broadcast of the talk show, for instance, Sarumpaet presented herself as a star by making no secret of the fact she had overslept and arrived too late in the studio. With no signs of any shame either, she asked her male co-host what the topic was they were going to talk about with the listeners. The topic of the day happened to be the attitude of the police towards demonstrators and journalists during the Front Pembela Islam (FPI, Cadre of Defenders of Islam) demonstration against the US invasion in Afghanistan on Israk Mikraj, 15 October 2001. ${ }^{11}$ In spite of her real or pretended lack of preparation, Sarumpaet was able to give an impressive monologue of about ten minutes on the war in Afghanistan, the standpoint of the Indonesian government, and the attitude of the police during the FPI demonstration. After this monologue, listeners had the opportunity to phone

11 Israk Mikraj, which is always on the 27th of Rajab (the seventh month of the Islamic calendar), commemorates the Prophet Mohammad's flight on a winged horse known as a Buraq from Mecca to Jerusalem. During the flight, Mohammad went through the seven levels of heaven, where he met several earlier prophets of Islam. The Prophet's trip instigated the Islamic rule of the five daily prayers. 
in and give their opinions, although both they and the timid co-host of the programme were regularly overpowered by Sarumpaet's rhetorical skills and confidence.

According to Sarumpaet, President Megawati had to have courage to present an independent Indonesian viewpoint about the war in Afghanistan during the Asia-Pacific Economic Cooperation (APEC) meeting she was going to attend in Shanghai. Although Sarumpaet condemned the terrorist attacks in the United States on 11 September 2001, she thought Osama Bin Laden and his companions could only be accused after independent investigation had produced legal evidence for their involvement. This investigation had to be conducted by the United Nations, where Sarumpaet, in one of her self-confirming statements, confessed to have 'some good friends' herself. She could also not accept that a country was bombed and civilians killed because of the search for one man. She predicted that the war would create new antipathy to the United States, also outside the Muslim world, and hoped that Megawati would represent her views and feelings during the APEC meeting.

Sarumpaet condemned the behaviour of the police during the FPI demonstration as 'overacting' (she used the English expression). She did not accept the excuse that the policemen who were on duty were tired and had not had a proper meal, as she thought it was the police force's own responsibility to have their men well-prepared for a particular task. According to Sarumpaet, the police were wrong in hitting the demonstrators, and should have used water-cannons instead.

At one point during the interactive discussions Sarumpaet was confronted with an equally stubborn listener-participant with a different opinion. The listener believed that the police had the right to act harshly against FPI, as they behaved against the law by organizing a demonstration on a public holiday, abused the name of Islam and were violent. He also argued there was sufficient reason for an attack on Afghanistan, as the Taliban regime was not only reluctant to co-operate in capturing Osama Bin Laden, but also involved in the repression of their fellow-countrymen.

Unlike other talk shows in which hosts tend to easily agree with their conversation partners, Sarumpaet used her star-status and authority as a host to fully attack the listener's arguments, to repeatedly interrupt him, and eventually even to close off the discussion, as she thought their differences of opinion were unbridgeable. Paradoxically, Sarumpaet was convinced that her rather authoritarian behaviour would teach the listeners the laws of democracy.

Sarumpaet (S): Do you have the evidence or not [that Osama Bin Laden was the mastermind behind 9/11], that is what I ask.

Listener (L): Yes, there is evidence. 
S: What!? It has not been announced. Are you a policeman or something?

L: It is the evidence that has been issued by the American government.

$S$ [ironically]: Sir, you have an obligation [to spread the information], so that the demonstrations will subside. Please prove it. Where did you get it from?

L: It is on the BBC.com website, Madam.

S: What, Sir. I have also read it, that's not evidence. [cynical laughter] Come on. That's supposition, supposition is different from evidence, Sir.

Co-host [without irony]: Based on intelligence data. This man really knows what intelligence is.

S: Intelligence, that is the intelligence of America, whose objectivity as a victim is very much in doubt. So what, Sir?

L: For us it is always like that. In the case of Suharto, we demanded that Suharto would be brought to justice. Then the court said there was no evidence, but we said that the facts were there. Well, in fact, if we want to talk about evidence of which the validity really has to be proven, it has to be in court. Osama has to appear. I only want to see that...

S: Sir, Sir, also, er... you really have a 'bias' [in English]. We were just discussing Afghanistan. I want to return to Afghanistan. I want to pretend that I agree with you. You said there was evidence. Alright, let there be evidence. Now in that process of going to war in Afghanistan, the matter was to capture Osama.

$\mathrm{L}$ : That is correct.

S: According to your sound reason, does one have to kill people and destroy a country in order to capture Osama? That is what I want to ask. That is what I want to ask, you have not answered me yet. You haven't answered me yet. Is it logical or not that Osama can be captured with staging a devastating war in Afghanistan, in which buildings are destroyed and everything becomes as flat as the soil. Will one get Osama or not?

L: It's possible. The answer is that it can be done.

S: Are you prepared to sacrifice so many people!? Apparently you are higher than God.

L: No. It is because the Taliban regime does not want to cooperate in releasing Osama, who is sacrificing his own people.

S: Oh my, at moments like this democracy becomes painful. I have to debate with aversion, with a person who apparently also does not want to open his mind to accept other people's thoughts. So I want to apologize, Sir. I am really not an authoritarian ruler, but as I see that our discussion has no purpose any longer, I apologize, I will end the discussion with you.

Co-host: Okay, that is maybe one of the dynamics of democracy, that a debate like this takes place.

S: Yes, but in democracy, we learn, listeners, and we learn to understand. I persisted all the time and did not use any... How many of my question remained unanswered? Yes, that is democracy. If you ask questions there have to be answers, alright. Come on. ${ }^{12}$

12 Sarumpaet (S): Bapak punya nggak bukti ya, saya tanya.

Listener (L): Ya, udah ada.

S: Masak!? Tidak diumumkan. Apakah Bapak ini pulisi atau apa ini? 
Although both programmes were on the same topic, the heated ambience in this edition of 'Sabtu bersama Ratna' presents a sharp contrast with the relaxed and humorous atmosphere in the 'Mora interaktif' talk show discussed earlier. Unlike the 'Mora interaktif' show, Sarumpaet's programme does provide an institutionalized forum for critical-rational debate about national and international political affairs. The accessibility of this public forum is questionable, though, due to the controlling power and authoritarian behaviour of the host. While Sarumpaet's show may enhance the ideological awareness of the public by providing a model for critical thinking, its dialogical quality in a narrow sense is restricted, as the host performs a role as the self-nominated representative rather than the 'presenter' of the public.

L: Bukti yang udah dikeluarkan oleh pemerintah Amerika.

S: Pak, Bapak punya kewajiban lho supaya reda ini demonstrasi. Coba buktikan. Bapak diterima dari mana itu atuh?

L: Di website BBC.com itu sudah ada, Bu.

S: Apa, Pak. Itu juga sudah saya baca, itu bukan bukti. Hehehe. Bagaimana. Itu sangkaan, sangkaan berbeda dengan bukti, Pak.

Co-host: Berdasarkan data intelijen, Bapak tahu persis kalau yang namanya intelijen.

S: Intelijen, itu intelijen Amerika yang obyektivitasnya sebagai korban sangat diragukan. Bapak bagaimana sih, jadi?

L: Kita selalu kaya gitu. Kalau dalam kasus Suharto kita menuntut Suharto itu diadili, terus pengadilan bilang nggak ada bukti, tapi kita bilang, ini lho fakta-faktanya. Nah, sebetulnya kalau mau kita bicarakan bukti harus benar-benar dibuktikan, itu harus di pengadilan. Osama harus muncul. Cuma saya mau lihat...

S: Pak, bapak, juga apa ya... Bapak ini 'bias' gitu lho. Tadi kita bicarakan Afghanistan. Saya mau kembalikan ke Afghanistan. Saya mau seolah-olah menyetujui Bapak. Bapak mengatakan sudah ada bukti. Ok, sudah ada bukti. Sekarang dalam proses peperangan ke Afghanistan itu, urusannya berarti mau menangkap Osama.

L: Betul.

S: Menurut akal sehat Bapak, apakah menangkap Osama harus membunuhi orang dan menghancurkan satu negeri? Saya mau tanya. Saya mau tanya, Bapak belum jawab saya. Bapak belum jawab saya. Secara logika, bisa nggak tertangkap Osama dengan memerangi Afghanistan habishabisan, gedung hancur, rata sampai tanah semuanya. Dapat nggak Osama?

L: Bisa. Jawabannya, bisa itu dilakukan.

S: Bapak rela mengorbankan begitu banyak manusia!? Bapak lebih dari Tuhan kayaknya.

L: Bukan. Karena rezim Taliban tidak mau bekerja sama untuk melepaskan Osama itu yang mengorbankan rakyatnya sendiri.

S: Aduh, ini, di sinilah saat-saatnya demokrasi jadi menyakitkan. Saya harus berdebat dengan ogah, orang yang juga ternyata tidak mau membuka akalnya untuk menerima pikiran orang lain. Jadi saya minta maaf Bapak ya, saya memang bukan penguasa yang otoriter, tetapi karena saya lihat diskusi kita sudah tidak berguna, saya minta maaf, saya hentikan pembicaraan dengan Bapak. Co-host: Ok, salah satu dinamika dari demokrasi mungkin ya, munculnya perdebatan seperti ini. S: Ya, tetapi, demokrasi, kita belajar, pendengar, dan belajar memahami. Saya terus-menerus ngotot aja dan tidak menggunakan... Berapa pertanyaan saya nggak terjawab? Ya, itulah demokrasi. Bertanya harus ada jawabannya dong, bagaimana ini (Jurriëns, transcription of a 20-10-2001 broadcast). 


\section{The authority of experts}

In talk shows, hosts usually talk not only with lay listeners, but also with specialists who are invited to the studio or interviewed by phone in order to give their expert comments on a particular topic. They are called narasumber ('informants'), pengamat ('observers') or pakar ('experts'). The experts are supposed to give in-depth information or alternative views on topical issues, and to give authority to and underline the seriousness of the programme in which they participate. This is illustrated by SCFM's jingle for the programme 'Dunia bisnis Indonesia' ('Indonesian business world'), in which the Surabaya-based commercial station attempts to convince the audience of the usefulness of its programme by announcing the presence of 'competent experts, including observers and even practitioners from the business world'. ${ }^{13}$

In their analysis of American and British television talk shows such as Oprah, Donahue and Kilroy, Livingstone and Lunt (1994:62) observe that the expert is 'cast at times in the role of villain'. The position of experts becomes undermined when they have no opportunity to present a coherent story based on scientific evidence, but are forced to simplify their argument and merely rely on their status as a reliable information source. Lay participants often become the 'real' experts in talk shows, as the host and the other audience members validate their accounts as authentic, based on real-life experience (Livingstone and Lunt 1994:98-9).

The Indonesian radio talk shows I recorded in 2001 and 2002 provided a different picture. While listener-participants often undermined each other's authority and sometimes the authority of the host, independent experts were usually held in high esteem. The special position of the expert partly reflects an admiration for educational or professional achievement and partly a strong sense of hierarchy in Indonesian society. An example is the 19 October 2001 broadcast of Trijaya's one-hour interactive talk show 'Thank God it's Friday', in which a host respected and emphasized the status of an invited expert by referring constantly to his academic titles. In the broadcast two male hosts discussed with several expert informants (called nara sumber) and the audience the health effects of anthrax, the poisonous white powder spread by mail in the aftermath of the US invasion in Afghanistan.

In their first interview, one of the hosts talked with Professor Doctor Umar Fahmi, a specialist in the field of contagious diseases from the Indonesian Department of Health. Fahmi discussed the origins, characteristics and effects of anthrax from a medical viewpoint. He explained that anthrax was a bacterial disease, not a virus, and that its natural, non-chemical variant could 
be found in several rural areas in Indonesia. Fahmi's authority as a specialist was confirmed by the host, who frequently addressed him as 'Prof' or 'Doc'.

Host $(\mathrm{H})$ : Prof Umar Fahmi, er... isn't it true there is actually also anthrax in Indonesia, as the lands also er... contain many of those spores.

Fahmi (F): Yes, but not every region.

$\mathrm{H}$ : Not every region. Okay...

F: There are certain regions, which have actually already been mapped. And there we have prohibitions against... we recommend that people do not keep livestock. $\mathrm{H}$ : Where is that, Prof er, Prof?

F: For example, there are eleven provinces. For instance, in the regions of West Java, Central Java and West Sumatra. But not in the whole of Sumatra, not in the whole of West Sumatra. For instance, there are several places. Further, in the Eastern Lesser Sunda Islands and so on. There are several places, there are eleven provinces.

$\mathrm{H}$ : What are the initial symptoms, so that it can be anticipated, Doc?

[...]

H: In Indonesia, how many cases... But there have not appeared any, have there, Prof, for how long...?

F: Last year there was one, exactly during the Pilgrimage season. When the Pilgrimage started, there were several people who died indeed. But there were dozens of people who got infected.

H: How many cases per year, Prof?

F: Oh, I have forgotten. I have already... forgotten how many, but...

H: It was not significant, was it?

F: There were dozens, dozens even.

$\mathrm{H}$ : That was because of the anthrax bacteria, wasn't it, Prof?

$[\ldots] .^{14}$

14 Host (H): Prof Umar Fahmi, ini er... di Indonesia sebenarnya juga ada anthrax ya, karena juga tanah-tanah juga er... banyak mengandung spora itu ya.

Fahmi (F): Ya, tapi tidak semua wilayah.

H: Tidak semua wilayah. Ok...

F: Ada beberapa wilayah-wilayah tertentu yang petanya sudah ada sebetulnya. Dan di situ itu kita melarang supaya... menganjurkan supaya tidak beternak begitu.

H: Di mana itu, Prof er... Prof?

F: Sebagai contoh, itu ada sebelas propinsi ya. Misalnya di daerah Jawa Barat, Jawa Tengah, Sumatra Barat. Tapi tidak seluruh Sumatra itu, nggak seluruh Sumatra Barat, misalnya ada beberapa tempat gitu. Lalu di Nusatenggara Timur dan sebagainya gitu. Ada beberapa tempat, ada sebelas propinsi.

H: Gejala awalnya supaya bisa diantisipasi gitu bagaimana, Doc?

$[\ldots]$

H: Kalau di Indonesia, kasusnya itu seberapa... Tapi tidak ada yang menonjol ya, Prof, selama...?

F: Tahun lalu kan, pas musim Haji itu. Mau Haji kan, ada beberapa yang meninggal memang.

Tapi ada puluhan yang kena.

H: Berapa kasus, Prof, per tahun?

F: Aduh, lupa. Saya sudah... Lupa saya berapa ya, tapi... 
The next interview was with Juanda, a military analyst and former marine colonel. Juanda explained that terrorists in the Arab world or the United States had probably stolen the technology for producing anthrax from official US institutions. After Juanda, the Trijaya gatekeepers broadcast a response from one of the listeners, who provided follow-up information on Fahmi's talk and presented himself as an expert without specifying his professional background.

Some experts have been invited to give their opinion in radio or television talk shows so often that they have become real media personalities or stars, and sometimes even become involved in media activities that are only loosely or not at all related to their field of expertise. Famous names among them are Andi Mallarangeng, Denny J.A., Dewi Fortuna Anwar, Didik J. Rachbini, Emil Salim, Faizal Basri, Harkristuti Harkrisnowo, Imam B. Prasodjo, J. Kristiadi, Kastorius Sinaga, Kusnanto Anggoro, Rizal Mallarangeng, Sjahrir and Sri Mulyani. The majority of these people hold highly esteemed university degrees from the United States, Europe or Australia, and work as lecturers or researchers at Indonesian universities or national or international research institutes. ${ }^{15}$ In general, they regard their participation in talk shows as a social obligation, as a means to share academic or professional knowledge with society at large.

For some experts talk shows have also become an important income source, as the money for one media appearance sometimes exceeds their normal monthly salary. Others refuse any financial gifts or are unwilling to participate in debates that go beyond their field of expertise. Some fear that public appearances in media debates may corrupt their academic or professional integrity. In Habermasian terms, these experts do not so much fear a refeudalization of society as the refeudalization by society of their own discipline. Andi Mallarangeng, a sociologist with a doctor's degree from Northern Illinois University, admitted that it was sometimes difficult for experts to find a balance between their academic or professional activities and their public appearances. ${ }^{16}$ Mallarangeng himself used to be the host of the talk show 'Interupsi' ('Interruption') on the commercial television channel Rajawali Citra Televisi Indonesia (RCTI). He also regularly appeared as invited expert in many other television and radio talk shows before he became President Susilo Bambang Yudhoyono's official spokesperson.

The producers of radio or television talk shows have there own criteria

\footnotetext{
H: Tidak signifikan ya.

F: Ada sepuluhan, sepuluhan malah.

H: Itu karena bakteri anthrax ya, Prof?

[...] (Jurriëns, transcription of a 19-10-2001 broadcast).

15 'Cendekiawan, televisi, salon kecantikan', Kompas (14-10-2001):13.

16 'Cendekiawan, televisi, salon kecantikan', Kompas (14-10-2001):13.
} 
for selecting experts. According to Billy Soemawisastra, special programme manager of the commercial television station SCTV, the invited specialists should not reduce the attractiveness of a talk show.

Imagine that the person who appears on television is an informant who is maybe really clever, but stammers when he speaks. Or someone who cannot speak 'to the point' [in English]. The talk show will certainly not be interesting if the informant is not active. For example, if he does not speak if he is not asked a question, or if he only utters brief answers to questions. ${ }^{17}$

If media appearance rather than expertise becomes the main criterion for inviting specialists, the danger of the aestheticization of politics (Benjamin 1977:42) lurks, as rational debate in the public interest is compromised by commercial or ideological interests. Other producers agree that some experts are mere tokens of authority in talk shows, as they 'rarely read' (jarang membaca), have a 'weak theoretical framework' (kerangka teorinya lemah) and 'just talk for the sake of talking' (asal bicara). ${ }^{18}$ Some producers refuse to hire a well-known expert as a programme host, as they fear that the expert's background or reputation as a highly opinionated person may clash with the host's preferred role as an objective debate moderator, and deter other potential participants from interacting in dialogue. ${ }^{19}$

\section{Editors and gatekeepers}

As they rely on a rich variety of information sources including their own listeners and national and international news agencies, Indonesian radio stations with a long experience in news production such as Trijaya, Suara Surabaya and Mara try to maintain a high quality team of editors and gatekeepers, who verify incoming information before it is transmitted to listeners. The gatekeepers also regulate phone calls from listeners and decide whether they will be provided with or denied access to a talk show or news bulletin. This means they bear responsibility for the extent to which the listener-participants allowed entry are representative of larger groups in society. The editors decide on the structure of the programme as a whole by selecting news items and interviews, and adding commercials, music, jingles and sound effects.

Suara Surabaya keeps its own database with the names, addresses and discussion topics of all the listeners that have ever contributed to their interactive programmes. In 2002, the database contained information about at 
least 40,000 people. It provides the radio station's crew with an archive of discussion topics, a means to deny access to callers who misbehaved during talk shows and a source for general reflection on the discursive behaviour of hosts and listeners. Suara Surabaya's gatekeeper team allows listeners to participate in programmes only after their personal data and aims for participation have been identified and compared with or added to the information in their computer archive (Suara Surabaya 2002). While this restricts Suara Surabaya's accessibility, or its publicness in a narrow sense, it may enhance the chances of rational debate taking place and consensus being reached as in the bourgeois public sphere.

Usually the gatekeepers will report the information from listeners 'live' in a special information section of their current affairs programme package 'Kelana kota' ('Wandering around the city'), but sometimes the listenerparticipants themselves are allowed to have short on-air dialogues with the programme hosts. The following two transcripts from a 23 July 2002 'Kelana kota' 5-6 p.m. section on police information and traffic jams illustrate the two possibilities. The first possibility of reported speech or indirect dialogue is represented by a gatekeeper (Ema) reporting the successful conclusion of a case in which the Surabaya police (represented by Armin Ismail) had requested Suara Surabaya to broadcast information on a missing person (the daughter of Ms Pipud) in order to help finding her.

Gatekeeper Ema: Ms Pipud earlier reported to the local police headquarters in Surabaya. Then Mr Armin Ismail informed Suara Surabaya that Ms Pipud had lost her daughter. Her daughter is indeed 17 years old, but there was much concern because of her mental disability. It turned out that she was found in the North Surabaya area at 5 p.m., now she has been brought to her grandmother in the Sidotopo area. 'Thanks to Suara Surabaya' [Ema representing the words of Ms Pipud].

Female host: Fine. Congratulations, madam. You have already found your daughter. Thank God. Our only help was the mere provision of information. ${ }^{20}$

The second possibility of direct dialogue is represented by a section in which a listener (Stanley) provided the host (Restu) with information on a traffic accident he witnessed from his car.

20 Gatekeeper Ema: Ibu Pipud tadi kan lapor ke Polwil Mabes Surabaya, kemudian Pak Armin Ismail yang menyampaikan ke Suara Surabaya kalau Ibu Pipud kehilangan putrinya ya. Kalau usianya memang sudah 17 tahun, tapi karena ada cacat mental, jadi sempat sangat khawatir. Tadi pukul 5 ternyata ditemukan di kawasan Surabaya Utara ya, sekarang dibawa ke neneknya di kawasan Sidotopo. 'Terima kasih untuk Suara Surabaya.' Female host: Baik. Selamat juga, Bu. Sudah ketemu putrinya. Alhamdulillah juga. Kita bantunya cuma hanya sekedar informasi (Jurriëns, transcription of a 23-6-2002 broadcast). 
$[\ldots]$

Host Restu $(\mathrm{H})$ : A Panther [the make of a car] went into a ravine and a truck is blocking [the road]?

Listener Stanley (L): It is almost blocking [the road]. (H: Almost blocking...).

$\mathrm{H}$ : But do you think it is possible to pass it or not, Sir, for [cars]...

L: Yes, for one car only.

$\mathrm{H}$ : For one car only, that should be enough.

L: On one traffic lane it is definitely possible, I have just passed it. $(\mathrm{H}$ : Oh, that's good...). There is still a traffic jam in the middle of the road. The traffic is proceeding slowly. (H: Alright...). Please be patient, friends, be careful.

$\mathrm{H}$ : Obviously, there is already an official, Sir?

L: Yes, there is. I... I can just see there is a police officer... Two police officers. One of them is on a motorcycle. He has begun 'calling' [in English], perhaps another police officer.

H: Fine. Thank you.

S: Who did I speak with?

H: I'm Restu, Mr Stanley.

S: Oh Ms Restu, thank you.

H: You're welcome, Sir. Have a safe drive. ${ }^{21}$

Apart from storing information on their listener-participants, Suara Surabaya also attempts to build a publicly accessible audio-archive with programme recordings on its Internet website. According to Suara Surabaya's programme manager Errol Jonathans (2000:56-7), the archive was an expression of Suara Surabaya's awareness that past and current developments steer the future and can regain topical value at any moment. He regretted, however, that archiving was still one of the weakest points in Indonesian radio journalism due to a lack of journalistic training or interest as well as a lack of economic means.

One section of Suara Surabaya's audio-archive contains statements of

$21 \quad[\ldots]$

Host Restu (H): Panthernya masuk jurang, truk melintang ya?

Listener Pak Stanley (L): Hampir melintang. (H: Hampir Melintang...).

H: Tapi kira-kira bisa nggak, Pak, lewat untuk...

L: Ya, satu mobil aja.

H: Satu mobil aja, cukup ya.

L: Satu jalur pasti, saya barusan lewat. (H: Oh, baik...). Di garis tengah itu masih ada mojoknya.

Maju sedikit. Teman-teman bersabar aja, hati-hati.

$\mathrm{H}$ : Yang jelas sudah ada petugas ya, Pak?

L: Udah ada. Saya... ada Bapak polisi saya lihat pas... Dua polisi. Satu pakai sepeda motor. Dia udah mulai 'calling' mungkin yang lain.

H: Baik ya. Terima kasih.

S: Dengan siapa ini?

H: Saya Restu, Pak Stanley.

S: Oh Mbak Restu, terima kasih.

H: Sama-sama Bapak. Selamat meluncur (Jurriëns, transcription of a 23-6-2002 broadcast). 
government representatives and other high officials. ${ }^{22}$ This section serves journalism's Fourth Branch function of monitoring government, parliament and the judiciary system, as it is specifically meant to assist Suara Surabaya listeners in holding high officials publicly accountable for the promises they make. According to Jonathans, while officials can easily distance themselves from written reports of their statements by denouncing them as misquotations or misinterpretations, audio-recordings make it much more difficult for them to deny responsibility, even if sound-bites can also be edited. ${ }^{23}$ Jonathans responds here to a journalistic and social convention in Indonesia and the West that the spoken word bears a higher degree of authenticity and evidence than the printed word.

While Indonesian editors and gatekeepers usually provide their radio station with an image of neutrality and objectivity, and attempt not to alienate the audience or cause any conflicts in society, some radio stations are not afraid to join public debates with subjective or provocative statements. Radio $68 \mathrm{H}$, which is affiliated to $\mathrm{KBR} 68 \mathrm{H}$, is an example of a radio station that gives its editors the space to express their opinions in special on-air editorials, called 'Sikap redaksi Radio Berita 68H' ('The attitude of Radio Berita 68H's editorial board'). For instance, in the 14 August 2002 edition of the editorial, the editors did not shy away from criticizing the Accountability Report (Laporan Pertanggungjawaban) of the controversial governor of Jakarta, Sutiyoso. The report had been accepted by the regional government of Jakarta on 13 August 2002, which meant that Sutiyoso could announce his candidacy for a second term as governor of Jakarta.

The Radio $68 \mathrm{H}$ editors regretted that the demands of thousands of people demonstrating against the report had been neglected by the main political parties. The protesters claimed that Sutiyoso had failed during his first term as governor, and that he had bribed politicians in order to have his Accountability Report approved. In order to have their bribery allegations proven, they urged the Komisi Penyelidik Kekayaan Pejabat Negara (KPKPN, Commission of Investigators of State Officials' Wealth) to reinvestigate the wealth of Sutiyoso as well as the members of the regional parliament. They thought there were strong grounds for such an investigation, as many political factions that were initially sceptical about the Accountability Report eventually had no problems with approving it. After representing the views of the protesters against the report, the Radio $68 \mathrm{H}$ editors concluded the editorial with their own negative commentary on Sutiyoso's performance.

22 http://www.suarasurabaya.net (accessed 24-7-2002).

23 Errol Jonathans, personal communication, Surabaya, 24-7-2002. 
Isn't it strange that Sutiyoso's completely unsatisfying performance can be accepted by the majority of the council members? This is a dishonesty that has to be questioned by all the citizens of Jakarta. The bribing rumours would not have appeared if Sutiyoso had indeed shown an admirable performance during the five years that he led Jakarta. But everyone knows that, unlike the mayor of New York who immediately took action after the WTC buildings were destroyed, Sutiyoso even seemed to panic when Jakarta was hit by floods. During the five years that he led the capital, the citizens of Jakarta never enjoyed safe public transport, the traffic was chaotic, the city infrastructure disorganized, crime flared up everywhere. In spite of this series of dark results, the majority of the members of the Regional Parliament of the Special Capital District of Jakarta accepted Sutiyoso's Accountability Report. While he also has a number of human rights abuse records, there is a possibility that the citizens of Jakarta will still have to be led by the same person. ${ }^{24}$

Editorials such as Radio 68H's do not involve direct audience participation, but aim at initiating a broader dialogue and making the public think about public affairs by setting an example of rational-critical argument. The editorials confirm that Indonesian radio journalists in post-Suharto Indonesia do not necessarily seek refuge in a stripped-off type of peace journalism and avoid talking or writing about sensitive social issues, but also attempt to adhere to the Fourth Estate journalistic principle, which in accordance with the alleged spirit of Reformasi, secures the watchdog function of the media and its independence.

24 Betapa tidak aneh kalau kinerja Sutiyoso yang sama sekali tidak memuaskan bisa diterima mayoritas anggota Dewan? Inilah ketidakwajaran yang harus dipertanyakan seluruh warga Jakarta. Isu suap tidak akan muncul kalau memang Sutiyoso menunjukkan performa yang mengagumkan selama lima tahun memimpin Jakarta. Tetapi semua tahu, tak seperti walikota New York yang langsung turun begitu gedung WTC dihancurkan, Sutiyoso bahkan nampak panik ketika Jakarta diterjang banjir. Selama lima tahun memimpin Ibu Kota, warga Jakarta belum pernah menikmati nyamannya angkutan publik, lalu lintas semrawut, tata kota amburadul, kejahatan marak di mana-mana. Dengan sederet prestasi buram itu, mayoritas anggota DPRDDKI Jakarta menerima Laporan Pertanggunjawaban Sutiyoso. Dengan sejumlah cacatan pelanggaran HAM yang ia miliki, warga Jakarta kemungkinan masih harus dipimpin orang yang sama (Jurriëns, transcription of a 14-8-2002 broadcast). 


\section{Chapter vi}

\section{The activity of interactive radio journalism}

Having explored the genre of the interactive talk show and its actors, in this chapter I will analyse the 'activity' of interactivity, or the impact of the genre and its actors on society. I distinguish three roughly divided fields of Indonesian public life on which interactive radio has had its impact: public discourse, social action and identity-formation. In the field of discourse, it has created specific types of journalism and media literacy. In terms of social action, it has stimulated people to organize themselves and develop communal activities. With regard to identity, it has contributed to people's regional awareness and sense of citizenship.

An example of a discursive effect of Indonesian interactive radio is the genre of 'multi-sided journalism', used by radio stations to provide different perspectives on the 'same' event. Stations do not necessarily need interactive programmes to create multi-sidedness, as monologic reportage or documentary-type programmes can also provide multiple perspectives. However, the type of interactivity that will be discussed not only serves multi-sidedness as such, but is also meant to make the audience aware of and learn from the dynamics of debate. I will analyse a talk show produced by Trijaya, which, rather than representing different perspectives in a monologic narrative, allows different parties with different opinions to speak for themselves. By providing each party with equal opportunity to speak, Trijaya attempts to set a model for democratic debate in Indonesian society.

The case-studies of Suara Surabaya and Jakarta News FM will illustrate that Indonesian radio talk shows also initiate concrete social action. In Suara Surabaya shows, listeners talk about and provide practical solutions to social problems such as traffic jams and burglary. Jakarta News FM broadcasts are used for organizing humanitarian off-air activities such as the building of schools for poor village communities.

In terms of identity creation, I argue that the discussion of local issues and the use of regional languages in Indonesian interactive radio have the potential to provide listeners with a sense of citizenship and strengthen their regional awareness. However, interactive radio can sometimes also lead to 
regional chauvinism or narrow patriotism, as demonstrated by media representations of ajeg Bali ('firm Bali'), and does not necessarily imply publicness or confirm citizenship, as demonstrated by radio station Mora. While Mora presents itself as a public medium that provides legal advice to its listeners, it also represents the business interests of its owner's legal office. This conflict of interest can be seen as a symptom of the Indonesian public sphere being refeudalized in a Habermasian sense.

Indonesian media institutions have recognized and attempted to reduce the risk of this type of refeudalization by developing interactive talk shows aimed at enhancing the media literacy of their audiences. This type of talk show, which is dialogic in a Bakhtinian sense, is another example of how Indonesian talk-back radio affects public discourse and possibly also social action and identity formation. In this chapter, I will analyse a programme produced by Suara Surabaya in co-operation with Lembaga Konsumen Media, in which hosts, experts and listeners discuss the impact of the media on Indonesian society. In the following chapter, I will focus on Global FM's efforts to promote media literacy among its crew and listeners.

\section{Multi-sided journalism}

A journalistic genre that has come into being as a discursive effect or subgenre of Indonesian interactive radio is multi-sided journalism. The commercial radio station Trijaya in Jakarta, which has a long and respected reputation as the organizer of debates on the Indonesian airwaves, has been one of the pioneers of this genre. Already during the New Order, Trijaya had interactive talk shows on topical affairs, including sensitive political issues. Ironically, the station had more opportunities to address such issues than many other Indonesian media because of its protected status as part of the Bimantara business group, owned by President Suharto's second son Bambang Trihatmojo. ${ }^{1}$

As mentioned before, Trijaya Jakarta profiles itself as a news station, using the slogan 'More than just music'. In 2001, Trijaya Jakarta's news programmes included 'Lintas informasi' (a news bulletin, broadcast once an hour daily), 'Trijaya market report' (information from the Jakarta Stock Market, broadcast from Monday until Friday at 10 a.m., and 1:45 and 4:45 p.m.), 'Trijaya economic business' (national and international business reports, broadcast from Monday until Friday at noon), 'Seputar Indonesia di Trijaya FM' (relays of RCTI's news bulletin 'Seputar Indonesia' or 'Around Indonesia', broad-

1 Samuel 2002:310; Sen 2003:580-2. See Chapter III for a description of Bimantara's network of radio stations in Jakarta and other places in Indonesia. The business group also owns the commercial television station RCTI, which is located at the same media complex as Trijaya Jakarta. 
cast from Monday until Saturday at 6:30 p.m.), and 'Trijaya news round-up' (an overview and analysis of the news of the day or the previous day, from Monday until Friday at 6 p.m. and 6 a.m.).

In 2001, Trijaya Jakarta's talk shows on current affairs included 'Indonesia first channel', 'Jakarta first channel' and 'Thank God it's Friday'. 'Indonesia first channel' contained discussions about topical issues and was broadcast on Monday from 7:30 until 9:30 a.m. 'Thank God it's Friday' dealt with social problems and public services and was broadcast on Friday from 7 until 9 a.m. 'Jakarta first channel' invited journalists and experts to analyse the main news items in the morning newspapers and was broadcast on Tuesday, Wednesday and Thursday from 6 until 9 a.m.

According to Trijaya Jakarta's former news programme director, Ido Seno, Trijaya has tried to implement the idea of multi-sided journalism in its talk shows by giving different parties equal opportunity to express their own viewpoints. ${ }^{2}$ This multi-sided journalism has functioned as a provocative and productive answer to New Order's one-sided or monologic, non-negotiable representation of social and political reality. The radio station does not present itself as the provider of 'independent' news, as this would hide the fact that news is always biased to a certain extent. Multi-sided journalism, on the other hand, makes listeners media-literate by providing them with different insights into an event and thus training them to put the 'factuality' of news and information into perspective.

I will analyse how multi-sided journalism works in Trijaya's 'Jakarta first channel', a morning show on current affairs presented by a host and one or more interviewers. The first part of 'Jakarta first channel' consists of the host reading the headlines and leading articles of the major national newspapers, such as Kompas, Koran Tempo and Media Indonesia. It also includes Trijaya's own news bulletin 'Trijaya news round-up', music and commercials. The second part of the programme consists of a talk show in which the interviewers talk with invited informants or experts (nara sumber) on a topical issue.

In accordance with the principle of multi-sided journalism, the invited guests in the talk show are usually representatives of different professions or interest groups, providing the listeners with different interpretations of the 'same' topic. The listeners do not always have the opportunity to phone in and give their opinion, as Trijaya prefers to have an organized debate in which spokespersons or representatives of different sections of society are given an equal opportunity to speak. ${ }^{3}$ In this sense, 'Jakarta first channel' follows the rules of the classical debate in which rational discussion takes place in an orderly manner under the guidance of a chair. This type of debate belongs to 
the Habermasian bourgeois public sphere rather than the oppositional public sphere. The literal dialogism of 'Jakarta first channel' is restricted, similar to the Indonesia Media Law and Policy Centre (IMLPC) programmes discussed earlier. However, unlike the IMLPC programmes, Trijaya's talk show is not pre-recorded and does represent a certain dynamic atmosphere, with the unpredictable directions and outcomes of live interaction.

An example of a 'Jakarta first channel' edition with a meta-journalistic character, discussing the role of the media in Indonesian society, was broadcast on 16 October 2001. This edition was about the same 15 October 2001 demonstration against the US invasion in Afghanistan discussed in relation to the talk show 'Sabtu bersama Ratna'. The demonstration was organized by the Indonesian fundamentalist Islamic organization Front Pembela Islam (FPI) in front of the Indonesian parliament building in Jakarta. The police had attempted to disperse the demonstrators, as demonstrations on public holidays were prohibited according to article 9 of the 1998 Undang-Undang Menyampaikan Pendapat di Muka Umum or 'Law on the Expression of Opinion in Public', which was meant to accommodate Reformasi ideals such as the right to organize demonstrations.

When the FPI members refused to stop the demonstration and leave the location, a short violent confrontation between the police and the demonstrators broke out. Several people got wounded, including reporters from commercial television stations (Metro TV, Indosiar) and the written press. The police also confiscated the reporters' films and video-cassettes that contained images of the confrontation. Media institutions were outraged that some of their reporters were wounded and journalistic material was confiscated, and this provided the incident with only more press coverage, including reports and discussions in radio programmes such as Trijaya's 'Jakarta first channel'. In the 16 October broadcast of 'Jakarta first channel', two male interviewers talked with a representative from each of the major parties involved in the conflict: FPI, the police, and the press. The interviews were conducted by phone and took about fifteen minutes each.

The first interview was with Habib Risieq Shihab, chairman of FPI. Shihab declared that FPI would take three steps in the aftermath of the incidents: 1. They would not let themselves be 'provoked' (diprovokasi) and would 'restrain themselves' (menahan diri) from taking violent revenge on the police or other groups in society, 2. They would continue searching for FPI members who were still missing, and 3. They would hire lawyers and take legal action against the police, so that 'the supremacy of the law would be upheld' (supremasi hukum ditegakkan). According to Shihab, FPI had sent a letter to the police to announce their plan to hold a demonstration on 15 October, but never received any answer in return forbidding them to organize demonstrations on public holidays. Shihab suspected that the police attempted to put FPI in 
a bad light, in order to distract attention from the US invasion in Afghanistan and prevent other groups from organizing demonstrations. FPI itself pleaded for the discontinuation of diplomatic relations between Indonesia and the United States.

The second interview was with superintendent Anton Bachrul Alam from the Jakarta regional Metro Jaya police. Alam explained that the video cassettes and films from the television and newspaper reporters were found and would be returned. He apologized for the police conduct, emphasized the importance of the work of journalists, and would undertake an investigation into the police officers who should be held responsible for the incident. The police would also help with searching for the missing FPI members. According to Alam, the police had replied FPI's letter, asking for more details on the planned demonstration, but never received any further information in return. The police expected violence to occur from the demonstration, as they had confiscated weapons from FPI supporters from Surakarta, who had arrived in Jakarta by train the previous day. In order to solve any remaining issues, the police would meet with FPI representatives at the Department of Religion. Alam denied Shihab's allegations that the action of the police was to scapegoat FPI and prevent people from organizing any other anti-US demonstrations.

The third and final interview was with Andi F. Noya from Metro TV. Noya explained that a Metro TV cameraman had filmed the police attempting to disperse the demonstrators and destroying one of their cars. When the camera man refused to hand over his video-cassette and tried to flee, he was chased and hit by the police, and eventually forced to surrender the cassette. According to Noya, Metro TV would only broadcast the content of the confiscated cassette if they considered the information still to be relevant. Noya assured the decision would not be influenced by any pressure from or negotiation with the police. He could understand journalists sometimes had injuries from working in risky circumstances, but did not accept the police taking or destroying their materials and breaching the freedom of the press.

The specific ways in which the different parties answered questions and responded to the situation represented several sometimes confusing references or contributions to discourse and behaviour in alleged Reformasi style. The FPI, with its fundamentalist ideology and militant attitude, can be considered as an example of 'bad' civil society, which with the lessening of central state control seized the opportunity to manifest itself in public. Ironically, during the interview Shihab used 'good' civil society discourse - similar to the discourse used by IMLPC, for instance - attempting to convince the audience that FPI would not seek recourse to violent revenge, but rather contribute to 'upholding the supremacy of the law'. He also positioned FPI in the same victim's role as the press, thereby trying the audience to project some of 
the democratic values and functions of the press on to his own organization.

The fact that a high-ranking police representative publicly acknowledged and apologized for bad police behaviour in the media would have been unthinkable during the New Order. Alam used exactly the same phrase as Shihab about 'upholding the law', but also said that the police conduct was aimed at safeguarding the values of masyarakat madani ('civil society', with Islamic connotations, see Chapter III). Probably he used this late 1990s activist-scholarly term to imply that FPI did not act in accordance with what was envisioned as Reformasi-style social behaviour. Several times during the interview, he also underlined the importance of press freedom and the important role of journalists in society. Not surprisingly, this last point was confirmed by the representative from the media, Metro TV's Noya.

The interviewers confronted their guests with questions of equally critical intensity ('Why did FPI decide to demonstrate on a public holiday?', 'Why did the police confiscate media materials?', 'Why was Metro TV not prepared to bring the police to trial?'), although they approached each interviewee with a slightly different attitude. While not impatient with Shihab, the interviewers certainly attempted to prevent him from using his quite impressive oratory skills to manipulate the programme completely for FPI's own ideological ends. The interviewers applauded the superintendent's self-criticism, but in between, they also made some ironic comments on police conduct. With regard to their fellow journalist, Noya, there was an interesting combination of solidarity and professional rivalry.

During the talk show, the people interviewed did not have the opportunity to talk with each other, nor were there any phone-in opportunities for the listeners. In line with the idea of multi-sided journalism, the Trijaya hosts tried to give the interviewees equal time to present their own version of the story - without having to face the risk of endless interruptions - and provide the audience with the clearest possible overview of the different aspects of the case. Although this restricted dialogism in a narrow, literal sense, the talk show was certainly dialogic in a broader, Bakhtinian sense of ideological becoming, as it contributed to the audience's knowledge about the work of journalists, the mechanisms of media representation, and the function of a free press.

\section{'News-interaktif-solutif'; From practical solutions to sustainable development}

Interactivity on Indonesian radio has not only effects on a discursive level, enabling specific forms of journalism such as multi-sidedness, but also practical social implications. For instance, the Suara Surabaya interactive programmes showed that audience participation can lead to solutions to 
such diverse problems as tracing missing persons and reducing traffic jams. According to Suara Surabaya's brochure, the radio station in cooperation with its listeners has also been very successful in solving cases of car-theft. ${ }^{4}$ While Suara Surabaya listeners often debate relatively complex issues in the fields of politics, economy and culture, they are best known for providing information on and solutions to such down-to-earth matters of traffic, city infrastructure and criminality. In this way they give shape to Suara Surabaya's own concept of interactivity, which is summarized in the station's slogan 'News-interaktifsolutif' ('News, interactive, problem-solving'). The slogan indicates that the station expects its listeners not to provide mere opinion, but to contribute to the solution of the problems discussed in interactive talk shows.

Suara Surabaya, founded by Soetojo Soekomihardjo on 11 June 1983, was the first Indonesian commercial radio station with a news format. In order to circumvent New Order legislation that forbade news production by commercial stations, Suara Surabaya proclaimed that it did not produce news but information. This 'information' was inserted in talk shows in which listeners functioned as journalists and discussed all kinds of topical problems (Samuel 2002:308-10). Another strategy to overcome opposition from the authorities was to invite them for forum discussions on Suara Surabaya's management and broadcasting policies. These forums helped the station to receive the support of the governor of East Java and the regional parliament, and to establish good relationships with other official or professional institutions such as hospitals, the traffic police, the regional police and electricity and telecommunications companies (Titis Nurdiana and Andreas Berthoni 2002). These institutions together with the listeners remained Suara Surabaya's first-hand information sources after the fall of the New Order. Some of the station's other sources are the Internet and the national and international news agencies Antara (Indonesia), AFP (France) and Deutsche Welle (Germany) (Suara Surabaya 2002).

Every year, Suara Surabaya awards listeners as well as institutions for fruitful contributions to their programmes and society at large. ${ }^{5}$ Suara Surabaya's staff believes that the awards can help institutions redefine their role in society and create or regain a real public function, after so many of them

4 People whose car has been stolen can phone the radio station in order to have the theft and a description of the car announced on air. Listeners who spot the car on the road or in their neighborhood are expected to report this to Suara Surabaya or the police, although some listeners prefer to try and catch the thieves themselves. It is said that the victims of this type of criminality prefer calling Suara Surabaya to calling the police, as the radio station would be faster and more efficient. Sometimes the police themselves use Suara Surabaya as an information source, see Suara Surabaya 2002.

5 Suara Surabaya inspired another commercial radio station, Global FM, to organize its own competitions for listeners. 
were discredited for cases of corruption, collusion and nepotism during and after the Suharto regime. ${ }^{6}$ According to the staff, it is too easy a definition of Reformasi simply to criticize or disavow these institutions without allowing for constructive attempts at reform from within. What needed to be criticized were not the institutions as such, but the practices of some of their so-called representatives. ${ }^{7}$

Similar to Suara Surabaya, the Jakarta-based radio station Jakarta News FM, founded in 1998, also attempts to involve its listeners in news production as well as social activities. The station relies almost completely on funding by its listeners, as it is unable or unwilling to receive commercial funding. According to Nor Pud Binarto, Jakarta News FM's head, the station deliberately chose to be financially and ideologically independent of any sponsors. ${ }^{8}$

Jakarta News FM's crew consists predominantly of students and human rights activists. In news production and social off-air activities they pay special attention to street children, victims or witnesses of political violence, and peace movements. They interview people who do not have the means to phone in or come to the studio, and attempt to teach them how to speak in public and defend their rights. Binarto believes radio is a suitable medium for achieving these goals, as it responds to dominant oral traditions in society, can reach illiterate people, leaves room for people's imagination, and is in that sense less manipulative or 'refeudalizing' than television. ${ }^{9}$

In 2001, Jakarta News FM's news programmes included 'Headline news' (headlines of newspapers and news sites on the Internet), 'Paradigma publik' ('Public paradigm', with information on public services), 'Polling' (public opinion surveys), 'Reportase bursa' ('Stock exchange reportage'), 'Prognosis' (a news bulletin with audience participation), CNN news (relays from the American news channel) and 'Jakarta street views' (on-the-spot interviews with the Jakartan people). Jakarta News FM's talk shows on current affairs included 'Portopolio' ('Portfolio', with analyses of politics and the economy), 'Analisis topik' (interviews with experts on a topical issue), and the earlier discussed 'Sabtu bersama Ratna' and 'Ngobrol sama Dino'. The radio station's features and documentary programmes included 'Harmoni alam' ('The harmony of nature', a programme about environmental issues), 'Features anak jalanan' ('Features on street children', documenting the life of street children in

6 The regional government and other official organizations, joining in this culture of contests, sometimes also award Suara Surabaya listeners for social merits directly or indirectly facilitated by the medium of radio. According to Jonathans (personal communication, 24-7-2002), Suara Surabaya itself was once nominated for an award, but it refused to accept it in order not to lose its independence and credibility.

7 Errol Jonathans, personal communication, 24-7-2002.

8 Nor Pud Binarto, personal communication, Jakarta, 11-8-2001.

9 Nor Pud Binarto, personal communication, Jakarta, 11-8-2001. 
Jakarta), 'Features kesaksian' ('Features of testimony', containing stories of victims and witnesses of human rights abuse) and 'Features sang guru' ('Features on the teacher', containing reportages about school development projects).

Jakarta News FM also has its own social welfare organization, Rumah Bersama ('A House for All'). The people involved in Rumah Bersama describe themselves as 'a humanitarian working group for refugees and the urban poor' ${ }^{10}$ The organization, which is funded with donations from Jakarta News FM listeners, has been involved in projects such as the rebuilding and restoration of schools. ${ }^{11}$ Several off-air projects initiated and sponsored by Rumah Bersama constituted the main themes for episodes of the 'Features sang guru' series. This series illustrates how certain on-air interaction between hosts and listeners on Indonesian radio aims at and leads to the realization of concrete social development projects.

The 15 September 2001 episode, for instance, documented how the volunteers of Rumah Bersama together with a team of doctors went to the field in order to inspect the health of pupils at an elementary school in the Depok suburb of Jakarta, which was located near a garbage disposal. The feature was very 'lively' in Masduki's sense and tried to attract the attention and stimulate the involvement of the audience through the inclusion of voices and noises from the school children, interviews with a doctor and local people, and pop songs selected as background music or intermezzo.

After a short introduction in which the female presenter explained the purpose of the visit to the elementary school, the reportage started with a pupil rattling off a lesson about hygiene. Then the presenter explained: 'Behind the windows of the third grade [classroom] at the State Elementary School Cipayung 3, the pupils learn to improve their reading. But the other side of the teaching process is that outside the school there is a heavy traffic of garbage trucks. ${ }^{\prime 2}$ She also argued that the local Depok government only made vague promises and considered the health problems of the residents nothing to be worried about, in spite of the fact that the number of ill people had increased drastically. An interview between a Jakarta News FM reporter and a local resident inserted in the presenter's narrative illustrated and confirmed her argument.

The presenter then summarized the words of a medical doctor who was concerned that diseases would spread easily if the living conditions did not improve quickly. This explanation was followed by an insert with an inter-

10 Kelompok kerja kemanusiaan bagi pengungsi dan masyarakat miskin kota. http://www.sangguru.8m.com/favorite_links.html (accessed 15-9-2001).

11 http://www.sangguru.8m.com/about.html (accessed 15-9-2001).

12 Di balik jendela kelas tiga SD Negeri Cipayung 3 murid-murid belajar memperlancar membaca. Namun di balik proses mengajar, di luar sekolah mobil truk pengangkut sampah berseliweran. 
view between the Jakarta News FM reporter and the doctor. In all the interviews, background sounds of playing and studying school children could be heard, while the presenter's narrative was accompanied by soft melodic pop music. The programme also contained an intermezzo with the same type of music, which provided the programme with a sense of heroism and optimism about the attempts made to improve the situation.

The second part of the programme, after the intermezzo, also consisted of the presenter's narrative and interviews between reporters and local residents about the health programmes that had been attempted. According to government plans, the school could only be rebuilt at another location in three years time, so the local residents tried to find temporary solutions such as building fences around the garbage belt and campaigning for the waste to be dumped at other locations. Not coincidentally, the programme was directly followed by a socio-critical song of the famous Indonesian protest singer Iwan Fals.

By including songs, narratives, interviews and background sounds related to the themes of poverty, education and health, the 'Features sang guru' episode informed the listeners and stimulated them to formulate their own opinions. At the same time, the programme was meant to encourage the audience to provide physical or financial assistance to Rumah Bersama's social welfare projects and contribute to Jakarta public life in general as fully-fledged, active citizens.

\section{'Wandering around the city'; Virtual travel and regional awareness}

Earlier I argued that the type of citizenship created by Reformasi-style broadcasting has transnational characteristics, as it has been partly shaped by imported foreign ideas and practices. News stations often show pride in being part of larger communication networks and having the means or privilege to relay news from or disseminate information to distant places. The following Jakarta News FM jingle, for instance, creates an image of modernity and cosmopolitanism for the radio station and its listeners by mentioning the use of the prestigious technology of the Internet for reaching Indonesian people abroad.

Imagine a 'Jakarta listener' who is in London, then flies to Tibet. Today the world has become small indeed. Jakarta News FM can be listened to for 24 hours [a day] in every corner of the world. Just click: <www.indonesiamu.com $>$. Jakarta News FM is within your grasp indeed. Jakarta News FM online: 'World in your hand' $\left[\right.$ sic.$^{13}$

13 Bilamana Jakarta listener berada di London, kemudian terbang ke Tibet. Maka sekarang dunia menjadi sempit adanya. Jakarta News FM dapat didengar selama 24 jam di seluruh pen- 
Similarly, Global FM in Tabanan tries to earn prestige from its cooperation with the BBC as well as the satellite technology that makes this cooperation possible: 'You have just followed a direct satellite connection with BBC London. This direct broadcast was collaboratively organized by the Global FM network and BBC London.' ${ }^{14}$

Although Indonesian radio discourse has been partly shaped by and earns prestige from national and international ideas and practices, and partly turns its listeners into national or cosmopolitan citizens, the case of 'Features sang guru' confirms that it has had its greatest political and social resonance or impact at a regional level. Official New Order policy as reflected in the SARA doctrine admonished stations to keep the listeners at a distance and not cultivate regional sentiments, as any confirmation of the audience's regional and civilian identity was considered a potential threat to national political and social stability. However, since Reformasi broadened the space for regional culture and even regional autonomy, radio stations and other media institutions have wholeheartedly taken advantage of the possibility to renew the contact with their listeners and re-strengthen their regional cultural pride by focusing on the niche of regional culture and politics.

For instance, although Suara Surabaya is Indonesia's radio station with the largest number of listeners - several million people - and the highest advertising rates, it explicitly positions itself as a local news provider for Surabaya and surroundings, or 'the voice of Surabaya' (suara Surabaya). In a highly self-conscious manner, it refuses to make use of the services of international radio services such as Radio Nederland. Although Jonathans acknowledges the merits these news providers had in providing alternative sounds to the New Order propaganda, he believes their broadcasts have lost some of their relevance since the beginning of Reformasi. ${ }^{15}$ According to Jonathans, local stations are better equipped to produce programmes about local circumstances as they are amidst the events, while the international services operate from a distance and lack direct engagement as well as the relevant cultural and topical knowledge.

Suara Surabaya endeavours to present itself as the voice of the Surabaya region by means of the all day flow of broadcasts called 'Kelana kota' ('Wandering around the city'), which groups together news bulletins, talk shows and other programmes. 'Kelana kota' invites hosts, experts, journal-

\footnotetext{
juru dunia. Click saja: <www.indonesiamu.com $>$. Maka Jakarta News FM berada dalam genggaman Anda. Jakarta News FM online: 'World in your hand' (based on a recording of a 16-10-2001 broadcast).

14 Demikian sudah Anda ikuti hubungan langsung via satelit bersama BBC London. Siaran langsung ini terselenggara atas kerja sama Global FM network dan BBC London (based on a recording of a 10-7-2002 broadcast).

15 Errol Jonathans, personal communication, Surabaya, 24-7-2002.
} 


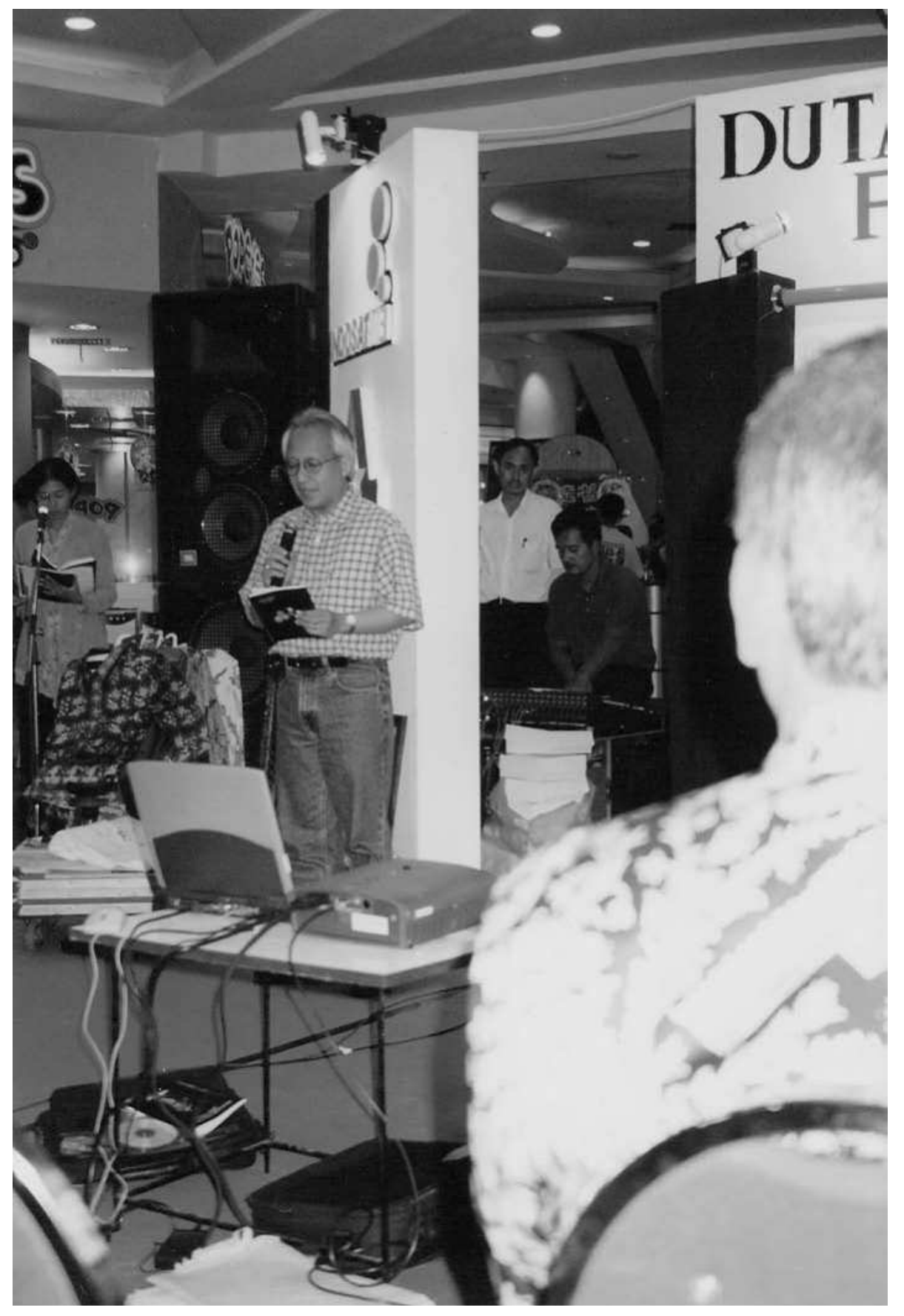

Suara Surabaya's programme manager Errol Jonathans, 2002 
ists and listeners to wander around Surabaya and surroundings physically or virtually, and in this way stimulates them to become more attentive to the peculiarities of their own region and community. Suara Surabaya listeners may sharpen their regional awareness and perform their regional citizenship through such down-to-earth activities as reporting about traffic jams or criminal acts in their neighbourhood. Other programmes produced by other stations have similar effects, such as Unisi's 'Jendela' ('Window'), which simultaneously attempts to promote the tourism business in Yogyakarta and develop the audience's regional pride and knowledge about their cultural heritage by providing a 'window' on important historical events and cultural sites in the area. ${ }^{16}$

Elsewhere, in Bali, a Global FM jingle makes it clear that 'Talking on Radio Global will show your quality and contribution to the Balinese cause'. ${ }^{17}$ In other words, participation in on-air discourse will enhance the prestige of the listener-participants, contribute to their personal development, and also benefit local society as a whole. The Global FM listeners show their concern about various aspects of Balinese life in programmes such as 'Citra Bali' ('The image of Bali') and 'Bali terkini' ('Bali update'). Together with the producers and consumers of the other media of the Bali Post Group, including newspapers, magazines and television, they have obtained and contributed to a renewed but not always uncontroversial Balinese self-consciousness.

One controversial concept in the Bali Post Group context is ajeg Bali ('firm Bali'), which is illustrative of the attempts of post-Suharto Indonesian media to mediate new forms of identity in response to international problems such as terrorism and local developments such as regional autonomy. According to Helen Creese

literally, ajeg mean 'strong' but it also implies tenacity and firmness; it encompasses all aspects of Balinese tradition, religion and culture (adat, agama, budaya), and represents a drive for stability and cultural certainty in a chaotic world (Creese 2004:2).

The concept of ajeg Bali or mengajegkan Bali ('making Bali firm') became popular after the first Bali bombings of October 2002 and only increased in popularity after the second bombings of October 2005 (I Nugrah Suryawan 2005:2). According to the Balinese scholar I Ngurah Suryawan (2005:9-10), the Bali Post Group management were the inventors of ajeg Bali shortly after the 2002 bombings. The idea was further promoted in political road shows

16 Unisi is a commercial radio station with a mixed format of news, education and religion, see Mardianto and Darmanto 2001:51-4.

17 Berbicara di Radio Global akan menunjukkan kwalitas diri Anda dan peran serta bagi kepentingan Bali (Jurriëns, transcription of an 11-7-2002 broadcast). 
in the Balinese regencies (kabupaten) that were supported by the governor of Bali, the head of the regional parliament (Dewan Perwakilan Rakyat Daerah, DPRD), the mayor of Denpasar, local regents (bupati) and other influential figures.

Both Creese and Suryawan have rightly criticized the ajeg Bali discourse for instilling a narrow Balinese Hindu nationalism that simplifies history and excludes groups in society. Suryawan (2005:5) points out the lurking dangers of cultural-religious essentialism and fundamentalism.

A greater downfall is an analysis that conveys that 'Firm Bali' also has to be 'Firm Hindu'. This creates a fortress and a discourse that can lead to the extremes of essentialism and, certainly, religious fundamentalism. Something that cannot be avoided, in spite of the fact that it has been endlessly disputed by the intellectuals of the Firm Bali 'think tank' [in English] themselves. This discourse thus creates a new politics of caution. Who is not 'Firmly Balinese'? Who is not guarding Balinese culture? A truth regime and the creation of a new person have begun to appear in Bali recently. A truth regime called 'Firm Bali' and a new Balinese people who are 'Firmly Balinese'. (I Nugrah Suryawan 2005:5.)

This new 'truth regime' or 'politics of caution' has been translated in local groups organizing raids in neighbourhoods in order to detect non-Balinese residents without valid identity cards, and ethnic Balinese business men uniting themselves in Koperasi Krama Bali (KKB, Balinese Citizen's Cooperatives) in order to protect their interests against non-Balinese competitors (I Nugrah Suryawan 2005:1-2, 17).

Creese (2004:1) argues that ajeg Bali and other forms of renewed culturalreligious puritanism have also strengthened patriarchal values that curb or exclude women in Balinese society. She observes that articles in the Bali Post newspaper include and acknowledge the issue of women's emancipation, but usually present it as part of the national agenda rather than a constructive element of 'Balineseness'. Topics such as women's employment, domestic violence and demonstrations led by women, if discussed at all, are rarely integrated in the paradigm of Balinese (female) cultural identity (Creese 2004:10). According to Creese

in the context of ajeg Bali and in the face of what appears to be widely held perceptions of the increasing burdens placed on Balinese women by the conflict between modernity and Balinese cultural values, the majority of recent media articles on women instead seek to describe and justify the special place which traditional Balinese culture provides for women, a position that even the benefits of modernity cannot displace (Creese 2004:11).

At the same time, however, Suryawan (2005:14) shows that artists and ordinary people also put the ajeg Bali discourse in perspective by 'parodying, 
ridiculizing or even ignoring it' (memparodikannya, mengejeknya, bahkan mengacuhkannya). Although the Bali Post Media Group has been influential in disseminating the idea of ajeg Bali, it also provides ample space for forums where audiences have the opportunity to criticize ajeg Bali and other developments in Balinese society, such as the letters to the editor in the Bali Post newspaper and interactive discussions at Global FM. There are also broadcast segments on Global FM specifically aimed at enhancing the audience's media literacy and making the audience aware of and thus less vulnerable to ideological manipulation by the media. Although the outcome of the interactions between the Bali Post media and their audiences may not always be satisfactory in terms of Indonesia's quest for democratization, it would be wrong to suggest that the process in which public debate takes place in Bali is entirely monopolized and controlled by the elite of politicians and media magnates. In the case of Global FM's interactive programmes, the openness of the way in which debate is conducted is remarkably progressive.

Suryadi (2005) has analysed media activities in the North Sumatran region of Riau that also aim at the rediscovery and redefinition of ethnic identity, in this case 'Malayness'. The most prominent among these is Riau TV (RTV), one of the several local television stations established since 2001, which broadcasts programmes that aim at the revitalization of Malayness, discuss the issue of regional autonomy, and even express the ambition of regional independence (Suryadi 2005:136). Many of the commercial radio stations in Riau began to focus on local ethnic identity during the Suharto regime. One of these, Radio Soreram Indah (RSI), has programmes such as 'Pantun Melayu' ('Malay pantun'), 'Syair Melayu' ('Malay poetry'), 'Dongeng Melayu' ('Malay legends') and interactive programmes on regional music and culture. In these programmes, not only standard Indonesian and Riau Malay are used, but also Minang, Kamper (a Minang dialect), Batak and Mandarin, in order to reflect and cater for the audience's diversity in Malayness (Suryadi 2005:144-8).

Some news radio stations also use regional languages in addition to standard Indonesian, especially in conversations on local issues between the host and listener-participants. Usually code-switching takes place, as in the cases of Global FM, Jakarta News FM, Unisi and Suara Padang, with host and listeners constantly shifting between standard Indonesian and Balinese, Jakarta dialect, Javanese and Minang respectively, and sometimes also peppering their conversations with English expressions. In programmes of other radio stations, code-switching is alternated with the sole use of the regional language.

The talk shows of Mora in Bandung are sometimes in Indonesian or a mix of Indonesian and Sundanese - the mother tongue of the majority of the listener-participants - but often also almost exclusively in Sundanese. The 
content of the majority of these talk shows is about legal issues in accordance with the radio station's affiliation to a lawyer's office. According to Mora's broadcasting policy, the use of Sundanese can create a bond of trust and intimacy between the host and the listeners, and make it easier for people to explain highly complicated matters with not just legal but also personal and emotional aspects. ${ }^{18}$

During phone-ins, Mora listeners often express their concern about local issues such as the worsening infrastructure of Bandung. Depending on the approach for discussing such topics, Indonesian, Sundanese, or a mixture of Indonesian, Sundanese and sometimes English is used. For instance, the following dialogue from a 4 October 2001 broadcast of 'Somasi' ('Injunction') was entirely in standard Indonesian.

Listener (L): I want to comment on the fact that the city of Bandung seems to have become increasingly chaotic.

Host $(\mathrm{H})$ : The traffic, or what do you mean, Brother Edo?

L: Yes, also the traffic. The development over the last ten years also does not seem to have gone right. There are only one or two things that seem [right]. [...] I compare it with... if you look at Central Java, East Java, the development seems to... seems to have gone right. The streets all seem to be good, wide, safe. But if you look at Bandung, particularly Bandung, West Java in general, the development of streets seems to have been wasted. I don't know whether my opinion is wrong. $\mathrm{H}$ : What you have just said is true, Brother Edo. Because I stayed for twenty years in East Java. In East Java even the streets that lead to small villages have been asphalted, Brother Edo. There aren't any streets with holes in them.

$\mathrm{L}$ : At the same time the number of cars is increasing. While the streets are still the old ones, many of which with holes in them, Brother Aditya. ${ }^{19}$

A similar dialogue from a 29 September 2001 episode of 'Saksi' ('Witness') was almost entirely in Sundanese, only occasionally mixed with Indonesian expressions (Indonesian translations in italics).

18 Personal communication, Taye Tayudin Dj., broadcast manager of Mora, Bandung, 27-92001.

19 Listener (L): Mau mengomentari kota Bandung makin semrawut kelihatannya.

Host (H): Di lalu lintasnya atau apanya Kang Edo?

L: Ya lalu lintas juga kan. Selama sepuluh tahun ini pembanganun juga tidak kelihatan benar kan. Cuma ada satu dua yang kelihatan gitu. [...] Saya membandingkan... melihat kan ke Jawa Tengah, Jawa Timur gitu ya, pembangunan itu kelihatannya itu kelihatan benar kan gitu, jalan-jalan pada bagus, lebar-lebar, aman, kelihatannya itu. Tapi lihat-lihat di Bandung itu, khususnya Bandung itu ya, umumnya Jawa Barat, pembangunan sih untuk jalan kan buang sekali. Kelihatannya. Nggak tahu ya, kalau memang salah pendapat saya gitu.

H: Itu betul Kang Edo, yang dikatakan Kang Edo tadi. Karena saya selama duapuluh tahun di Jawa Timur. Itu di Jawa Timur itu jalan ke desa-desa aja di-hotmik lho Kang Edo. Nggak ada yang barolong.

L: Sedangkan kendaraan kan makin lama makin banyak gitu ya. Sedangkan jalan yang lama aja, banyak yang berlobang itu, Bang Aditya (Jurriëns, transcription of a 4-10-2001 broadcast). 
Host $(\mathrm{H})$ : Because times are changing so quickly, certainly there are also riskincreasing things.

Listener (L): It is very different from when I was a child, Brother Ayo, and lived there. I was born here, I am originally from here, my grandparents were from here. I even danced at the audience hall here, I learned dancing... So I am confused to see that it has even become difficult if you want to walk on the pavement. Now, at my age, I cannot enjoy it, Brother Ayo. It will never be again like it was during my youth. It seems to have gone very far away.

$\mathrm{H}$ : Maybe our children and grandchildren will not be able to enjoy the same atmosphere as in the past again.

L: It will be difficult for our children and grandchildren, Brother Ayo, if they want to walk there. When I was still at elementary school until I went to secondary school...

$\mathrm{H}$ : In the past you could also play on the street.

L: Now it has become difficult... ${ }^{20}$

It is no coincidence that the difference in language in the two dialogues reflects a difference in topics and attitudes. In the first dialogue, in which standard Indonesian was used, the conversation partners decided to approach the problem of Bandung's infrastructure by talking about rather abstract issues such as city development policies. The second dialogue, which was predominantly in Sundanese, contained a much more informal feel with the listenerparticipant reflecting on her personal experiences and expectations with regard to the development of Bandung.

Similar to the listener-participants in the two dialogues above, many other audience members have also regretted Bandung's bad city-planning, causing problems such as traffic jams, floods, pollution, safety-risks and unattractive city design. The listeners' observations usually lead to general discussion about local politics and cultural affairs, and confirm that radio broadcasts can express and enhance people's awareness about the region where they live and stimulate them to exercise their rights and duties as fully-fledged citizens. In

20 Host $(\mathrm{H})$ : Margina dengan perubihan jaman nu sakieu pesatna, tangtos oge aya hal-hal nu nambih resiko.

Listener (L): Benten pisan Kang Ayo, nuju abdi masih budak keneh, tinggal di situ, lahir di sini, asli di sini, turunan di sini, bahkan kan tari di pendopo di dieu, belajar tari... Janten abdi teh nepi bingung meningali teh hoyong leumpang dina trotoar oge meuning hese. Ayeuna pas usia sakieunya tidak bisa menikmati, Kang Ayo. Kapan saperti waktu kecil mah meureun moal sigana mah tebih teuing ya.

H: Waktos meureun kali turunan-turunan urang ya tidak bisa menikmati suasana sapertos pungkur deui itu.

L: Pas turunan-turunan urang gitu ya, Kang Ayo, mau jalan di situ meureun hese. Kapungkur mah nuju abdi budak panti SD sampai ka SMU...

H: Ulin-ulinan oge tiasa di jalan kapungkur mah.

L: Ayeuna mah pan hariwang... (Jurriëns, transcription of a 29-9-2001 broadcast). 
other respects, however, Mora is highly controversial in terms of the public values it claims to represent.

\section{Talk-back radio and the refeudalization of the public sphere?}

Mora has created a unique segment of the Indonesian radio market by combining current affairs with information and advice on legal issues. This has been a successful formula, as both items are in high demand in the context of the social and political reform in contemporary Indonesia. At the same time, controversy has arisen about whether the station serves the public cause indeed, or, in line with Habermas' pessimistic view of the mass media refeudalizing society, whether it merely stages displays of publicness to the benefit of its own commercial interests.

Mora received an official broadcasting license in 1999, after the abolition of the Ministry of Information. The radio station had trial broadcasts from 1985 until 1987, but failed to receive official recognition by the New Order broadcasting authorities because of its information-oriented format. ${ }^{21}$ By choosing the name Mora and focusing on the format of news and information, the Mora crew aroused the anger of the crew of Mara, another commercial news station in Bandung, which had its name and format from the late 1960s, long before Mora did. According to Layla S. Mirza, head of Mara, Mora in a cheap manner attempted to benefit from Mara's long history and good reputation in radio journalism. ${ }^{22}$ The people from Mora claim, however, that Mora was just an abbreviation of the name of its owner, Monang Saragih, and that they have a different approach in presenting news than Mara, which does not have in-house expertise in legal issues.

The majority of Mora's programme hosts are indeed lawyers. Monang Saragih is also a lawyer, who besides the radio station owns his own lawyers office. It is the close cooperation between Saragih's two businesses - which are even at the same physical location - that raises questions about the sincerity of the information and advice provided by Mora. Do the Mora hosts serve the private and public interests of the listeners, or rather attempt to instil motivation in the audience to make use of the commercial services of Saragih's legal office? My analysis of the interaction between host and listener in one of Mora's interactive programmes will show there is no univocal answer to this question.

From Monday until Saturday, each day at the same times, Mora broadcasts the same seven programmes. Three of these programmes contain light

21 Taye Tayudin Dj., personal communication, Bandung, 27-9-2001.

22 Layla S. Mirza, personal communication, Bandung, 28-9-2001. 
infotainment about regional culture and religion, three other programmes are about legal issues, and one programme, broadcast twice an hour, is dedicated to current affairs. The Sunday broadcasting schedule is dominated by popular music. The radio station also organizes off-air activities, such as law seminars and broadcasting workshops.

Mora's current affairs programme is 'Somasi' ('Injunction'; also an abbreviation for sorotan masalah dan situasi, 'clarifications of problems and situations'), which contains information about economic, political, cultural and social affairs in Bandung and surroundings. Mora receives the information from its own reporters, and only broadcasts national or international news when it is considered of direct importance to the local situation, such as news about the fall of an Indonesian president or international terrorist attacks. The Mora crew considers radio a local medium and believes it is unrealistic to try and compete with national and international news media. ${ }^{23}$ In interactive programmes, hosts and listeners often show a regional patriotic pride and concern about Bandung and West Java, as illustrated by the two earlier dialogues on Bandung's city infrastructure.

The three programmes about legal issues are 'Saksi', 'Kasasi' and 'Mora interaktif', all with a talk show format. 'Saksi' ('Witness'; also an abbreviation for saran komentar dan informasi, 'suggestions for comments and information') is a talk show in which listeners can request legal advice. In 'Kasasi' ('Cassation'; also an abbreviation for kasus dari sana-sini, 'cases from everywhere') cases from Saragih's legal office are discussed. In 'Mora interaktif' ('Interactive Mora') listeners have interactive discussions with experts in the studio about legal issues as well as topics of a more general social, political or religious nature.

A major challenge for the Mora programme hosts is how to translate legal problems into a language that suits the medium of radio. Messages have to be short and attractive, but still cover the essence of a topic. The few Mora hosts who are not lawyers by profession obtain training from lecturers in law at Padjadjaran University, Bandung, and other legal specialists and practitioners. As demonstrated earlier, the hosts also need to know Sundanese for smoothing their interactions with the listener-participants. ${ }^{24}$

The Mora hosts show their expertise by providing the listeners with legal advice, explanations about new government legislation and information about legal aspects of other public issues, such as the violation of human rights. Often listeners request information about legal matters they are confronted with in their daily lives, such as the lodging of an application for an identity card or birth certificate. Listeners are not charged for the on- 
air advice by Mora's hosts, but they do have to pay for legal assistance by Saragih's legal office (Mora 2001).

As the Mora hosts receive money for every case they are able to hand over to the legal office, they never enter the debates about the law and legal issues completely unbiased or without self-interest. In talk shows, hosts also discuss cases that have already been handled by the lawyer's office. Although the radio station explicitly presents itself as a 'public' station, it is clear that under the veneer of its publicness it predominantly serves as a popular communication channel for attracting new clients and advertisers, and promoting and expanding Saragih's legal business.

An example is the 29 September 2001 episode of 'Kasasi', in which a listener phoned in on behalf of 'a friend' or herself - this was not entirely clear - about problems that had arisen because of plans to marry a man with a different religious background. The parents of the woman disagreed with the proposed marriage, had the man captured by the police, and threatened to have him dismissed from his job. The listener asked the talk show host whether there was any legal ground for the parents to have the man put in jail, have him fired, or otherwise obstruct the relationship. The host explained that there was no Indonesian law that could prevent people from loving each other, even if they were from different religious backgrounds. Legal action could only be undertaken if one of the partners was under the age of eighteen, which was not the case. If the man was put into jail, the couple had the right to sue the police for unlawful imprisonment. According to the host, the easiest way to solve problems was if one of the partners changed religion and the couple got married legally. If the girl's relatives would not agree with her changing religion, she had the right to use a third party as a witness to the marriage. The listener specifically wanted to know whether legal action could be taken against the police for capturing her partner. The host directly provided some general information on the air, but apparently also saw an opportunity for Saragih's legal office to handle the case. When the listener was about to hang up the phone, he quickly invited her to come to the radio studio or legal office for more detailed information.

Listener (L): But, for instance, if the police was determined. For instance, if they already knew that there was no connection, there was no criminal aspect to the case, for instance. They [the couple] could in return, er, in return sue the police, couldn't they?

Host $(\mathrm{H})$ : Yes, they could. If the police have done something to him [the boyfriend], that is, if they have arrested or captured him. In that case they can sue the police in return. But not if the police just searched for the man or interrogated him. That's nothing; that does not count. Then they cannot sue them in return, Madam. Only if it is based on the police capturing him, the police arresting him, putting him in prison, then they can sue them in return, Madam. The police will then be put on trial for capturing someone without any clear grounds for a criminal case. 
L: Alright, thanks, Mr Heru [indicating she wants to hang up the phone].

$\mathrm{H}$ : The main thing is, just send her here Madam, er, your friend, just send her here with her boyfriend. But really, Madam, what I have just proposed will not solve the problem. That is...

L: At what time, Mr Heru? I mean, when is it possible?

$\mathrm{H}$ : Monday will be fine. Monday, Madam.

L: What time on Monday, Sir?

H: Monday, Monday until... Monday until Friday from eight until...

L: Monday until Friday...

H: Yes, from 8 a.m. until 5 p.m. I am at the office all the time.

L: To Radio Mora?

H: Yes, Madam, at Jalan Peta number 38.

L: Directly with you, or how?

$\mathrm{H}$ : Yes, you can meet me, Mr Heru, or my friends, Madam. Mr Dede Mulyana will be there, Mr Anwar, Mr Ferdinand Siregar. You can look for those people. If not, you may also meet directly with Mr Monang. ${ }^{25}$

The Bandung public is not unaware of the ambiguous nature of the radio station. For instance, in August 2003, hundreds of employees of the ailing Indonesian aircraft maker Dirgantara were on the city streets heading towards the Mora studio. The employees of Dirgantara, who were in a legal conflict with the company's management, accused Mora of biased news

25 Listener (L): Tapi misalnya, kalau pulisi udah nekat gitu ya. Udah tahu misal kan, nggak ada hubungannya, nggak ada unsur pidana gitu, misalnya, mereka gitu balik, balik, me-... apa itu, menuntut pulisi itu, bisa, berarti ya?

Host (H): Ya, bisa aja. Kalau udah diapa-apain ama pulisi gitu, artinya udah ditahan, ya kan, ditangkap, ya kan. Itu bisa nuntut balik pulisi. Tapi kalau cuma dicarian doang, atau ditanyatanyain doang, itu nggak apa-apa, nggak apa-apa adanya. Nggak bisa nuntut balik itu, Bu. Kecuali kalau atas dasar seperti itu, pulisi nangkap, pulisi nahan gitu, dipenjara, itu bisa nuntut balik, Bu. Di pra-peradilan pulisi nanti gitu. Nangkapi seseorang tanpa dasar tindak pindana yang jelas gitu.

L: O ya deh, makasih ya, Pak Heru.

$\mathrm{H}$ : Pokoknya suruh ke sini aja Bu, er, itu, teman Ibu itu, suruh ke sini ama cowoknya gitu ya. Tapi memang begini, Ibu ya, artinya, ya, apa yang saya sarankan tadi itu nggak menyelesaikan masalah gitu, artinya ya...

L: Jam berapa ya, Pak Heru, ya? Kapan gitu maksudnya bisa?

$\mathrm{H}$ : Seninlah. Senin Bu.

L: Senin jam berapa ya, Pak?

H: Senin, Senin sampai... Senin sampai Jumat dari jam 8 sampai...

L: Senin sampai Jumat...

H: Ya, jam 8 sampai 5 sore. Saya ada di kantor terus.

L: Ke Radio Mora?

$\mathrm{H}$ : Ya Bu, di Jalan Peta 38 gitu.

L: Dengan Pak Heru langsung atau gimana?

$\mathrm{H}$ : Ya, bisa nemuin saya, Pak Heru, atau teman-teman saya yang lain gitu, Bu. Di sana nanti ada Pak Dede Mulyana, Pak Anwar gitu, Pak Ferdinand Siregar. Bu cari orang-orang itu. Kalau nggak, ketemu langsung Pak Monang juga boleh (Jurriëns, transcription of a 29-9-2001 broadcast). 
reporting. They claimed Mora favoured the management's case, especially since Monang Saragih was appointed the management's defence lawyer. ${ }^{26}$ They felt betrayed, as Saragih and his radio station were initially thought to favour their case. During the demonstration, the angry crowd broke some of the radio station's windows, while shouting that 'Radio Mora was no longer defending the small people' (Radio Mora tidak membela wong cilik lagi). ${ }^{27}$

\section{Media literacy}

Aware of the danger of the refeudalization of the public sphere in cases such as Mora's, radio institutions in late- and post-Suharto Indonesia have developed programmes aimed at making audiences media-literate or mediasavvy. An example discussed earlier was the IMLPC programmes on media legislation and other media-related issues. These programmes were not interactive and did not offer opportunities for dynamic discussions with direct audience input. A different programme, in which media-related issues are always discussed in lively interaction with the listeners, is 'Lembaga konsumen media', produced by Suara Surabaya in co-operation with Lembaga Konsumen Media (LKM, Institute of Media Consumers).

LKM, initially called Lembaga Konsumen Pers (LKP, Institute of Press Consumers), was one of the first Indonesian media watch organizations, founded by the journalist and university lecturer Sirikit Syah in Surabaya, 1999 (Sirikit Syah 2000). In the weekly radio programme, LKM representatives together with the Suara Surabaya host and listeners discuss the content and impact of different types of media, including magazines, billboards, television soaps and radio bulletins, as well as the rights and responsibilities of the listeners as information consumers. ${ }^{28}$ In addition to co-producing the radio programme, LKM also keeps records of offences by the press, publishes newsletters with feedback for press organizations considered to have harmed the public interest, and organizes workshops and seminars on the role of media in the public sphere (Sirikit Syah 2000).

In 'Lembaga konsumen media', listeners explore and negotiate the rules of discursive interchange by expressing their own experiences in dealing with the media. In order to demonstrate how the programme attempts to guide listeners through this literally dialogical process of ideological becom-

26 'Karyawan PT DI masih berdemo', Suara Pembaruan.

http://www.suarapembaruan.com/News/2003/08/14/Ekonomi/eko15.htm (accessed 14-8-2003).

27 'Aksi unjuk rasa karyawan PT DI diwarnai insiden', Kompas.

http://kompas.com/kompas-cetak/0308/14/daerah/492040.htm (accessed 14-8-2003).

28 Based on Meinara Iman D., news director at Suara Surabaya, personal communication, 24-7-2002, and recordings of 2002 broadcasts. 
ing, I will focus on a 23 July 2002 broadcast that was about advertisements promoting the use of condoms in the fight against HIV/Aids. The Suara Surabaya host, Meinara Iman, talked about these advertisements with the LKM advisor Tjuk Suwarsono, the sexologist Doctor Andi Wijaya, and the listeners. The advertisements were controversial as they touched on a taboo subject in Indonesian society, the issue of pre-marital sex.

The one-hour episode started with Wijaya arguing that the risk of the advertisements was that people, especially youth, could derive a false sense of safety from using condoms. Wijaya referred to data from the United States, which showed that in thirteen per cent of cases condoms failed to offer sufficient protection. According to Wijaya, abstinence was a far more reliable method. He also thought the condom campaign should have been targeted specifically at groups with a high-risk lifestyle, and not the general public. After this introduction, the listeners, addressed as konsumen media ('media consumers'), were invited to give their own opinion on the issue.

Some of the listener-participants agreed with Wijaya. They were not necessarily against condom use, but thought the campaign should have been targeted at adults only.

Actually it should not be the case that because we, adult people, cannot control ourselves, the government has to recommend us to use condoms, which causes these children to misuse them, and so on. I also want to suggest that maybe the mass media, when socializing and helping the government with social health services, should not publish [information] directly in the newspaper. Maybe they can print a special brochure or something, and distribute it to adults only. ${ }^{29}$

Others argued, however, that the main issue was not the publicness and accessibility of the advertisements, but the personal attitude of the media consumers.

According to me, it is 'up to the person itself' [sic], Sir. Whether someone wants them [condoms] or not is their own responsibility. So in my view, just let the publication of condom advertisements go. So, it is up to the person who reads them. That's all, Sir. ${ }^{30}$

29 Sebetulnya kan ulah kita-kita orang dewasa yang tidak bisa mengontrol diri, sehingga pemerintah perlu memberikan anjuran untuk memakai kondom tersebut ya sehingga yang mana mengakibatkan anak-anak ini menyalahgunakan dan lain sebagainya ya. Saya juga ingin mengusulkan, mungkin media massa dalam rangka menyosialisasikan dan membantu pemerintah dalam layanan kesehatan masyarakat tersebut mungkin jangan langsung dicetak di koran. Mungkin bisa dicetak brosur tersendiri atau bagaimana, disebarkan hanya kepada orang dewasa saja (Jurriëns, transcription of a 23-7-2002 broadcast).

30 Kalau menurut saya, 'up to the person itself', Pak. Apakah dia mau apakah dia tidak, dia harus bertanggunjawab. Jadi menurut pendapat saya itu, pemasangan iklan tentang kondom itu, ya terserah aja. Jadi, jadi orang yang membacanya. Gitu aja, Pak (Jurriëns, transcription of a 23-7-2002 broadcast). 
In the final part of the programme, Wijaya summarized some of the points made by the listeners and provided advice for media producers and consumers. Similar to Hinca Pandjaitan's argument about hak menjawab ('the right of reply') in the IMLPC programmes, Wijaya emphasized the right of media consumers to protest if they did not agree with certain messages in the media. He also urged parents to spend as much time as possible with their children in order to protect and guide them, and teach them proper values. The host ended the programme by expressing the hope that the information provided by Wijaya and the listeners would contribute to the improvement of future media campaigns about HIV/Aids.

In 'Lembaga konsumen media', Suara Surabaya uses this type of debate to address the rights and responsibilities of media producers and audiences. In general, the different discussion partners do not argue for a return to a New Order-type control of the media, but try to explore and negotiate the boundaries of the press' Fourth Branch function in the context of Reformasi. In 'Lembaga konsumen media' and other talk shows, Suara Surabaya promotes media literacy not only by addressing the media content audiences are confronted with in their daily lives, but also by giving listeners the opportunity to talk about their own or the hosts' performances as participants in radio talk shows. The following chapter will show that this Suara Surabaya model of meta-journalism has also become a source of inspiration for other Indonesian radio stations in their attempts to raise media literacy. 


\section{Chapter viI}

\section{The discipline of talking}

Although it is not uncommon for Indonesian current affairs programmes to be interactive and allow participants to reverse roles - with hosts becoming experts or listeners becoming reporters, for instance - it is less common that the performance of participants and the effects of their role-reversal become topics of on-air debate. Global FM in Tabanan, Bali, is one of the few commercial radio stations that have made such debate a standard, integral part of programmes and activities. This chapter will focus on Global FM's interactive talk shows and off-air meetings in which radio crew, listeners and representatives of politics and business talk about democracy, radio discourse, and the preferred direction of Indonesian radio journalism in times of Reformasi. The chapter also discusses the radio station's annual competition in which listeners can be awarded the title of 'Social empowerment personality' for their contribution to the development of radio discourse, or for being beneficial to Balinese society in other ways.

\section{The media of the Bali Post Group}

Global FM is Bali's most popular radio station. It is an institutional part of the Bali Post Media Group, which also consists of the regional newspapers Bali Post (news about Bali), Den Post (news about Denpasar) and Bisnis Bali (business news); the national tabloid Tokoh ('Personality'; about celebrities); the English-language tourism magazine Bali Travel News; the news radio stations Singaraja FM (broadcasting in Singaraja and surroundings) and Radio Besakih (broadcasting in Besakih and surroundings); the cultural radio station Genta Bali ('Bali Bell', broadcasting in Denpasar and surroundings); and the television station Bali TV, which broadcasts regional news, cultural programmes and entertainment in Indonesian and English, and can be received in Bali by antenna and other parts of Asia, Australia and New Zealand by satellite. The different media of the media group are strongly interconnected, sharing resources, news stories and forums for discussion on media and society. 
Ketut Nadha founded the group in 1948, starting with the magazine Suara Indonesia, the predecessor of the Bali Post newspaper. The Bali Post is among the oldest of Indonesia's existing newspapers and one of a minority of regional papers independent of the media conglomerates (Warren 1994:2). It 'adopted populist and nationalist commitments from its inception' - which is today reflected in its commitment to the ajeg Bali movement - and is 'fiercely committed to maintaining local ownership' (Warren 1994:2). The current owner of the media group is A.B.G. Satria Naradha, Ketut Nadha's son. ${ }^{1}$

The Bali Post Group started Global FM a month before the general elections of June 1999, the first democratic elections in Indonesia since 1955. According to a Global FM crew member, radio was the fastest, cheapest and most accessible medium for covering the elections and carefully monitoring the election procedures. ${ }^{2}$ After the elections, Global FM preserved its news format and continued to monitor public events and institutions in cooperation with its audience, the media of the Bali Post Group and other information providers.

The radio station website lists 'Bali terkini' ('Bali update'; from 3 to 4 p.m. daily, except for Sundays), 'Citra Bali' ('Image of Bali'; daily from 8 to 9 a.m.), 'Warung Global' ('Global food stall'; daily from 2:15 to 3 p.m.), 'Global terkini' ('Global update'; broadcast several times a day between 9 a.m. and 10 p.m.), 'Lintasan berita' ('News flash'; daily from 9 a.m. to 9 p.m.), 'Lagu-lagu Bali' ('Balinese songs'; Sundays from 2 to 4 p.m.), and 'Dharma tula' ('Religious duty'; Fridays from 8:15 to 9 p.m.) as the station's core programmes. ' 'Global terkini' and 'Lintasan berita' include local, national and international news. 'Lagu-lagu Bali' contains Balinese pop songs, while 'Dharma tula' is an interactive discussion programme about Hinduism. 'Bali terkini', 'Citra Bali' and 'Warung Global' are current affairs talk shows.

The last three programmes not only depend on interactivity with the listeners, but also with the other Bali Post Group media. Summaries of listeners' individual contributions to 'Warung Global' and 'Bali terkini' are published daily on half a page of Bali Post and summaries of their contributions to 'Citra Bali' on one-third of a page in Den Post. Bali Post also publishes Bali TV's programme schedule and represents the results of Bali TV's interactive talk shows daily. Den Post announces the topic of the day to be discussed in Genta Bali's interactive talk show 'Warung Bali' ('Balinese food stall') and reports on the previous day's show. These reports contain summaries of what people said on air, including their main criticism, questions or remarks. The readers

1 Arya Dikara, personal communication, Tabanan, 10-7-2002; http://www.balipost.co.id (accessed 10-7-2002).

2 Arya Dikara, personal communication, Tabanan, 10-7-2002.

3 http://www.globalfmbali.com (accessed 10-7-2002). 
of Bali Post and Den Post are free to comment on the opinions of radio listeners and television viewers published in the newspapers. By receiving and publishing the letters of these readers, the two newspapers create their own form of interactivity.

Global FM's programmes 'Bali terkini', which is relayed by Radio Besakih and Singaraja FM, and 'Citra Bali', which is relayed by Genta Bali and Singaraja FM, include listeners' comments on a rich variety of topics, ranging from criminality to the use of public space and money. Bali Post has a rubric called 'Tanggapan Bali terkini' ('Reactions to Bali terkini') in which people offer written reactions to the contents of the radio programme. Usually representatives of public service institutions such as schools, the regional parliament or the national electricity company use this opportunity in order to provide information or defend themselves against charges made by listeners. The talk show 'Warung Global', relayed by Genta Bali and Singaraja FM, focuses on a single topic often related to politics, culture or economy in Bali. The synopses of Global FM's talk shows, written by Bali Post and Den Post journalists, give detailed accounts of individual listeners' comments, including their names and addresses.

The Bali Post Group management believes the strong interconnectivity between the different media branches provides several advantages. First, it provides the financial advantage of selling a larger market to advertisers. Second, it allows for a reduction of costs, as the branches can benefit from a mutual exchange of expertise, technology and products. For instance, Global FM regularly contacts Bali Post journalists for information, while Bali Post in turn makes use of the information generated in Global FM's programmes. ${ }^{4}$ Third, the management believes this interconnectivity provides a multitude of forums for public opinion and stimulates the dialogue between citizens and official representatives. Indeed listeners feel encouraged to talk on air, when they know that their names and comments may appear in the newspaper or on television. Double or triple media attention not only provides them with personal prestige, but also enhances the strength and scope of their statements. Radio's speed and accessibility, combined with the durability and comprehensiveness of the newspaper and the visual attractiveness of television, seems to convince the audience or listeners to act, especially when

4 It is noteworthy in this context that Indonesian media activists in anticipation of the 2002 Indonesian Broadcasting Law were pleading for a ban on media cross-ownership, arguing that it would lead to the monopolization of public opinion in geographical areas. Even if this plea was of direct concern to the media interconnectivity of the Bali Post Group - which it was not - it would indeed have been difficult to measure whether the group monopolizes public opinion in Bali, as the Balinese media scene is constituted by an amalgam of regional, local and international media forces. 
they are aware that the same combination of stimuli will force other people, including government representatives, to react. In this way, the media group gives expression to Reformasi calls for the accountability and transparency of official institutions.

Bali Post Group's role in organizing public discussion is not neutral, since it has certain rules to which listeners, readers and viewers have to adhere for access and participation in interactive debate. For instance, the opinions of the listeners of Global FM's talk show 'Citra Bali' are only published in Den Post if these listeners provide their real names and telephone numbers, do not insult or offend other people, and provide new information or themes. These apparently general criteria become much more compelling in the real interaction between host and listener, or editor and reader, when 'an insult' or 'new information' happens to be subject to specific, either individual or corporate, interpretations.

During live discourses, talk show hosts also have the power to provide or deny listeners access to the programme, decide on the topic of conversation and regulate the duration and tone of speech. At the same time, however, the audience is allowed and encouraged not only to comment on current affairs, but also to discuss and criticize the format of the programmes themselves. Through this specific type of meta-journalism, the listeners are made aware of the ideological principles behind (radio) discourse and have the power to demand changes in communication mechanisms or broadcasting structures.

\section{Global FM; 'Don't be unwilling to talk'}

Global FM's proposition that programme hosts and their audiences are able to cooperate to further develop the format of talk-back radio, increase the standard of Indonesian radio journalism and improve the quality of Balinese society is illustrated by the evolution of the radio station's slogans. Since its birth in 1999, the radio station has featured the motto 'De koh ngomong', Balinese for: 'Don't be unwilling to talk. ${ }^{5}$ The motto has encouraged listeners to talk on air and give their opinions about topics discussed in Global FM broadcasts and society at large. This message has also been echoed in other broadcast items, such as jingles. For instance, a jingle for the programme 'Bali terkini', which creatively played on different meanings of the word suara which can either refer to 'sound' or 'voice' - also admonished people not to be unwilling to talk, and to give expression to their own thoughts and feelings about socially relevant issues. 
The time has come for us to listen to sounds. The time has come for us to listen to the sound of nature [followed by an insert containing animal sounds]. The sounds of human inventions [followed by an insert containing the sounds of engines]. And now the time has come for us to listen to your sounds/voices. Your voice is the authentic voice of the people [followed by an insert containing conversations in Global FM talk shows]. Let your inner voice speak in the programme 'Bali terkini'. Your voices concerning social problems and environmental, cultural, criminal and public service problems [followed by an insert containing Balinese music and jingles for other Bali Post Group media]. Call 815224 or 419915 . Your voices will be heard on Global FM by many people and certainly be read in the Bali Post daily by many people. 'Bali terkini', follow it from 3 to 4 p.m. on Global FM. ${ }^{6}$

The listeners, apparently caught up in the spirit of Reformasi, reacted en masse to these messages. Initially, the idea of 'Don't be unwilling to talk' almost died from its own success because of ensuing 'chaos'. Often, a listener would not listen to the arguments of other participants or the host and become angry, yelling at other participants or not letting them talk at all. Both the hosts and the listener-participants were dissatisfied with the way in which the discussions took place, and felt the need for the development and nurtering of an 'ethics' for talking on the air.

After a testing period of several months, Global FM began to combine the initial motto with slogans such as 'Saatnya mendengar, saatnya bicara, saatnya berdaya' ('There are moments to listen, moments to speak, moments to act') and 'Melahang ngomong' (Balinese for: 'Improve your talk'). These slogans advertised on the air and in newspapers and magazines reflect the ambition of the Global FM producers and listeners to improve the performance of the participants in on-air discussions as well as the quality of the genre as a whole. The participants have to learn to give space to the opinions of others ('There are moments to listen'), to decide on the appropriate moment for expressing their own opinion ('There are moments to speak') and to learn to speak in a clear and courteous manner ('Improve your talk'). The interactivity paradigm also establishes strong disciplinary links between 'acting' ('There are moments to act') and talking and listening, and defines social activity as being embedded in discursive interaction or constituting a result of it. It summons listeners to be cautious in assessing when and how to synthesize

6 Sudah saatnya kita mendengarkan suara-suara. Sudah saatnya kita mendengarkan suara alam. Suara-suara hasil cipta karya manusia. Dan kini sudah saatnya kita mendengarkan suarasuara Anda. Suara Anda adalah suara rakyat asli. Sampaikan suara hati nurani Anda dalam acara 'Bali terkini'. Suara-suara Anda untuk masalah sosial, masalah lingkungan, budaya, kriminal, layanan umum. Hubungi pesawat 815224 dan 419915. Suara-suara Anda akan didengar banyak orang di Global FM dan tentu akan dibaca banyak orang di harian Bali post. 'Bali terkini' ikuti dari pukul 15 sampai dengan 16 di Global FM (Jurriëns, transcription of an 11-7-2002 broadcast). 
talking and listening - combining their own arguments and the arguments of others - and when and how to draw conclusions, make decisions or leave the discussion.

Another means through which Global FM underlines the strong link between radio talk and social action is the annual elections of the ten most prominent listener-participants. In this competition - another exponent of the Indonesian culture of contests - listeners are awarded titles that are more than mere 'Best listeners' or something similarly plain, but that of 'Tokoh pemberdayaan masyarakat' ('Social empowerment personalities'), indicating that the way they performed during, and possibly outside, Global FM broadcasts has made a positive difference to Balinese society. By being awarded the title of 'Tokoh' ('prominent person', usually in art, culture, politics), these listeners also gain social status, at least among the listeners of Global FM. This is a title many of the awarded listeners could not have easily received in 'normal' society, simply because their low educational background or lack of financial means would have prevented them from having any influence or undertaking any action. ${ }^{7}$

\section{The discipline of talking; 'Global terkini' and 'Jumpa pendengar'}

The talk show 'Global terkini' ('Global update') provides a fascinating example of how hosts, listeners, experts and others in interactive Global FM broadcasts attempt to negotiate discussion topics as well as speech patterns and social behaviour with each other. In spite of the steering role of the host, the open format of 'Global terkini' is remarkable. The programme does not have a pre-fixed topic at the start, but invites listeners to phone in to discuss any news item they want. The host invites two callers at a time to have a dialogue. After a while one or both of the callers will quit the programme, and new listeners are invited, sometimes three at a time. The new participant(s) may continue on the same topic as the previous participants or introduce a new issue. In general, after a few calls the discussion becomes focused on one particular item.

For instance, the main item of the 11 July 2002 'Global terkini' broadcast was the announcement that the following day all taxis in Bali would increase their price by thirty per cent. The host and the listeners decided to focus on this topic only after what could be called an open, multi-directional or even chaotic start. The programme started with Bram, the host, receiving a call

7 In general, Global FM attracts listeners from many different social backgrounds, although it formally targets a middle-class audience. 
from a listener who had read a book in which the main argument was that poor countries like Indonesia were poor due to the defaults of their own political culture, such as corruption, hypocrisy, treason and laziness. A second caller on a mobile phone joined in, but left soon as he had 'to do some shopping first'. A third caller's phone stalled after he had made some unrelated jokes but before he could offer a more serious contribution. Then the host received the second caller again, who had just finished shopping. This second caller happened to be Kadek Mako, an active participant in Global FM's broadcasts and one of the persons awarded the title of 'Social empowerment personality'.

Initially Mako made some general remarks about the theme mentioned by the first caller, who was still on the air. However, after the first caller had recognized him, an abrupt change of topic and role took place. The first listener became an interviewer - a position usually occupied by the host - and Mako an expert - a position usually occupied by external specialists. The host became partly overhearer - a position usually occupied by the home audience - partly moderator of the interview - a role more conventional, though still not very active, for a host. The 'interview' evolved around local politics in Gianyar, the place where Mako lives and where he is well known for participating in Global FM broadcasts. After the conversation had reached a conclusion and the host had said farewell to the two listeners, there was a brief musical interlude with a song requested by the first caller, and a newsbreak about a ferry that was stranded between Java and Bali.

After the break, the hosts allowed a new caller, who commented on the stranded ferry and argued that for years he had pleaded for a bridge to be built between Java (Ketapang) and Bali (Gilimanuk) to prevent any further accidents in the sea. When the host heard the caller's friend murmuring in the background, he asked who it was and what he was talking about. The caller answered that it was his friend, a taxi driver, happy about the higher prices he could ask the next day. The host who until now had hardly participated in the debate tried to get the discussion focused on this particular topic by continually asking the two friends questions about taxis and their prices. Later other listeners joined in on the same issue - most of them taxi drivers themselves - and, relatively spontaneously, a central topic for debate was born. The process of 'thickening' a discussion by first narrowing the range of topics and eventually attempting to enhance the quality of arguments or reaching some kind of conclusion or consensus was best summarized by a listener who later in the programme remarked about the rise in taxi prices that 'this has become sort of a theme, hasn't it, brother Bram [the host]' (ini menjadi sedikit tema ini kan begitu, bli Bram).

This example confirms that hosts may have a steering role in deciding on the central topic of a 'Global terkini' broadcast, although their role is usu- 
ally restricted to inviting and introducing the listener-participants, asking questions and moderating the discussion by using phrases such as: 'Good afternoon. Who's this?' (Selamat siang. Dengan siapa?), 'Please, go ahead, Sir' (Silakan, Pak), 'So?' (Terus bagaimana?), 'Wait' (Sebentar), 'Two minutes left!' (Dua menit lagi!), 'Please keep it short' (Pendek ya), 'Thank you both' (Terima kasih, Anda berdua).

The host usually also assists the listeners in their attempts to 'discipline' themselves and their conversation partners by making meta-discursive comments on each other's radio performances. For instance, in an 11 July 2002 broadcast, a listener who was aware that a discussion had been going on for too long, tried to lead it to a conclusion by starting his own final argument with 'To make a long story short...' (Lebih singkat lagi...). In the same broadcast, a listener called Sujana and the host were joking about the formal or bureaucratic spiel of Mako by mimicking one of his phrases.

Kadek Mako: I would like to ask you, Mr Sujana. In this case...

Sujana [interrupting]: 'In this case, perhaps...'

Host [further mimicking]: 'In connection to this'. You haven't got the 'connection', the 'connection'... [laughter $]^{8}$

Another listener questioned the effectiveness of Global FM organizing onand off-air meetings between listeners and government and business officials by mimicking, in unison with the host, the speech behaviour of the latter.

Listener (L): But their answers are just like this: 'Yeah, your question is very good, later I will...'

Host (H): 'Take further measures...'

L: 'Later [I will]...'

H: 'Wait for instructions...'

L: 'Wait for instructions...'

The plesetan style of the previous two dialogues can be seen as a strategy of the talk show participants to break with the legacy of the monological, distanced style of official New Order culture. In Bakhtinian terms, their act

8 Kadek Mako: Mau bertanya dulu, Pak Sujana. Dalam hal ini ya...

Pak Sujana: 'Dalam hal ini barangkali', gitu...

Host: 'Dalam kaitan dengan hal ini', gitu. 'Kaitannya' toh nggak ada, 'kaitannya'... (Jurriëns, transcription of an 11-7-2002 broadcast.)

9 Listener (L): Tapi jawabannya cuma begini: 'Ya, pertanyaan Anda bagus sekali, nanti saya akan...'

Host (H): 'Tindak lanjuti...'

L: 'Nanti...'

H: 'Menunggu petunjuk...'

L: 'Menunggu petunjuk...' (Jurriëns, transcription of an 11-7-2002 broadcast.) 
of mimicking the speech of others, and imagining the persons of authority behind the discourse, are crucial steps in building ideological awareness and thus liberating oneself through dialogue.

While creatively stylizing upon and experimenting with another's discourse, we attempt to guess, to imagine, how a person with authority might conduct himself in the given circumstances, the light he would cast on them with his discourse. In such experimental guesswork the image of the speaking person and his discourse become the object of creative, artistic imagination. This process - experimenting by turning persuasive discourse into speaking persons - becomes especially important in those cases where a struggle against such images has already begun, where someone is striving to liberate himself from the influence of such an image and its discourse by means of objectification, or is striving to expose the limitations of both image and discourse. (Bakhtin 1981:347-8.)

The second of the dialogues analysed above was part of a conversation about Global FM's 'Jumpa pendengar' ('Meeting with the listeners') event, which was to take place a few days later, on 14 July 2002. 'Jumpa pendengar' is an annual off-air activity in which Global FM listeners can meet each other as well as Global FM crew and representatives of the local government and other institutions. They can express their concern about matters related to Denpasar and Bali, ask the official representatives to take responsibility for their deeds, and criticize and make suggestions for the improvement of the programme contents and broadcast styles of Global FM. ${ }^{10}$ In the 'Global terkini' conversation, the host explained the purpose of the 'Jumpa pendengar' meeting by responding to a listener's question on the criteria of participation.

In essence, it means that you can hold a dialogue with Radio Global as your allday-long friend. This also implies that you can give input, suggestions and criticism, either constructive criticism or fierce constructive criticism. Or [that there is space for] those of you who want to hold dialogues with each other as friends. We also invite the institutions involved in these matters, including members of parliament, since they are seated in that representatives' house. ${ }^{11}$

10 Carol Warren (1998:239) observed that as early as the first half of the 1990s the Bali Post newspaper organized 'seminars', which usually took place 'in a contentious atmosphere in which invited academics, government officials and prominent (sometimes notoriously outspoken) public figures felt prompted to make informative, even provocative, statements', and which 'developed into a vehicle for focusing attention on controversial local issues, with a popular style of reportage that took a long-standing relationship between bureaucracy, academia and the local media in new directions'. The newspaper also had a column 'Giliran anda' ('Your turn'), 'inviting public response on topical themes of serious import' (Warren 1998:239). The seminars and the column can be seen as the predecessors of the talk-back opportunities in Bali Post Group's current print- and audio-visual media and social activities, including 'Global terkini' (radio), 'Tanggapan Bali terkini' (newspaper) and 'Jumpa pendengar' (off-air).

11 Pada intinya isinya adalah berdialog dengan Radio Global sebagai teman Anda keseharian. Jadi di sini termasuk juga Anda bisa memberikan masukan, saran dan kritik. Baik itu yang kritik 


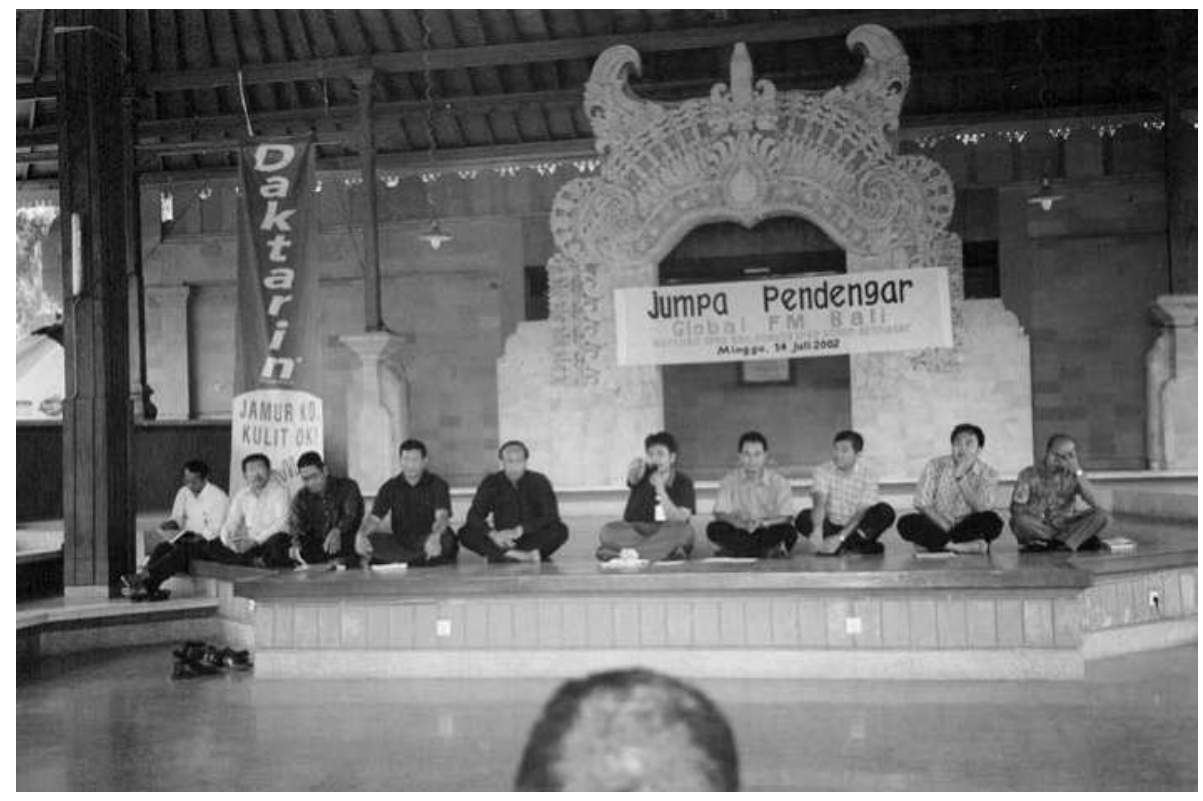

The Global FM invites the audience for discussion during the 2002 'Jumpa pendengar' event

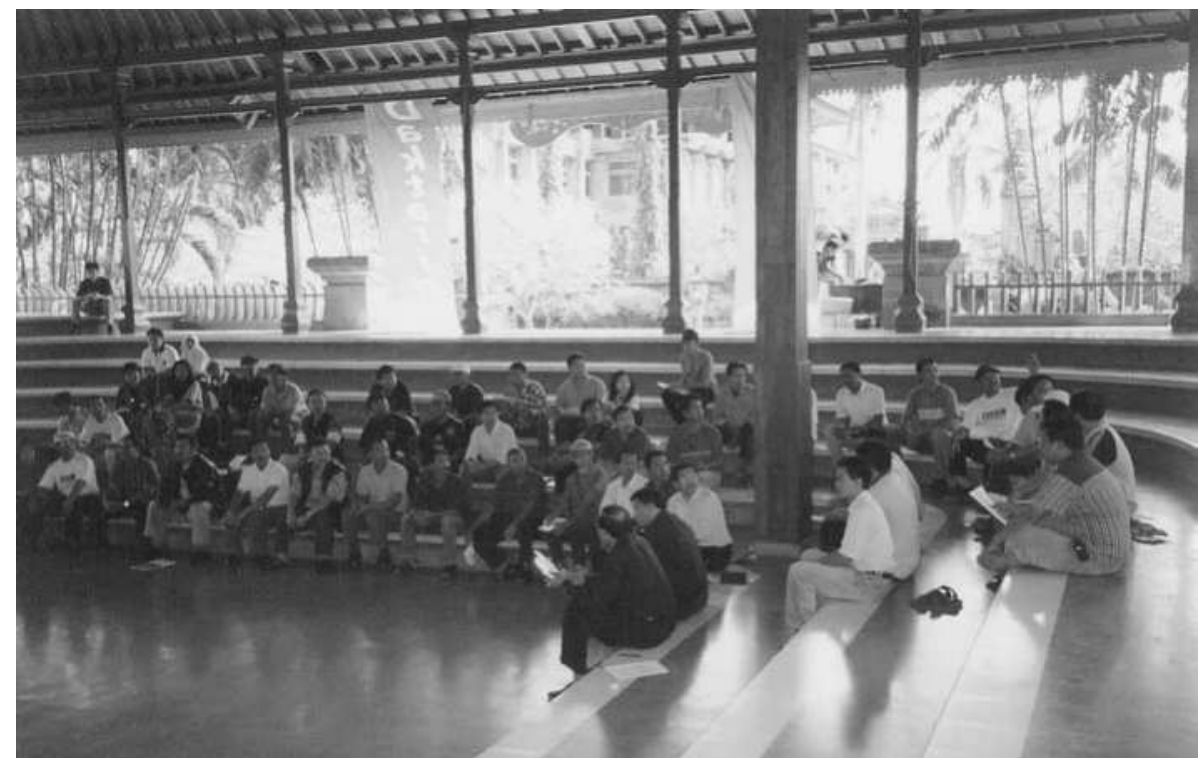

The audience participating in Global FM's 2002 'Jumpa pendengar' event 
The earlier quoted listener-participant Sujana, speaking to a second listener-participant and the host, gave his own criteria for participating in the event, which were similar to the Habermasian criteria for rational-critical debate, such as the selection of topics and the quality of debate. By taking a critical stand on 'Jumpa pendengar' - an event meant to raise critical debate - Sujana positioned himself as a listener-participant with a critical approach to the institution that in fact facilitated the on-air discussion he was involved in: Global FM. In a demonstration of liberalism and tolerance in emblematic Reformasi style, the host was open to his critical approach, even though the participant may not be attending the meeting, and stressed the authenticity of voice or character.

Sujana: See you on the 14th, if I have the time. [...] If it is just to 'say hello' and to drink tea, it would only seem to be a waste of time. If we can discuss the issue of the Java-Bali bridge, the casino, the Kuta Galeria, I will have the courage to waste time. But if I were to go there, only, say, to have a taste of tea, forget it... [...]

Other listener: When we have a break, when there is some spare time, I will accompany you [in order for us] to have a dialogue of high standard about anything you want. Please come.

Sujana: What is important is the quality. If people dare to buy a Mercedes only to show off their prestige, why shouldn't I dare to spend one day of deposit to go there? [...]

Host: Whether you come or not, the main thing is that you are who you are. Thank you, Sir. [followed by a jingle of 'Jumpa pendengar'] ${ }^{12}$

The different dialogues discussed in this paragraph demonstrate that the course of debate and the conclusion to be reached in 'Global terkini' are not drafted beforehand. Listeners are offered the opportunity to provide their own topics for discussion, perform the roles of host or experts, and give metadiscursive comments on discussion themes, speech styles and the effectiveness of discussions. In this sense, the activities and ideals of Global FM and

yang membangun, pedas yang membangun, atau Anda yang ingin berdialog dengan kawan satu dengan kawan yang lainnya. Instansi terkait dalam hal ini juga kita undang, termasuk anggota DPR sebagai yang punya rumah wakilan itu toh. (Jurriëns, transcription of an 11-7-2002 broadcast.)

12 Sujana: Sampai jumpa tanggal 14, kalau ada waktu. [...] Kalau sekedar 'say hello' dan minum teh itu kayaknya buang percuma waktu. Nanti bisa berdebat masalah jembatan JawaBali, berdebat masalah kasino, masalah Kuta Galeria, saya berani buang waktu. Tapi kalau cuman, ya, ke sana nyicipin teh, gitu aja... [...]

Other listener: Pada saat kita istirahat, pada saat ada waktu luang saya akan temani Anda mutu berdialog apa saja, gitu lho. Silakan datang.

Sujana: Yang penting kwalitasnya. Orang berani beli Mercy sekedar untuk menunjukan prestise, kenapa saya tidak berani mengeluarkan setoran sehari untuk datang ke sana, kan begitu. [...] Host: Jadi datang tidak datang, pokoknya Anda yang menjadi diri Anda. Terima kasih ya, Pak (Jurriëns, transcription of an 11-7-2002 broadcast). 
other Indonesian interactive radio share characteristics with an alternative, so-called oppositional public sphere rather than Habermas' bourgeois public sphere (Livingstone and Lunt 1994:32). According to Livingstone and Lunt (1994:24), the oppositional public sphere - unlike the bourgeois public sphere - emphasizes and makes public the potentially conflict-ridden process rather than the results of discursive opinion formation.

In Habermas's theory, one gets the impression of politics as a complex, emergent process where discussion, debates and negotiations take place in private (in families, committee rooms and the meetings of special interest groups) only coming to the light of critical exposure when they have been formulated clearly and in controlled forms of debate. Participatory programming brings public exposure earlier in this process. Ideas and opinions don't have to be 'well formed' before they can be expressed. (Livingstone and Lunt 1994:24.)

The fact that Global FM and also other Indonesian interactive radio stress the process rather than product of discursive opinion formation can be seen as an expression of the euphoria of freedom of speech and information as well as a sign of the early stage of the development of Indonesian radio journalism. Although it may not always be the result of deliberate concepts and actions like in Global FM's case, this alternative type of public opinion formation caters for some of the disadvantages of the conventional public sphere, such as its restricted accessibility and its distancing of specialist knowledge from the life world.

\section{Contests for listeners; Awarding 'Social empowerment personalities'}

As mentioned before, listener-participants can be nominated as 'Social empowerment personalities' for their contribution to Global FM talk shows and Balinese society at large. The nomination process forms another Global FM forum for the negotiation of the rules of interactive discourse, besides other forums such as the 'Global terkini' programme and the 'Jumpa pendengar' event. In order to be nominated, participants have to fulfil the following six criteria: 1 . Their integrity should be uncontested both on air and in society, 2. They should provide information that fits the topic of discussion, 3. They have to be active, regular participants in on-air discussions, 4 . Their opinions should deal with matters of public interest, and not private matters, 5 . They should be thought-provoking for the other listener-participants, and 6. They can only receive one award (Global FM 2002:9).

In accordance with Global FM's slogans, the nominees should not only be active and constructive participants in talk shows, but should also adhere to the ethics of radio discourse. In the case of Global FM this means that listeners 
have to think and speak clearly and control their temper. Listener-participants should not use the radio station as a medium to promote themselves, to express personal irritation and anger, or to refer to matters negatively related to SARA. They should discuss problems of public interest, although the Global FM crew understands that it is not always easy to distinguish private from public affairs, as private matters may have public relevance and public matters a restricted, personal impact. ${ }^{13}$

These criteria which cover on-air interactivity determine the representativeness of the people elected, or the sense in which their commentary is supposed to stand for the thoughts and feelings of the greater community of 'Balinese society' or 'the common people' (rakyat). Regardless of the nature of the criteria of their representativeness, these spokesmen or women are part of the rakyat themselves, which is a clear break from what James Siegel (2001:63) calls 'the mythology of political authority' of the New Order.

The myth is that only political authority and only that particular political authority would do. It is just there that one sees one of the great crimes of the New Order: it left intact, pristinely unchanged, the idea of 'the people', whether under the name rakyat or massa, as speechless and needing leadership to speak for it. It is as though the only authority possible existed necessarily outside 'the people' themselves and resided in those who constituted themselves as their leaders. The myth is that whenever the people attempted to speak for themselves, they were the massa, the mob. (Siegel 2001:63.)

It is the resistance against this mythology that constitutes one of the main reasons for the enormous popularity of interactive talk shows on radio and television during the late New Order and early Reformasi. It is also against this background that Global FM's urge to organize a competition for 'Social empowerment personalities' can be understood. While the competition serves the radio station's commercial interests, it is also designed to involve civil society and improve the quality of public discourse, similar to Friedrich Naumann Stiftung's competitions for radio stations and unlike New Order's use of contests to exercise control and implement monologism (Jurriëns 2006).

Each year on 30 May, the station's anniversary, Global FM publishes a magazine in which the ten listeners awarded the title are listed and interviewed. The interviews contain rich information about the popularity and accessibility of Global FM, the negotiation of the rules of radio discourse

13 As an example of the first case, the Global FM brochure (2001:19) mentioned a mother dealing with her child having problems at school, thereby supporting other mothers and making suggestions for the improvement of the education system. An example of the second case was somebody complaining about public electricity provision in general, while the problem in reality only concerned a lack of electric light in his own house. 
among listeners, the process of becoming a radio personality, gender issues, intimidation by other listeners or officials, off-air organization among listeners, and intermediality. The lists of the winning listeners for 2001 and 2002 consisted of those with educational backgrounds ranging from junior high school to university and included housewives, teachers, taxi drivers, traders and government officials. These lists are representative of the audience's diversity in profession and social or economic status. Some of the awarded listeners complained, however, that Global FM had not made enough efforts to address youth explicitly.

In general, there were four ways in which the awarded listeners first came into contact with Global FM: 1. By unintentionally listening to the radio programme, 2. By reading the reports of Global FM's talk shows in Bali Post or Den Post, 3. By noticing Global FM's advertisements, and 4. By talking to friends or relatives. Most had listened for some time to the talk shows and other programmes before actively participating in interactive discussions. Some found it difficult to participate regularly as they could not afford the telephone costs or had problems in assessing the Global FM telephone lines, which were almost always busy. Some listeners pleaded for a free phone service in which the radio station would bear the telephone costs, or an SMSservice (text messaging) in which listeners could participate at a low cost at any time. Most listeners had to learn how to speak in public, and how to adapt themselves to radio speech in general and the discursive behaviour of the hosts and other listeners in particular. For them, being on air was an exercise in controlling their emotions, distinguishing between major and minor problems, identifying and respecting other people as well as introducing and developing their own identities.

The following two quotes from two 2001 'Social empowerment personalities' reflecting on their participation in interactive radio communications are concrete illustrations of a Bakhtinian process of ideological becoming through dialogue. The first quote is from an interview with a trader, the earlier mentioned Mako.

From the beginning, I was against injustice. I often read the magazines Forum and Tempo, which covered injustice in Indonesia. Eventually I became incited [to know] where I could ignite my ideas and pour out my feelings. In fact, before this medium of Global [FM], there were no other media in which I could speak out loud. That means that I only talked with friends around. Eventually there was the medium of Global. I listened to it several times, and there were several billboards of radio Global put up along the roadside. The first time I tried to enter was in Warung Global. If I am not mistaken it was Mr Hendra who responded that time, while I was speaking my sentences with a trembling voice, because I was not used to talking on the radio. [...]

About talking on the radio, I believe that some Global companions who join 
talking for the first time can be rough. Nevertheless, that is a process in which people teach themselves by entering Global several times. When I had just entered, I was expressing things too vulgarly myself. After several months, I asked myself why I did it that way, why I did not say things in a refined but effective way? For instance, conflicts among Global companions should best be finished in private, that is, among the two of them. Otherwise we would be talking about reform and democracy without being able to implement those things. We also have to leave aside [self-] interests when we enter Global. For instance, party concerns or functional interests. It is our priority to voice the aspirations of the people. ${ }^{14}$

Mako's own experience of participating in talk-back radio clearly mirrored the development of Global FM's interactivity concept as reflected in the use of different slogans over different periods of time. Mako was 'willing to talk' from the very beginning, but had to 'improve his talk' and learn that there were 'moments to listen' and 'moments to speak' and, for that matter, 'moments to act'. He represented a Habermasian idea of the public sphere, by stating that communication had to be effective and people had to express 'the aspirations of the people' (aspirasi masyarakat), not their private interests. Moreover, he thought that conflicts should be restricted to the private sphere, thereby implying that the public sphere should be reserved for consensus, as in the classical bourgeois public sphere.

The second quote is from an interview with a civil servant, Agus Bambang Priyanto, who also reflected on his own development as a speaking subject and social actor throughout his participation in radio dialogue. Priyanto reported that he became accepted and popular among the other Global FM listeners, particularly when his on-air personality began to coalesce with his off-air personality.

14 Saya dari dulu anti dengan ketidakadilan. Saya sering membaca majalah Forum dan Tempo yang memuat ketidakadilan di Indonesia. Akhirnya saya tergelitik, di mana bisa mencetuskan ide dan menuangkan perasaan saya. Kebetulan sebelum ada media Global ini, di media-media yang lain tidak bisa bicara lantang. Artinya saya hanya bicara dengan teman sekitar. Akhirnya ada media Global. Beberapa kali saya mendengarkan dan ada beberapa billboard radio Global yang terpampang di jalan. Saya coba masuk pertama kali di Warung Global. Waktu itu kalau tidak salah diterima pak Hendra, dengan kalimat yang gemetaran karena tidak biasa ngomong di radio. [...]

Soal bicara di radio, menurut saya kalau kawan Global pertama kali ikut bicara mungkin ada yang kasar. Namun demikian itu proses pembelajaran diri dengan beberapa kali masuk ke Global. Saya sendiri ketika baru masuk terlalu vulgar menyatakan sesuatu. Setelah beberapa bulan saya introspeksi diri kenapa demikian, mengapa tidak mengatakan secara halus tapi mengena? Umpama kalau ada pertentangan di antara kawan Global sebaiknya diselesaikan secara person artinya berdua. Agar tidak kita bicara reformasi dan demokrasi ternyata kita tidak bisa mempraktekkannya. Selain itu kita masuk Global harus menanggalkan kepentingan. Misalnya masalah partai atau kepentingan jabatan. Kita utamakan untuk menyuarakan aspirasi masyarakat (Global FM 2001:17). 
Initially I was rather scared to talk at Global [FM]. I observed they were very critical and fierce. Would I be able to follow their criticism and pace? I followed for almost six months, and then, last December, in 2000, I tried to enter 'Bali terkini', I tried something short while adapting myself and studying the characters of the others. When I joined broadcasts from December [2000] until February 2001, people had difficulties in identifying me. Who is Mr Haji Bambang, Mr Haji Bondres? When after a while my character was discovered by somebody who knew, eventually my mask was taken off. This disclosure led to people calling me at home during the day as well as in the evening. ${ }^{15}$

Other participants deliberately use nicknames during interactive talk shows to give extra allure to their radio performance or to keep their on- and off-air personalities strictly separate. Joshua Barker (2003:391-2) has observed the same phenomenon in the case of interkom ('intercom') in West Java, in which participants use 'on-air names' (nama udara) to be distinguished from their 'on-land names' (nama darat). In both interkom and commercial radio, the use of nicknames is often a prerequisite for self-expression, by which people allow themselves to play a role they could never play in daily life, either under the spotlight of potential stardom or the safe guise of anonymity. ${ }^{16}$

An example of the first type of nickname users in Global FM broadcasts is a listener and 2002 'Social empowerment personality' with the birth name of I Gusti Ngurah Artawa, who decided to call himself Ngurah Kapah ('Trembling Ngurah') on air, referring to the fact that his hand shook holding the phone each time he tried to join one of the busy Global FM talk show lines (Global

15 Saya agak takut awalnya berbicara di Global. Saya amati kritis-kritis sekali dan galak-galak. Apakah saya mampu mengikuti kekritisan dan kiprah mereka? Hampir 6 bulan saya ikuti, lalu mulailah bulan Desember tahun 2000 kemarin saya mencoba untuk masuk di 'Bali Terkini', coba yang pendek sambil menyesuaikan diri dan mempelajari karakter teman-teman yang lain. Saya siaran mulai Desember sampai Februari 2001 orang sulit mengidentifikasi saya. Siapa sih pak Haji Bambang, pak Haji Bondres. Setelah lama-lama karakter saya dibaca satu orang tahu akhirnya terbongkarlah kedok saya. Keterbongkaran ini akhirnya merembet dengan telepon di rumah baik siang maupun malam (Global FM 2001:19).

16 See also Arps 2003:307-8. Interkom is 'a local invention, a product of Indonesia's informal economy. In a technical sense, it could be viewed as the homemade analogue of a telephone party line. But in cultural terms, it bears greater resemblance to a Citizen Band radio: it is a network where people can chat, listen to music, pass on messages, and exchange information' (Barker 2003:385). In the latter sense, it also bears much resemblance to community radio (Jurriëns 2003).

Although interkom has different aims and a much smaller scope than Global FM's news broadcasts, another interesting similarity between the two - apart from the prevalence of nicknames is that listener-participants are involved in the activity of 'disciplining' each other: 'Conversations on interkom can be quite vulgar and coarse, so sometimes members of a line may decide to set up a line that is more polite and refined. People who want to join the new line will have to agree to abide by the discursive conventions. Those who do not abide by the rules risk being disconnected' (Barker 2003:386). 
FM 2002:10-1). Another example is a person and also 2002 'Social empowerment personality' called Putu Gede Suarta, who uses the radio name Sadam Bali Timur (sic, 'The Saddam of East Bali'). Suarta gained this nickname from his friends and colleagues, who felt that his moustache resembled that of Saddam Hussein, the former president of Iraq. ${ }^{17}$

While these participants use nicknames for fun, for others it is a matter of safety. It is not unusual for active participants of on-air discussions to receive telpon gelap or surat kaleng (anonymous, threatening phone calls or letters, respectively) from discontented fellow listener-participants, for whom Global FM's paradigm of careful speaking, listening and acting apparently does not appeal. These experiences confirm that in times of reform restrictions on the freedom of expression often originate from individuals and groups in civil society rather than the state apparatus. Women especially find it hard to express their opinions freely and find acceptance as public figures, as the following quote from an interview with Maria Christina Sri Wiji Utami, housewife and 'Social empowerment personality' 2001, illustrates.

I consider the problem that few women join in having opinions on the radio as a result of the fact that in our culture there is still much 'under estimate' [ sic, in English] by men that causes women to have feelings of inferiority. I regret this very much and I am still in the stage of struggling for a manner for women to have the strong self-confidence that they are not less than men [and that] they can be treated as equals, especially in having opinions, thinking and everything. Let us speak, because it is of the same value as men [speaking]. ${ }^{18}$

Utami's experiences are shared by another female 2001 'Social empowerment personality' with the radio name of Ipung Sapura, who in her daily life is a business employee. Sapura's wonderful final sentence makes it clear that engagement in on-air dialogue enables her to give expression to her own thoughts and feelings, sharpen her ideological awareness and further develop her identity.

The reactions of other listeners to the opinions that I give on the radio vary considerably. There are also people who say: 'Don't join talking every day, Pung,

17 Global FM 2002:11-2. Also in this case I believe the use of nicknames constitutes a means of creative and liberal self-expression - in line with the idea behind Global FM's talk shows as well as the spirit of Reformasi - even if it has to be noted that the nickname has to do with the man's appearance and nothing with his political commitments.

18 Soal sedikitnya wanita yang ikut beropini di radio saya menilai dalam budaya kita masih banyak ditanamkan under estimate [sic] dari laki-laki yang menimbulkan rasa minder pihak perempuan. Saya sangat menyesalkan hal ini dan saya masih dalam taraf memperjuangkan bagaimana agar kaum saya punya rasa percaya diri yang kuat bahwa mereka tidak di bawah laki-laki terutama dalam beropini, berfikir dan segala hal mereka bisa disetarakan. Marilah kita bersuara, karena nilainya sama dengan kaum laki-laki (Global FM 2001:17). 
otherwise your talk will become stale'. To be honest, these words are stale, because I want to speak in order to support women. Speak! Speak, whenever you are able to, because we are not like women used to be. Once I received an anonymous phone call without any clear purpose. There are also people who are cursing, but these things will not prevent me from talking. I don't want to have followers. But I want the things that I say to have benefit. What I say is the reality of what I see, feel and hear. ${ }^{19}$

Conversely on-air communication does not necessarily lead to threats and intimidation, but to mutual solidarity and common initiatives. For instance, several Global FM listeners founded Forum Bali Peduli (the 'Bali Cares Forum'), which is meant to signal problems in Balinese society and function as an intermediary between the people and the regional and national governments (Global FM 2001:18).

Global FM listeners estimate that the authorities respond to between 30 and 80 per cent of the issues they raise. Some listeners are not impressed by this outcome, as they believe there are still many officials who do not make the effort to listen to the radio or read the listeners' comments in the newspapers. They suggest that Global FM or an independent body should write letters with all the complaints and ideas of the listeners directly to the institutions involved (Global FM 2001:17). One of them is Mako, who underlines the potential of radio discourse for social and political action but is not entirely satisfied with the results achieved so far.

In the era of reform, it is not surprising at all that there is a medium like this [Global FM], but I see that a characteristic of radio Global is that it has not been giving a voice to real [that is, ordinary] people yet. Maybe they are still reluctant. Nevertheless, radio Global has made a start, a very recent start though. The impact of radio Global broadcasting in Bali is quite good. There used to be a 'statement' [in English] in Balinese society that we were 'unwilling to talk' [in Balinese], although I as a Balinese was actually not 'unwilling to talk'. In every radio programme, I always invited other listeners who were still passive, and as it turned out there were members of society who responded to my call. I mean, in comparison with last year there has been a tremendous development.

I direct my hope especially to the legislators; they should respond to the aspirations of society. In Bali, PDI-P won 80 per cent of the votes, but until now they have

19 Tanggapan pendengar lain atas opini di radio yang saya sampaikan cukup beragam. Ada pula orang yang mengatakan: 'Jangan tiap hari ikut berbicara Pung, nanti basi'. Terus terang kata-kata ini basi karena saya kepengin berbicara untuk memberikan support pada kaum saya. Berbicaralah! Kapan pun anda sempat, karena kita ini bukan seperti wanita yang seperti dulu. Saya pernah menerima telpon gelap yang tidak tentu tujuannya. Ada pula yang mencaci-maki tapi hal itu tidak akan membuat saya berhenti berbicara. Saya tidak ingin punya pengikut. Tapi saya ingin apa yang saya katakan untuk kebaikan. Apa yang saya katakan itulah kenyataan yang saya lihat, saya rasakan dan dengar (Global FM 2001:18). 
responded to only one per cent of the people's aspirations. The executives, especially in Gianyar, are rather slow in reacting to the problems that have been raised by radio Global. Maybe because they still think according to the old pattern. I want them to listen more intensively to radio Global. I watch closely whether what they - the institutions - do refer to the things that are said on radio Global. ${ }^{20}$

Both on and off air, Global FM listeners have demonstrated great self-confidence, considering themselves as nara sumber (expert informants on current affairs), members of the 'regional street parliament' (DPR-D Jalanan) or even potential members of the real regional parliament (DPR-D). These listeners view themselves as the exponents of the Reformasi ideals construed to involve transparency, accessibility and negotiation, and regard both news provision and politics as public property and not an elite preserve. As the following chapter will demonstrate, the people involved in community radio - while adhering to the same ideals as the Global FM listeners - go even one step further, by not only allowing public involvement in news production, but also media ownership and management.

20 Di era reformasi memang tidak aneh ada media seperti ini, tetapi saya melihat kekhasan radio Global belum menyuarakan masyarakat yang sebenarnya. Mungkin mereka masih malumalu. Namun demikian radio Global telah mendahului walaupun dalam umur yang sangat muda. Dampak dari radio Global ini mengudara di Bali cukup bagus. Kalau dulu ada statement di masyarakat orang Bali itu 'koh ngomong', saya sebagai orang Bali sebenarnya tidak 'koh ngomong'. Dalam setiap acara di radio saya selalu mengundang pendengar lain yang masih pasif dan ternyata direspon masyarakat. Artinya kalau dibandingkan tahun lalu, ada perkembangan yang luar biasa.

Harapan saya terutama untuk pihak legislatif seharusnya merespon aspirasi masyarakat. Di Bali $80 \%$ suara dimenangkan adalah PDI-P, namun hingga saat ini mereka baru merespon aspirasi masyarakat $1 \%$. Pihak eksekutif, terutama di Gianyar agak lama merespon permasalahan yang dilontarkan di radio Global. Barangkali karena masih berpikiran dengan pola lama. Saya ingin mereka lebih intens mendengarkan radio Global. Saya amati apa yang mereka (instansi) lakukan itu mengacu seperti apa yang diomongkan di radio Global (Global FM 2001:17). 



\section{Chapter vili}

\section{Radio komunitas and the imagination of community}

In Indonesia, community radio (radio komunitas) developed as a 'Third Way' (Howell and Pearce 2001:65-8) alternative to government and commercial radio. ${ }^{1}$ After an intense struggle, community radio activists and practitioners found legal acceptance of their activities in Indonesia's Broadcasting Law of 2002. ${ }^{2}$ An important goal of community radio in Indonesia and elsewhere is to enhance people's self-awareness and their sense of belonging to a community.

The capability to create a sense of community is not the exclusive property of community radio and other 'community' media. Every type of medium, including government and commercial media, creates communal links between people through the process of communication. Nevertheless, by distinguishing itself from other media that do not explicitly designate the aspect of community, community radio embodies specific visions of communications and society, thereby confirming Benedict Anderson's (1991:6) phrase that 'communities are to be distinguished, not by their falsity/genuineness, but by the style in which they are imagined'.

Community radio is known as radio 'for, about and by the people', which indicates that the listeners bear responsibility for ownership, management and production (Fraser and Estrada 2001:6; Gazali 2002e:74). In that sense, community radio goes one step further than conventional media institutions in resisting the possible refeudalization of society by the government or the unbridled promotion of consumerism by commercial ventures. The scope of community stations is small though, usually restricted to a village or one or several neighbourhoods in a town or city. This means that community radio cannot claim to represent society 'as a whole' and may serve and be domi-

1 This chapter is partly based on my article 'Radio komunitas di Indonesia; "new Brechtian theater" di era Reformasi?' (Jurriëns 2003).

2 The first Indonesian Broadcasting Law of 1997 only included governmental and commercial broadcasting organizations. 
nated by the specific interests of a local community or part thereof. On the other hand, community radio has the potential to provide a voice for people and special interest groups that have been excluded from the mainstream media.

This chapter will discuss two types of Indonesian community radio: one based on socio-geographical principles, and the other representing the interests of tertiary education students. I will compare the way in which these two forms of community radio create communal feelings with Walter Benjamin's theory of the mass media and Bertolt Brecht's ideas on theatre and radio. Benjamin and Brecht were linked to the Frankfurter Schule of which Habermas is considered to be a late representative, and have influenced the ideas and practices of Indonesian community radio practitioners both directly and indirectly.

\section{Accessibility, participation, self-awareness}

Community radio developed against the specific historical and cultural backgrounds of different countries. Especially in many former European colonies in Africa and Asia, including Indonesia, it was difficult for people to establish community stations, as they were confronted with the colonial legacy of broadcasting systems that did not leave much room for activities outside of government control (Fraser and Estrada 2001:6-7).

The roots of the concept can be traced back to the activities of groups of miners in Bolivia and Colombia during the late 1940s, which used small-scale radio in order to unite themselves and strive for improvement of their working conditions. In Europe during the 1960s and 1970s, illegal radio stations that fought governmental broadcasting monopolies developed the current notion of 'radio for, about and by the people'. In Africa, community radio was introduced as a medium for democracy after the fall of the South African Apartheid regime. In Asia, international donor organizations such as UNESCO and, to a lesser extent, national broadcasting institutions have been involved in the promotion of community radio (Fraser and Estrada 2001:6).

According to the 2001 UNESCO Community radio handbook, community radio attempts to 'turn the audience into protagonists, by involving them in every aspect of management and programme production, and by providing them with programmes that help them with the development and social progress of their community' (Fraser and Estrada 2001:15). I will take this definition as a starting point, as UNESCO had great impact on the development of community radio in Indonesia. Since 2001, the Indonesian translation of the handbook (Buku panduan radio komunitas) has been presented at seminars and been used by local radio practitioners. 
The central themes of UNESCO's concept of community radio are accessibility and participation. 'Accessibility' here means that all community members should have equal opportunity to receive broadcasts, while 'participation' implies that every listener should have the chance to be actively involved in management and production. The community as a whole bears responsibility for the ownership, management and funding of their radio station. The community is also supposed to safeguard the editorial independence and credibility of the station, and represent the diverse interests of different sections in society, including minorities and marginal groups (Fraser and Estrada 2001:16-7).

According to UNESCO, the main functions of community radio are to: 1. Represent and support local culture and identity, 2. Create on-air debate and opinion, 3. Offer a variety of programmes, 4. Support democracy and open dialogue, 5. Stimulate development and social change, 6 . Promote civil society, 7. Represent the idea of good governance, 8 . Stimulate civil participation through information provision and innovation, 9. Provide the voiceless with a voice, 10. Function as a community telephone service, 11. Contribute to the diversity of ownership in broadcasting, and 12. Train and educate new broadcasters (Fraser and Estrada 2001:18-22).

UNESCO's paradigm on community radio establishes specific links between communications and community-building. It emphasizes that communication is an essential tool for people to participate in the development of their society. Community radio stimulates active participation of community members by providing them with forums for debate, analysis and the exchange of ideas and opinions. Such forums can generate communal points of view and result in collective action. UNESCO also points out that development 'cannot function when it is based on individual perceptions. What is needed is a collective perception of the local reality and thoughts about choices to improve it' (Fraser and Estrada 2001:19-20).

This means that this type of radio is supposed to create a sense of community not just because it engages people in collective communication - as would be the case in any type of mass media - but because it makes people aware of themselves as members of a social network. This awareness is also created in interactive programmes produced by commercial stations, such as Suara Surabaya's 'Kelana kota', Jakarta News FM's 'Features sang guru' or Global FM's 'Global terkini'. However, in community radio the opportunities for nurturing media awareness and Bakhtinian ideological becoming are extended beyond media interactivity in a purely discursive sense, as listeners are also offered a direct say in matters related to media ownership and management. 


\section{Aura and the everyday}

In order to further analyse the idea and practice of community radio in Indonesia and elsewhere, I will use Richard Middleton's (1990) analysis of three modes of mass-mediated culture: the auratic, the everyday and the critical. According to Middleton (1990:98, 250), the 'auratic mode' stimulates the audience's imaginary identification with the media presentation and representation it is confronted with, and confirms its sense of identity, totality and continuity. The 'everyday mode' creates a convivial atmosphere, stimulates audience participation, and establishes links between the audience and society at large. The 'critical mode' fractures the audience's sense of totality and continuity, and arouses feelings of protest through shock-effects and internal contradictions in the media presentation and representation.

Although Middleton uses these three modes specifically to analyse the social role of pop music, his model can be extended to the analysis of other media, including community radio. Community radio, based on the ideas of participation and self-awareness, reflects Middleton's categories of the everyday and the critical, and undermines the auratic. This is not to deny the strength of the auratic mode in creating community, but to confirm that community radio creates communal feelings in a different way than auraoriented media. I will focus on a category of 'auratic' media, so-called media events, in order to illustrate their difference with community radio. At the same time, I will argue that community radio does, paradoxically, produce 'nostalgia for aura'.

According to Dayan and Katz' (1992:4), media events include television broadcasts of such monumental events as the funeral of President Kennedy, the royal wedding of Prince Charles and Lady Diana, the Watergate hearings, the revolutionary changes in Eastern Europe in 1989 and the Olympic Games. Media events are interruptions of routine, transmitted live, organized outside the media, pre-planned, and presented with reverence and ceremony. They are proclaimed historic, applaud the voluntary action of great personalities, celebrate reconciliation, electrify very large audiences and institute a norm of viewing by which audiences actively celebrate the event. In this way, media events 'integrate societies in a collective heartbeat and evoke a renewal of loyalty to the society and its legitimate authority' (Dayan and Katz 1992:5-9).

Contrary to community radio, media events achieve social integration primarily through their ceremonial or auratic character. Due to the pioneering work of Walter Benjamin, 'aura' has obtained special meaning in the context of the mass media. In his work Das Kunstwerk im Zeitalter seiner technischen Reproduzierbarkeit ('The work of art in the age of its technical reproducibility'), Benjamin (1977:11-3,15) argues that the work of art used to derive its aura, or cult value, and authority from its authenticity and uniqueness. Authenticity 
implied the work of art's history and original entrenchment in ritual tradition. Uniqueness referred to the work of art being distant from and inaccessible to the audience in contemporary society (Benjamin 1977:12).

The possibility of technical reproduction deprived the work of art of its aura, as it replaced authenticity and uniqueness with instantaneousness and seriality (Benjamin 1977:15-6). Reproduction also created immediacy by disentangling the work of art from its original environment and relocating it in the world of the recipient. Figuratively, it moved the work of art from the ritual realm of tradition to the secular realm of politics (Benjamin 1977:13, 18). Although Benjamin deplored the work of art's loss of aura, at the same time he was positive about its increased accessibility (Middleton 1990:64).

While the contextual circumstances in which television or other mass media are received differ from the contextual circumstances of the live events that are represented, this does not mean that the mass media would not be able to produce their own type of ceremoniality. For instance, people often dress up, prepare special food and invite friends in anticipation of watching a media event on television (Dayan and Katz 1992:9, 13), thereby turning the living room or any other location where the event is watched into a ceremonial place with the auratic features of authenticity and uniqueness. Thus the question of whether media events are manifestations of 'true' or 'false' aura (Middleton 1990:66) should be subordinated to the recognition of the specific performative qualities of the events (Auslander 1999:44). As Dayan and Katz (1992:78) rightly argue

the televising of public occasions must meet the challenge not only of representing the event, but of offering the viewer a functional equivalent of the festive experience. By superimposing its own performance on the performance as organized, by displaying its reactions to the reaction of the spectators, by proposing to compensate viewers for the direct participation of which they are deprived, television becomes the primary performer in the enactment of public ceremonies. Such performances by television must not be considered mere 'alterations' or 'additions' to the original. Rather, they should be perceived as qualitative transformations of the very nature of public events. (Dayan and Katz 1992:78.)

Dayan and Katz (1992:19) mention several factors that prevent media events from becoming mere tools for political manipulation and propaganda. They argue that broadcasters, as long as they are not directly controlled by the establishment, can refuse a government proposal to mount an event. The event will not succeed either if the audience shows its disapproval. Moreover, people normally view the media event in a context - at home, with friends - that is unlikely to translate aroused emotion directly into political action. Audiences also produce oppositional readings of media events, thereby reducing the manipulative potential of these events. 
Nevertheless, the festive character of media events, as well as its entrenchment in the world of politics, could indeed evoke unpleasant associations with the mass rallies of fascism or the staged events of communist regimes, and lead to a Benjaminian fear of 'the aestheticization of politics' (1977:42) or a Habermasian fear of the refeudalization of the public sphere. Partly subscribing to these fears, I believe that media expressions with a strong auratic appeal such as media events, ask for a stricter check on hegemonic abuse than media expressions dominated by the everyday or critical modes, such as the majority of programmes on Indonesian community radio.

\section{Community radio in Central Java}

As mentioned before, in general two types of community radio can be found in Indonesia: community radio based on socio-geographical principles and campus radio. 'Socio-geographical' community radio is for, about and by people whose mutual social relationships are determined by the fact that they live in the same geographical or administrative area or share the same professional background. The managers, producers and target audiences of campus radio are university students or students from other tertiary educational institutions. In spite of their limited cover areas and small communities, both types of community radio - as concepts as well as practices - are not strictly local affairs, as they have precedents in other countries and entertain links with national and international organizations. For instance, many Indonesian community stations receive educational or financial support from international organizations such as UNESCO and The Ford Foundation. ${ }^{3}$

I will focus on community radio in Central Java, the region with the highest proliferation of community stations in Indonesia. In Central Java, socio-geographical community stations and campus stations each stress different aspects of community radio. Socio-geographical community stations conceive radio primarily as a medium to improve local society and focus on accessibility to and participation of the listeners. They use cheap and simple communication technologies and broadcast messages that can be easily understood by everyone in the community. During broadcasts, hosts and listeners share experiences about their work, family, and other aspects of 
daily life. In terms of Benjamin and Middleton, this type of community radio has a 'low' auratic mode and a 'high' everyday mode. Campus stations in Central Java, particularly Yogyakarta, also discuss daily life, that is, the life of students. The students self-consciously present their stations as alternatives to commercial radio and public radio and actively explore the idea of community radio and its position in Indonesian media history. I argue that their interests also include 'nostalgia for aura' and a romanticizing of campus life.

Two socio-geographical community stations that were represented during the UNESCO community radio seminar in Yogyakarta, September 2001, were Angkringan ('The Food-Vendor's Place', a food stall were people come to eat and talk with each other) and Suara Petani Klaten ('The Voice of the Farmers from Klaten'). Angkringan was founded in 2000 by the inhabitants of the Timbulharjo village. Before they founded the radio station, the Timbulharjo people already had a community magazine, also called Angkringan. The community used the magazine and the radio station not only to have easier access to information, but also to represent, organize and mobilize itself. According to the people involved, the new communication media helped the community to reintegrate and have stricter control over the policies and activities of the village government (Akhmad Nasir 2001:1-2).

The radio station did not replace the magazine, but was supposed to compensate for some of its disadvantages. The two main disadvantages were that people had to spend money in order to purchase the magazine, and be literate in order to understand it. The Angkringan radio programmes, on the other hand, were on air for free, had an oral character and could report about events and respond to people's reactions more frequently and efficiently than the print medium (Akhmad Nasir 2001:2-3). In other words, the radio station provided the inhabitants of Timbulharjo with broader access to information and enabled them to participate actively in radio management and programme production. According to the Angkringan people, this type of participation enhanced the villagers' feeling of togetherness and sense of community.

Radio Angkringan broadcasts daily from 6 p.m. until midnight. This evening schedule enables farmers, students and others to listen and contribute to programmes after returning home from their daily activities. Programmes include campursari and dangdut popular music, ${ }^{4}$ news and talk shows. The news programmes contain information from the Angkringan magazine, local newspapers, the Internet, television and other radio stations. The radio station covers its operational costs by broadcasting commercials for local products and selling coupons for requesting songs and sending on-air greetings.

4 Both genres are very popular in Central Java and often used in contemporary wayang kulit (shadow puppet) performances, among others, see J. Mrázek 1999:46-70. 


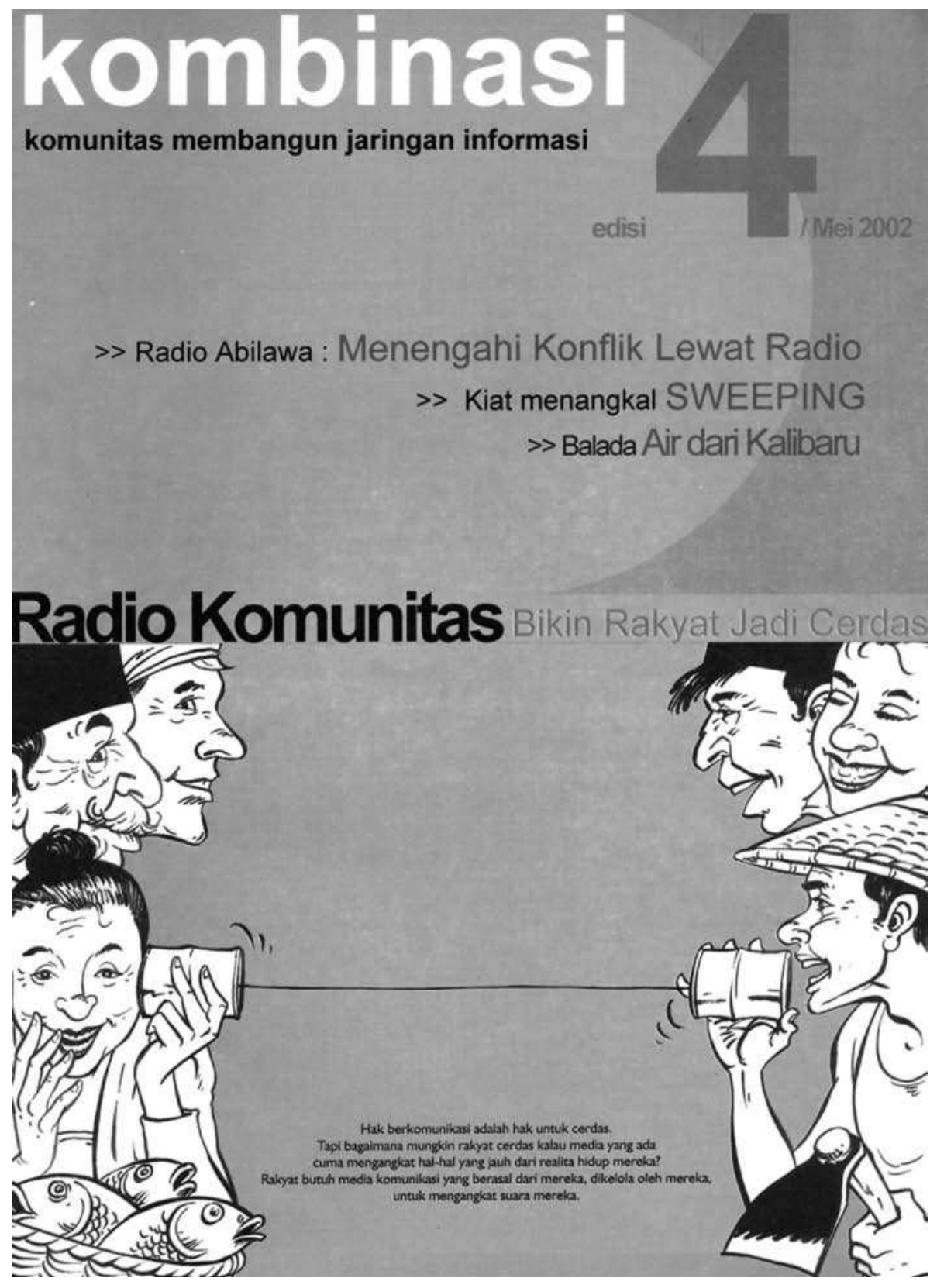

A Combine Resource Institution journal (May 2002) promoting two-way communication and the slogan 'Community radio makes the people become clever' (Radio komunitas bikin rakyat jadi cerdas) 
In line with the predicament of community radio, Angkringan makes use of cheap and simple production and broadcasting equipment. The radio station's equipment includes a computer, tape recorder, antenna and microphone. Part of this equipment was borrowed from individual households in Timbulharjo. With money from ISAI, Radio Angkringan could replace its initial 15-watt transmitter with a 20-watt transmitter with a reach of four to five kilometers (Akhmad Nasir 2001:3-5).

Suara Petani Klaten was founded with the help of the local NGOs Insist and Combine Resource Institution (CRI) in the village of Klaten, early 2001. Like the people from Timbulharjo, the Klaten community first used a magazine and later a radio station for self-expression and self-representation. Unlike Angkringan, Suara Petani Klaten focuses exclusively on farmers.

Antonius M. Indrianto, one of the pioneers of Suara Petani Klaten, uses the slogan 'Sekali di udara, lebih banyak di lapangan!' ('On the air once, in the field more often!') in his writings and other activities related to the radio station. ${ }^{5}$ This slogan means that people need to be much 'in the field' and have in-depth knowledge of their village in order to be able to produce programmes capable of representing and mobilizing their fellow community members. Suara Petani Klaten broadcasts campur sari music, local art performances and information about farming, among others. Similar to Angkringan, the radio station covers its operational costs by selling coupons for requesting songs or sending on-air greetings. The listeners can also write comments and suggestions on these coupons, which function as indices of the radio station's popularity and viability (Antonius M. Indrianto 2001).

\section{Campus radio in Yogyakarta}

Campus radio focuses on students at universities and other educational institutions, although it may also involve people from the wider community. Similar to socio-geographical community radio, campus radio uses radio as a medium for social improvement. However, while the former's main concern is serving the public cause, the latter often also provides reflection upon radio's position in media theory and history, and its potential for Brechtian 'refunctioning' and 'alienation'.

The campus stations in Yogyakarta are all involved in Forum Radio Kampus Indonesia (FORAKI, Indonesian Campus Radio Forum), a communication network for campus radio. During regular meetings and e-mail dis-

5 This is a parody on Radio Republik Indonesia's (RRI) patriotic slogan: 'Sekali di udara, tetap di udara!' ('Once on the air, on the air forever!'), which traces RRI's origins back to the important role radio played in Indonesia's struggle for independence. 
cussions, the forum members deal with topics related to community radio in general and campus radio in particular. They try to find answers to problems ranging from enhancing broadcasting skills to obtaining official frequencies.

The last problem in particular has captured the attention of community radio practitioners. Radio stations only have a right to a permanent spot on the air when they have a legal status. However, it is almost impossible for community stations to find the money to register as a legal institution, unless they decide to become commercial. Some activists have argued that one frequency in the Indonesian radio spectrum should be reserved specifically for community radio. As they have a limited reach and do not easily interfere with each other's broadcasting area, community stations could use this frequency jointly (Akhmad Nasir 2001:6).

Swaragama is a campus station that decided to engage in commercial activities in order to obtain an official broadcasting license. Swaragama, an abbreviation for Swara Gadjah Mada ('The Voice of Gadjah Mada'), is the student's radio of the Gadjah Mada University in Yogyakarta, one of the oldest and most prestigious universities in Indonesia. Swaragama began its production and broadcasting activities in September 1999. Although it received official commercial status in February 2000, it has continued to present itself as a 'public' alternative to both government and profit-oriented radio. In order to attract an audience of educated youth, the radio station fosters an image of rebellion, solidarity and alternative organization, which is presented as the very traits of community radio.

It appears that two past radio categories in Indonesia, that is government radio and commercial broadcast radio, are still insufficient in fulfilling all the hopes and idealism of the public. This has been proven by the academic civil community movement and 'guerrilla' struggling for the presence of a third form of radio. The fact that radio clubs are often confronted with ups and downs because of limited resources, or because of the thickness of the bureaucratic wall, has actually enhanced their militancy in organizing their movement. Some people define this alternative category as social radio, campus radio, community radio, et cetera. Radio Swara Gadjah Mada is back again with its identity as 'campus-based radio', making use of the current corridor for developing a vision about radio that is based on the idealistic principles of education and democratization. (Swara Gadjah Mada 2001.)

Swaragama's anti-establishment messages - reflected in the use of words such as pergerakan ('movement'), guerrilla and militansi ('militancy') - seem to support a carefully constructed commercial image and to represent nostalgia for student activism rather than real struggle or ideals. Nevertheless, the quote also shows Swaragama's awareness of the character and possibilities of the medium of radio - including its potential for Brechtian refunctioning, as I will explain later - and the role and position of community radio in the 
contemporary Indonesian media scene as well as Indonesian society at large. Community radio's guerrilla, as envisioned by Swaragama, also embodies a new type of patriotism, which is realized on a local grass-roots level, inspired by international examples, and partly meant to serve the national cause.

The Swara Gadjah Mada brochure (2001) mentions the following four traits of campus radio: 1 . It is based on campus, 2 . It is managed by students and staff, 3. Its target audience is students and staff, and 4. Its programmes and broadcasting style represent the ideas and activities of the campus community. The informational and educational programmes provided by campus radio are supposed to constitute an alternative to the entertainment of commercial radio and the government messages of state radio. According to the brochure, Indonesian campus radio constitutes a new form of public radio, which contributes to and is a product of social developments such as Reformasi, regional autonomy and the improvement of the Indonesian education system.

Swaragama's crew consists of current and former students of the Gadjah Mada University and some other Yogyakarta universities. The radio station received funding for equipment from Gadjah Mada University, while it covers its operational costs by selling air time to advertisers. Swaragama also organizes off-air activities, such as music concerts and basketball games.

The station has daily broadcasts from 11 a.m. to 8 p.m. Its programmes focus on topics such as education, music, politics, religion and student life. Examples are 'Kampus kita' ('Our campus', about the life at Yogyakarta universities), 'Parwi' (an abbreviation for Parliament watch Indonesia, about local politics in Yogyakarta and Central Java), 'Mutiara iman' ('The pearls of faith', about Islam), 'Warung agape' ('Food stall for God's love', about Christianity), 'Indo prima' ('Indonesia first-class', containing entertainment), 'Jogyakarya' ('Yogya works', promoting music bands from Yogyakarta), 'Bahana persada' ('The sound of the homeland', about Indonesian music), 'Evening drive' (containing Western music), 'Hits of yesterday' (containing so-called 'oldies'), 'Alternasound' (containing alternative music) and 'Smaradahana' ('The fire of [the God of] love', 6 containing Western and Indonesian love songs).

Both on and off air, Swaragama pays much attention to pop music. This puts Swaragama's anti-establishment messages into a different perspective and confirms that the station is very similar to regular commercial radio in terms of organizational structure and programme content. Two examples of Yogyakarta campus stations that have not applied for commercial status are Saraswati and Masdha. Although their non-commercial status has caused

6 This is the name of an Old Javanese kakawin (poem) and also another name for the Javanese metre Asmarandana. 
them serious financial and organizational problems, it has also provided them with a more genuine community character.

Saraswati is the campus station of Yogyakarta's arts academy Institut Seni Indonesia (ISI, Indonesian Institute of Arts). It was founded in 1998 and named after ISI's patroness Saraswati, Hindu goddess of wisdom and literacy. The station has daily broadcasts from 4 to 12 p.m., including drama, music (jazz, rock, classical music), discussions on music and ethnomusicology, art courses, discussions of art works by ISI students, an art events calendar, tips for students living at boarding-houses, information about different Indonesian ethnic groups, and religion. ${ }^{7}$

The Saraswati crew and listeners consist of ISI students and people living in the campus neighbourhood. The listeners and the ISI directorate provide the station with funding. The students who work at Saraswati follow broadcasting courses at the communications departments of Yogyakarta universities and also receive in-house training from the AJI Yogyakarta branch. Other inspiration sources for programme production are community radio in the Philippines and the Internet radio of the University of California, Los Angeles. ${ }^{8}$

One of Saraswati's ideals is to develop art and stimulate creativity and critical thinking. According to Dani, one of the crew members, commercial radio turns people into consumers, hedonists and passive followers, while government or public radio only provides superficial news and information. ${ }^{9}$ He believes there is a need for information on art and culture in Indonesia, as these fields were obliterated during the New Order. In Middleton's terms, Saraswati aims to develop programmes with a high 'critical' mode, and to contribute to alternative media structures and information flows in Indonesia.

Masdha is the campus station of the catholic Sanata Dharma University. It had broadcasts for three years during the early 1990s, but was forced to stop its activities due to license requirements and government criticism on some of its programme content. In 1998, immediately after the fall of Suharto, the station was on air again.

Masdha receives funding from the Sanata Dharma directorate and training, broadcasting facilities and programme material from national and international NGOs and media organizations. The crew follows training courses organized by KBR 68H, Internews Indonesia, BBC Indonesia, AJI Yogyakarta, RRI Yogyakarta and Unisi, amongst others. For Masdha as well as other campus stations, it is difficult to maintain continuity in production and broadcasting, as their crews normally change with every new generation of students. ${ }^{10}$

7 Dani, personal communication, Yogyakarta, 29-8-2001.

8 Dani, personal communication, Yogyakarta, 29-8-2001.

9 Dani, personal communication, Yogyakarta, 29-8-2001.

10 Yuga, personal communication, Yogyakarta, 3-9-2001. 
Masdha has daily broadcasts from 5 until 2 a.m. (21 hours). Its programmes contain music, news, education and religion. News and education programmes are relayed from Internews Indonesia, KBR $68 \mathrm{H}$ and Radio Nederland, and religious programmes from Christian radio stations such as Santec (Germany), Veritas (Philippines) and Radio Vatican (Vatican City). Masdha attempts to treat young people as 'active subjects' rather than 'passive objects' by making information accessible to them and encouraging their participation in media communications and other social activities. The station deliberately presents its programmes in a non-formal language that can be easily understood by youth, and also regularly organizes broadcasting courses for high-school students. ${ }^{11}$

\section{Grassroots theatre, Brecht; Umfunktionierung and Verfremdung}

Contemporary Indonesian community stations such as Angkringan, Suara Petani Klaten, Saraswati and Masdha can be seen as the legal successors of the small-scale radio liar (literally: 'wild radio') or unlicensed private radio stations of the early New Order period (Sen 2003:582; Lindsay 1997:111-2). Radio liar included stations run by the 1966 student movement 'that challenged the official news on RRI and also broadcast Western popular music that had been discouraged nationally and banned from RRI broadcasts during the Old Order' (Lindsay 1997:112). There are also continuities and similarities between the community radio since the late 1990s and the so-called 'grassroots' theatre of the 1970s and 1980s. The theatre and radio initiatives have involved many of the same actors, and both been partly modelled on the People Powermovement in the Philippines and Bertolt Brecht's ideas on theatre and radio.

While initially using Brecht's ideas intuitively as a framework for understanding Indonesian community radio (Jurriëns 2003), it was after reading Michael Bodden's (1993) work on grassroots theatre in Indonesia and the Philippines that I realized that there are solid links between radio and theatre, and between Brecht and Indonesia. One of the Indonesian theatre groups discussed by Bodden is Arena, which was founded in 1964 and became affiliated to the Centre for the Production of Educational Catechism Media, Yogyakarta, in 1971. Through workshops, books and personal correspondence, Arena was directly influenced by Philippine grassroots theatre, the revolutionary Brazilian educator Paolo Freire, the Canadian cultural activist Ross Kidd and the Brazilian theatre activist and playwright Augusto Boal. Boal's own ideas were partly based on and complementary to Brecht's vision 
on theatre and society (Bodden 1993:279-80, 308-9). Inspired by these different sources, Arena developed its own version of grassroots theatre during the 1980s.

Arena's first artistic leader was Fred Wibowo, who would later become the managing director of the audio-visual studio of Pusat Pengembangan Masyarakat (PUSKAT, Centre for Societal Development), the successor of the Centre for the Production of Educational Catechism Media. In Wibowo's view, grassroots theatre had to be a pesta rakyat ('people's festival') along the following, partly Brechtian, principles: 1 . The story has its roots in local social conditions, 2 . The script is created and arranged by the community members, 3 . The performance has a straightforward structure, 4 . There are no barriers between performers and audience, 5 . The play is not aimed at catharsis, and 6. The play is aimed at creating dialogue between people who live under similar social conditions (Bodden 1993:317-9).

The community radio adage 'for, about and by the people' demonstrates many of these principles. Wibowo, in his capacity as director of PUSKAT, was directly involved in the development of community radio and other community-based media projects. ${ }^{12}$ PUSKAT's current priority - reflecting its own religious, catholic foundations - is to ease some of the religious tension in Indonesia and elsewhere in the world, and stimulate inter-religious understanding and dialogue through various media and activities.

At its impressive domain in the Sinduharjo village, north of Yogyakarta, PUSKAT has a fully equipped radio and television training studio, halls for seminars, conferences and religious services, and a camping site including ten cottages, a bungalow and a swimming pool (PUSKAT 2001b). The radio and television facilities are used for courses on television journalism, television scriptwriting, television and video production, sinetron (Indonesian soap opera) production, public radio management, and 'alternative' media, such as people's theatre, photography, cartoons and posters (PUSKAT 2001c). PUSKAT organizes special summer courses for children about television, photography and theatre (PUSKAT 2001a). It also offers facilities for alternative tourism around the themes of culture, religion and agriculture (PUSKAT 2001d). PUSKAT's own community radio station is called Balai Budaya Minomartani, which specifically focuses on children programmes and Javanese arts including wayang kulit and gamelan. 13

The ideas and practices of PUSKAT and the Central Javanese community stations discussed are close to the ideal of the Umfunktionierung or 'refunctioning' of art and media communications as developed by Brecht and reworked

12 Wibowo, personal communication, Yogyakarta, 31-8-2001.

13 Surowo Haryono, personal communication, Yogyakarta, 2-8-2002; see also Bodden 1993:314. 
by Benjamin in the Europe of the 1930s.

An artist's contribution now, he [Benjamin] says, must be assessed by reference to his positioning within the process of production. Using the methods offered by the new technical media, he must become a self-aware participant in the total apparatus of production. He must work towards an Umfunktionierung, as Brecht called it - a transformation of the apparatus - which will result in new fusions and relationships between media, genres and techniques, new, more collective production processes, and a new, more participative role for audiences. Content - however radical - can always be appropriated by the existing cultural powers; for Benjamin, then, cultural politics must become more of a running guerilla war, in which any appropriate materials, tactics, techniques and relationships may be used. (Middleton 1990:66.)

Perhaps coincidentally, but probably not, some of the Indonesian community stations today have also defined themselves as 'guerilla radio'. These stations are able to contribute to a refunctioning of the process of mediation partly because of the invention of new technologies - including the Internet - and forms of media interconnectivity - between radio and the telephone, for instance - partly because of changed visions on the interrelations between culture, politics and society. It is not surprising that Brecht himself called his vision 'utopian', as both he and Benjamin wrote against the background of the growth of Stalinism and fascism, which used the mass media as tools to disseminate propaganda and control the masses. The development of community radio would have pleasantly surprised Brecht, as it meets his ideals of listeners having influence in radio ownership, management and programme production, and radio functioning as a truly interactive medium for creating ideological awareness through multi-faceted dialogue.

Radio is one-sided when it should be two- [sided]. It is purely an apparatus for distribution, for mere sharing out. So here is a positive suggestion: Change this apparatus over from distribution to communication. The radio would be the finest possible communication apparatus in public life, a vast network of pipes. That is to say, it would be if it knew how to receive as well as to transmit, how to let the listener speak as well as hear, how to bring him into a relationship instead of isolating him. On this principle the radio should step out of the supply business and organize its listeners as suppliers. Any attempt by the radio to give a truly public character to public occasions is a step in the right direction. (Brecht 1993:15.)

The refunctioning of radio also implies another Brechtian concept that suits the analysis of Central Javanese community radio: Verfremdung or 'alienation'. Verfremdung is a Brechtian theatre concept that includes a critique of Aristotelian drama traditions. In Aristotelian drama, the audience is stimulated to identify with the characters represented by the actors. Through this process of identification with the story and its characters (in Brechtian terms: 
Einfühlung), the audience can attain catharsis, or a ritual purification of their feelings of fear and compassion (Brecht 1978a:161). According to Brecht (1978b:163-4), however, such identification leads to passivity and compliance, as it draws the audience from the real world into the dream world of the arts. Therefore he proposes the technique of alienation, which disrupts the coherence and natural flow of a play, and stimulates the audience to historicize and evaluate the social legitimacy of the event represented as well as their community life (Brecht 1978c:167).

A similar type of Verfremdung applies to Central Javanese community radio. By entering the medium simultaneously or consecutively as listeners, producers or managers, the radio audience has the opportunity and power to present itself and its stories in an alienating context, different from face-toface interaction. This new context, which possibly also stimulates the home audience to provide other reactions than in normal 'unmediated' discourse, consists of the flow of public, commercial and community media that introduces and connects the community to new paradigms for the representation of people, time and place. Through this process of alienation or recontextualization, the origins, structure and impact of shared stories that otherwise, in an unmediated context, would have been taken for granted as uncomplicated parts of an integrated social narrative, are placed in a new light that opens alternative perspectives for imagining one's community.

\section{Nostalgia for aura}

One may still wonder why a small community - such as the inhabitants of Timbulharjo or the ISI students - would need the electronic media for communication and the creation of a feeling of togetherness, when its members can and do easily interact with each other in unmediated ways. In other words, what is the attraction for people to witness themselves being represented in a medium such as community radio? Returning to Benjamin's argument about aura, I believe community radio is attractive because it satisfies a longing for intimacy and immediacy, and, paradoxically, also represents nostalgia for aura.

Intimacy and immediacy are not unique to community media, but also part of the mass media's capacity to enhance the accessibility of an event. Modern camera, editing and montage techniques, including close-ups, even show details and present a totality of an event that could never be noticed by a 'live' witness (Benjamin 1977:34; Dayan and Katz 1992:95). Philip Auslander (1992:32) points out the irony that video screens and other media tools and techniques are often used during live performances in order to bring back the immediacy and intimacy from which 'liveness' used to derive its attractive- 
ness and authority. Similarly, community radio can illuminate aspects of the lives of listeners that otherwise would have gone unnoticed, and renew the listeners' contact with their own community.

Although community radio with its immediacy and intimacy shatters the aura of the live event, the same medium also introduces 'nostalgic' feelings for auratic uniqueness and authenticity. This nostalgia for aura should be distinguished from the auratic or ceremonial qualities of media events. While community radio shows nostalgia for the 'here and now' of a live performance or local social conditions, media events produce a different type of aura underlining the 'here and now' of a media performance.

The ceremoniality of media events resides in the 'rare realization of the full potential of electronic media technology' (Dayan and Katz 1992:15) and the use of advanced recording, editing and broadcasting techniques. Community radio is 'nostalgic for aura' rather than 'auratic', as it neither recreates the aura of the live performance nor produces the ceremoniality of media events. Its nostalgia or longing for authenticity and uniqueness is ideologically rooted in the use of cheap and uncomplicated media technology. By presenting itself as a very basic medium, community radio attempts to distinguish itself from its competitors in the field, that is, public and commercial media. This relation between community radio on the one hand and public and commercial media on the other is comparable to the relation between rock and pop music.

The ideological distinction between rock and pop is precisely the distinction between the authentic and the inauthentic, the sincere and the cynical, the genuinely popular and the slickly commercial, the potentially resistant and the necessarily co-opted, art and entertainment (Auslander 1999:69).

Community radio's nostalgia mirrors rock music's claims to uniqueness and authenticity, as they are both ideological constructs that require legitimization by a live event (Auslander 1999:69, 83). Auslander (1999:84) argues that this quest for legitimacy is not unproblematic.

[In] rock's ideology of authenticity, a mass-produced recording must be authen-
ticated through the presence of a unique object, a live performance. To leave the
question at that would be to forget, however, that in rock, the live performance
is a recreation of the recording, which is, in fact, the original performance. Rock
ideology is in perfect accord with Benjamin in stipulating that because the original
artifact is mass-produced, its presence does not imply its authenticity. But it does
not follow for rock ideology as it does for Benjamin that this recognition entails
relinquishing the idea of authenticity. (Auslander 1999:84.)

When authenticity has gone, what is left is nostalgia for aura. Similar to the devotees of rock, the listeners of community radio ask for a form of legitimization, and expect the community radio content to meet the realities of social 
life. However, since life is just as mediatized as a regular rock concert, there are no theoretical grounds to consider community radio to be more authentic or unique than public or commercial media. The previous chapters showed that late- and post-Suharto commercial radio has been a refreshing alternative to New Order propaganda, while RRI has expressed the intention to reform itself from a government medium into a medium serving the public interest. Similar to community radio, both commercial and public radio often produce programmes with an interactive character and sometimes pay attention to small and marginalized groups in society. This makes the distinction between public, commercial and community radio far less rigid than my earlier summary of the UNESCO paradigm may have suggested.

Still, there are reasons to believe that community radio is more suitable than the other two types of radio for representing and analysing the interaction between real life and the media. Community radio confirms this not only by offering programmes and off-air activities about the media and other social issues, but also by enabling listeners to participate in different stages of the mediation process. The medium has a democratic right to exist in Indonesia, as it enables smaller groups in society to express themselves, and it also contributes to the diversity of the local media scene in terms of production, management and ownership. If people are free to communicate using any medium they want, why would community radio have to be excluded from other media such as unmediated conversation, print publications, the telephone and the Internet? Moreover, why would radio communication be the prerogative of government and business only?

Opponents of community radio have argued that the medium may be abused for promoting chauvinistic ideals or inciting violence against others. This argument is often made by people attempting to protect their commercial or political interests in private and public radio. While the danger of media abuse is always lurking - as Brecht, Benjamin, Habermas and others rightfully argue - this danger is not restricted to community radio, but also concerns commercial and public media. If there were community stations representing ideals that are indeed too narrow or aggressive to be accepted by other groups in society, this could still not be a reason to prohibit the medium as such. Rather, it should be an incentive for practitioners, politicians and legislators to take into serious consideration the recommendations made by groups such as Depok School, Indonesia Media Law and Policy Centre and Komunitas Televisi Publik Indonesia, which all pleaded for the media to be supervised by truly independent bodies. 


\section{Chapter ix \\ Conclusion \\ Reformasi and the dialogical public sphere}

Since the fall of President Suharto, Indonesian radio has developed and become a space for the discussion of matters of public relevance. It continues the journalistic ideas and practices that provided alternatives to the monologism of official New Order culture, including pasemon and plesetan. While these earlier alternatives were shaped in a climate of continuous heteroglossic frictions between the government and civil society, the socio-political and legal changes since the start of Reformasi relieved tensions and broadened the space for people to express themselves and represent their interests in public. Indonesian radio has been an efficient medium for disseminating the thoughts and feelings of the public as a result of several of its techno-cultural features, such as the oral and aural character of radio broadcasts and the relatively low costs of programme production, transmission and reception. At the same time, new threats to and limitations on the freedom of expression have emerged from within Indonesian civil society itself, including phenomena such as envelope journalism and violent attacks on journalists and media institutions by groups of civilians.

During Reformasi, different strategies have been developed for making the media represent the public interest. Media scholars, activists and practitioners pleaded for independent bodies supervising the media, which resulted in the establishment of institutions such as Radio Republik Indonesia's (RRI) dewan pengawas and the national broadcasting commission Komisi Penyiaran Indonesia (KPI). Concepts such as independent journalism, peace journalism, meta-journalism, virtual interactivity, talk-back radio and community radio were appropriated and further developed in response to New Order's monologism as well as specific social problems of the Reformasi period. Independent journalism can be seen as a reaction against New Order's government-controlled development journalism and a means to support journalism's Fourth Branch function as watchdog of the legislative, judicial and executive powers in society. Peace journalism arose in different forms against 
the background of the ethnic and religious conflicts in the Moluccas and elsewhere since the late 1990s, and aims at preventing escalations of violence by consoling audiences or giving them the opportunity to talk and think about the details of a conflict. Meta-journalism's main focus is to enhance the media literacy of journalists and audiences in order to make them less vulnerable to forms of media abuse. Virtual interactivity is meant to engage audiences in news events by providing them with ambient sounds and on-the-spot interviews. Talk-back radio stimulates direct audience participation in on-air discourse, while community radio enables listeners to become involved in media production, management and ownership.

Different media institutions have created a variety of public spheres due to their use of diverse journalistic concepts or institutional organization forms. Organizations such as Kantor Berita Radio 68H (KBR 68H), Internews Indonesia and Indonesia Media Law and Policy Centre (IMLPC) can be considered the creators and representatives of a Habermasian bourgeois public sphere that facilitates institutionalized forums for rational debate on matters of public interest. Trijaya's talk show 'Jakarta first channel' constitutes a similar forum, in which experts and occasionally also listeners engage in critical debate on behalf of the public and in accordance with the rules of multi-sided journalism. Some current affair programmes, including Suara Surabaya's 'Kelana kota' and Jakarta News FM's 'Features sang guru', attempt to create practical solutions to public matters ranging from traffic jams, criminality and city infrastructure, to health care, education and the environment. The majority of the interactive news programmes on Indonesian radio are instances of the oppositional public sphere, in which the outcome of debate is less a priority than the creation of opportunities for listeners to participate in and learn from the dynamics of debate.

The meta-journalistic initiatives that can be found in Indonesian radio give shape to a third type of public sphere, which is characterized by Bakhtinian dialogism. This dialogical public sphere does not exclude the other two public spheres, but often shares similar values and practices. I see the Indonesian dialogical public sphere as a product of the awareness of journalists and audiences that press freedom is only sustainable when media literacy is spread, or knowledge about how the media work and which ideological or commercial interests they represent. The greatest crime of New Order monologism was not only that it did not allow people to talk for themselves, but also that it attempted to suppress any initiative by the public to examine the premises on which the official discourse was based. In contemporary Indonesia, dialogical or meta-journalistic investigations into the role of the media have become an integral part of radio programmes such as IMLPC's 'Mengawal kekebasan pers', Suara Surabaya's 'Lembaga konsumen media' and Trijaya's 'Jakarta first channel'. Off-air activities have also functioned as dialogical forums for 
the discussion of media-related issues, such as Friedrich Naumann Stiftung's competitions for radio stations and Global FM's 'Jumpa pendengar' event and 'Tokoh pemberdayaan masyarakat' contest for radio listeners. The opportunities for the public to monitor broadcast content and organizational forms have grown with the establishment of institutions such as community radio, KPI and RRI's dewan pengawas.

The programmes 'Mengawal kebebasan pers', 'Lembaga konsumen media' and 'Jakarta first channel' exemplify how different genres or programmes establish different relations between the dialogical public sphere on the one hand and the bourgeois and oppositional public spheres on the other. 'Mengawal kebebasan pers' has the format of a feature in which a host discusses relevant media legislation and case-studies about media abuse; 'Lembaga konsumen media' is a talk show in which a host, invited media experts and listeners talk about the role of the media and their impact on daily life; and 'Jakarta first channel' has the format of a rational debate in which hosts, interviewees and sometimes also listeners discuss socio-political topics including the media in an orderly manner. These different formats have consequences for the way in which the public and their interests are represented.

In 'Mengawal kebebasan pers' a specialist discourse is used on behalf of the public; in 'Lembaga konsumen media' listeners have the opportunity to talk about their own ideas and experiences in a direct manner; and in 'Jakarta first channel' representatives of different interest groups interact with each other in accordance with the concept of multi-sided journalism. In general, 'Mengawal kebebasan pers' and 'Jakarta first channel' are closer to representing the ideals of Habermas' bourgeois public sphere, as they use rational debate to reach consensus on a particular topic, while 'Lembaga konsumen media' is closer to the ideals of the oppositional public sphere, as it focuses on the process rather than the outcome of discursive interaction. While this implies that not all programmes involve their audiences in literal dialogue to the same extent, the programmes all belong and contribute to what could be called a dialogical public sphere in Bakhtinian sense, as they represent the attempts of Indonesian programme producers to develop (radio) journalism and safeguard the value of press freedom by making journalists and audiences media-literate.

In other words, contemporary Indonesian radio journalism not only contradicts Habermas' assumption that the mass media are unsuitable for defending the public cause, but also confirms the existence of alternatives to the bourgeois public sphere. At the same time, Habermasian concepts such as the 'refeudalization of society' are far from irrelevant to the contemporary Indonesian media landscape. The case of Mora demonstrates that companies sometimes use 'publicness' as a marketing strategy to serve and hide their 
own commercial interests in the media. Many talk shows for requesting songs and sending greetings to family and friends are mere manifestations of the 'externalization of inner life' and do not serve the interests of the larger community. Non-profit organizations are often partly subjected to the agenda of international governments or NGOs, and community radio is not free from the risk of being hijacked by the chauvinistic ideals of a single group.

However, it is precisely these ways of compromising the public interest that are revealed and countered by Indonesian meta-journalistic radio journalism. Apart from the earlier mentioned examples, independent organizations such as KBR $68 \mathrm{H}$ and Internews Indonesia have emerged, which not only produce news and information but also programmes and workshops about journalism and the media in order to enhance the media literacy of the Indonesian public. There are also commercial stations such as Global FM and community stations such as Angkringan, which broadcast talk shows in which listeners can participate in discussions on topical issues as well as criticize or alter the format of the programmes themselves. Through its slogans and competition for 'Social empowerment personalities', Global FM asks listeners not only to monitor the actions of politicians and corporate businessmen - in itself a great achievement of late and post-New Order radio - but also to hold the radio station's crew and audience accountable for their on-air behaviour. These types of initiatives are concrete illustrations of the spirit of Reformasi, especially its ideals of media transparency and accountability.

Finally, the various radio-active public spheres discussed in this book and their concomitant articulations of Reformasi are by no means intrinsically Indonesian phenomena. The international marketing strategy of media segmentation links local audiences to audiences elsewhere, categorized as similar segments, but situated in different socio-political contexts. The contemporary Indonesian media scene also offers listeners the opportunity to become 'virtual travelers' (Jurriëns 2004) and get a sense of other worlds beyond their own by listening to foreign news and information that is relayed by local commercial radio. Their virtual travel may also be facilitated by a local radio news agency or community station collaborating with a national or international NGO, or by scholars bringing foreign ideas on media, journalism and the public sphere to Indonesia. Listeners are able to share their real or virtual travel experiences with others by giving comments on regional, national and international affairs in local talk-back radio. These examples confirm that the various public spheres steered by Indonesian radio communications are in many cases simultaneously informed by, and transcend the distinctions between, the regional, the national and the international (see Jurriëns and De Kloet 2007).

Bruce Robbins (1998:7) has argued that if modern mass communications are not restricted to specific geographical or administrative borders, it would 
be inconsistent to assume that the process of imagining a sense of community would not go beyond the limitations of such borders either.

If people can get as emotional as [Benedict] Anderson says they do about relations with fellow nationals they never see face-to-face, then now that print-capitalism has become electronic- and digital-capitalism, and now that this system is so clearly transnational, it would be strange if people did not get emotional in much the same way, if not necessarily to the same degree, about others who are not fellow nationals, people bound to them by some transnational sort of fellowship (Robbins 1998:7).

Radio journalism of the late- and post-Suharto periods has indeed enabled parts of the Indonesian population to undergo experiences and build identities that go beyond their local societies, and perhaps has made them feel like members of a cosmopolitan community. Basing himself on Paul Rabinow, Robbins (1998:1) explains that cosmopolitanism used to be applied, 'often venomously', to certain groups - including Christians, aristocrats, merchants, Jews, homosexuals and intellectuals - with the financial or educational capital to travel to, or receive guests, goods or information from, distant places. 'Now it [cosmopolitanism] is attributed, more charitably, to North Atlantic merchant sailors, Caribbean au pairs in the United States, Egyptian guest workers in Iraq, Japanese women who take gaijin [non-Japanese] lovers'. I believe to this list could be added the people involved in contemporary Indonesian radio journalism, including the KBR $68 \mathrm{H}$ news bulletin producers in Jakarta, the participants in the current affairs talk shows of Global FM in Tabanan, or the manager-listeners of Angkringan in Timbulharjo, who all make us realize that their concern is also our concern. 



\section{List of abbreviations and acronyms}

$\begin{array}{ll}\text { AFP } & \text { Agence France-Presse, Press Agency of France } \\ \text { AJI } & \text { Aliansi Jurnalis Independen, Alliance of Independent Journalists } \\ \text { AMARC } & \text { Association Mondiale des Radiodiffuseurs Communautaires, } \\ & \text { World Association of Community Radio Broadcasters } \\ \text { APEC } & \text { Asia-Pacific Economic Cooperation } \\ \text { BRV } & \text { Bataviaasche Radio Vereeniging, Batavian Radio Society } \\ \text { BUMN } & \text { badan usaha milik negara, state-owned corporation } \\ \text { CRI } & \text { Combine Resource Institution } \\ \text { DPR } & \text { Dewan Perwakilan Rakyat; Indonesian Legislative Assembly, } \\ & \text { Parliament } \\ \text { FDP } & \text { Free Democratic Party } \\ \text { FNS } & \text { Friedrich Naumann Stiftung } \\ \text { FORAKI } & \text { Forum Radio Kampus Indonesia, Indonesian Campus Radio } \\ & \text { Forum } \\ \text { FPI } & \text { Front Pembela Islam, Cadre of Defenders of Islam } \\ \text { HPPI } & \text { Himpunan Praktisi Penyiaran Indonesia, Association of } \\ \text { IMLPC } & \text { Indonesian Broadcasting Practitioners } \\ \text { ISAI } & \text { Indonesia Media Law and Policy Centre } \\ & \text { Institut Studi Arus Informasi, Institute for the Studies on Free } \\ \text { ISI } & \text { Flow of Information } \\ \text { KBR 68H } & \text { Institut Seni Indonesia, Indonesian Institute of Arts } \\ \text { Kelompencapir } & \text { Kantor Berita Radio 68H, Radio News Agency 68H } \\ \text { KEWI } & \text { Kelompok Pendengar, Pembaca dan Pemirsa; Listener, Reader and } \\ \text { KKB } & \text { Kode Etik Wartawan Indonesia, Indonesian Journalists Code of } \\ \text { KKN } & \text { Ethics } \\ \text { KPI } & \text { Koperasi Krama Bali, Balinese Citizen's Cooperatives } \\ \text { KPKPN } & \text { korupsi, kolusi dan nepotisme; corruption, collusion and nepotism } \\ \text { KTVPI } & \text { Komisi Penyiaran Indonesia, Indonesian Broadcasting } \\ \text { LKM } & \text { Commission } \\ \text { LKP } & \text { Komisi Penyelidik Kekayaan Pejabat Negara, Commission of } \\ & \text { Investigators of State Officials' Wealth } \\ \text { Komunitas Televisi Publik Indonesia, Community for Indonesian } \\ \text { Public Television } \\ \text { Lembaga Konsumen Media, Institute of Media Consumers } \\ & \end{array}$




\begin{tabular}{|c|c|}
\hline LPS & Lembaga Produksi Siaran, Broadcast Production Institute \\
\hline LP3Y & Lembaga Penelitian, Pendidikan dan Penerbitan Yogyakarta; \\
\hline LSPP & $\begin{array}{l}\text { Lembaga Studi Pers dan Pembangunan, Institute for Press and } \\
\text { Development Studies }\end{array}$ \\
\hline MPR & Majelis Permusyawaratan Rakyat, People's Consultative Council \\
\hline NGO & Non-governmental organization \\
\hline NWICO & New World Information and Communication Order \\
\hline PD & Partai Demokrat, Democratic Party \\
\hline PDI-P & $\begin{array}{l}\text { Partai Demokrasi Indonesia-Perjuangan, Indonesian Democracy } \\
\text { Struggle Party }\end{array}$ \\
\hline PFA & Press Foundation of Asia \\
\hline OLRI & Polisi Republik Indonesia, Police of the Republic of Indonesia \\
\hline PRSSNI & $\begin{array}{l}\text { Persatuan Radio Siaran Swasta Nasional Indonesia, Indonesian } \\
\text { National Association for Commercial Broadcast Radio }\end{array}$ \\
\hline PTPN & $\begin{array}{l}\text { Perseroan Terbatas Perkebunan Nusantara, The Archipelago } \\
\text { Plantation Incorporated }\end{array}$ \\
\hline PUSKAT & $\begin{array}{l}\text { Pusat Pengembangan Masyarakat, Centre for Societal } \\
\text { Development }\end{array}$ \\
\hline PWI & $\begin{array}{l}\text { Persatuan Wartawan Indonesia, Association of Indonesian } \\
\text { Journalists }\end{array}$ \\
\hline RCTI & $\begin{array}{l}\text { Rajawali Citra Televisi Indonesia, 'The Black Hawk of Indonesian } \\
\text { Television Image' }\end{array}$ \\
\hline RRI & Radio Republik Indonesia, Radio of the Republic of Indonesia \\
\hline SARA & $\begin{array}{l}\text { Suku, Agama, Ras, Antargolongan; Ethnicity, Religion, Race and } \\
\text { Inter-Group Relations }\end{array}$ \\
\hline SCFM & $\begin{array}{l}\text { Surabaya Cakra Awigra FM, 'Surabaya Wheel of Frequency } \\
\text { Modulation' }\end{array}$ \\
\hline SCTV & Surya Citra TV, 'The Sun of Television Image' \\
\hline SET & $\begin{array}{l}\text { Yayasan Sains, Estetika dan Teknologi; Science, Aesthetics and } \\
\text { Technology Foundation }\end{array}$ \\
\hline SIUPP & $\begin{array}{l}\text { Surat Izin Usaha Penerbitan Pers, Press Publishing Company } \\
\text { Permit }\end{array}$ \\
\hline TNI & Tentara Nasional Indonesia, Indonesian National Army \\
\hline TPI & Televisi Pendidikan Indonesia, Indonesian Education Television \\
\hline TUK & Teater Utan Kayu, Utan Kayu Theatre \\
\hline TVRI & $\begin{array}{l}\text { Televisi Republik Indonesia, Television of the Republic of } \\
\text { Indonesia }\end{array}$ \\
\hline UI & Universitas Indonesia, University of Indonesia \\
\hline UNESCO & United Nations Educational, Scientific and Cultural Organization \\
\hline USAID & United States Agency for International Development \\
\hline USIA & United States Information Agency \\
\hline VCD & Video Compact Disc \\
\hline
\end{tabular}




\section{Bibliography}

For convenience's sake, Indonesian personal names are listed according to the last part of their name

Ajidarma, Seno Gumira

1997 Ketika jurnalisme dibungkam sastra harus bicara. Yogyakarta: Yayasan Bentang Budaya.

Anderson, Benedict R.O'G.

1990 Language and power; Exploring cultures in Indonesia. Ithaca/London: Cornell University Press. [The Wilder House series in politics, history and culture.]

1991 Imagined communities; Reflections on the origin and spread of nationalism. Revised edition. London/New York: Verso. [First edition 1983.]

Ansah, Paul A.V.

1986

'The struggle for rights and values in communication', in: Michael Traber (ed.), The myth of the information revolution, pp. 64-83. London: SAGE Publications. [SAGE Communications in Society series.]

Arps, Bernard 2003

'Letters on air in Banyuwangi (and beyond); Radio and phatic performance', Indonesia and the Malay World 31:301-16.

Auslander, Philip

1999 Liveness; Performance in a mediatized culture. London/New York: Routledge.

Bakhtin, M.M.

1981

The dialogic imagination; Four essays by M.M. Bakhtin. Edited by Michael Holquist. Translated by Caryl Emerson and Michael Holquist. Austin: University of Texas Press. [University of Texas Press Slavic Series 1.]

1984a Problems of Dostoevsky's poetics. Edited and translated by Caryl Emerson. Minneapolis: University of Minnesota Press. [Theory and History of Literature 8.]

1984b Rabelais and his world. Translated by Hélène Iswolsky. Bloomington: Indiana University Press. [A Midland Book 341.]

Barker, Joshua

2003

'Interkom in Indonesia; Not quite an imagined community', in: James T. Siegel and Audrey R. Kahin (eds), Southeast Asia over three generations; Essays presented to Benedict R.O'G. Anderson, pp. 383-96. Ithaca, NY: Cornell University Press. [Studies on Southeast Asia 36.] 
Benjamin, Walter

1977 Das Kunstwerk im Zeitalter seiner technischen Reproduzierbarkeit; Drei Studien zur Kunstsoziologie. Tenth edition. Frankfurt am Main: Suhrkamp Verlag. [First edition 1955.]

Bodden, Michael H.

1993

Imagining the audience as agent of its own history; Brecht, grassroots theater and representations of interclass alliance in the Philippines and Indonesia. $\mathrm{PhD}$ thesis, University of Wisconsin, Maddison.

Brecht, Bertolt

1978a ['Kritik der "Poetik" des Aristoteles'], in: Heinz Geiger and Hermann Haarmann (eds), Aspekte des Dramas, pp. 161-2. Opladen: Westdeutscher Verlag. [First published 1967.]

1978b 'Über experimentelles Theater', in: Heinz Geiger and Hermann Haarmann (eds), Aspekte des Dramas, pp. 163-5. Opladen: Westdeutscher Verlag. [First published 1939.]

1978c '(Vierter) Nachtrag zur Theorie des "Messingkaufs", in: Heinz Geiger and Hermann Haarmann (eds), Aspekte des Dramas, pp. 166-8. Opladen: Westdeutscher Verlag. [First published 1940.]

1993

'The radio as an apparatus of communication', in: David Strauss and Dave Mandl (eds), Radiotext(e), pp. 15-7. New York: Semiotext(e). [Semiotext(e) 16; First published 1932.]

Browne, Donald R.

1978 'International broadcasting to Asia', in: John A. Lent (ed.), Broadcasting in Asia and the Pacific; A continental survey of radio and television, pp. 31838. Hong Kong: Heinemann Asia.

Calhoun, Craig

1992 'Introduction; "Habermas and the public sphere"', in: Craig Calhoun (ed.), Habermas and the public sphere, pp. 1-48. Cambridge, MA/London: MIT Press. [Studies in Contemporary German Social Thought.]

Cook, Timothy E.

1998 Governing with the news; The news media as a political institution. Chicago/ London: University of Chicago Press.

Creese, Helen

2004

'Reading the Bali Post; Women and representation in post-Suharto Bali', Intersections. http://wwwsshe.murdoch.edu.au/intersections/ issue10/creese.html (accessed 2-3-2006). Article moved to http://intersections.anu.edu.au/issue10/creese.html (accessed 23-7-2009).

Dayan, Daniel and Elihu Katz

1992 Media events; The live broadcasting of history. Cambridge, MA/London: Harvard University Press.

Derks, Will 2004

'A literary mycelium; Some prolegomena for a project on Indonesian literatures in Malay', in: Timothy P. Barnard (ed.), Contesting Malayness; Malay identity across boundaries, pp. 181-202. Singapore: Singapore University Press. 
Foulcher, Keith

1993 'Post-modernism or the question of history; Some trends in Indonesian fiction since 1965', in: Virginia Matheson Hooker (ed.), Culture and society in New Order Indonesia, pp. 27-47. Kuala Lumpur: Oxford University Press. [South-East Asian Social Science Monographs.]

Fraser, Colin and Sonia Restrepo Estrada

2001 Buku panduan radio komunitas. Jakarta: UNESCO Jakarta Office.

Gazali, Effendi

2002a 'Dari editor', in: Effendi Gazali (ed.), Penyiaran alternatif tapi mutlak; Sebuah acuan tentang penyiaran publik dan komunitas, pp. viii-xi. Jakarta: Jurusan Ilmu Komunikasi FISIP, Universitas Indonesia.

2002b 'Memahami perbedaan lembaga penyiaran publik dan komersial', in: Effendi Gazali (ed.), Penyiaran alternatif tapi mutlak; Sebuah acuan tentang penyiaran publik dan komunitas, pp. 33-51. Jakarta: Jurusan Ilmu Komunikasi FISIP, Universitas Indonesia.

2002c 'Beberapa potensi kerancuan lain', in: Effendi Gazali (ed.), Penyiaran alternatif tapi mutlak; Sebuah acuan tentang penyiaran publik dan komunitas, pp. 52-69. Jakarta: Jurusan Ilmu Komunikasi FISIP, Universitas Indonesia.

2002d 'Mencoba memetakan dunia penyiaran kita dengan adanya lembaga penyiaran publik dan komunitas', in: Effendi Gazali (ed.), Penyiaran alternatif tapi mutlak; Sebuah acuan tentang penyiaran publik dan komunitas, pp. 84-95. Jakarta: Jurusan Ilmu Komunikasi FISIP Universitas Indonesia.

2002e 'Antara lembaga penyiaran publik dan komunitas', in: Effendi Gazali (ed.), Penyiaran alternatif tapi mutlak; Sebuah acuan tentang penyiaran publik dan komunitas, pp. 70-83. Jakarta: Jurusan Ilmu Komunikasi FISIP, Universitas Indonesia.

Global FM

2001

'Global FM 99,15 Kinijani Bali news letter; Edisi khusus HUT ke-2, 30 Mei 2001'. Newsletter, Global FM, Tabanan.

2002 'Radio Global 99,15 FM Bali; Edisi khusus HUT ke-3, 30 Mei 2002'. Newsletter, Global FM, Tabanan.

Habermas, Jürgen

1989a The structural transformation of the public sphere; An inquiry into a category of bourgeois society. Translated by Thomas Burger. Cambridge, MA: MIT Press. [Originally published as Strukturwandel der Öffentlichkeit. Darmstadt: Luchterhand, 1962.]

1989b Jürgen Habermas on society and politics; A reader. Edited by Steven Seidman. Boston: Beacon Press. [Selections translated from the German.]

Hae, Nur Zain, Rusdi Marpaung and Hawe Setiawan

$2000 \quad$ Konflik multikultur; Panduan meliput bagi jurnalis. Jakarta: LSPP.

Hale, Julian

1975 Radio power; Propaganda and international broadcasting. Philadelphia: Temple University Press.

Hasibuan, Imran and Sitok Srengenge (eds)

1996

Bredel di udara; Rekaman radio $A B C, B B C, D W$ Nederland, VoA. Jakarta: ISAI. 
Hefner, Robert W.

2000 Civil islam; Muslims and democratization in Indonesia. Princeton/Oxford: Princeton University Press.

Heryanto, Ariel

1996 'Bahasa dan kuasa; Tatapan posmodernisme', in: Yudi Latif and Idi Subandy Ibrahim (eds), Bahasa dan kekuasaan; Politik wacana di panggung Orde Baru, pp. 94-103. Bandung: Mizan.

Hidayat, Dedy N.

2002 'Neo liberalisme dan market dictatorship dalam industri penyiaran; Argumen bagi lembaga penyiaran publik', in: Effendi Gazali (ed.), Penyiaran alternatif tapi mutlak: Sebuah acuan tentang penyiaran publik dan komunitas, pp. 4-18. Jakarta: Jurusan Ilmu Komunikasi FISIP, Universitas Indonesia.

Hikam, Muhammad A.S.

1996 Demokrasi dan civil society. Jakarta: LP3ES.

Hill, David T.

1995 The press in New Order Indonesia. Jakarta: Sinar Harapan. [Originally published under the same title. Nedlands: University of Western Australia Press, 1994.]

Hill, David T. and Krishna Sen

1997 'Wiring the warung to global gateways; The Internet in Indonesia', Indonesia 63:67-89.

2005 The Internet in Indonesia's new democracy. London/New York: Routledge.

Hjarvard, Stig

1998 'TV news exchange', in: Oliver Boyd-Barrett and Terhi Rantanen (eds), The globalization of news, pp. 202-26. London: SAGE Publications.

Hodge, Errol

1995 Radio wars; Truth, propaganda and the struggle for Radio Australia. Cambridge: Cambridge University Press.

Holquist, Michael

1984 'Prologue', in: M.M. Bakhtin, Rabelais and his world, pp. xiii-xxiii. Bloomington: Indiana University Press. [A Midland Book 341.]

Howell, Jude and Jenny Pearce

2001 Civil society and development; A critical exploration. Boulder/London: Lynne Rienner Publishers.

Hutcheon, Linda

1989 The politics of postmodernism. London/New York: Routledge.

Indrianto, Antonius M.

2001 'Sekali di udara, lebih banyak di lapangan!'. Paper, UNESCO seminar 'Radio komunitas; Untuk demokrasi dan kesatuan bangsa', Yogyakarta, 4 September.

Jonathans, Errol

2000 'Jurnalistik radio', in: Layla S. Mirza (ed.), Politik dan radio; Buku pegangan bagi jurnalis radio, pp. 33-106. [Jakarta]: Friedrich Naumann Stiftung. Socrates di radio; Esai-esai jagad keradion. Yogyakarta: GongPlus. 
Jurriëns, Edwin

2003 'Radio komunitas di Indonesia; "New Brechtian theatre" di era Reformasi?', Antropologi Indonesia 72:116-30.

2004 Cultural travel and migrancy; The artistic representation of globalization in the electronic media of West Java. Leiden: KITLV Press. [Verhandelingen 216.]

2006 'Radio awards and the dialogic contestation of Indonesian journalism', Indonesia and the Malay World 34:119-49.

2007 'Indonesian radio culture; Modes of address, fields of action', Review of Indonesian and Malaysian Affairs (RIMA) 41-1:33-71.

2008 'Television dreams; Simulation, for a new reality of Indonesia', in: Ariel Heryanto (ed.), Popular culture in Indonesia; Fluid identities in post-authoritarian politics, pp. 143-63. London/New York: Routledge. [Routledge Media, Culture and Social Change in Asia 15.]

Jurriëns, Edwin and Jeroen de Kloet (eds)

2007 Cosmopatriots; On distant belongings and close encounters. Amsterdam/ New York: Rodopi. [Thamyris Intersecting; Place, Sex, and Race 16.]

Kartika, Sandra and Ida Rosdalina

1999

Konvensi tentang penghapusan segala bentuk diskriminasi terhadap perempuan. Jakarta: LSPP.

Kitley, Philip

2000 Television, nation, and culture in Indonesia. Athens, $\mathrm{OH}$ : Ohio University Center for International Studies. [Research in International Studies, Southeast Asia Series 104.]

2002 'Televisi bangsa baru; Television, Reformasi and renewal in Indonesia', Media International Australia 104:92-106.

2003 'Civil society in charge? Television and the public sphere in Indonesia after Reformasi', in: Philip Kitley (ed.), Television, regulation and civil society in Asia, pp. 97-114. London: Routledge Curzon.

Kleden, Ignas

1996

'Pemberontakan terhadap "narasi besar"; Membaca teks Putu Wijaya dengan pendekatan tekstual', in: Yudi Latif and Idi Subandy Ibrahim (eds), Bahasa dan kekuasaan; Politik wacana di panggung Orde Baru, pp. 318-41. Bandung: Mizan.

Kurasawa, A.

1987

'Propaganda media on Java under the Japanese 1942-1945', Indonesia 44:95-128.

Latif, Yudi and Idi Subandy Ibrahim (eds)

1996 Bahasa dan kekuasaan; Politik wacana di panggung Orde Baru. Bandung: Mizan.

Lewis, Peter M. and Jerry Booth

1989 The invisible medium; Public, commercial and community radio. Basingstoke: Macmillan Education.

Lindsay, Jennifer

1997

'Making waves; Private radios and local identities in Indonesia', Indonesia 64:105-23. 
Livingstone, Sonia and Peter Lunt

1994 Talk on television; Audience participation and public debate. London/New York: Routledge.

Loven, Klarijn

2003 Si Doel and beyond; Discourse on Indonesian television in the 1990s. PhD thesis, Universiteit Leiden, Leiden. [Published as Watching Si Doel; Television, language, and cultural identity in contemporary Indonesia. Leiden: KITLV Press, 2008. Verhandelingen 242.]

Maier, H.M.J. 1993

'From heteroglossia to polyglossia; The creation of Malay and Dutch in the Indies', Indonesia 56:37-65.

2004 We are playing relatives; A survey of Malay writing. Leiden: KITLV Press. [Verhandelingen 215.]

Mardianto, Herry and Antonius Darmanto

$2001 \quad$ Tradisi sastra Jawa radio. Yogyakarta: Kalika.

Masduki

2001

2003 Radio siaran dan demokratisasi. Yogyakarta: Jendela.

$2004 \quad K e b e b a s a n$ pers dan kode etik jurnalistik. Yogyakarta: UII Press.

Matheson Hooker, Virginia

1993 (ed.) Culture and society in New Order Indonesia. Kuala Lumpur: Oxford University Press. [South-East Asian Social Science Monographs.]

1996

McDaniel, Drew O.

'Bahasa dan pergeseran kekuasaan di Indonesia; Sorotan terhadap pembakuan bahasa Orde Baru', in: Yudi Latif and Idi Subandy Ibrahim (eds), Bahasa dan kekuasaan; Politik wacana di panggung Orde Baru, pp. 56-76. Bandung: Mizan.

1994 Broadcasting in the Malay world; Radio, television, and video in Brunei, Indonesia, Malaysia, and Singapore. New Jersey: Ablex.

McGoldrick, Annabel and Jack Lynch

$2001 \quad$ Jurnalisme damai; Bagaimana melakukannya? Jakarta: LSPP.

McPhail, Thomas L.

1987 Electronic colonialism; The future of international broadcasting and communication. Newbury Park: SAGE Publications. [SAGE Library of Social Research 126.]

Middleton, Richard

$1990 \quad$ Studying popular music. Milton Keynes/Philidelphia: Open University Press.

Mohamad, Goenawan

1993

Mora

2001
'Kesusastraan, pasemon', in: Goenawan Mohamad (author), Kesusastraan dan kekuasaan, pp. 117-28. Jakarta: Firdaus

'Bio data Mora FM 88.65; PT Radio Mora parna kasa'. Brochure, Mora, Bandung. 
Morris, Pam (ed.)

1994 The Bakhtin reader; Selected writings of Bakhtin, Medvedev, Voloshinov. London: Edward Arnold.

Mrázek, Jan

1999

'Javanese wayang kulit in the times of comedy; Clown scenes, innovation, and the performance's being in the present world; Part one', Indonesia 68:38-128.

Mrázek, Rudolf

2002

Engineers of happy land; Technology and nationalism in a colony. Princeton: Princeton University Press.

Muis, H.A.

1997

'Radio menyongsong abad 21', Radio; Majalah khusus 23 tahun PRSSNI Tingkat Jawa Barat 1997, pp. 23-5.

Muted voices

1996

'Muted voices; Censorship and the broadcast media in Indonesia'. Report, Article 19, London.

Nasir, Akhmad

2001 'Radio sebagai alat penguatan komunitas'. Paper, UNESCO seminar 'Radio komunitas; Untuk demokrasi dan kesatuan bangsa', Yogyakarta, 4 September.

Nugroho, Garin

2002

'Pengantar; Televisi untuk publik', in: Garin Nugroho (ed.), TV publik; Menggagas media demokratis di Indonesia, pp. vii-viii. Jakarta: Yayasan Sains Estetika dan Teknologi.

Nurdiana, Titis and Andreas Berthoni

2002 'Trik Soetojo menyiasati berita jadi informasi', Kontan 21(25 February):21.

Pabottinggi, Mochtar

1996 'Bahasa, kramanisasi, dan kerakyatan', in: Yudi Latif and Idi Subandy Ibrahim (eds), Bahasa dan kekuasaan; Politik wacana di panggung Orde Baru, pp. 154-69. Bandung: Mizan.

Pandjaitan, Hinca I.P.

2002 'Aspek hukum lembaga penyiaran komunitas', in: Effendi Gazali (ed.), Penyiaran alternatif tapi mutlak; Sebuah acuan tentang penyiaran publik dan komunitas, pp. 144-52. Jakarta: Jurusan Ilmu Komunikasi FISIP, Universitas Indonesia.

Pandjaitan, Hinca I.P., C.C. Chan, L.S. Schramm and L.N. Tabing (eds)

$2000 \quad$ Radio; Pagar hidup otonomi daerah. Jakarta: Internews Indonesia Media Law Department.

Pease, Edward C. and Everette E. Dennis (eds)

1995 Radio; The forgotten medium. New Brunswick/London: Transaction Publishers.

Peraturan Pemerintah

2005a Peraturan Pemerintah Republik Indonesia Nomor 11 Tahun 2005 tentang Penyelenggaraan Penyiaran Lembaga Penyiaran Publik. Legislative document, Government of Indonesia, Jakarta. 
Peraturan Pemerintah Republik Indonesia Nomor 12 Tahun 2005 tentang Lembaga Penyiaran Publik Radio Republik Indonesia. Legislative document, Government of Indonesia, Jakarta.

2005c Peraturan Pemerintah Republik Indonesia Nomor 13 Tahun 2005 tentang Lembaga Penyiaran Publik Televisi Republik Indonesia. Legislative document, Government of Indonesia, Jakarta.

PUSKAT

2001a

$2001 b$

$2001 c$

2001d

Radio awards

2000a

$2000 b$

2001
'Paket liburan sekolah'. Brochure, PUSKAT, Yogyakarta.

'Puskat audio visual studio; Center for production training and cultural resort'. Brochure, PUSKAT, Yogyakarta.

'Training komunikasi 2001'. Brochure, PUSKAT, Yogyakarta.

'Wisata alternatif 2001'. Brochure, PUSKAT, Yogyakarta.

'Karya pemenang radio awards 2000 dengan tema: Wakil kita di DPR'. Audio-cassette with recordings of awarded programmes, Friedrich Naumann Stiftung, Jakarta.

'Radio awards 2000/Lomba program radio; Kategori reportase, mini feature dan wawancara'. Brochure, Friedrich Naumann Stiftung, Jakarta.

'Radio program awards 2001/Lomba program radio; Kategori mini feature, reportase, interview'. Brochure, Friedrich Naumann Stiftung, Jakarta.

Rahardja, Prathama and Henry Chambert-Loir

1990 Kamus bahasa prokem. Second edition. Jakarta: Pustaka Utama Grafiti. [First edition 1988.]

Robbins, Bruce

1998

'Introduction part 1; Actually existing cosmopolitanism', in: Pheng Cheah and Bruce Robbins (eds), Cosmopolitics; Thinking and feeling beyond the nation, pp. 1-20. Minneapolis/London: University of Minnesota Press.

Romano, Angela

$2003 \quad$ Politics and the press in Indonesia; Understanding an evolving political culture. London/New York: RoutledgeCurzon.

2005 'Asian journalism; News, development and the tides of liberalization and technology', in: Angela Romano and Michael Bromley (eds), Journalism and democracy in Asia, pp. 1-15. London/New York: Routledge.

Samuel, Jérôme

2002 'Radios Indonésiennes; Comment survivre à l'Ordre Nouveau?', Archipel 64:289-321.

Schulte Nordholt, Henk

2002 'Introduction', in: Henk Schulte Nordholt and Gusti Asnan (eds), Indonesia in transition; Work in progress, pp. 1-24. Yogyakarta: Pustaka Pelajar.

Schultz, Julianne

1998

Reviving the Fourth Estate; Democracy, accountability and the media. Cambridge: Cambridge University Press. [Reshaping Australian Institutions.] 
Schwarz, Adam

$2004 \quad$ A nation in waiting; Indonesia's search for stability. Singapore: Talisman. Seligman, Adam B.

1992 The idea of civil society. Princeton: Princeton University Press.

Sen, Krishna

2003 'Radio days; Media-politics in Indonesia', The Pacific Review 16:573-89.

Sen, Krishna and David T. Hill

2000 Media, culture and politics in Indonesia. Melbourne: Oxford University Press.

Siegel, James T.

1986 Solo in the New Order; Language and hierarchy in an Indonesian city. Princeton: Princeton University Press.

2001 'Suharto, witches', Indonesia 71:27-78.

Siregar, Ashadi

2002 'TV Publik; Sisi lain agenda Reformasi', in: Garin Nugroho (ed.), TV publik; Menggagas media demokratis di Indonesia, pp. 3-11. Jakarta: Yayasan Sains Estetika dan Teknologi.

Spyer, Patricia

2002 'Fire without smoke and other phantoms of Ambon's violence; Media effects, agency, and the work of imagination', Indonesia 74:21-36.

2005 'Media and violence in an age of transparency; Journalistic writing on war-torn Maluku', in: Birgit Meyer and Annelies Moors (eds), Religion, media, and the public sphere, pp. 152-65. Bloomington: Indiana University Press.

Spyer, Patricia, Ben Arps, Edwin Jurriëns, Katinka van Heeren and Wiwik Sushartami 2002 'Indonesian mediations; The re-imagining and re-imaging of community(s) in transition', in: Henk Schulte Nordholt and Irwan Abdullah (eds), Indonesia in search of transition, pp. 177-206. Yogyakarta: Pustaka Pelajar.

Stam, Robert

1989 Subversive pleasures; Bakhtin, cultural criticism and film. Baltimore/ London: John Hopkins University Press.

Steele, Janet

2005

Wars within; The story of 'Tempo', an independent magazine in Soeharto's Indonesia. Jakarta: Equinox Publishing; Singapore: Institute of Southeast Asian Studies.

Strassler, Karen

2004 'Reformasi through our eyes'; Children as witnesses of history in post-Soeharto Indonesia'. Paper, Conference 'Media and the making of history in post-Suharto Indonesia', Leiden University, Leiden, 9-10 December.

Suara Surabaya

2002

'Suara Surabaya FM 100.55; Kepercayaan warga Surabaya'. Brochure, Suara Surabaya, Surabaya. 
Sunjaya, Mohamad

1996 'Prakata; Dari hobi mendengar radio', in: Imran Hasibuan and Sitok Srengenge (eds), Bredel di udara; Rekaman radio $A B C, B B C, D W$ Nederland, VoA, pp. v-viii. Jakarta: ISAI.

Suryadi

2005

'Identity, media and the margins; Radio in Pekanbaru, Riau (Indonesia)', Journal of Southeast Asian Studies 36:131-51.

Suryakusuma, Julia I.

2004 Sex, power and nation; An anthology of writings, 1979-2003. Jakarta: Metafor Publishing.

Suryawan, I Nugrah

2005 'Dari "pariwisata budaya" ke "Ajeg Bali" (beberapa perspektif perubahan wacana politik kebudayaan dan seni di Bali pasca rezim Soeharto)'. Paper, workshop 'Arts, culture and political and social change since Suharto', University of Tasmania, Launceston, 16-18 December.

Swara Gadjah Mada

2001 'PT. Radio Swara Gadjah Mada 98,45 MHz Yogyakarta'. Brochure, Swaragama, Yogyakarta.

Syah, Sirikit

$2000 \quad$ 'Tokoh pers 1999; Media watch', Kompas, 6 January.

http://www.kompas.com/kompas-cetak/0001/06/opini/toko04.htm

Tabing, Louie N. (accessed 20-12-2005).

2000 'Bagian keempat; Radio swadaya masyarakat, bentuk baru komunikasi di Asia', in: Hinca I.P. Pandjaitan, C.C. Chan, L.S. Schramm and L.N. Tabing (eds), Radio; Pagar hidup otonomi daerah, pp. 127-38. Jakarta: Internews Indonesia Media Law Department.

Teeuw, A.

1994 Modern Indonesian literature. Vol. 1. Fourth edition. Leiden: KITLV Press. [Translation Series 10; Originally published under the same title. The Hague: Nijhoff, 1967.]

Tobing, Sumita

1991 Development journalism in Indonesia; Content analysis of government television news. PhD thesis, Ohio University. Athens, $\mathrm{OH}$.

Undang-Undang

$1998 \quad$ Undang-Undang Republik Indonesia Nomor 9 Tahun 1998 tentang Kemerdekaan Menyampaikan Pendapat di Muka Umum. Legislative document, Government of Indonesia, Jakarta.

$2002 \quad$ Undang-Undang Republik Indonesia Nomor 32 Tahun 2002 tentang Penyiaran. Legislative document, Government of Indonesia, Jakarta.

Vatikiotis, Michael R.J.

1993 Indonesian politics under Suharto; Order, development and pressure for change. London/New York: Routledge. [Politics in Asia series.]

Warren, Carol

$1994 \quad$ Centre and periphery in Indonesia; Environment, politics and human rights in the regional press (Bali). Murdoch: Asia Research Centre at Murdoch University. [Working paper 42.] 
'Tanah Lot; The cultural and environmental politics of resort development in Bali', in: Philip Hirsch and Carol Warren (eds), The politics of environment in Southeast Asia; Resources and resistance, pp. 229-61. Lon-

Weintraub, Andrew don/New York: Routledge.

2001

'Contest-ing culture; Sundanese wayang golek purwa competitions in New Order Indonesia', Asian Theatre Journal 18:87-104.

2004 Power plays; Wayang golek puppet theatre of West Java. Athens, OH: Ohio University Research in International Studies. [Southeast Asia Series 110.]

Wild, Colin

'Indonesia; A nation and its broadcasters', Indonesia Circle 43:15-40.

1991

'The radio midwife; Some thoughts on the role of broadcasting during the Indonesian struggle for independence', Indonesia Circle 55:34-42.

Witoelar, Wimar

1997 'Lessons from "Perspektif"', in: Bhimanto Suwastoyo (ed.), Broadcasting in Asia, pp. 155-60. [Jakarta]: Alliance of Independent Journalists and Institute for the Studies on Free Flow of Information.

Witte, René

1998 De Indische radio-omroep; Overheidsbeleid en ontwikkeling, 1923-1942. Hilversum: Verloren.

Wolters, Willem

2002

'The making of civil society in historical perspective', in: Henk Schulte Nordholt and Irwan Abdullah (eds), Indonesia in search of transition, pp. 131-48. Yogyakarta: Pustaka Pelajar.

Yampolsky, Philip

1995 'Forces for change in the regional performing arts of Indonesia', Bijdragen tot de Taal-, Land-en Volkenkunde 151:700-25.

Zimmer, Benjamin G.

1998

'The New dis-Order; Parodic plésétan and the 'slipping' of the Soeharto regime', Antara Kita; Bulletin of the Indonesian Studies Committee of the Association for Asian Studies 54(July):4-9.

\section{Personal communications}

Arya Dikara (I Gusti Ngurah Dibia), Tabanan, 10-7-2002.

Billy M. Sobirin, Jakarta, 3-10-2001.

Dani, Yogyakarta, 29-8-2001.

Darpan A. Winangun, Jakarta, 10-10-2001.

Errol Jonathans, Surabaya, 24-7-2002.

Firqie Firmansyah, Jakarta, 15-8-2002.

Fred Wibowo, Yogyakarta, 31-8-2001.

Idham Hamid, Padang, 20-8-2002.

Ido Seno, Jakarta, 12-10-2001.

Kecuk Sahana, Yogyakarta, 30-8-2001.

Layla S. Mirza, Bandung, 28-9-2001. 
Louis C. Schramm, Jakarta, 18-9-2001.

Masduki, Yogyakarta, 4-9-2001.

Meinara Iman D., Surabaya, 24-7-2002.

Mustawar Lubis, Padang, 20-8-2002.

Nor Pud Binarto, Jakarta, 11-8-2001.

Santoso, Jakarta, 18-10-2001.

Surowo Haryono, Yogyakarta, 2-8-2002.

Taye Tayudin Dj., Bandung, 27-9-2001.

Veven Sp. Wardhana, Jakarta, 18-10-2001.

Wibowo, Yogyakarta, 31-8-2001.

Yuga, Yogyakarta, 3-9-2001.

Yusirwan Yusuf, Padang, 19-8-2002.

Audio sources

Global FM

2002a 'Global terkini', Tabanan, 11-7-2002.

2002b Jingle 'Bali terkini', Tabanan, 11-7-2002.

2002c Jingle 'Global FM', Tabanan, 10-7-2002.

2002d Jingle 'Global FM', Tabanan, 11-7-2002.

IMLPC, Indonesia Media Law and Policy Centre

2001a 'Mengawal kebebasan pers; Bagaimana mengenali wartawan dengan benar', Jakarta, August 2001.

2001b 'Mengawal kebebasan pers; Kekerasan terhadap media massa oleh massa', Jakarta, June 2001.

2001c 'Mengawal kebebasan pers; Siapa yang bertanggung jawab dalam sebuah talk show', Jakarta, June 2001.

Jakarta News FM

2001a 'Features sang guru', Jakarta, 15-9-2001.

2001b Jingle 'Jakarta News FM', Jakarta, 16-10-2001.

2001c 'Ngobrol sama Dono', Jakarta. [weekly episodes 2001.]

2001d 'Sabtu bersama Ratna', Jakarta, 20-10-2001.

KBR 68H, Kantor Berita Radio 68H

2000 'MPR tetap pertahankan TNI/Polri hingga 2009'. Mini-feature for FNS

'Radio awards 2000'.

2001 'Hak asasi manusia', Jakarta, 9-10-2001.

2002a Jingle 'Agama dan toleransi', Jakarta, 14-8-2002.

2002b Jingle 'Kabar baru', Jakarta, 14-8-2002.

Mora

2001a Jingle 'Mora', Bandung. [daily episodes 2001.]

2001b 'Kasasi', Bandung, 29-9-2001.

2001c 'Mora interaktif', Bandung, 27-9-2001. 
2001d 'Saksi', Bandung, 29-9-2001.

2001e 'Somasi', Bandung, 4-10-2001.

Radio $68 \mathrm{H}$

2002

'Sikap redaksi Radio Berita 68H', Jakarta, 14-8-2002.

SCFM

2002a

Jingle 'Dunia bisnis Indonesia', Surabaya, 25-7-2002.

$2002 b$

Jingle 'Thank God it's Friday', Surabaya, 26-7-2002.

Suara Padang

2002a

Jingle 'Kabar baru', Padang. [daily episodes 2002.]

$2002 b$

Jingle 'Suara Padang', Padang. [daily episodes 2002.]

Suara Surabaya

$2002 a$

'Kelana kota', Surabaya, 23-7-2002.

$2002 b$

'Lembaga konsumen media', Surabaya, 23-7-2002.

Trijaya

2001a

'Jakarta first channel', Jakarta, 16-10-2001.

$2001 b$

'Thank God it's Friday', Jakarta, 19-10-2001. 



\section{Index}

Abdallah, Udin Apsar 64

Abdurrahman, Muslim 63-4

Accountability Report 95-6

Aceh 59

activity $3,6,14,28,30,39,78,83,97$, $125,129,136$

actor(s) 5-7, 10, 21, 28, 43, 77, 79, 97, 135,

153,155

aestheticization of politics 2, 51, 92, 146

Afghanistan, Afghan 41, 63-4, 83-9, 100-1

AFP 103

Africa 69, 142

'Agama dan toleransi' 64

ajeg Bali 98, 109-11, 122

AJI see Aliansi Jurnalis Independen

Ajidarma, Seno Gumira 1-2, 7, 20

Alam, Anton Bachrul 101-2

Aliansi Jurnalis Independen (AJI) 43, 46,

$56,71,152$

alienation see Verfremdung

AMARC see World Association of

Community Radio Broadcasters

America(n) see United States

Anderson, Benedict 16-7, 141, 163

Anggoro, Kusnanto 91

Angkatan 194519

Angkringan 147

Angkringan, Radio Angkringan 147,

149, 153, 162-3

Ansah, Paul 51

Antara 103

Anwar, Dewi Fortuna 91

Apartheid 142

APEC see Asia-Pacific Economic

Cooperation
Arab(ic) 29, 91

Arena 153-4

Aristotelean 155

Arps, Ben 78

Artawa, I Gusti Ngurah 136

Asia(n) 27, 39, 50, 69, 121, 142

Asia-Pacific Economic Cooperation (APEC) 86

audience(s) 3, 5-7, 10, 13, 15-6, 23, 26, 31, $39-40,56,67,72-3,75-81,83,89,95-7$,

101-2, 105-6, 111, 113-4, 118, 122-4, 127, 130, 142, 144-5, 151, 154-6, 160, 162

audience participation, audience participation programme(s) 43, 45, 79-80, 96, $102,104,144,160$

aura $7,11,144-5,147,156-7$

auratic, auratic mode 144-7, 157

Auslander, Philip 145, 156-7

Australia 39, 91, 121

authenticity, authentic 75, 89, 95, 125,

$131,144-5,157-8$

authoritative discourse 22-3

Ayu, Djenar Maesa 21-2

Bachri, Sutardji Calzoum 19

Badan Pusat Statistik 10

bahasa Betawi 16

Bahasa dan kekuasaan 15, 17

bahasa gaul 83

bahasa Jakarta 16

bahasa prokem 16-7

Bakhtin, Bakhtinian 2-3, 5-7, 9, 14-5, 18, 21-2, 49, 76, 84, 98, 102, 128-9, 134, 143, 160-1

Balai Budaya Minomartani 154 
Bali, Balinese, Balineseness 4-7, 20, 98, 109-11, 121-7, 129, 131-3, 138-9

Bali Post 110-1, 121-3, 125, 129, 134

Bali Post (Media) Group 109, 111, 121-5, 129

'Bali terkini' 109, 122-6

Bali Travel News 121

Bali TV 121-2

Bandung 7, 12, 20, 33, 46, 55-6, 59, 75,

78, 81-4, 111-5, 117

Bangkok 50

Banyuwangi 78

Barker, Joshua 136

Basri, Faizal 91

Batak 111

Bataviaasche Radio Vereeniging (BRV) 11

BBC see Britisch Broadcast Corporation

Benjamin, Walter, Benjaminian 142, 1447, 155-8

Besakih 121

Bimantara 39, 98

Bin Laden, Osama 63-4, 86-8

Binarto, Nor Pud 82-3, 104

Bisnis Bali 121

Boal, Augusto 153

Bodden, Michael 153

Bolivia 142

Bosnia-Herzegovina 57

bourgeois, bourgeois public sphere, bourgeoisness 3, 6, 29-31, 42, 45, 67-8, $80,93,100,132,135,160-1$

Bram 126-7

Brazilian 153

Brecht, Bertolt, Brechtian 7, 142, 153-6, 158

British Broadcast Corporation (BBC) 13, 55, 87-8, 107, 152

Broadcasting Law, Undang-Undang

Penyiaran 12, 32, 34-7, 123, 141

BRV see Bataviaasche Radio Vereeniging

Budiman, Andi 63-4

Buku panduan radio komunitas 142

bulletin(s) 2, 7, 12, 16, 46, 50, 52, 57, 59$60,62,74-5,78,92,98-9,104,107,118$, 163

Buraq 85
Cable News Network (CNN) 104

Calhoun, Craig 26, 29

campus radio $146,149-51$

Canada, Canadian 54, 153

capitalism 30, 40, 50, 69, 163

carnival, carnivalesque 2, 5, 9, 18, 20-1, 49

censorship, self-censorship 1-3, 20, 28, 43,53

Central Java 73, 90, 112, 146-7, 151

Central Telegraph Office 12

Centre for the Production of Educational

Catechism Media 153-4

chair of (a) debate 82

Charles 144

Christianity, Christian(s) 151, 153, 163

Citizen Band Radio 136

citizen(s) 27, 29-31, 36, 63, 69, 79-80, 84,

96, 106-7, 113, 123

citizenship 28, 31, 97-8, 109

'Citra Bali' 109, 122-4

civil, civilian(s) 11, 23, 27-9, 63, 86, 107, 135, 143, 150, 159

civil society $5,14,20,22,27-30,38,49$,

$54,61,67,69,101-2,133,137,143,159$

classical debate 79-80, 99

CNN see Cable News Network

Colombia 142

Combine Resource Institution (CRI) 146, 149

commercial(ly), commercialism 2-3, 6-7, 12-3, 22, 25, 31-3, 38-9, 41, 45, 50, 53-5, 57, 59-60, 65-6, 69, 71-2, 74-5, 78, 80-1, 83, 89, 91-2, 98-100, 103-4, 109, 111, $114,121,133,136,141,143,147,150-2$, $156-8,160,162$

community, communities, communal $18,27,33-4,45,52,56-7,59,61,63,79$, $81-2,97,109,133,141-7,149-58,162-3$ community radio $7,12,39,136,139,141$ 4, 146-50, 152-62 Community radio handbook 142 competition(s) see contest(s) consoler, consoler-therapist 82-3, 85 contest(s), competition(s) 49, 52, 68-9, 71-4, 80, 103-4, 121, 126, 132-3, 161-2 Cook, Timothy 31 cosmopatriotism 67 
Creese, Helen 109-10

CRI see Combine Resource Institution critical, critical debate, critical mode 2 , 29-31, 42, 45-6, 51, 54, 56, 59, 61-2, 85, $88,96,102,106,131-2,136,144,146$, 152,160

current affairs $6,12-3,38-9,52,55,57$, 59, 78-9, 93, 99, 104, 114-5, 121-2, 124, 139,163

\section{Dani 152}

Das Kunstwerk im Zeitalter seiner technischen Reproduzierbarkeit 144

Dayan, D. $144-5$

Deleuze, G. 20

democracy, democracies, democratic 3 , 9, 27-8, 32, 38, 53, 61, 69, 74, 86-7, 97, $102,121-2,135,142-3,158$

Demokrasi dan civil society 27

Denny J.A. 91

Den Post 121-4, 134

Denpasar 33, 110, 121, 129

Department of Agriculture 52

Department of Communications and Informatics 36

Department of Finance 32

Department of Information, Ministry of Information, Departemen Penerangan $32,36,53,114$

Department of Radio, Television and Film 52

Department of Religion 101

Depok 26, 105

Depok School 25-7, 29, 34, 36, 38, 158

Derks, Will 20

DeTik 55-6

De Tocqueville, A. 29

Deutsche Welle 13, 55, 69, 103

development journalism 2, 6, 49-53, 55$6,61,68,159$

dewan pengawas 32, 34, 159, 161

Dewan Pers 36, 65

'Dewan pers menjawab' 65

Dewan Perwakilan Rakya, (DPR) 34, 74, 131

dialogism 3, 5-6, 9, 20, 22-3, 47, 52, 100, 102,160

dialogue(s), dialogic, dialogical(ly) 3-7,
$15,19,22,45,49,52,68-9,72,76,80$, $83-5,88,92-3,96,98,102,112-3,115$, $118,123,126,128-9,131,134-5,137$, $143,154-5,159-61$

Diana 144

Dirgantara 117

Donahue 89

'Dongeng plesetan' 1-2, 20, 78

DPR see Dewan Perwakilan Rakya

DPRD, DPR-D 96, 110, 139

'Dunia bisnis Indonesia' 89

Dutch 12-4, 17, 77, 103, 112

Dutch Government 57

East Bali 137

East Java 7, 63, 78

Eastern Europe 29, 144

Eastern Indonesia 72

Eastern Lesser Sunda Islands 90

Editor 55-6

editor(s) 6, 56-7, 79, 82, 92, 95, 111, 124

editorial(s) 7, 95-6, 143

Egyptian 163

El Shinta $78,81-2$

Ema 93

England, English 12, 29-30, 39, 64, 73, 86-7, 92-4, 110-2, 121, 137-8

envelope journalism 159, see also wartawan amplop

Europe, European 26, 29-30, 69, 91, 142, 144, 155

everyday, everyday mode $5,14,16,18$, 21, 79-80, 144, 146-7

expert(s) 6-7, 25, 40, 65-6, 68, 79-80, 82, $85,89,91-2,98-9,104,107,114-5,121$, $123,126-7,131,139,160-1$

externalization of (the) inner life 30,38 , $42,67,78,162$

Fahmi, Umar 89-91

Fals, Iwan 106

fascism 146, 155

feature(s), mini-feature $7,10-11,37,57$, 60, 65, 71, 74-5, 77, 104-5, 161

'Features sang guru' 105-6, 143, 160

Federal Republic of Germany 69

Federal Republic of Yugoslavia 57

FNS see Friedrich Naumann Stiftung 
FORAKI see Forum Radio Kampus Indonesia

Ford Foundation 57

Forum Bali Peduli 138

Forum Radio Kampus Indonesia (FORAKI) 149

Fourth Branch see Fourth Estate

Fourth Estate, Fourth Branch 31, 95-6, 120, 159

FPI see Front Pembela Islam

France 30, 103

Frankfurter Schule 26, 31, 51, 142

Free Democratic Party 69

Freire, Paolo 153

Friedrich Naumann Stiftung (FNS) 13, 49, 52, 56, 68-75, 133, 161

Front Pembela Islam (FPI) 85-6, 100-2

Gadjah Mada University 150-1

Galeri Lontar 57

gatekeeper(s) 79, 82, 91-3, 95

Gazali, Effendi 25-6

Genta Bali 121-3

Germany, German 30, 55, 69, 103, 153

Gianyar 127, 139

Gilimanuk 127

'Giliran anda' 129

Global FM 4, 6, 52, 81-2, 98, 103, 107, $109,111,121-39,143,161-3$

'Global terkini' 122, 126-7, 129, 131-2, 143

Global TV 37

Government Regulation(s) 32, 34

grassroots theatre 153-4

Great Britain, British 51, 89

Guatarri, F. 20

Guided Democracy 28

Habermas, Jürgen, Habermasian 3, 6, 25-6, 29-32, 38, 42-3, 45, 59, 67-8, 78, 80, $84,91,98,100,114,131-2,135,142,146$, $158,160-1$

'Hak asasi manusia' 60, 63, 68

hak jawab 47, 67

hak koreksi 67

hak tolak 47

Harkrisnowo, Harkristuti 91

Heryanto, Ariel 19-20 heteroglossia 5, 9, 14-5, 17, 20, 49

Heuss, Theodor 69

Hidayat, Dedy 25

Hikam, Muhammad A.S. 27-9

Hilversum 55

Himpunan Praktisi Penyiaran Indonesia (HPPI) 46

Hindu, Hinduism 110, 122, 152

HIV/Aids 119-20

Hooker, Virginia Matheson 15

Hoso Kyoku 12

host(s) 6-7, 54-5, 62-4, 68, 73, 75, 77, 7994, 98-9, 102, 105, 107, 111-21, 124-9, $131,134,146,161$

HPPI see Himpunan Praktisi Penyiaran Indonesia

Human Rights Law 66

Hussein, Saddam 137

ideological becoming, ideological awareness, ideologically aware 3, 5-7, 9, $22-3,68,76,85,88,102,129,134,137$, 143,155

Iman, Meinara 119

IMLPC see Indonesia Media Law and Policy Centre

immediacy 31, 75-6, 145, 156-7

Independence, Independence Day 11-2, 15-6

independent journalism 47, 57, 60-2, 69, 159

Indies see Netherlands East Indies

'Indonesia first channel' 99

Indonesia Media Law and Policy Centre (IMLPC) 49, 56, 65, 67-8, 71, 100-1, $118,120,158,160$

Indonesian Broadcasting Commission, Komisi Penyiaran Indonesia (KPI) 25, 34-8, 159, 161

Indonesian Journalists Code of Ethics 46

Indosiar 37, 100

Indrianto, M. 149

infotainment 33, 46, 115

'Inohong di Bojongrangkong' 1-2

insert(s), sisipan 46, 65, 68, 73-6, 105, 125

Insist 149

Institut Seni Indonesia (ISI) 152, 156

Institut Studi Arus Informasi (ISAI) 55, 
57, 149

interactivity, interactive(ly) 6, 11, 33, 40, 45-7, 52, 63-4, 69, 76-9, 81, 83, 86, 89, $92,97-8,102-3,111,114-5,118,121-6$, $132-6,143,155,158,160$

Internews 13, 27, 39, 49, 56-7, 59-61, 65, $67-8,71,152-3,160,162$

'Interupsi' 91

interview(s) 7, 46, 55, 59, 63, 71, 75, 78, 81, 91-2, 100-2, 104-6, 127, 133-5, 137, 160

Iran 57

Iraq 137, 163

ISAI see Institut Studi Arus Informasi

ISI see Institut Seni Indonesia

Islam(ic) 29, 40-1, 63-4, 85-6, 100, 102, 151

Ismail, Armin 93

Israel 57

Israk Mikraj 85

Jakarta(n) 7, 12, 17, 26, 33, 39-40, 55, 57, 59-62, 64-5, 68, 73, 78, 81-3, 95-6, 98$101,104-6,111,146,163$

'Jakarta first channel' $82,99-100,160-1$

Jakarta News FM 78, 80, 82, 85, 97, 1047,111

Jakfar, Maftuhah 21

'Jam rumah tangga' 52

Japanese 12, 163

Java, Javanese 14, 16, 55, 72, 111, 127, $131,151,154$

Javanization, Javanized 16

'Jendela' 109

Jerusalem 85

jingle(s) 39-40, 59, 64, 75, 89, 92, 106, 109, 124-5, 131

Jonathans, Errol 45-6, 71-2, 94-5, 104, 107-8

Juanda 91

'Jumpa pendengar' 126, 129-32, 161

'Jurnal radio' 55-6

'Kabar Baru' 59-60

Kalimantan 61, 72

Kamper 111

Kantor Berita Radio 68H (KBR 68H) 39$40,49,56-61,63-5,67-8,71,74,95,152-$
3, 160, 162-3

'Kasasi' 115-6

Katz, E. 144-5

KBR $68 \mathrm{H}$ see Kantor Berita Radio $68 \mathrm{H}$

Kebebasan pers dan kode etik jurnalistik 46

Kediri 63

'Kelana kota' 93, 107, 143, 160

Kelompok Pendengar, Pembaca dan

Pemirsa, Kelompencapir 52, 71

Kennedy, J.F. 144

'Kesusastraan, pasemon' 17

Ketapang 127

Ketika jurnalisme dibungkam sastra harus bicara 1

Kidd, Ross 153

Kilroy 89

Kitley, Philip 15, 51-2

KKB see Koperasi Krama Bali

KKN 9

Klaten 147, 149

Komisi Penyelidik Kekayaan Pejabat

Negara (KPKPN) 95

Komisi Penyiaran Indonesia (KPI) see

Indonesian Broadcasting Commission

Komunitas Televisi Publik Indonesia (KTVPI) 27, 36

Komunitas Utan Kayu, Utan Kayu

Community 57, 68

Koperasi Krama Bali (KKB) 110

Koran 41

KPI see Komisi Penyiaran Indonesia

KPKPN see Komisi Penyelidik Kekayaan

Pejabat Negara

krama, kramanization $16-7$

Kristiadi, J. 91

KTVPI see Komunitas Televisi Publik Indonesia

Kuta Galeria 131

Lembaga Konsumen Media (LKM) 98, 118

'Lembaga Konsumen Media' 118, 120, 160-1

Lembaga Konsumen Pers (LKP) 118

Lembaga Penelitian, Pendidikan dan Penerbitan Yogyakarta (LP3Y) 27, 36

Lembaga Produksi Siaran (LPS) 55-6

Lembaga Studi Pers dan Pembangunan 
(LSPP) 61-2

Lindsay, Jennifer 77

listener(s) 6, 11, 32, 45, 52, 83-7, 89, 92-4, 106, 109, 111-7, 119, 124-8, 131-3, 136-7, 143,155

live, liveness $7,38,46,64,75-6,93,100$, $124,144-5,156-7$

lively, liveliness 73-6, 105, 118

Livingstone, Sonia 79-80, 89, 132

LKM see Lembaga Konsumen Media

LKP see Lembaga Konsumen Pers

Lomba Program Radio 69

London 55, 106-7

Los Angeles 152

LPS see Lembaga Produksi Siaran

LSPP see Lembaga Studi Pers dan

Pembangunan

Lubis, Mochtar 51

Lunt, Peter 79-80, 89, 132

Madjid, Nurcholis 29

Maier, Henk 14, 17

Majelis Permusyawaratan Masyarakat (MPR) 74

Makassar 39

Mako, Kadek 127-8, 134-5, 138

Malay, Malayness 14, 41, 83, 111

Malaysia 54

Mallarangeng, Andi 91

Mallarangeng, Rizal 91

Manado 59

Mandarin 37, 111

Manila 50

Mara 13, 55, 78, 82, 92, 114

'Masail islamiyah' 40

Masdha 151-2

Masduki 43-7, 74-5, 105

mass media $18-9,29,31,65,67,114$

$119,142-5,155,161$

masyarakat madani 29, 102

masyarakat sipil 29

masyarakat warga/kewargaan 29

Mecca 85

Medan 39

Media Development Loan Fund 57 media event(s) 144-6, 157

media literacy, media literate 3, 5-6, 65,

$68,76,80,97-8,111,118,120,160,162$ mediation 7, 75, 155, 158

Megawati 86

Menayang, Victor 25, 36

'Mengawal kebebasan pers' 65, 68, 160-1

Mercurius Top 39

meta-journalism, meta-journalistic $1-2$, $47,65,69,120,124,159-60$

Metro Jaya, Metro Jaya Regional Police 73, 101

Metro TV 66, 100-2

Middleton, Richard 144, 147, 152, 155

'Mimbar demokrasi' 38

Minang 111

Minister of Communications and Informatics 34, 36

Minister of Defence 74

Minister of Information 12, 55-6

Minister of Research and Technology 29

Ministerial Decree 12-3

Ministry of Information see Department of Information

Mirza, Layla S. 114

mode(s) of address 81-2

Mohamad, Goenawan 17-9, 57

Mohammad 85

Moluccas 61-2, 160

monologism 3, 5, 9, 14-7, 22-3, 49, 52, 76, $133,159-60$

monologue, monologic(al) 6, 33, 45, 47, $53,55,61,68,75,85,97,99,128$

Mora 39, 75, 80-5, 98, 111-2, 114-8, 161

'Mora interaktif' 83, 88, 115

MPR see Majelis Permusyawaratan Masyarakat

'MPR tetap pertahankan TNI/Polri hingga $2009^{\prime} 74$

MsTri 65

multi-sided journalism 6, 97-9, 102, 160-1

multi-sidedness 97, 102

Mulyani, Sri 91

Muslim 29, 63-4, 86

'Mutiara hikmah' 40

mycelium 20

Nadha, Ketut 122

Naradha, A.B.G. Satria 122

Naumann, Friedrich 69 
Netherlands, the 55

Netherlands East Indies (Indies) 11-2, 14

New Order 1-3, 5-6, 9, 12-8, 20-3, 25-8, $33,36,43,45-7,49-50,52-4,56,59,61-2$, 66-8, 71-2, 74-7, 79, 85, 98-9, 102-3, 107, $114,120,128,133,152-3,158-9,162$

New World Information and Communication Order (NWICO) 501, 53

New York 96

New Zealand 121

'Ngobrol sama Dono' 82-3, 104

NGO(s) 6, 25-8, 38, 45-7, 61-2, 67, 71, $146,149,152,162$

ngoko 16

nickname(s) 136-7

North America 69

North Atlantic 163

North Sulawesi 59

North Sumatra(n) 54, 111

North Surabaya 93

nostalgia, nostalgic $7,144,147,150$, 156-7

Noya, Andi F. 101-2

Nugroho, Garin 27

NWICO see New World Information and Communication Order

Old Order 12, 18, 153

Olympic Games 144

oppositional, oppositional public sphere $6,9,80,100,132,145,160-1$

Pabottinggi, Mochtar 17

Padang 7, 33-4, 40-1, 59, 68, 81-2

Padjadjaran University 115

Palapa 54, 61

Palestine 57, 63

Pancasila 53

Pandjaitan, Hinca I.P. 65-7, 120

Papua 38, 59

parliament(s), Parliament, parliamentary, parliamentarians 27-8, 34, 36, 56, 65, $69,71,73,95-6,100,103,110,123,129$, 139, 151

Partai Demokrasi Indonesia (PDI-P) 74, 138-9

Partai Demokrat (PD) 38 pasemon 17-20, 159

PD see Partai Demokrat

PDI-P see Partai Demokrasi Indonesia

peace journalism, peace journalists 47 , 57, 61-4, 69, 83, 96, 159

Pembangunan 50

People Power 153

Persatuan Radio Siaran Swasta Nasional Indonesia (PRSSNI) 53, 55, 71

Persatuan Wartawan Indonesia (PWI) $46,53,56$

persuasive discourse 22, 129

PFA see Press Foundation of Asia

phatic performance $42,78-9$

Philippine(s) 27, 152-3

Pipud 93

Pitaloka, Rieke Diah 21

plesetan 17, 19-20, 83, 85, 128, 159

Polisi Republik Indonesia (POLRI) 74

POLRI see Polisi Republik Indonesia

polyglossia $14-5$

Pop Sunda 1-2

Prapanca 39

Prasodjo, Imam B. 91

Press Foundation of Asia (PFA) 50, 53, 56

press freedom $3,43,46,65,102,160-1$

Press Law 46-7, 66

Priyanto, Agus Bambang 135

propaganda 2, 51, 54, 107, 145, 155, 158

Propaganda and Information

Department 12

PRSSNI see Persatuan Radio Siaran

Swasta Nasional Indonesia

PTPN 73

public sphere $3-6,10,25-31,38,42,45$, $49,56,61,67-8,80,93,98,100,114,118$, $132,135,146,159-62$

publicness $3,6,25,32,35-6,38,80,93$,

98, 114, 116, 119, 161

Pusat Pengembangan Masyarakat

(PUSKAT) 154

PUSKAT see Pusat Pengembangan

Masyarakat

PWI see Persatuan Wartawan Indonesia

Quadrant News Centre 73 
Rabinow, Paul 163

Rachbini, Didik J. 91

Radio 68H 57, 95

Radio Australia 13, 55

Radio Besakih 121, 123

radio journalism, radio journalist(s) 3 , 5-6, 9, 12-4, 22-3, 25, 43-7, 49, 55, 69, 71-4, 76-8, 94, 96, 114, 121, 124, 132, 161-3

radio ketimuran 13,77

radio komunitas see community radio radio liar 153

Radio Nederland 13, 55, 107, 153

Radio Republik Indonesia (RRI) 3, 12-3, 16, 25-6, 32-5, 49-50, 52, 55, 57, 59, 74, $78,149,152-3,158-9$

Radio Soreram Indah (RSI) 111

Radio Vatican 153

Rahardjo, Dawam 29

rational, rational debate $26,29,31,42$, $67,79-80,84,88,92-3,96,99,131,160-1$ RCTI 91, 98

refeudalization, refeudalized $6,30-1,38$, $67,80,91,98,114,118,141,146,161$

Reformasi 2-3, 5-6, 9-15, 20-2, 25, 27, 33, 43, 45-6, 49, 53, 56-7, 60-2, 65-7, 69, 72, 74-5, 80, 83, 96, 100-2, 104, 106-7, 120-1, 124-5, 131, 133, 135, 137, 139, 151, 159, 162

refunctioning see Umfunktionierung regional autonomy $11,27,33,35,38,60$, 67, 71-2, 78, 107, 109, 111, 151

regional awareness $6,97,106,109$

Rendra 19

reportage $71,73,97,104-5,129$

reporter(s) 6-7, 40, 62, 73, 75, 79, 100-1, 105-6, 115, 121

Restu 93-4

Ria FM 73

Riau 111

Riau TV 111

Robins, Bruce 162-3

Rockefeller Financial Services 57

Romano, Angela 43, 46

romantic narrative $79-80$

RRI see Radio Republik Indonesia

RSI see Radio Soreram Indah

Rumah Bersama 105-6, 143
'Sabtu bersama Ratna' 85, 88, 100, 104

'Saksi' 112, 115

Salim, Emil 91

Sanata Dharma University 152

Santec 153

Sapura, Ipung 137

SARA 53, 107, 133

Saragih, Monang 114-8

Saraswati 151-3

Sarumpaet, Ratna 82, 85-8

SCFM 39-40, 82, 89

SCTV 37, 92

SD Negeri Cipayung 105

Second World War 12

segmentation, segment(s) 6, 13-4, 25, 38$42,67,77,111,114,162$

'Sehat Indonesiaku' 60, 67

Seligman, Adam 27-8, 42

Semarang 39

Sen, Krishna 77

Seno, Ido 99

Shanghai 86

Shihab, Habib Risieq 100-2

Shinta 78

'Siaran pedesaan' 52

Sidotopo 93

Siegel, James 16, 133

'Sikap redaksi Radio Berita 68H' 95

Simanjuntak, Panusunan 55

Sinduharjo 154

Singaga, Kastorius 91

Singapore 54

Singaraja 121

Singaraja FM 121, 123

Siregar, Ashadi 27, 36

Siregar, Liston 55

sisipan see insert(s)

SIUPP see Surat Izin Penerbitan Usaha

Pers

Sjahrir 91

Social empowerment personality(ies),

Tokoh pemberdayaan masyarakat 121 ,

126-7, 132-4, 136-7, 161-2

Socrates di radio 45

Soekomihardjo, Soetojo 103

Soemawisastra, Billy 92

Solo, Surakarta 73, 101 
'Somasi' 112, 115

South African 142

South America 69

South-East Asia(n) 10, 28

Soviet Union 57

Spyer, Patricia 62

Stalinism 155

Stanley 93-4

star(s), star-hero 31, 82, 85-6, 91

Strassler, Karen 71-2

'Suara bangsaku' 60,67

Suara Indonesia 122

Suara Padang 40-1, 46, 59-60, 68, 81-2, 111

Suara Petani Klaten 147, 149, 153

Suara Surabaya 13, 45, 71, 78, 81-2, 92-5, 97-8, 102-4, 107-9, 118-20, 143, 160

Suarta, Putu Gede 137

Sudarsono, Yono 74

Suharto 1-3, 5-7, 9-10, 12, 15-6, 18, 20, 22-3, 25, 39, 43, 46, 53-4, 61-2, 76, 87-8, $96,98,104,109,111,118,152,158-9$, 163

Sujana 128, 131

Sukarno 12, 16, 18

Sulawesi 61,72

Sumatra 72,90

Sundanese 1, 20, 71, 78, 83-4, 111-3, 115

Sunjaya, Mohamad 55-6

Supreme Court 34, 56

Surabaya 7, 40, 78, 81-2, 89, 93, 95, 107, 109, 118

Surat Izin Penerbitan Usaha Pers (SIUPP) 53

Suryadi 111

Suryakusuma, Julia 21-2

Suryawan, I Ngurah 109-10

Sutiyoso 95

Suwarsono, Tjuk 119

Swaragama, Swara Gadjah Mada 83, 150-1

Syah, Sirikit 118

Tabanan 7, 81-2, 107, 121-2, 163

Tabing, Louie 27

Taliban 63-4, 86-8

talk show(s) 3, 6-7, 33, 37-40, 45, 54, 57, 62-6, 68, 79-80, 82-3, 85-6, 88-9, 91-3,
97-100, 102-4, 107, 111-2, 115-6, 120-6, $128,132-4,136-7,147,160-3$

talk-back 12, 77-9, 98, 114, 124, 129, 135, 159-60, 162

'Tanggapan Bali terkini' 123, 129

Teater Utan Kayu 57

Teeuw, Hans 17

Televisi Republik Indonesia (TVRI) 15-6, 26-7, 34-5, 37-8, 49-52, 65

Tempo 55-7, 134-5

Tentara Nasional Indonesi (TNI) 74

Ternate 62

'Thank God it's Friday' 40, 89, 99

The Asia Foundation 57, 61

therapy, therapeutic 79-80, 83

Timbulharjo 147, 149, 156, 163

Timor Loro Sae 57

TNI see Tentara Nasional Indonesia

Toko Buku Utan Kayu 57

Tokoh 121

Tokoh pemberdayaan masyarakat see

Social empowerment personality(ies)

TPI 37

transparency, transparent $19,27,57,62-$

$5,75-6,85,124,139,162$

Trihatmojo, Bambang 98

Trijaya 39-41, 78, 80-2, 89, 91-2, 97-100, 102,160

Tuchman, Gaye 43

TVRI see Televisi Republik Indonesia

UI see Universitas Indonesia

Umfunktionierung, refunctioning 7, 14950, 153-5

Undang-Undang Menyampaikan

Pendapat di Muka Umum 100

Undang-Undang Penyiaran see

Broadcasting Law

Undang-Undang Telekomunikasi 36

UNESCO see United Nations

Educational, Scientific and Cultural

Organization

uniqueness 144-5, 157

Unisi 13, 68, 78, 81-2, 109, 111, 152

United Nations 50, 86

United Nations Educational, Scientific and Cultural Organization (UNESCO) 50-1, 142-3, 146-7, 158 
United States (US), America(n) 26-7, 31, 37, 50-1, 54, 57, 63-4, 83-7, 89, 91, 100-1, 104, 119, 163

United States Agency for International

Development (USAID) 57, 61

United States Information Agency (USIA) 57

Universal Declaration of Human Rights 50

Universitas Indonesia (UI) 25

University of California 152

Urbaningrum, Anas 38

USAID see United States Agency for International Development

USIA see United States Information Agency

Utami, Maria Christina Sri Wiji Utami 137

Verfremdung, alienation 149, 153, 155-6

Veritas 153

virtual(ly) 3, 10, 106, 109, 162

virtual interactivity $68-9,76,159-60$

Voice of America 13, 40-1, 55

Voice of Indonesia 32

Voice of Papua 39

Wahid, Abdurrahman 29, 66

Warkop, Dono 82

wartawan amplop, envelope journalists 66 wartawan bodrek 66 wartawan gadungan 66

'Warung Bali' 122
'Warung Global' 122-3, 134-5

Watergate 144

wayang $2,71,147,154$

Weber, Max 42

Weimar 69

Weintraub, Andrew 71

West Java, West Javanese 1-2, 7, 55-6, 59, 78, 84, 90, 112, 115, 136

West Kalimantan 54

West Sumatra 7, 40-1, 90

Wibisono, Joss 55

Wibowo, Fred 154

Winfrey, Oprah 85, 89

Witoelar, Wimar 54

woman, women 13, 21-2, 52, 60-6, 110,

$116,133,137-8,163$

World Association of Community Radio

Broadcasters (AMARC) 27

World Space 39

World Trade Center (WTC) 63, 96

WTC see World Trade Center

Wijaya, Andi 119-20

Wijaya, Putu 19-20

Yayasan Sains, Estetika dan Teknologi 27

Yetti 63-4

Yogyakarta 7, 39, 78

Yosfiah, Yunus 12

youth 13-4, 16-7, 19, 33, 81, 83, 113, 119,

$134,150,153$

Yudhoyono, Susilo Bambang 38, 91 